UNIVERSIDADE DE SÃO PAULO

ESCOLA POLITÉCNICA

ANTONIO HAMILTON MICHEL MERHEB

ANÁLISE MECÂNICA DO LASTRO FERROVIÁRIO POR MEIO DE ENSAIOS TRIAXIAIS CÍCLICOS

São Paulo 


\section{ANÁLISE MECÂNICA DO LASTRO FERROVIÁRIO POR MEIO DE ENSAIOS TRIAXIAIS CÍCLICOS}

Dissertação apresentada à Escola Politécnica da Universidade de São Paulo para obtenção do título de Mestre em Engenharia

Área de concentração:

Engenharia de Transportes

Orientador: Prof $^{\mathrm{a}}$ Titular

Liedi Légi Bariani Bernucci

São Paulo 
Este exemplar foi revisado e corrigido em relação à versão original, sob responsabilidade única do autor e com a anuência de seu orientador.

São Paulo, 19 de novembro de 2014.

Assinatura do autor

Assinatura do orientador

Catalogação-na-publicação

Merheb, Antonio Hamilton Michel

Análise mecânica do lastro ferroviário por meio de ensaios triaxiais cíclicos / A.H.M. Merheb. -- versão corr. -- São Paulo, 2014.

$148 \mathrm{p}$.

Dissertação (Mestrado) - Escola Politécnica da Universidade de São Paulo. Departamento de Engenharia de Transportes.

1.Ferrovias 2.Lastro 3.Ensaios triaxiais I. Universidade de São Paulo. Escola Politécnica. Departamento de Engenharia de Transportes II.t. 
Aos meus pais,

Afonso e Sandra pelo amor, carinho e dedicação dados a mim. 


\section{AGRADECIMENTOS}

A Deus, por me dar força e coragem todos os dias.

Agradeço a todos aqueles que, de alguma forma, colaboraram com este trabalho ao longo destes dois anos, e em especial quero agradecer:

Aos meus pais, pelo amor e apoio incondicionais.

À minha querida orientadora-mãe Liedi, pela oportunidade dada e por ter acreditado em mim. Obrigado pelos valiosos ensinamentos, incentivo e ânimo em diversos momentos;

À amiga-professora Rosângela Motta, que muito contribuiu não somente para esta pesquisa, mas também para o meu aprendizado.

Ao professor Suzuki, pela serenidade de seus ensinamentos e pelas críticas e sugestões no exame de qualificação.

À professora Kamilla Vasconcelos, pelos diversos conselhos e pela amizade regada a muitas risadas ao longo de todo o mestrado.

Ao grande amigo Erasmo pela grande ajuda e diversos momentos de alegria durante os ensaios.

Ao Edson, pelo seu bom humor e carinho diários e pela ajuda no desenvolvimento desta dissertação.

À nossa secretária do LTP Diomária, aos técnicos do LTP, Cleiton, Kendi, Vanderlei e em especial ao Robson pela grande ajuda;

Aos colegas do LTP que têm sido grandes companheiros no dia-a-dia: luri, Serginho, Tiago, Igor, John, Claudio, Márcia, Kazuo, Edgar, Patricia, Matheus e Ghutier.

Ao meu irmão Daniel Pulliti que muito me incentivou e me escutou durante estes dois anos. 
Aos professores Faiçal Massad, Maria Eugênia, Jorge Nader, Marcos Massao e Fernando Marinho pelos valiosos ensinamentos que auxiliaram no desenvolvimento do meu conhecimento;

Ao professor Denilson Sodré que acreditou em mim durante a graduação e orientoume no trabalho de conclusão.

Ao grande mestre e amigo Manuel Perez que sempre está em meus pensamentos devido à amizade cultivada durante o curso de graduação na UFPA.

Ao CNPq pela bolsa de mestrado e à Vale S.A. por proporcionar condições para que esta pesquisa se realizasse. 
"O homem erudito é um descobridor de fatos que já existem, mas o homem sábio é um criador de valores que não existem e que ele faz existir". 


\section{RESUMO}

Este trabalho faz parte de uma pesquisa voltada ao estudo do comportamento mecânico do sistema ferroviário e tem foco principal no estudo experimental em laboratório que visa avaliar as características do lastro ferroviário em condições de carga variadas e determinar a influência dos principais parâmetros que afetam o comportamento da estrutura. O material utilizado em camada de lastro ferroviário é normalmente constituído de frações granulométricas graúdas o que dificulta a execução de testes de grande escala em laboratório, devido à robustez necessária do equipamento para representar a correta correspondência entre a amostra e o material de lastro. O principal objetivo deste trabalho foi avaliar a eficiência de um novo aparelho triaxial em larga escala $(400 \mathrm{~mm} \times 800 \mathrm{~mm})$, que permite ensaiar agregados graúdos como no campo sem a necessidade de escalonamento da curva granulométrica; analisar a aplicabilidade da técnica de graduação paralela em ensaios triaxiais utilizando equipamento cilíndrico de pequena escala (150mm x 300mm), no qual é mais fácil de manipular pequenas frações, assim como avaliar a influência de duas graduações diferentes sobre deterioração e deformação. Verificou-se que os materiais granulares revelam uma forte tendência de se compactar sob níveis elevados de estresse, causando um aumento significativo de rigidez. A graduação AREMA № 24 mostrou-se mais resistente à deformação e a deterioração quando comparada à AREMA № 3. O nível de tensões escolhido mostrou-se satisfatório para simular a via permanente sob carregamento, devido à deterioração dos agregados ao final do teste. Além disso, a degradação da amostra contaminada foi mais acentuada que aquela sem finos, demonstrando que o aumento no nível de colmatação implica em perda da durabilidade do lastro, acarretando em necessidade de mais ciclos de correção geométrica e diminuição de sua vida útil. Observou-se que combinação de finos e água no lastro afeta fortemente a resposta mecânica da via permanente, diminuindo sua rigidez e ocasionando instabilidade do sistema, devendo esta situação ser evitada. Os resultados também apontam que o aumento de carga por eixo contribui para uma degradação acelerada dos componentes da via, ocasionando a diminuição do período entre ciclos de manutenção. Os resultados contribuem para uma melhor compreensão do comportamento mecânico da camada de lastro, e desta forma auxiliam no projeto de vias férreas mais eficientes. 


\begin{abstract}
This work is part of a research focused on studying the mechanical behavior of the railroad system and has a primary focus on experimental laboratory work aimed to evaluate the characteristics of railway ballast under conditions of varying load and determines the influence of the main parameters that affect the behavior of the structure. Materials used in ballast layers are usually comprised of a highly coarsegraded gradation, hence the implementation of large-scale laboratory tests is difficult to conduct due to the corresponding large-scale triaxial specimens for railroad ballast material. The main purpose of this paper was to evaluate the efficiency of a new large-scale triaxial apparatus $(400 \mathrm{~mm} \times 800 \mathrm{~mm})$, that allows testing large-size particles as found in the field without the need of scaling aggregates; the applicability of the parallel gradation technique in triaxial tests using small-scale cylindrical equipment $(150 \mathrm{~mm} \times 300 \mathrm{~mm})$, in which it is easier to manipulate small fractions, as well as to assess the influence of two different gradations on ballast breakage and deformation. It was found that granular materials reveal a strong tendency to settle under higher stress levels, causing a significant increase of their strength and stiffness. The AREMA No. 24 gradation was found to be the most resistant to ballast settlement compared to AREMA No. 3. The stress level chosen was satisfactory to simulate the permanent way under load, due to deterioration of the aggregates at the end of the test. Moreover, the degradation of the contaminated sample was more pronounced than the one without fouling, demonstrating that increased level of fouling implies loss ballast durability, resulting in the need for more rounds of geometric correction and reduction of the life cycle. It was observed the combination of fines and water in the ballast strongly affects the mechanical response of the track, reducing its stiffness and causing system instability, and this situation must be avoided. The results also indicate that increasing axle load contributes to accelerated deterioration of track components, causing a decrease in the period between maintenance cycles. The results contribute to a better understanding of the mechanical behaviour of ballast layer, and thereby assist in the design of more efficient railways.
\end{abstract}




\section{LISTA DE FIGURAS}

Figura 1 - Distribuição modal da matriz brasileira de transportes de cargas em 2011 (PNLT, 2012)

Figura 2 - Evolução da extensão $(\mathrm{km})$ das malhas rodoviária e ferroviária entre 1996 e 2011 (DNIT/ANTT/GEIPOT, 2011)

Figura 3 - Custos de Logística em \% do PIB (Guasch, 2002) .21

Figura 4 - (a) Seção típica de via ferroviária convencional e (b) seção de via sobre laje de concreto (Indraratna et al., 2011).

Figura 5 - Estrutura ferroviária convencional e seus componentes (Selig e Waters, 1994)

Figura 6 - Representação da distribuição de tensões verticais entre os componentes (RailCorp, 2010)

Figura 7 - Representação esquemática da via e seu modelo analítico (Bathrust e Kerr, 1995) .36

Figura 8 - Medições das tensões de contato entre dormente e o lastro (Shenton, 1975) .38

Figura 9 - Simplificação da distribuição de tensões entre o dormente e o lastro (Jeffs e Tew, 1991). 39

Figura 10 - Representação esquemática da distribuição das células de carga na via (Indraratna et al., 2010) 39

Figura 11 - Tensões verticais e horizontais máximas medidas para: (a) trem de passageiros com $82 \mathrm{t}$; (b) trem de carga com vagões de $100 \mathrm{t}$ (Indraratna et al., 2010a) .40

Figura 12 - Tensões verticais máximas cíclicas transmitidas ao lastro pela passagem de vagões de $100 \mathrm{t}$ (Indraratna et al., 2010a). 
Figura 13 - Tensões horizontais medidas em ensaios de box tests (Selig e Waters, 1994)

Figura 14 - Distribuições granulométricas - ABNT NBR 5564 .45

Figura 15 - Distribuições granulométricas - AREMA (2009) 46

Figura 16 - Distribuições granulométricas - (a) AS 2758.7; (b) RIC e Queensland Rail (Indraratna et al., 2011) .46

Figura 17 - Distribuições granulométricas (a) EN 13450 (2002); (b) British Railways; SNCF (Profillidis, 2006)

Figura 18 - Deformações de materiais granulares durante um ciclo de aplicação de carga (Lekarp et al., 2000) .49

Figura 19 - Representação da curva tensão/deformação de um ensaio triaxial drenado de carga cíclica com material de lastro (Selig e Waters, 1994). .51

Figura 20 - Quatro tipos do comportamento elasto-plástico de materiais granulares submetidos à carga cíclica (Johnson, 1986) .52

Figura 21 - Detalhes da instalação de LVDT para medidas de deflexão (Anderson e Rose, 2008) .54

Figura 22 - Medidas de deflexão por LVDT realizada em trecho experimental nos EUA (Anderson e Rose, 2008). .54

Figura 23 - Componentes de equipamento de ensaio triaxial e estado de tensão assimétrico em um teste convencional (Suiker et al., 2005). .55

Figura 24 - Exemplos de ensaios triaxiais em grande escala com confinamento aplicado por vácuo (a) Nalsund, 2010; (b) Sevi, 2009 .58

Figura 25 - (a) Distribuições granulométricas usadas em testes triaxiais cíclicos; (b) deformação axial e volumétrica obtida em testes triaxiais cíclicos (Indraratna et al., 2004) 
Figura 26 - Comportamento deformacional de lastro contaminado por diferentes materiais em ensaios triaxiais cíclicos (a) Contaminação por material do próprio lastro (quebra) e, (b) Contaminação por minério de carvão (Ebrahimi et al., 2010) ..63

Figura 27 - Relação entre o módulo de resiliência e o estado de tensões (Selig e Waters, 1994)

Figura 28 - Ensaios triaxiais, em escala real, realizados em lastro sob carga cíclica (lonescu et al., 1998) .65

Figura 29 - Efeito da contaminação progressiva no processo de manutenção da via (Selig e Waters, 1994 modificado)

Figura 30 - (a) Defeito vertical, (b) horizontal e (c) transversal (Profillidis, 2006) .....68

Figura 31 - Coleta realizada no pátio de estocagem da Vale S.A., em Cariacica (ES)

Figura 32 - Detalhe da coleta realizada na pedreira Brasitália .72

Figura 33 - Distribuição dos ensaios, por análise proposta .73

Figura 34 - Aparato triaxial de verdadeira grandeza no LTP (a) pesagem do molde, (b) grua de transporte e bancada de ensaio, e (c) vibrador elétrico .75

Figura 35 - (a) Detalhe da colagem da membrana e (b) Detalhe da membrana mantida no molde plástico para a secagem .76

Figura 36 - Detalhes do triaxial 150×300 mm .77

Figura 37 - Ciclo de carregamento típico utilizado nos ensaios triaxiais (Indraratna et al., 2010b) .78

Figura 38 - (a) Braço de sustentação do equipamento; e (b) detalhe do posicionamento LVDT 79

Figura 39 - (a) Sinal do LVDT bruto; (b) sinal tratado pela Transformada Discreta de Fourier; (c) ciclo de carregamento baseado no sinal. .80 
Figura 40 - Homogeneização e quarteamento do material .82

Figura 41 - Curva granulométrica dos agregados coletados no pátio da Vale .83

Figura 42 - (a) Resultado do ensaio de forma dos agregados pela norma ABNT (b) Resultado do ensaio pela norma ASTM. .84

Figura 43 - Segunda amostragem de agregados (a) Resultado do ensaio de forma pela norma ABNT (b) Resultado do ensaio pela norma ASTM .86

Figura 44 - Etapas de preparação do corpo de prova de grande escala. .92

Figura 45 - Preparação da amostra decalada .92

Figura 46 - Adição de contaminação na amostra (a) escala real; (b) escala reduzida .93

Figura 47 - Resultados dos ensaios cíclicos para amostras GE I X PE I (a) Módulo de resiliência (b) Deformação permanente .95

Figura 49 - Resultados dos ensaios cíclicos para amostras contaminadas GE III X PE III (a) Módulo de resiliência (b) Deformação permanente .97

Figura 50 - Distribuições granulométricas das amostras GE I X PE I (a) escala real; (b) escala reduzida...... 100

Figura 51 - Distribuições granulométricas das amostras GE II X PE II (a) escala real; (b) escala reduzida. 100

Figura 52 - Distribuições granulométricas das amostras contaminadas GE III X PE III (a) escala real; (b) escala reduzida 100

Figura 53 - Agregados deteriorados após os ensaios mecânicos GE I e GE II 101

Figura 54 - Detalhe das amostras durante a ciclagem GE I (esquerda) e GE II (direita) 102

Figura 55 - Resultado dos ensaios GE I e GE III (a) módulo de resiliência (b) deformação permanente .104 
Figura 56 - Resultado dos ensaios PE I, PE III e PE IV (a) módulo de resiliência (b) deformação permanente 106

Figura 57 - Distribuições granulométricas das amostras GE I e GE III (a) escala real sem contaminação; (b) escala real contaminada 108

Figura 58 - Distribuições granulométricas das amostras em pequena escala (a) sem contaminação (PE I); (b) contaminada sem umidade (PE III); (c) contaminada úmida (PE IV) antes e após o ensaio 108

Figura 59 - Resultado dos ensaios GE I (AREMA 24) e GE II (AREMA 3) (a) módulo de resiliência (b) deformação permanente axial.

Figura 60 - Resultado dos ensaios PE I (AREMA 24) e PE II (AREMA 3) (a) módulo de resiliência (b) deformação permanente axial.

Figura 61 - Resultado dos ensaios PE V (AREMA 24) e PE VII (AREMA 3) de módulo de resiliência (a) escala linear (b) escala logarítmica

Figura 62 - Resultado de deformação permanente axial dos ensaios PE V (AREMA 24) e PE VII (AREMA 3) (a) escala linear (b) escala logaritmica

Figura 63 - Resultado dos ensaios PE VI (AREMA 24) e PE VIII (AREMA 3) de módulo de resiliência (a) escala linear (b) escala logarítmica 116

Figura 64 - Resultado de deformação permanente axial dos ensaios PE VI (AREMA 24) e PE VIII (AREMA 3) (a) escala linear (b) escala logarítmica 116

Figura 65 - Resultado dos ensaios PE IX (AREMA 24) e PE X (AREMA 3) (a) módulo de resiliência (b) deformação permanente axial 118

Figura 66 - Distribuições granulométricas das amostras GE I e GE II 119

Figura 67 - Distribuições granulométricas das amostras PE I e PE II 120

Figura 68 - Distribuições granulométricas das amostras PE V e PE VII 120

Figura 69 - Distribuições granulométricas das amostras PE VI e PE VIII 120 
Figura 70 - Distribuições granulométricas das amostras PE IX e PE X

Figura 71 - Resultado dos ensaios PE V (AREMA 24) e PE VI (AREMA 24) de módulo de resiliência (a) escala linear (b) escala logarítmica 123

Figura 72 - Resultado dos ensaios PE VII (AREMA 3) e PE VIII (AREMA 3) de módulo de resiliência (a) escala linear (b) escala logarítmica 123

Figura 73 - Resultado de deformação permanente axial dos ensaios PE V (AREMA 24) e PE VI (AREMA 24) (a) escala linear (b) escala logarítmica 124

Figura 74 - Resultado de deformação permanente axial dos ensaios PE VII (AREMA 3) e PE VIII (AREMA 3) (a) escala linear (b) escala logarítmica 124

Figura 75 - Distribuições granulométricas das amostras PE V e PE VI. 127

Figura 76 - Distribuições granulométricas das amostras PE VII e PE VIII. 127

Figura 77 - Envoltória às trajetórias de tensão 128

Figura 78 - Módulo de resiliência versus tensão confinante 130

Figura 79 - Módulo de resiliência versus tensão-desvio 130

Figura 80 - Distribuição granulométrica da amostra PE XI 132 


\section{LISTA DE TABELAS}

Tabela 1 - Limite de aceitabilidade para diversas propriedades do lastro AREMA (para granito) e ABNT.

Tabela 2 - Locais onde foram realizados ensaios triaxiais de grande escala em estudos de lastro

Tabela 3 - Valores limites de defeitos para intervenção e manutenção de ferrovias de alguns países (Profillidis, 2006).

Tabela 4 - Valores de emergência para defeitos de acordo com a velocidade máxima permitida (Profillidis, 2006).

Tabela 5 - Valores aceitáveis para defeitos, após execução de manutenção (Profillidis, 2006).

Tabela 6 - Detalhes de cada condição avaliada .73

Tabela 7- Valores de referência adotados para o cálculo das tensões atuantes .78

Tabela 8 - Resultado do ensaio de Abrasão Los Angeles e limites máximos por norma .89

Tabela 9 - Resumo dos resultados obtidos nos ensaios de caracterização .90

Tabela 10 - Detalhe dos corpos de prova .94

Tabela 11 - Detalhes dos ensaios para análise da contaminação 103

Tabela 12 - Detalhes dos ensaios para o estudo da granulometria. 110

Tabela 13 - Detalhes dos ensaios para o estudo da influência do carregamento ..122 Tabela 14 - Combinações de tensões aplicadas no ensaio de módulo de resiliência 129 


\section{LISTA DE ABREVIATURAS E SIGLAS}

ABNT - Associação Brasileira de Normas Técnicas

AREMA - American Railway Engineering and Maintenance-of-Way Association

ASTM - American Society for Testing and Materials

EFVM - Estrada de Ferro Vitória Minas

EPUSP - Escola Politécnica da Universidade de São Paulo

FID - Fator de incremento dinâmico

FRA - Federal Railroad Administration

GE - Grande escala

LTP - Laboratório de Tecnologia de Pavimentação

LVDT - linear variable differential transformer

MR - módulo de resiliência

MTS - Material Test System

PE - Pequena escala

PIL - Programa de Investimento em Logística

PNLT - Plano Nacional de Logística e Transporte

RIC - Rail Infrastructure Corporation

SNCF - Société Nationale des Chemins de fer Français

SPNT-MT - Secretaria de Política Nacional de Transportes do Ministério dos Transportes

TKUs - toneladas-quilômetro-úteis

UIC - International Union of Railways 


\section{SUMÁRIO}

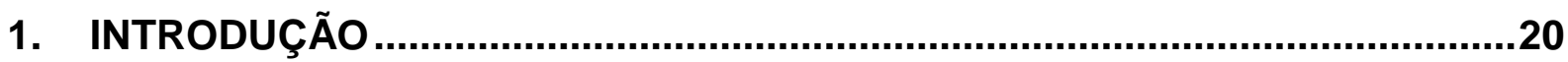

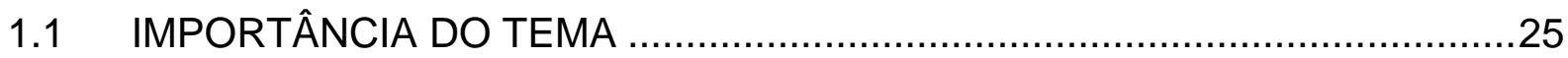

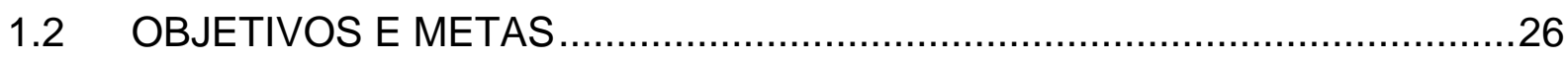

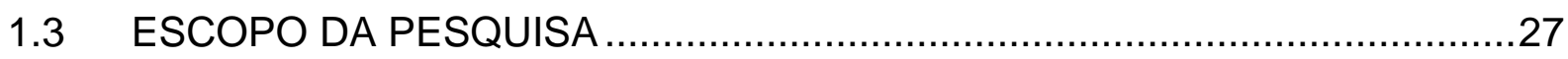

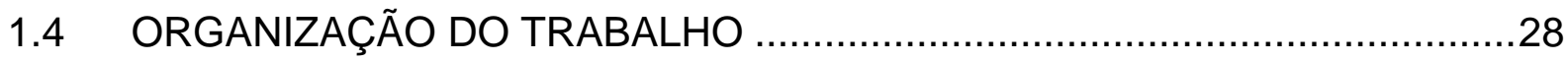

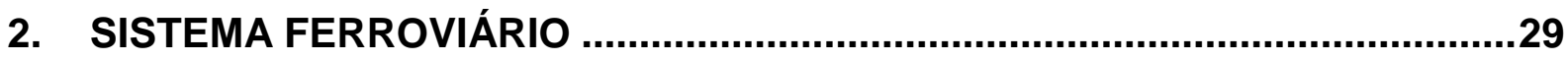

2.1 VIA CONVENCIONAL E MECANISMO DE TRANSFERÊNCIA DE

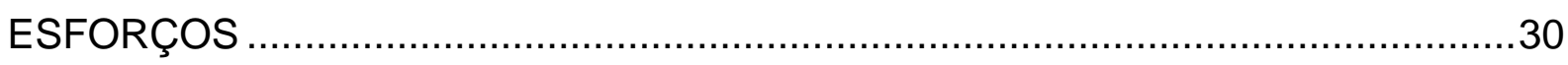

2.1.1 Estrutura

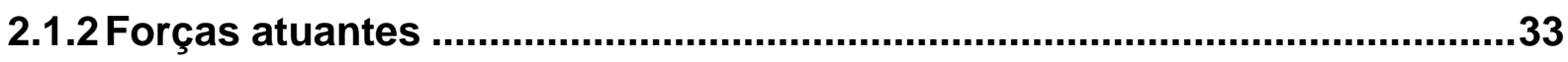

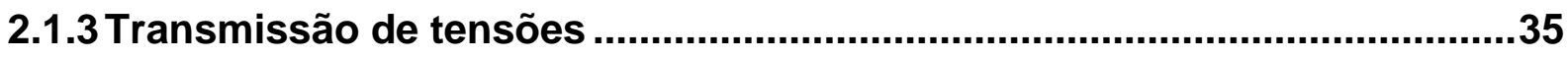

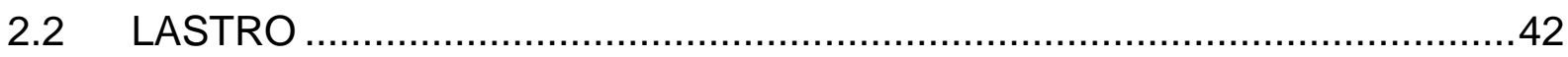

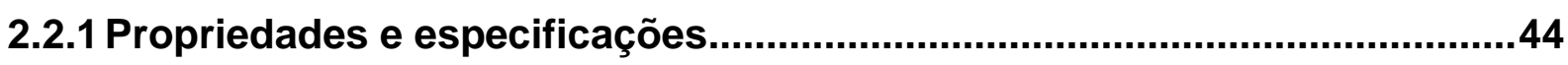

2.2.2 Comportamento Mecânico .............................................................................

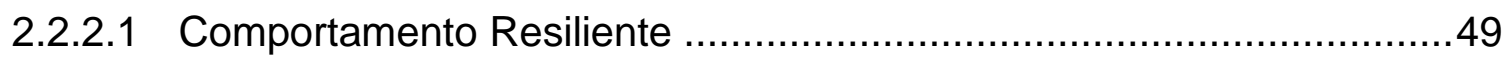

2.2.2.2 Deformação Permanente ...............................................................

2.2.2.3 Avaliação do comportamento mecânico em campo e laboratório.........53

2.2.2.4 Elementos que afetam o comportamento mecânico ............................60

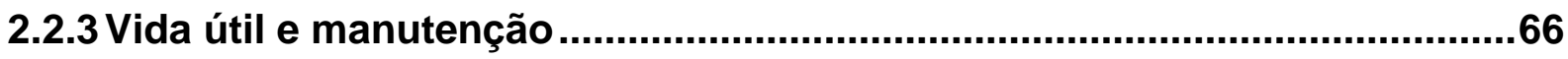

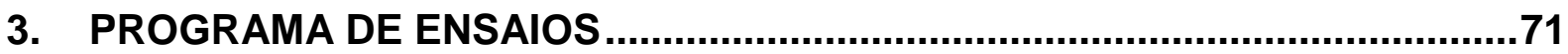




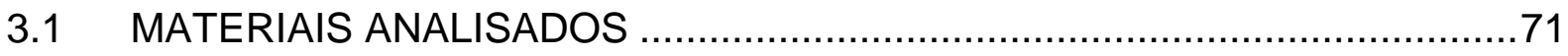

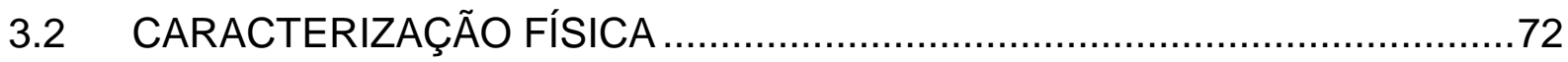

3.3 ANÁLISE DAS PROPRIEDADES MECÂNICAS …......................................72

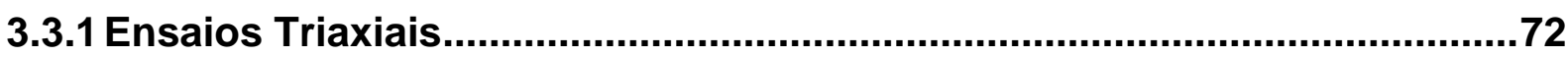

3.3.1.1 Triaxial de verdadeira grandeza - LTP .........................................

3.3.1.2 Triaxial em escala reduzida .......................................................

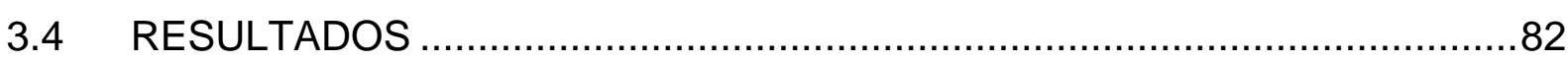

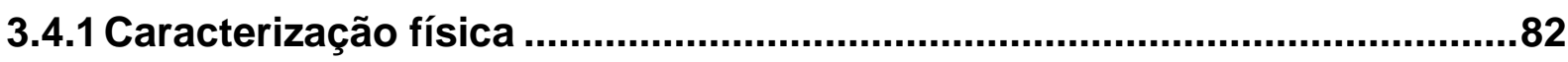

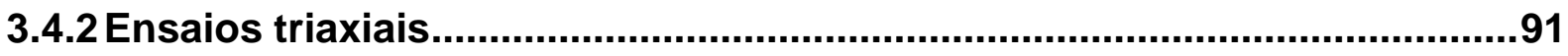

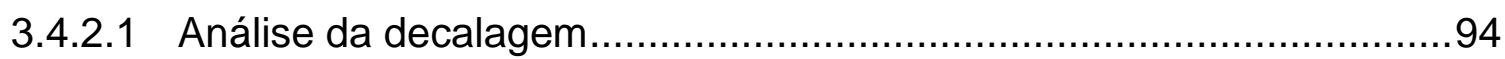

3.4.2.2 Efeito da contaminação ..........................................................103

3.4.2.3 Estudo da granulometria ........................................................110

3.4.2.4 Influência do carregamento ………………...............................122

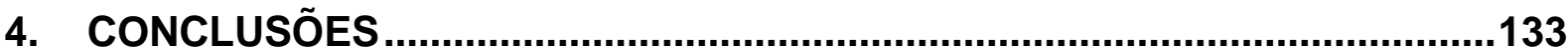

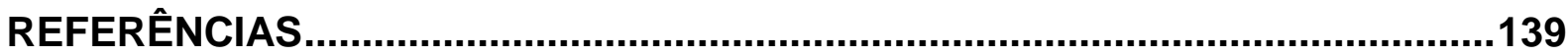




\section{INTRODUÇÃO}

A distribuição modal de transportes de carga no Brasil atual pode ser observada na Figura 1, sendo os percentuais de participação de cada modo estimados em função das quantidades de toneladas-quilômetro-úteis (TKUs), resultantes das simulações do Plano Nacional de Logística e Transporte (PNLT) para o ano de 2012. Evidentemente, os percentuais obtidos (especialmente no caso dos modais menos representativos) podem diferir de valores extraídos de outras fontes, considerando as premissas adotadas e os métodos utilizados.

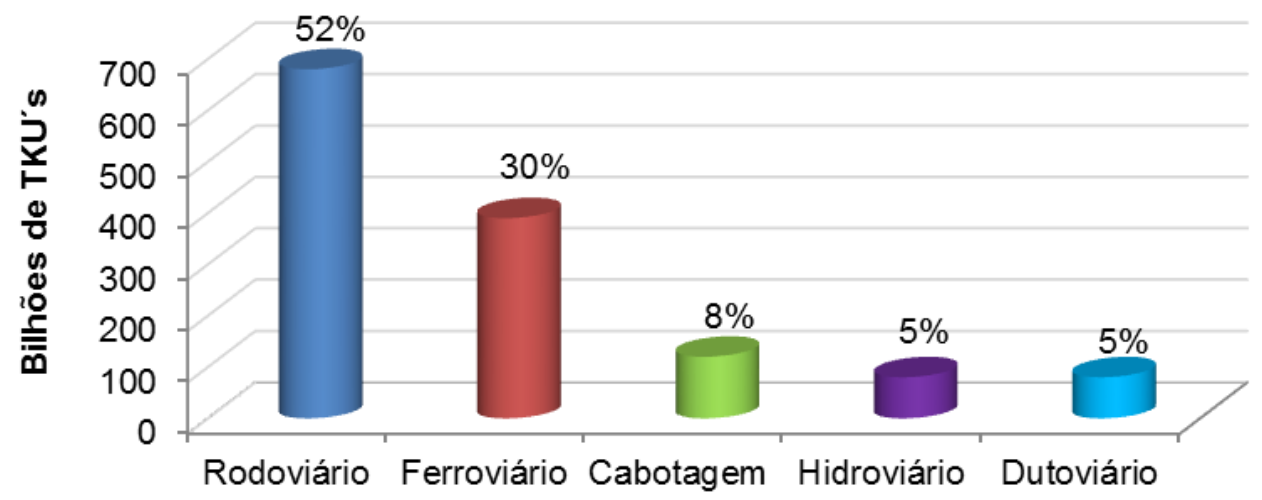

Figura 1 - Distribuição modal da matriz brasileira de transportes de cargas em 2011

(PNLT, 2012)

Durante décadas, o modo rodoviário recebeu ênfase e tornou-se fundamental na integração do país a partir de 1950, com a instalação da indústria automobilística e início das obras rodoviárias. A Figura 2 retrata a evolução da malha rodoviária em comparação às ferrovias nos últimos 15 anos. A diferença de investimentos entre os modais, dentre outros motivos, deu-se devido à possibilidade em realizar investimentos gradativos na malha rodoviária e ao mesmo tempo utilizá-la, ao contrário do modo ferroviário, que depende de uma grande soma de capital para realizar o início de suas operações. Tinha-se, assim, o modo rodoviário enquanto sistema de engenharia, ideal para realizar coesão espacial, pois além de possuir um traçado menos rígido, despendia menor volume inicial de investimento (SOUZA, 2009). Porém, nas décadas a partir dos anos 50, observou-se a falta de investimentos nos outros modais, principalmente no ferroviário, sobretudo devido ao aumento da produção nacional que, em geral, foi descentralizada, localizada em áreas de expansão de fronteira agrícola. Tais regiões apresentam uma baixa concentração de infraestrutura adequada para escoar a produção, tornando-se 
necessário perpassar do interior do país em direção ao litoral e integrar as diferentes tipologias de produção.

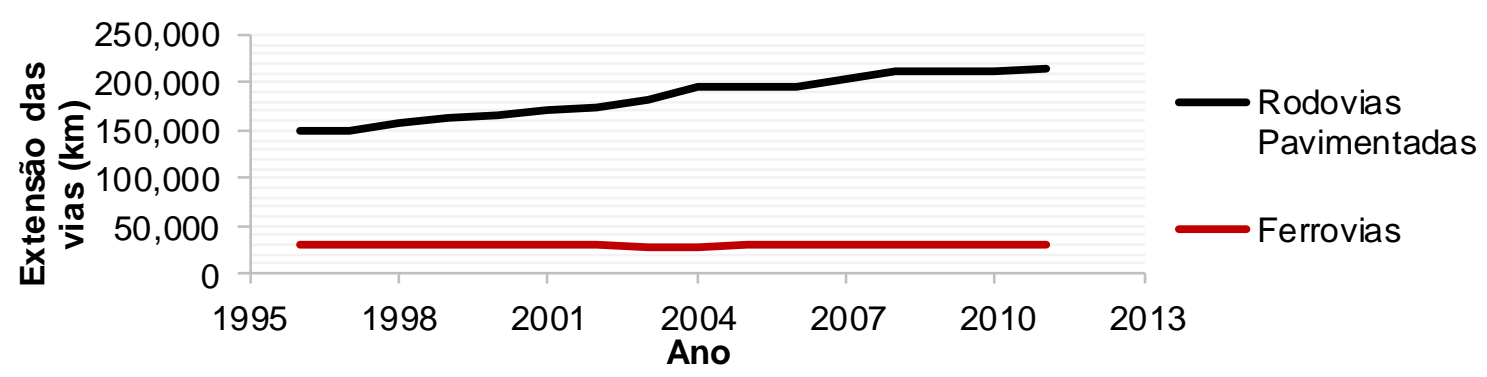

Figura 2 - Evolução da extensão $(\mathrm{km})$ das malhas rodoviária e ferroviária entre 1996 e 2011 (DNIT/ANTT/GEIPOT, 2011)

Segundo Araújo (2006), a solução então é proporcionar a melhoria na infraestrutura, o que garantirá aos nossos produtos maior competitividade no mercado externo, devido à redução dos custos logísticos. De acordo com estudos do Banco Mundial (Guasch, 2002), constata-se que, no Brasil, os custos logísticos representam, em média, $20 \%$ do valor do PIB - Produto Interno Bruto. A Figura 3 retrata, em termos percentuais, o quanto tal participação é elevada, ao se comparar as informações oriundas de outros países. Os custos logísticos demonstram o grau de importância exercido por sistemas de transporte eficientes, possuindo enorme influência na economia.

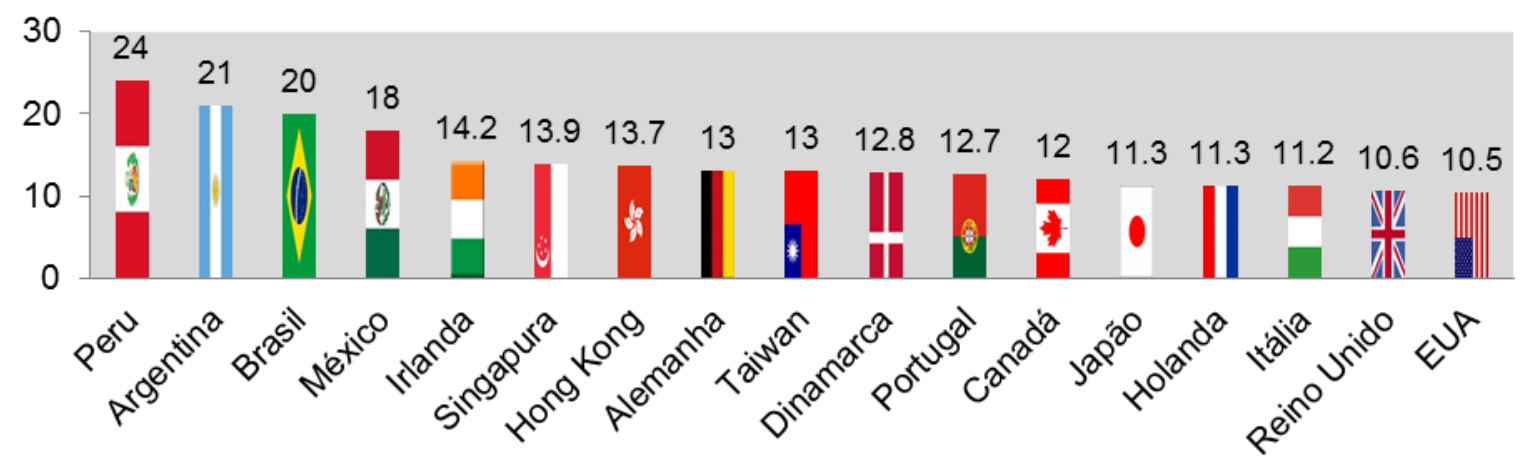

Figura 3 - Custos de Logística em \% do PIB (Guasch, 2002)

Fica, portanto, evidente que a racionalização dos custos de transportes poderá produzir efeitos significativamente benéficos sobre o componente mais expressivo dos custos logísticos. Junte-se a este raciocínio o fato de que, sob certas condições e para determinados fluxos de carga, os fretes hidroviários e ferroviários podem ser 
$62 \%$ e 37\%, respectivamente, mais baratos do que os fretes rodoviários (PNLT, 2012).

Diante disto, o Governo Federal tem concentrado esforços, através da Secretaria de Política Nacional de Transportes do Ministério dos Transportes (SPNT-MT), para dotar sua matriz de distribuição modal de uma situação equilibrada, a fim de maximizar as vantagens comparativas de cada modalidade de transporte e diminuir as disparidades entres os modais. Tais ações requerem a implantação de medidas institucionais e o aporte de significativos investimentos (PNLT, 2012).

A expansão do sistema ferroviário permitirá a racionalização do uso das rodovias e trará um melhor equilíbrio na matriz de transportes de cargas do País. A partir de então, foi consolidada a ampliação da malha ferroviária brasileira, com a sugestão de implantação de 11,8 mil km de novos trechos ferroviários, dos quais 10,7 mil km em bitola larga. As novas ferrovias vão atender às áreas de expansão da fronteira agrícola e de exploração mineral. Essa nova malha básica prepara o País para um novo ciclo de crescimento econômico, atendendo à expansão da demanda interna e à articulação com os portos exportadores (PNLT, 2012).

Até 2025, espera-se uma alteração na matriz de transporte brasileira, isto é, buscase a reversão da ênfase dada durante anos ao modo rodoviário. Para tanto, deve-se ampliar a participação do modo ferroviário de $25 \%$ para $32 \%$; do modo aquaviário de $13 \%$ para $29 \%$; do dutoviário de $3,6 \%$ para $5 \%$ e o aéreo de 0,4 para $1 \%$, reduzindo a participação do modo rodoviário de 58\% para 33\%. Entre 2005 e 2025, almeja-se ainda o aumento de $38 \%$ da eficiência energética, $41 \%$ na redução de combustível, $32 \%$ de redução de $\mathrm{CO}_{2}$ e $39 \%$ menor emissão de $\mathrm{NOx}$, tudo isso somente como benefícios resultantes da matriz de transporte, além de um aumento no volume de transportes de 851 para 1.510 Bi TKU (PNLT, 2012).

Como já visto, a rede ferroviária é parte essencial de um sistema de transporte eficaz e desempenha um papel vital na economia de um país. É o modo vocacionado para o transporte de massa, responsável pelo fluxo de cargas e mercadorias entre os importantes pólos econômicos, indústrias e terminais de carga, além de transporte de passageiros nos grandes centros urbanos. Nos últimos anos, a competição contínua com o transporte aéreo, rodoviário e hidroviário em termos de 
velocidade, capacidade de suporte e de custo aumentaram substancialmente a carga por eixo e frequência dos trens, exigindo maiores velocidades operacionais (ESVELD, 2001).

O aumento das cargas transportadas por eixo e da velocidade em que os trens trafegam acarretam em redução da vida útil da via, ocasionando uma degradação mais rápida das condições da ferrovia que estão relacionadas à geometria e um desgaste maior dos componentes. Como resultado, há necessidade de maior frequência de intervenções para manutenção (SELIG; WATERS, 1994). Segundo Indraratna et al. (2011), a Austrália, por exemplo, desempenha um papel importante no desenvolvimento e operações de vias férreas destinadas a trens superpesados. Inclui-se na política australiana de transporte de carga, a operação de trens com cerca de $3 \mathrm{~km}$ de extensão e vagões de 40 toneladas por eixo, em condições climáticas extremas.

A questão econômica para ferrovias de carga está intimamente ligada com a frequência de intervenções para a manutenção da via, daí a importância do conhecimento sobre as condições do sistema como elemento vital para encontrar a faixa ideal de manutenção. O desempenho de uma via férrea depende das características tecnológicas de todo o sistema, como interação veículo-via, interação entre a plataforma e a via permanente e condições ambientais (ESVELD, 2001; PROFILLIDIS, 2006).

Países como China, Austrália e EUA investem bilhões de dólares todos os anos no reparo e construção de vias férreas (INDRARATNA et al., 2011). Segundo dados do Ministério de Ferrovias do Governo chinês, em 2012 foram investidos 507 bilhões de yuans (US\$ 103 bilhões) e, em 2013, estima-se um crescimento de 30\% em relação ao ano anterior, totalizando 650 bilhões de yuans (US\$ 134 bilhões) que serão aplicados em infraestrutura, principalmente nas redes ferroviárias e metroviárias para estimular a economia (IRJ, 2011). Segundo Baumgartner (2001), o valor investido apenas com a infraestrutura ferroviária na Europa está na casa de $€ 7.000 .000,00 / \mathrm{km}$. A partir destes dados, é possível perceber que o uso eficiente destes recursos é uma tarefa desafiadora, que exige tecnologias avançadas e inovadoras em engenharia ferroviária. 
A manutenção da via é uma rotina de atividade cara, com maior proporção gasta devido aos problemas geotécnicos da subestrutura ${ }^{1}$ (SELIG; WATERS 1994, IONESCU et al., 1998, WHEAT; SMITH, 2008). Segundo Selig e Waters (1994), Esveld (2001), Indraratna e Salim (2005), a superestrutura ${ }^{2}$ foi a região da via permanente que recebeu maior atenção no passado, enquanto que a subestrutura, que é composta de materiais naturais e possuem propriedades muito variáveis e de difícil definição, recebeu menos importância. O enorme custo envolvido na manutenção da subestrutura pode ser significativamente reduzido se o melhor entendimento das características físicas e mecânicas desta região for obtido.

A seleção de técnicas convenientes para aumentar a estabilidade e a segurança da via permanente é essencial para assegurar a confiabilidade da indústria ferroviária e garantir capacidade suficiente para suportar novos aumentos da carga, sem a ocorrência de acidentes. Segundo Raymond (1985), o custo de um descarrilamento é da ordem de vários milhões de dólares, podendo ser agravado quando envolve o transporte de produtos perigosos em áreas urbanas, ocasionando até perda de vidas. Estes eventos trágicos são frequentemente relacionados com a perda de nível e a instabilidade geométrica da via. Controlar o perfil de pista e alinhamento, perante aos efeitos de vibrações aplicadas aos elementos por cargas dinâmicas é essencial. Segundo Shenton (1975), o lastro é o único componente externo que possibilita a regularização e nivelamento da superfície da via.

A grande parcela da rede ferroviária no Brasil está a cargo das empresas privadas, pois foi a política encontrada para resolver, em curto e médio prazos, a modernização da malha e propiciar uma operação mais eficiente. A engenharia ferroviária precisa determinar as formas e meios de reduzir os custos de manutenção no sistema e buscar melhorias (e mesmo inovações) para suas novas obras. A fim de reduzir estes custos e otimizar a rede, uma compreensão completa do comportamento dos materiais da subestrutura, como por exemplo do lastro, é indispensável.

\footnotetext{
${ }^{1}$ Faixa constituída por materiais geotécnicos com uma ou duas camadas granulares sobrejacentes ao subleito

${ }^{2}$ Parte superior da estrutura ferroviária composta pelos trilhos, fixações e dormentes.
} 


\subsection{IMPORTÂNCIA DO TEMA}

Ultimamente, extensos investimentos vêm sendo feitos na matriz ferroviária em vários países pelo mundo, como alternativa para o transporte de cargas e passageiros. No Brasil, o Programa de Investimento em Logística (PIL) lançado pelo governo prevê aplicação de $\mathrm{R} \$ 91$ bilhões, tanto na manutenção de vias já existentes, quanto na construção de $11.000 \mathrm{~km}$ de novas vias, com o objetivo de dirimir o déficit de infraestrutura de transportes, reduzir o custo Brasil e tornar o país mais competitivo no mercado internacional. Por consequência, a evolução deste modo passa por extensa pesquisa e desenvolvimento tecnológico, haja vista que as mudanças nas características de tráfego e volume de transporte necessitarão de um sistema ferroviário confiável, com diminuição nos custos de manutenção e níveis aceitáveis de segurança.

A necessidade de extensa pesquisa voltada aos componentes do sistema ferroviário, dentre eles o lastro, se faz necessária devido a três fatores: (i) carência de pesquisas nesta área; (ii) necessidade de expansão da rede e (iii) o surgimento de uma ampla oportunidade de desenvolvimento de uma base de conhecimento científico nacional, que estará fundamentada na evolução da matriz ferroviária.

Uma melhor compreensão do sistema ferroviário permite localizar e corrigir problemas, evitando desgastes acelerados e falhas prematuras em componentes da via. O estudo dinâmico da via propiciará planos de manutenção mais precisos e uma redução na necessidade de intervenções rotineiras que são, por vezes, pouco planejadas. A relevância de uma melhor compreensão do comportamento mecânico das vias permanentes está diretamente relacionada ao forte papel logístico do modo. 


\subsection{OBJETIVOS E METAS}

O principal objetivo deste estudo é propiciar um melhor entendimento do comportamento mecânico da camada de lastro ferroviário, por meio de ensaios laboratoriais triaxiais cíclicos de grande e pequena escala.

Para atingir este objetivo, algumas etapas de pesquisa serão realizadas:

- Desenvolvimento de um aparato triaxial em verdadeira grandeza $(400 \times 800$ $\mathrm{mm}$ ), cujo equipamento permite ensaios que simulam as tensões na camada de lastro de vias de maneira mais realista, em agregados de grandes dimensões, sem a perda de representatividade da amostra. Testes em câmara cilíndrica de larga escala permitirão ensaios adequados, a fim de se chegar a uma melhor compreensão do complexo fenômeno da deformação e degradação do lastro que é submetido à carga dinâmica. Desta forma, o efeito dos parâmetros que afetam o comportamento do lastro poderá ser quantificado.

- Análise experimental para investigar o comportamento tensão-deformação do lastro com duas diferentes e usuais graduações, sob diferentes condições de ciclos de carregamento e níveis de tensão. Serão realizadas ainda análises de degradação e respostas por contaminação do material, perante o tráfego e ciclos de manutenção, visando obter uma melhor previsão da vida útil do lastro.

- A influência das condições de teste, tensão e o efeito da distribuição do tamanho de agregado sobre o comportamento tensão-deformação e degradação de material de lastro também serão estudadas usando ensaios triaxiais convencionais $(150 \mathrm{~mm} \times 300 \mathrm{~mm})$, a fim de analisar a decalagem por graduação paralela. 


\subsection{ESCOPO DA PESQUISA}

Este trabalho é resultado de uma extensa pesquisa voltada ao estudo do comportamento do lastro ferroviário conduzido pelo Laboratório de Tecnologia de Pavimentação da Escola Politécnica da Universidade de São Paulo, em parceria com a empresa Vale S.A.O foco principal deste projeto é o trabalho experimental que visa avaliar cuidadosamente as características do lastro ferroviário em condições de carga variadas e complexas, e determinar a influência dos principais parâmetros que afetam o comportamento da estrutura.

As conclusões retiradas a partir do estudo têm a função de contribuir para um projeto de vias férreas mais eficientes e, desta forma, minimizar a deformação e a degradação da camada de lastro, que permitirá o nivelamento adequado da via por mais tempo e, consequentemente, reduzir os custos de manutenção. Espera-se que esta pesquisa gere mais interesse entre os pesquisadores e engenheiros no campo da geotecnia voltada às linhas férreas e auxilie no desenvolvimento ferroviário nacional.

O objetivo final é proporcionar uma melhor compreensão deste tema complexo, trazer uma melhoria no projeto e manutenção da infraestrutura da via, e auxiliar na rápida adoção de tecnologias de ponta para minimizar os custos, promovendo vias de alta confiabilidade. 


\subsection{ORGANIZAÇÃO DO TRABALHO}

Esta pesquisa está organizada em quatro capítulos. O primeiro é a INTRODUÇÃO do trabalho, onde são estabelecidos os objetivos, o escopo e a organização da pesquisa. O segundo capítulo aborda o tema SISTEMA FERROVIÁRIO e trata dos componentes da estrutura ferroviária e mecanismo transferência de esforços, além de abordar detalhes específicos do comportamento mecânico do lastro ferroviário e métodos de avaliação deste comportamento por meio de ensaios de campo e laboratório. O capítulo três, intitulado PROGRAMA DE ENSAIOS, relata detalhadamente a sequência de procedimentos adotados para a realização dos ensaios, desde a coleta do material até a sua caracterização física e mecânica (incluindo neste caso, a avaliação do comportamento do material por meio de ensaios triaxiais cíclicos), sendo os resultados agrupados de acordo com as diferentes análises propostas. Por fim, o quarto capítulo traz as CONCLUSÕES de todo o estudo. 


\section{SISTEMA FERROVIÁRIO}

O desempenho das vias férreas resulta de uma complexa interação dos diversos elementos e camadas do sistema, em resposta às solicitações impostas pelo trem. $O$ objetivo da estrutura ferroviária é fornecer estabilidade, segurança e uma base eficiente para que os trens funcionem em velocidades e cargas por eixo diferentes, proporcionando um transporte econômico, confiável e confortável. Para atingir estes objetivos, a geometria da via deve ser mantida e cada componente da estrutura deve desempenhar suas funções de forma satisfatória, sob diferentes condições ambientais e operacionais (INDRARATNA et al., 2011).

Segundo Esveld (2001), são dois os tipos de estruturas ferroviárias comumente utilizadas: as vias convencionais que se utilizam do lastro como suporte flexível e as vias apoiadas sobre placas de concreto (Figura 4). O modelo ferroviário convencional é amplamente adotado, embora ultimamente vias não apoiadas sobre lastro têm sido utilizadas no Japão e em alguns países da Europa, dependendo das características de carga de deformação do subleito.

Estudos recentes indicam que as vias de laje podem ser mais rentáveis do que as convencionais quando se considera seus ciclos de vida, custo de manutenção e o período de interrupção do tráfego durante a manutenção (ESVELD, 2001; PROFILLIDIS, 2006). No entanto, detalhes construtivos complexos e custo de construção inicial elevado limitam de alguma forma o uso generalizado de vias de laje, razão pela qual o modelo tradicional ainda é amplamente adotado (INDRARATNA et al., 2011). 
(a)
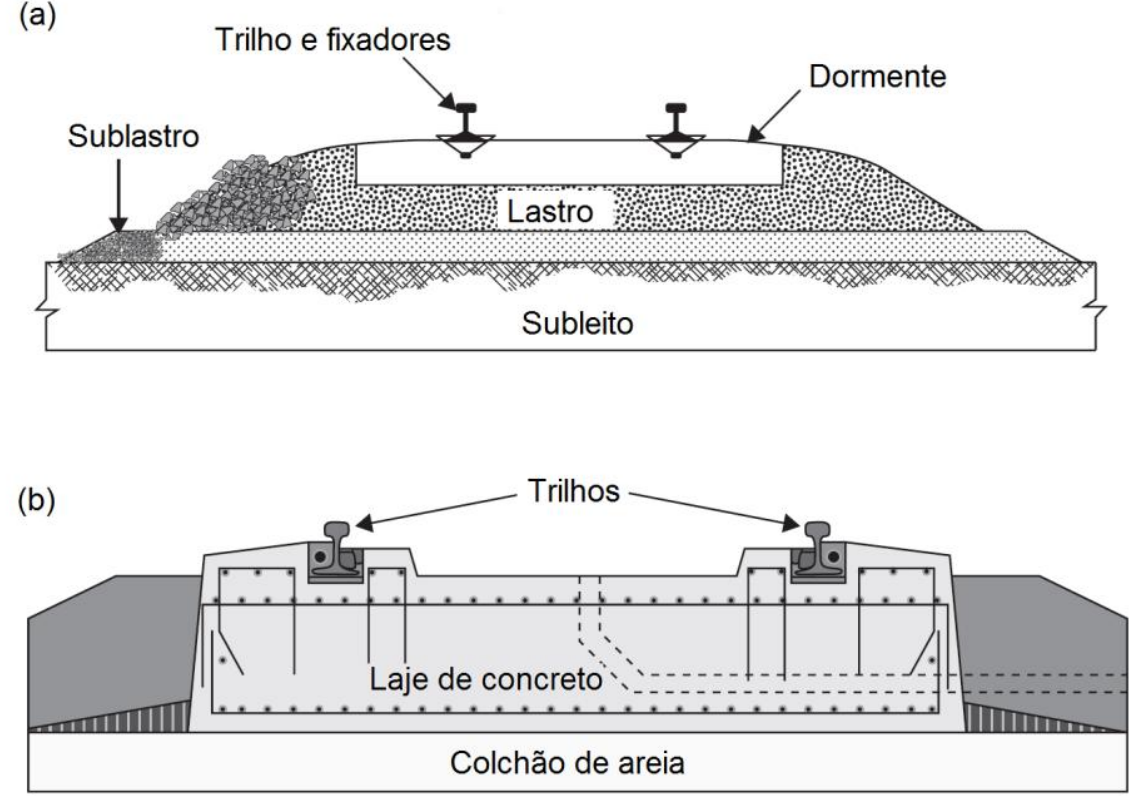

Figura 4 - (a) Seção típica de via ferroviária convencional e (b) seção de via sobre laje de concreto (Indraratna et al., 2011)

\subsection{VIA CONVENCIONAL E MECANISMO DE TRANSFERÊNCIA DE ESFORÇOS}

A estrutura ferroviária clássica basicamente consiste de uma estrutura plana constituída por trilhos, dormentes e fixações que são apoiados pelo lastro. O lastro então é assentado acima do sublastro que, em conjunto, formam a camada de transição para a plataforma (ESVELD, 2001).

O modelo clássico é, aparentemente, uma estrutura simples e a sua composição parece ter evoluído pouco desde o início das primeiras ferrovias. Contudo, importantes desenvolvimentos ocorreram após a Segunda Guerra Mundial, incluindo introdução de trilhos contínuos soldados, uso de dormentes de concreto, adoção de perfis de trilhos mais pesados, inovações nas fixações, introdução de equipamentos modernos de medição e mecanização da manutenção, juntamente com a adoção de sistemas de controle (ESVELD, 2001; FORTUNATO, 2005; PROFILLIDIS, 2006).

Um problema comum neste tipo de via é a progressiva deterioração do lastro causada pela passagem do tráfego. A quebra das arestas e a fratura de agregados 
sob carga cíclica elevada causam assentamentos na via e irregularidades geométricas (SELIG; WATERS, 1994). Para manter o desejado nível de segurança, velocidade, geometria e conforto dos passageiros, a manutenção de rotina é fundamental em uma via de lastro (INDRARATNA et al., 2011).

\subsubsection{Estrutura}

Segundo Selig e Waters (1994), a estrutura da via convencional é dividida em duas partes, a saber, a superestrutura e a subestrutura, que são as partes superior e inferior, respectivamente, conforme mostrado na Figura 5. A superestrutura inclui os trilhos, o sistema de fixação e dormentes, sendo separada da subestrutura pela interface dormente-lastro, que é a região mais importante na distribuição de esforços às camadas mais profundas. A subestrutura inclui lastro, sublastro e subleito, que são os materiais geotécnicos dentro do sistema ferroviário.

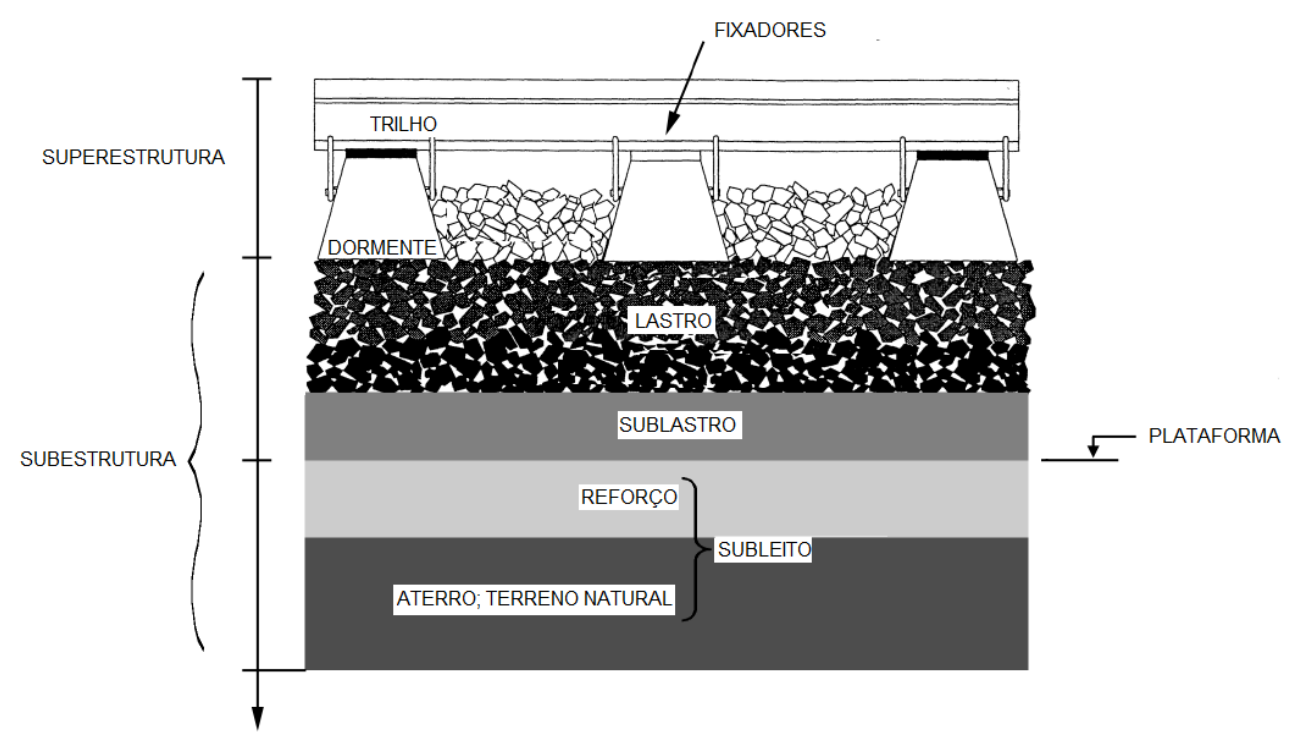

Figura 5 - Estrutura ferroviária convencional e seus componentes (Selig e Waters, 1994)

Segundo Selig e Waters (1994) e Indraratna e Salim (2005), a superestrutura foi a região que recebeu maior atenção no passado sendo exaustivamente analisada e estudada. Diversas pesquisas foram fomentadas na Europa e Estados Unidos para o desenvolvimento de trilhos, dormentes e fixações (ESVELD, 2001).

Por outro lado, a subestrutura, que é composta de materiais naturais que possuem propriedades muito variáveis e de difícil definição, recebeu menor importância. Os 
elevados custos envolvidos na manutenção da subestrutura podem ser significativamente reduzidos se o melhor entendimento das características físicas e mecânicas dos componentes geotécnicos for obtido.

Trilhos são elementos de aço longitudinais que estão em contato com as rodas do trem. A função dos trilhos é guiar o trem e transferir as cargas concentradas para os dormentes. Assim, os trilhos devem ter rigidez suficiente para distribuir as cargas de rodas sobre os dormentes e limitar a deflexão entre os mesmos. Defeitos e descontinuidades, ocorridos nas soldas, podem causar grandes cargas de impacto, que têm efeitos prejudiciais sobre todos os componentes da via, inclusive no veículo.

O sistema de fixação mantém os trilhos atrelados aos dormentes e resiste movimentos verticais, longitudinais e transversais. Dormentes de madeira requerem placas de aço no seu sistema de fixação para distribuir a força de trilho sobre a superfície da madeira. Dormentes de concreto requerem apoios resilientes do sistema de fixação para fornecer resiliência e amortecimento para a superestrutura. As principais funções dos dormentes são a distribuição das cargas de roda transferidas pelos trilhos e sistema de fixação para a camada de lastro, e a restrição do movimento do trilho pela ancoragem da superestrutura no lastro (ESVELD, 2001).

O lastro é um material granular densificado e colocado no topo da subestrutura, que envolve, até certa parte, os dormentes. Dentre suas funções mais importantes destacam-se: resistir aos esforços verticais, laterais e longitudinais aplicados pelo trem aos trilhos, fixações e dormentes, e ainda possuir resiliência adequada, que permita a absorção da energia oriunda do contato roda-trilho. Além disso, os vazios fornecem a drenagem necessária da água na via. Entretanto, os espaços vazios no lastro, eventualmente, podem ser preenchidos com material de fino e, assim, o lastro terá de ser limpo ou substituído (SELIG; WATERS, 1994).

O sublastro é a camada de separação entre lastro e subleito. Esveld (2001) destaca que esta camada reduz os níveis de tensão adicional para o subleito, tornando-se uma opção mais barata do que utilização de uma camada de lastro mais espessa. No entanto, a função mais importante desta camada é impedir a interpenetração entre o subleito e o lastro, servindo como um filtro. Sua composição é realizada 
basicamente por materiais bem graduados como misturas de areia e cascalho (SELIG; WATERS, 1994).

Subleito é a base para a estrutura da via. Ele pode ser formado apenas por solo natural compactado, quando de boa qualidade, caso contrário é aconselhável seu tratamento ou adoção de camada tratada com material de melhor qualidade (PROFILLIDIS, 2006). A função principal do subleito é proporcionar uma fundação estável para a estrutura da via. Segundo pesquisas de Selig e Waters (1994), o tráfego de trens de carga induzem tensões que se estendem a mais de cinco metros de profundidade da base do dormente, ou seja, extrapolando-se as extensões das camadas de lastro e sublastro. Por isso, o subleito possui uma grande importância e influência no desempenho e manutenção da via.

Selig e Waters (1994) destacam ainda que o subleito é o componente que possui a maior influência no que diz respeito à resiliência da estrutura ferroviária, pois contribui substancialmente para as deflexões e propicia o confinamento do lastro. Desta forma, deformações excessivas no subleito devem ser evitadas.

\subsubsection{Forças atuantes}

Com o objetivo de analisar e projetar uma via férrea tradicional com subestrutura resiliente, o tipo e magnitude das cargas que serão impostas sobre a estrutura, durante a vida útil, devem ser quantificados. As cargas impostas pela passagem dos trens aos trilhos geram uma complexa reação de cargas estáticas e dinâmicas.

O conjunto de elementos que constituem a via permanente possibilita a transferência das cargas provenientes da passagem dos veículos para a fundação (Figura 6). Cada um dos elementos absorve parte das tensões que nele chegam, transmitindo tensões menores para a camada seguinte (ESVELD, 2001). 


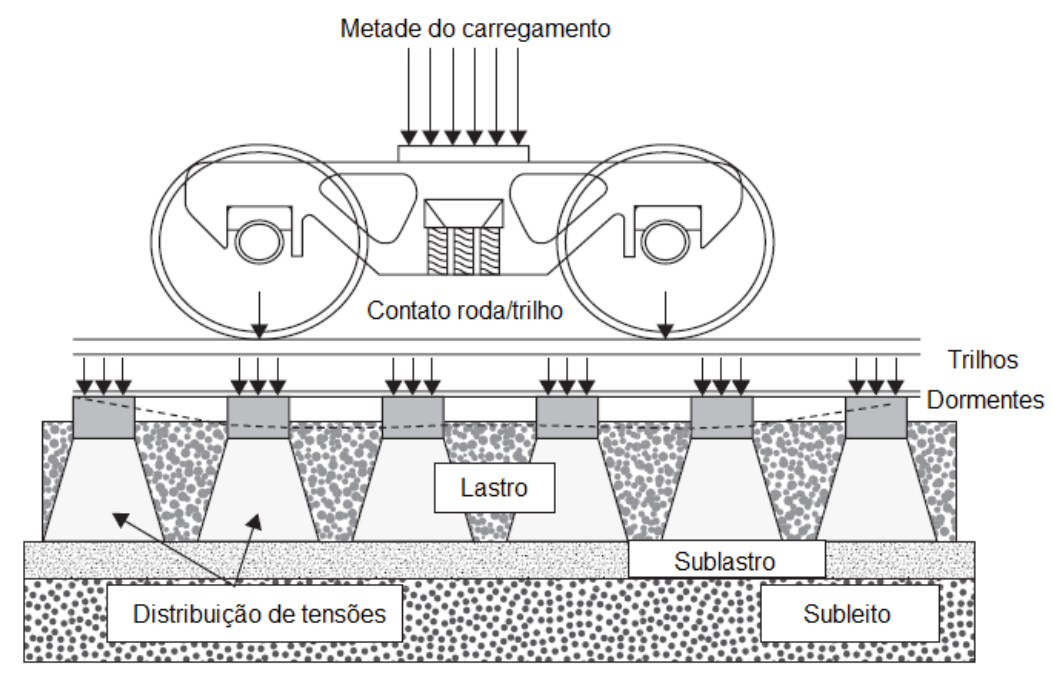

Figura 6 - Representação da distribuição de tensões verticais entre os componentes (RailCorp, 2010)

Os requisitos para a capacidade de carga da estrutura e a qualidade da via permanente dependem, em grande parte, da carga vertical por eixo, quantidade de passagens de cargas por eixo e velocidade de circulação. A tonelagem acumulada determina a deterioração do sistema e indica quando os ciclos de manutenção e renovação são necessários (INDRARATNA et al., 2011).

Forças nas direções vertical, lateral e longitudinal agem sobre a estrutura da via. Estas forças podem ser devido ao movimento do tráfego e às mudanças de temperatura. Segundo Esveld (2001), esforços laterais e longitudinais são muito complexos e mais difíceis de serem previstos que componentes verticais.

A força longitudinal é geralmente devida à aceleração ou frenagem dos trens e a expansão ou contração térmica dos trilhos. A força lateral geralmente resulta do esforço lateral da roda, devido ao atrito entre a roda e trilho (contato roda-trilho), especialmente em curvas. Tal força origina-se também da força de reação à flambagem do trilho, que geralmente é causada por um elevado esforço longitudinal na peça (ESVELD, 2001).

Segundo Esveld (2001) e Profillidis (2006), a força vertical pode ser subdividida em dois sentidos, ascendente ou descendente. Em reação à força descendente, a força ascendente é induzida pelo trilho. A força descendente é uma combinação de uma carga estática e um componente dinâmico. A carga estática é composta pelo peso do trem e da superestrutura, enquanto que o componente dinâmico, conhecido como 
incremento dinâmico, é função das condições de via, características do trem, condições de operação, velocidade, e das condições ambientais. É o componente dinâmico que normalmente provoca um efeito adverso para a via, uma vez que pode ser muito maior do que a carga estática. De acordo com Selig e Waters (1994), a magnitude da componente dinâmica pode ser de até 2,4 vezes a carga estática.

Selig e Waters (1994) destacam outro esforço que pouco é considerado, e está relacionado às operações de manutenções por socaria. Estas operações causam esforços que degradam o lastro, pois os agregados são vibrados e atenuados por frequências elevadas devido à inserção das garras compactadoras (WRIGHT, 1983).

\subsubsection{Transmissão de tensões}

Segundo Profillidis (2006), existe uma variedade de métodos que caracterizam a transmissão dos esforços ao longo da estrutura ferroviária. Desde métodos antigos, baseados na análise de um sistema de multicamadas com comportamento elástico, até métodos mais modernos que adotam análise por elementos finitos, os quais permitem considerar no cálculo a geometria da estrutura e a relação tensãodeformação dos materiais. Porém, problemas relativos às condições de contorno, principalmente na interface entre materiais diferentes (trilho-dormente e dormentelastro) são encontrados.

Tradicionalmente, na análise de tensões na via permanente é utilizado o modelo clássico de Winkler ${ }^{3}$ (1867 apud KERR, 1977) que consiste de um sistema estrutural composto de duas vigas contínuas paralelas, os trilhos, apoiadas em dormentes longitudinais sobre uma fundação contínua, elástica e uniforme. Nesta hipótese, em cada ponto de suporte, as tensões são proporcionais aos deslocamentos (ESVELD, 2001). Esta abordagem é atualmente o método dominante na engenharia ferroviária. A Figura 7 representa o problema físico (a) e o modelo analítico correspondente (b), desenvolvido por Winkler.

\footnotetext{
${ }^{3}$ WINKLER, E. Vortrage uber Eisenbahnbau. Verlag H. Dominicus. Praga, República Tcheca, 1867.
} 


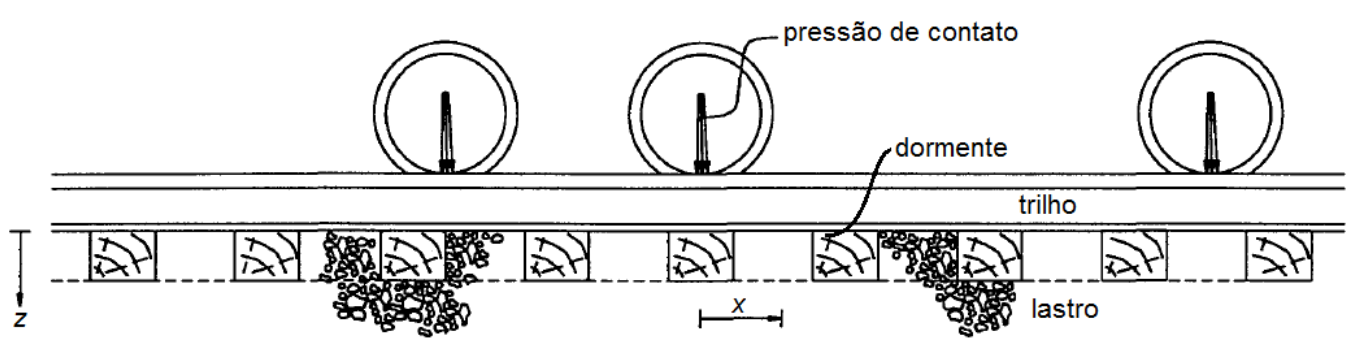

(a) Problema Físico

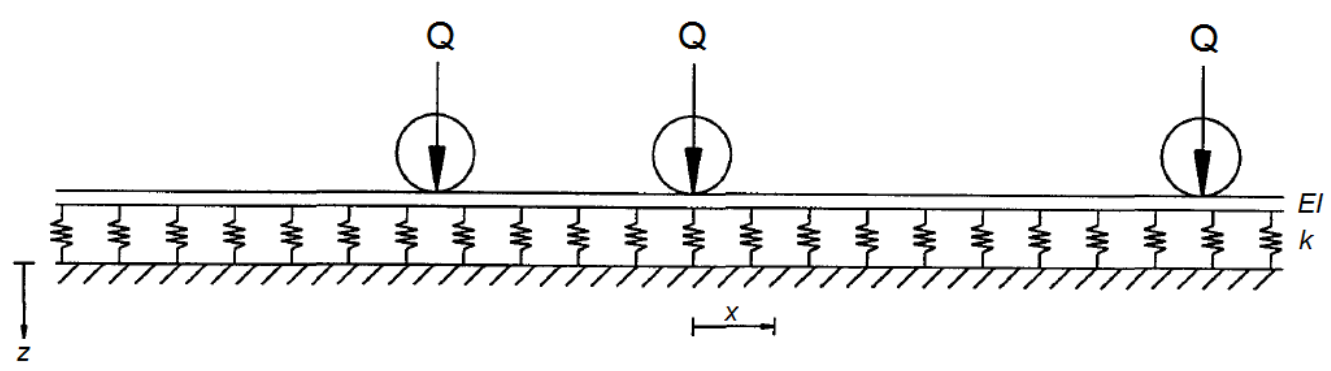

(b) Modelo Analítico

Figura 7 - Representação esquemática da via e seu modelo analítico (Bathrust e Kerr, 1995)

O modelo de Winkler, apresentado em 1867, foi a primeira tentativa bem sucedida. A resultante das forças que atuam nos dormentes é dada pela Equação 1, considerando que a área de influência de cada dormente é dada pelo seu espaçamento em relação aos outros. Além da hipótese de apoio, a teoria utilizada também supõe que as forças longitudinais, decorrentes da variação de temperatura e das forças de aceleração e frenagem dos veículos, que atuam no eixo do trilho são desprezíveis e não existem momentos fletores distribuídos ao longo do eixo do trilho. 


$$
F=u \cdot y(x) \cdot a=\frac{\beta \cdot F I D \cdot Q_{0} \cdot a}{2} e^{-\beta|x|}(\operatorname{sen} \beta|x|+\cos \beta|x|)
$$

Onde:

$F$ : Força resultante atuante em determinado dormente, distanciado a " $x$ " metros do ponto de aplicação de carga (kN);

u: Módulo de via $(\mathrm{kPa})$;

$y(x)$ : Deflexão no eixo do trilho distanciado a " $x$ " metros do ponto de aplicação de carga $(m)$;

a: Espaçamento entre dormentes $(\mathrm{m})$;

$\beta=\left(\frac{u}{4 E \cdot I}\right)^{0,25}\left(\mathrm{~m}^{-1}\right)$;

FID: Fator de incremento dinâmico;

$\mathrm{Q}_{0}$ : Carga vertical $(\mathrm{kN})$;

$\mathrm{x}$ : Eixo de referência do trilho ao ponto de aplicação de carga (m).

Em 1918, um comitê especial, organizado conjuntamente pela American Society of Civil Engineers (ASCE) e American Railway Engineering Association (AREA) coordenado por Talbot, então professor da Universidade de Illinois, realizou vários ensaios que evidenciaram uma boa correlação entre os resultados analíticos obtidos com a formulação de Winkler e a resposta obtida em campo. A partir daí, então, a hipótese de apoio contínuo parecia justificável já que, com o aumento da carga por eixo, os dormentes passaram a serem colocados uns mais próximos aos outros. Desde a Segunda Guerra Mundial, este tipo de análise de tensões é aceita de um modo geral, como pode ser evidenciado por sua inclusão nos livros de Hay (1982), Esveld (2001) e no manual da American Railway Engineering and Maintenance-ofWay Association - AREMA (2009).

Vale destacar que, no desenvolvimento deste tipo de análise, a carga considerada é sempre a carga por eixo estática, majorada por coeficientes que levam em consideração o efeito de cargas dinâmicas acidentais ou o tráfego de veículos em trechos curvos da via. 


\section{Esforços na camada de lastro}

A dificuldade para determinar as tensões que atuam nas camadas granulares pôde ser observada pela complexidade analítica, já destacada anteriormente. Além do contato entre dormente e lastro se alterar com o tempo, a maneira como ocorre a transmissão de tensões entre estes elementos não é completamente compreendida.

Shenton (1975) analisou em campo a distribuição da pressão de contato entre o dormente e o lastro. Este estudo foi realizado em camadas de lastro com agregados entre 25 e $50 \mathrm{~mm}$ e dormentes com largura de $250 \mathrm{~mm}$. A pesquisa mostrou que o número de agregados envolvidos diretamente no suporte do dormente era relativamente reduzido. Ele estimou a existência de 100 e 200 pontos de contato entre a interface dormente-lastro, evidenciando assim a dificuldade para a correta estimativa de tensão entre estes materiais.

A Figura 8 exemplifica medições realizadas por Shenton nas ferrovias inglesas. A distribuição da pressão de contato entre o dormente e o lastro é muito instável e varia de teste para teste (SHENTON, 1975). No entanto, estas medidas de campo fornecem uma indicação da pressão máxima exercida pelo dormente no lastro, sob uma carga por eixo de $200 \mathrm{kN}$.

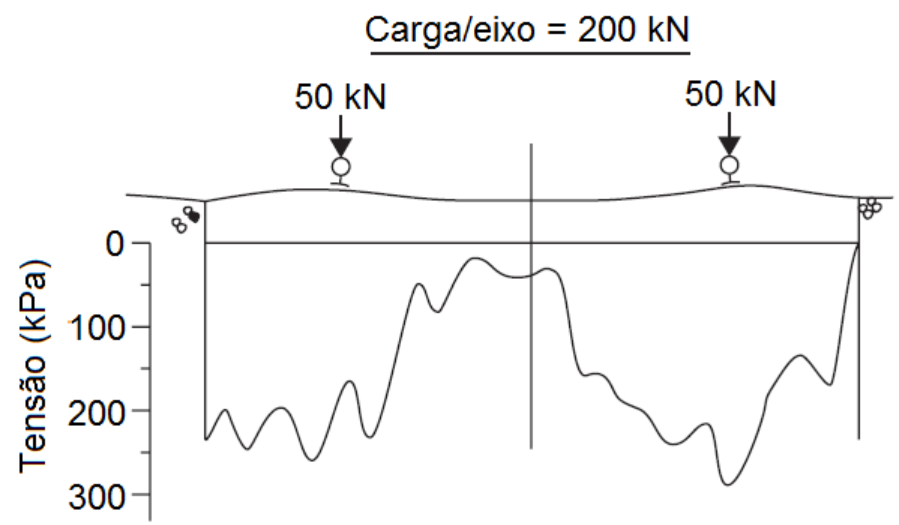

Figura 8 - Medições das tensões de contato entre dormente e o lastro (Shenton, 1975)

Jeffs e Tew (1991) exemplificam um modelo da distribuição de tensões do dormente ao lastro. Segundo estes autores, as tensões se concentram em 2/3 do dormente, 0 que se aproxima muito das medidas realizadas por Shenton (1975), conforme representado na Figura 9. 


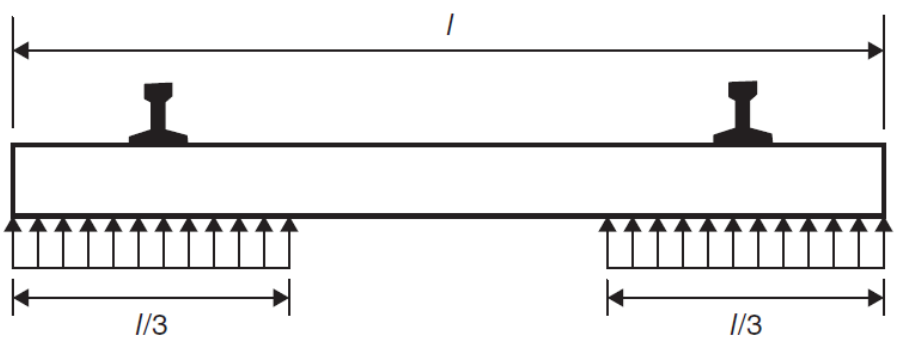

Figura 9 - Simplificação da distribuição de tensões entre o dormente e o lastro (Jeffs e Tew, 1991).

Indraratna et al. (2010a) monitoraram um trecho de $60 \mathrm{~m}$ de uma ferrovia em Bulli, na Austrália, com o objetivo de entender a dissipação de tensões ao longo das camadas da subestrutura, na qual o material de lastro era composto por agregados britados de basalto e lastro reciclado. A espessura média de lastro era de $300 \mathrm{~mm}$ e a do reforço de subleito era de $150 \mathrm{~mm}$. Detalhes da instrumentação utilizada e estrutura da via estão exemplificados na Figura 10.

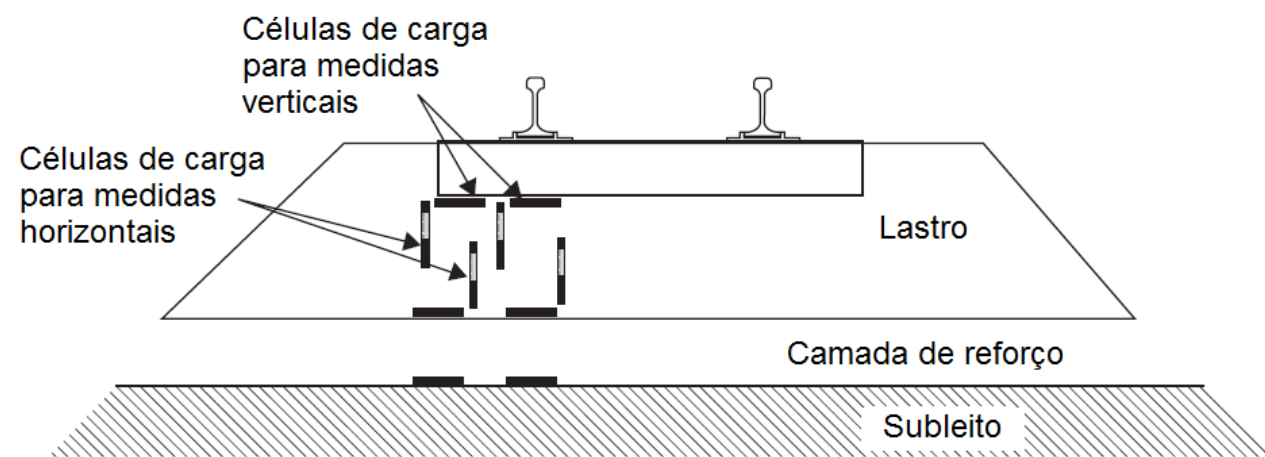

Figura 10 - Representação esquemática da distribuição das células de carga na via (Indraratna et al., 2010)

As leituras foram realizadas em intervalos programados que totalizaram um período de 17 meses, perfazendo um total de 90 milhões de toneladas brutas transportadas. A Figura 11 mostra as máximas tensões horizontais e verticais medidas, tanto na interface dormente-lastro quanto na interface lastro-sublastro, para a passagem de trem de passageiro de $82 \mathrm{t}$ e trem de carga com 100 t (25 t/eixo), ambos com velocidades de $60 \mathrm{~km} / \mathrm{h}$. As medidas foram realizadas na direção dos eixos dos trilhos e na borda de dormentes, para diferentes períodos. 


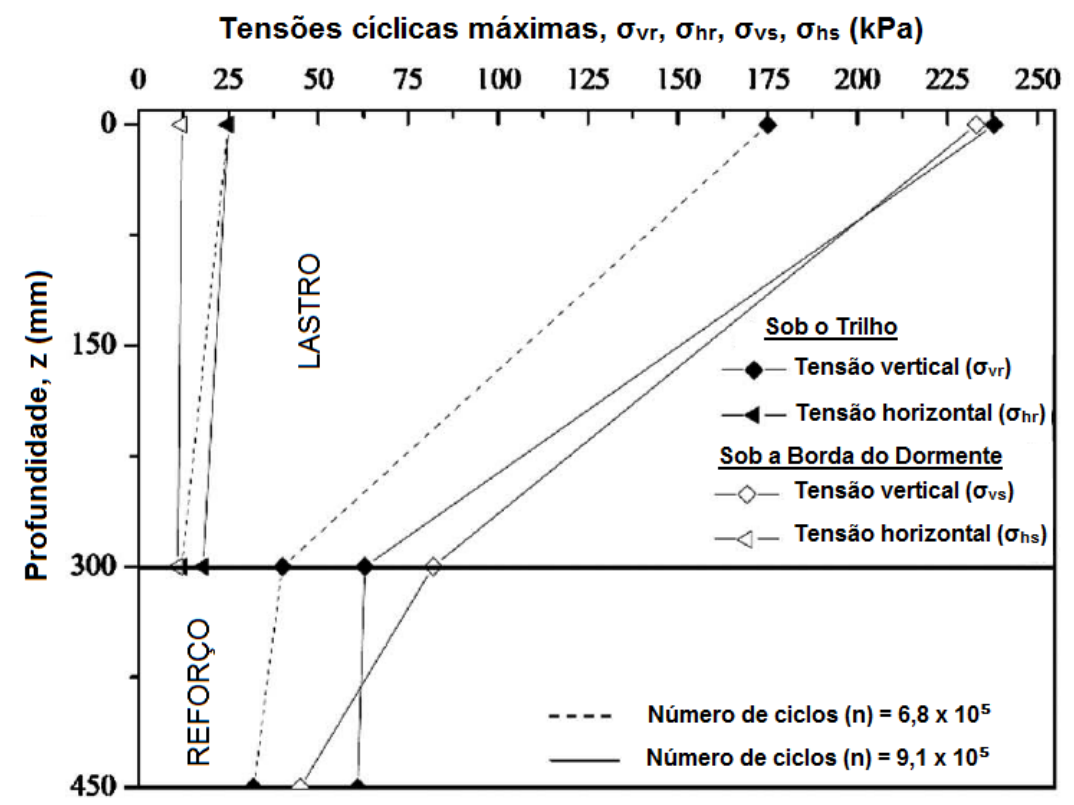

(a)

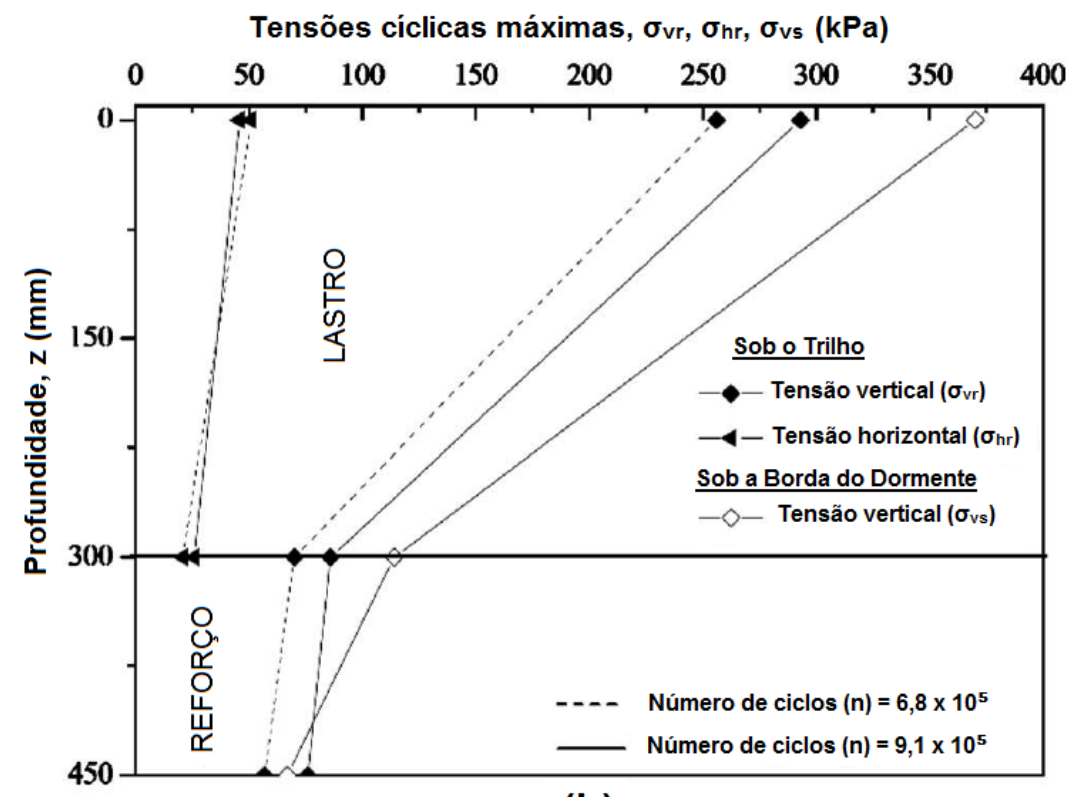

(b)

Figura 11 - Tensões verticais e horizontais máximas medidas para: (a) trem de passageiros com 82 t; (b) trem de carga com vagões de 100 t (Indraratna et al., 2010a)

Para o mesmo estudo, medições das tensões verticais, sob eixo do trilho, ao longo do tempo, para um trem de carga de 100 t estão plotados na Figura 12. As tensões cíclicas possuem valores em torno de $230 \mathrm{kPa}$, porém um pico de $415 \mathrm{kPa}$ é medido. Tal diferença foi descoberta posteriormente como um problema em uma das rodas do trem, exemplificando, desta forma, grandes impactos gerados por imperfeições no contato roda-trilho. 


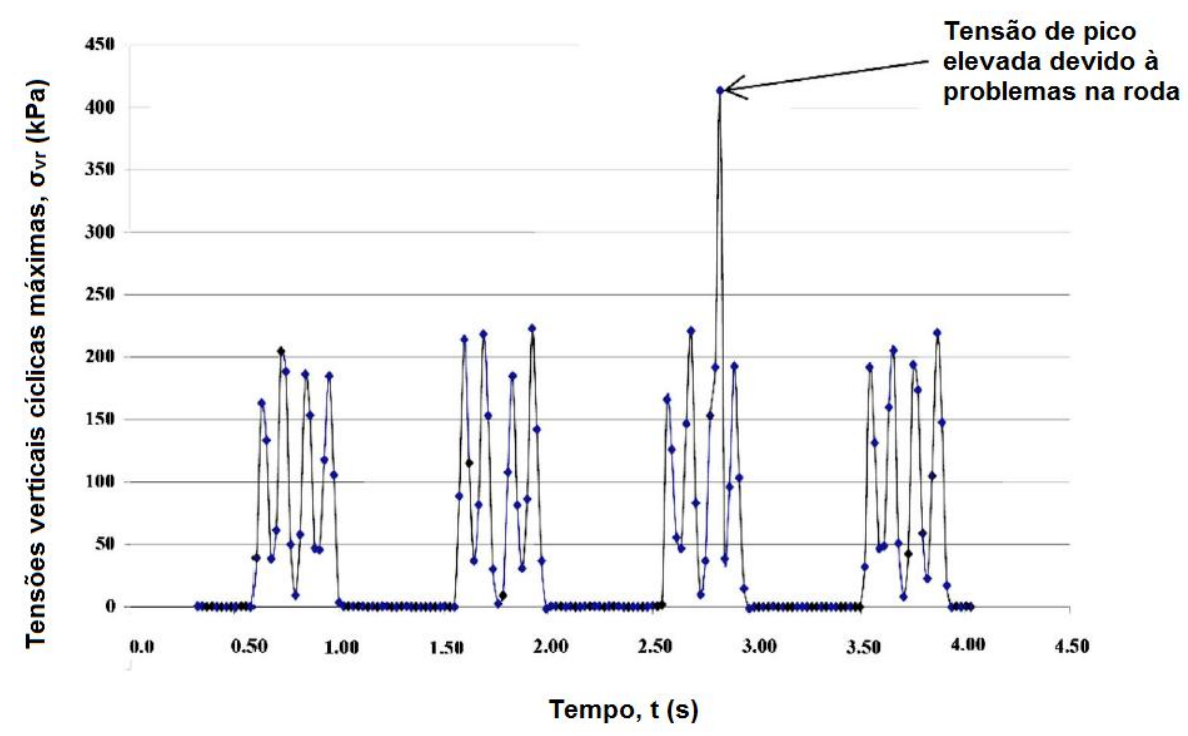

Figura 12 - Tensões verticais máximas cíclicas transmitidas ao lastro pela passagem de vagões de $100 \mathrm{t}$ (Indraratna et al., 2010a)

Esveld (2001) destaca que a tensão de contato máxima entre dormente e lastro é aproximadamente de $500 \mathrm{kPa}$. Atalar et al. (2001) estimam que, para um trem de passageiros com velocidades próximas de $385 \mathrm{~km} / \mathrm{h}$, a tensão máxima é algo em torno de $480 \mathrm{kPa}$. Indraratna et al. (2011), relatam que, em medidas de laboratório e campo realizadas pela Universidade de Wollongong (Austrália), a tensão medida abaixo do dormente é algo em torno de 350-400 kPa, para trens de carga.

Quanto às tensões laterais, alguns autores, por meio de estudos em campo e ensaios de laboratório, obtiveram diversos resultados para estas tensões que atuam na camada de lastro. Raymond e Davies (1978) indicaram que estas tensões dificilmente serão superiores a $140 \mathrm{kPa}$. Selig e Alva-Hurtado (1982) verificaram que a pressão de confinamento de lastros na direção perpendicular ao trilho varia de 5 a $40 \mathrm{kPa}$, valores obtidos por meio de estimativas de coeficientes geotécnicos. Em ensaios box tests, realizados por Selig e Waters (1994), verificou-se que a pressão de confinamento variava entre 18 e $60 \mathrm{kPa}$. Nos primeiros ciclos ocorria a maior variação, algo em torno de $6 \mathrm{kPa}$, entre 0 instante de carregamento e descarregamento (Figura 13). 


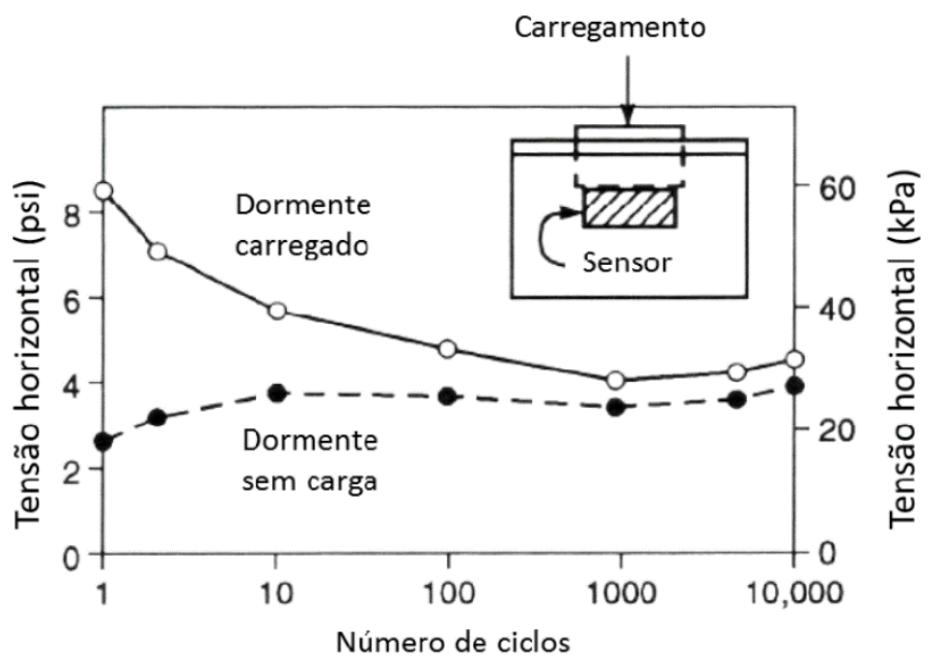

Figura 13 - Tensões horizontais medidas em ensaios de box tests (Selig e Waters, 1994)

Indraratna et al. (2010a), na mesma pesquisa realizada no trecho experimental em Bulli, também relataram medições para estas tensões horizontais, evidenciando a sua variação de acordo com o carregamento. Para um trem de passageiros (20,5 t/eixo), a tensão horizontal é apenas a metade quando comparada com a passagem de um trem de carga (25 t/eixo), como mostrado anteriormente na Figura 11. As medições foram realizadas, no eixo do trilho, em períodos próximos, garantindo que a via estava nas mesmas condições quando a passagem dos dois tipos de trem ocorreu.

\subsection{LASTRO}

Como comentado anteriormente e destacado pelo manual da AREMA (2009), o lastro possui várias funções, dentre as mais importantes ressaltam-se: garantir o suporte uniforme para os trilhos e dormentes, distribuição das cargas de forma homogênea para os materiais subjacentes, prover a drenagem, e garantir o restauro da geometria da via por meio das operações de manutenção.

Conforme Indraratna e Salim (2005), o lastro é geralmente composto de agregados extraídos de jazidas de rocha de alta qualidade, em geral pedreiras de rochas ígneas ou metamórficas. Em alguns casos, para trens de passageiros leves, rochas sedimentares também podem ser usadas. A utilização de rocha britada angular, livre de partículas finas e impurezas, com graduação adequada, dura e densa é recomendada para uso em camada de lastro, pois estas qualidades proverão, entre 
outros fatores, a drenagem, o intertravamento, o mínimo desgaste e a estabilização da via em diferentes condições ambientais e de carregamento.

Não há especificação universal para o lastro, no que diz respeito às propriedades índices do material que irão proporcionar o desempenho ótimo da via, devido a imensa variedade de materiais, carregamentos e condições ambientais (INDRARATNA; SALIM, 2005). Desta forma, as diversas ferrovias pelo mundo requerem estudos aprofundados sobre os materiais utilizados na subestrutura. $A$ fonte de material (rocha-mãe) varia de local para local, dependendo da qualidade e disponibilidade da rocha, regulamentação ambiental e questões econômicas (SELIG; WATERS, 1994; AREMA, 2009).

Uma grande variedade de rochas como basalto, calcário, granito, dolomito, riolito, gnaisse e quartzito são utilizadas como lastro em todo o mundo. Rochas como arenito não são aconselhadas para uso em lastro ferroviário, pois são incapazes de suportar ciclos de molhagem e elevadas cargas cíclicas. Materiais reciclados como escória de alto-forno têm sido utilizados, mas a sua capacidade de carga não pode ser comparada a materiais extraídos de rocha natural (INDRARATNA et al., 2011).

O lastro, composto por rocha britada, é um tipo de material de comportamento granular que é bem documentado na literatura. As experiências que vêm sendo passadas de estudos do lastro em campo e laboratório (Shenton, 1975; Raymond; Williams, 1978; Alva-Hurtado; Selig, 1981; Alva-Hurtado et al., 1981; Diyaljee, 1987; Selig; Waters, 1994; Esveld, 2001; Ionescu, 2004; Indraratna; Salim, 2005) mostram que a progressiva deterioração do material de lastro causada pelo tráfego, ciclos de manutenção (processo de socaria), intrusão de materiais externos (como o derramamento de minério e a infiltração de materiais subjacentes) e a precariedade na drenagem, diminuem muito o desempenho da via e aceleram cada vez mais o processo de desgaste da estrutura. A resposta do lastro contaminado, com relação à resiliência, é altamente dependente dos tipos de materiais contaminantes, quantidade de contaminação e falta de drenagem, tornando a via mais rígida ou não. 


\subsubsection{Propriedades e especificações}

A fim de cumprir suas funções satisfatoriamente, o material de lastro deve estar em conformidade com determinadas características, tais como: tamanho de agregado, forma, graduação, rugosidade da superfície, densidade, resistência, dureza, resistência ao atrito, desgaste e composição mineral. Para garantir um lastro de boa qualidade deve-se ter o devido cuidado com a exploração da lavra, necessitando-se ainda testar o material durante e após processo de fabricação na pedreira.

Como visto, os interesses estão principalmente focados em propriedades mecânicas e dimensionais. Dentro deste contexto, vários padrões e especificações foram feitos por diferentes organizações ferroviárias em todo o mundo para atender às necessidades de seus projetos. Uma visão geral de algumas das principais especificações para o lastro ferroviário será descrita nos próximos parágrafos.

A granulometria de um lastro é um fator primordial para a estabilidade e segurança e da via férrea. Sendo assim, ao se optar pela utilização de uma determinada graduação, deve-se considerar que esta deverá apresentar duas características principais: (i) elevada resistência ao cisalhamento, para proporcionar uma maior estabilidade e redução nas deformações; (ii) alta permeabilidade, para proporcionar uma drenagem adequada e, assim, dissipar o excesso de poro pressão que aumenta as tensões efetivas (INDRARATNA; SALIM, 2005). No entanto, cada uma destas características é obtida com granulometrias diferentes, onde a elevada resistência ao cisalhamento pediria uma distribuição granulométrica do tipo "bem graduada", enquanto a alta permeabilidade seria alcançada com uma granulometria do tipo "mal graduada" ou uniforme. Tais características são contraditórias, onde a maior resistência ao cisalhamento e estabilidade do lastro é obtida em detrimento da capacidade de drenagem (INDRARATNA et al., 2011). Neste sentido, Raymond e Diyaljee (1979); Lackenby et al. (2003); Indraratna et al. (2011) apontaram que a graduação de um lastro precisaria de um equilíbrio entre os dois extremos citados.

Sabe-se que distribuições bem graduadas de lastro resultam em menores deformações que curvas uniformes, atingindo maior densificação e maior resistência ao cisalhamento, além de diminuírem a interpenetração de materiais nas camadas subjacentes (sublastro e subleito), pois os espaços vazios da camada de lastro já 
estão preenchidos por agregados menores (Raymond, 1985). Selig e Waters (1994) relatam que curvas bem distribuídas estendem a vida útil do lastro e reduzem a taxa de deformação da via permanente. Por outro lado, este tipo de granulometria faz com que a permeabilidade seja reduzida e o controle de campo de distribuições bem graduadas é mais difícil, por conta da possibilidade de segregação do material durante o transporte.

No Brasil, a norma ABNT NBR 5564 (2011) estabelece, dentre outros aspectos, quais devem ser as características granulométricas do lastro de rocha britada. A especificação cita que a camada de lastro deve permitir o escoamento da água, devendo-se então evitar o excesso de finos que, além de reduzirem sua permeabilidade, também causam aumento de sua rigidez. Nesta norma são estabelecidos dois padrões granulométricos, Padrão A e $B$, que se referem a lastro para aplicação em linhas principais e em linhas de pátios, respectivamente (Figura 14).

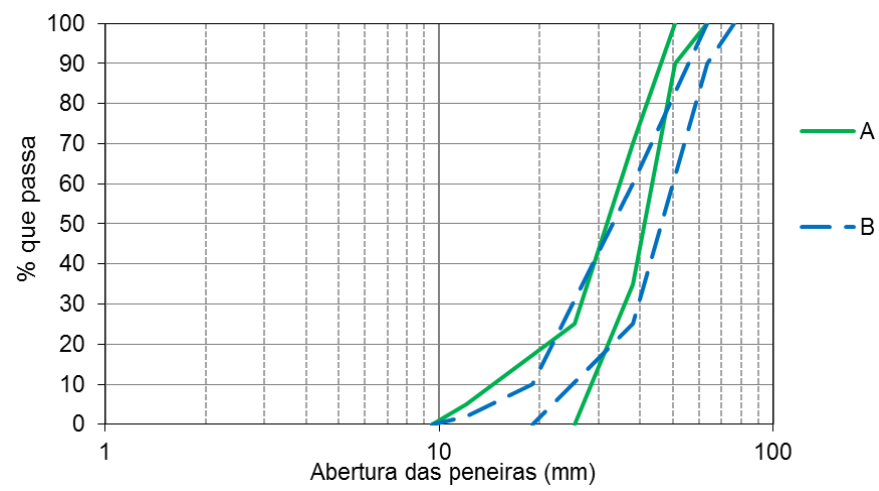

Figura 14 - Distribuições granulométricas - ABNT NBR 5564

O manual AREMA (2009) é a especificação corrente nos Estados Unidos e recomenda que os materiais utilizados como lastro devem ser testados pelo grupo de peneiras de acordo com a norma ASTM E 11 (2009). O manual norte-americano estabelece diferentes composições granulométricas, como mostra a Figura 15, cujas graduações $n^{\circ}$ s $24,25,3,4$ e 4 são recomendadas para serem empregadas em lastro de linhas principais, enquanto a 5 e a 57 são recomendadas para aplicação em linhas secundárias. Cabe mencionar que, em todas as faixas, o limite máximo de partículas passantes na peneira $\mathrm{n}^{\circ} 200(0,075 \mathrm{~mm})$ deve ser menor que $1 \%$. Ademais, deve-se atentar ainda para o fato de que a graduação 25 possui um 
coeficiente de uniformidade $\left(C_{u}{ }^{4}\right)$ maior que 3,0 e representa, dentre as outras faixas, a mais bem graduada.
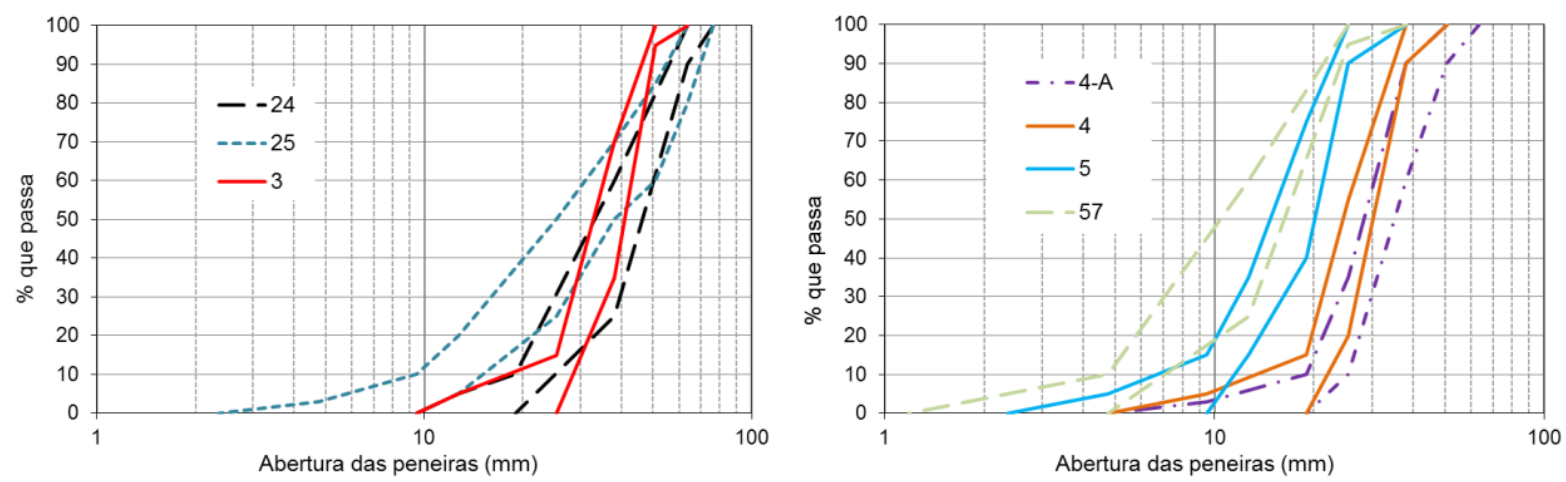

Figura 15 - Distribuições granulométricas - AREMA (2009)

$\mathrm{Na}$ Austrália, várias distribuições granulométricas são adotadas por diferentes órgãos ferroviários como a Rail Infrastructure Corporation (RIC) e a Queensland Rail, por exemplo. Tais curvas são baseadas nos limites estabelecidos pela normalização australiana para lastro ferroviário AS 2758.7 (1996), e estão apresentadas na Figura 16. Cabe mencionar que esta especificação determina ainda que a porcentagem máxima de material fino (passante na peneira $0,075 \mathrm{~mm}$ ) deve ser $1 \%$ (INDRARATNA et al., 2011).

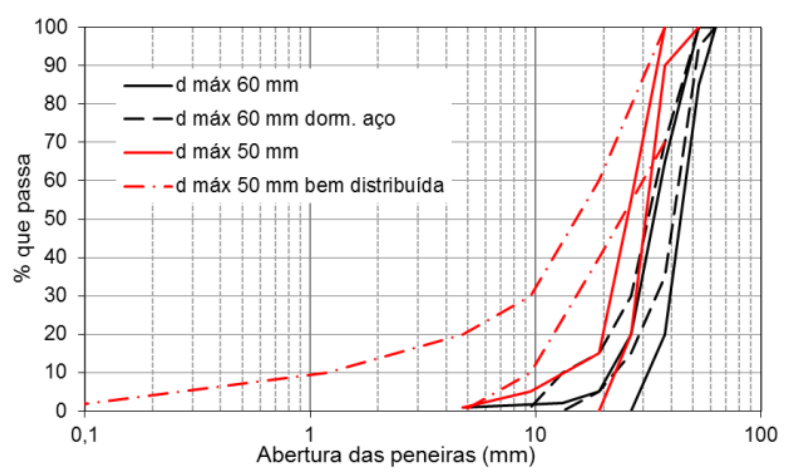

(a)

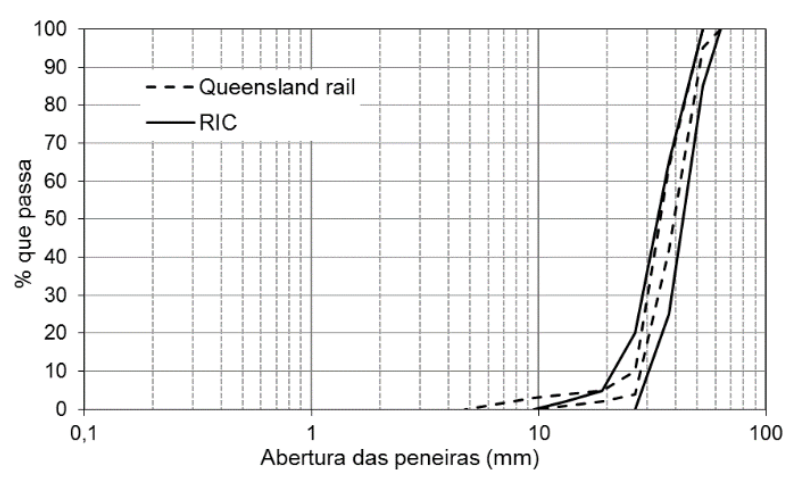

(b)

Figura 16 - Distribuições granulométricas - (a) AS 2758.7; (b) RIC e Queensland Rail (Indraratna et al., 2011)

\footnotetext{
${ }^{4}$ Definição: $C_{u}=\frac{\% \text { pass.D60 }}{\% \text { pass.D10 }}$
} 
Estão representadas na Figura 17 as diferentes faixas granulométricas normatizadas para lastro ferroviário na Europa, segundo a norma EN 13450 (2002), assim como a distribuição granulométrica francesa adotada pela SNCF (Société Nationale des Chemins de fer Français), incluindo seus limites de composição considerados excelente, além da granulometria típica de lastro da British Railways, da Inglaterra. Em termos de especificações, para as ferrovias francesas os agregados maiores que $63 \mathrm{~mm}$ e menores que $16 \mathrm{~mm}$ devem representar no máximo $2 \%$. Na British Railways, a graduação é muito uniforme, com coeficiente de uniformidade $\left(C_{u}\right)$ de 1,4 (muito menor que a maioria das outras especificações). Percebe-se também pela Figura 17, que a especificação europeia limita todas as suas graduações dentro uma faixa restrita, fazendo com que todas as curvas possuam coeficientes de uniformidades próximos.

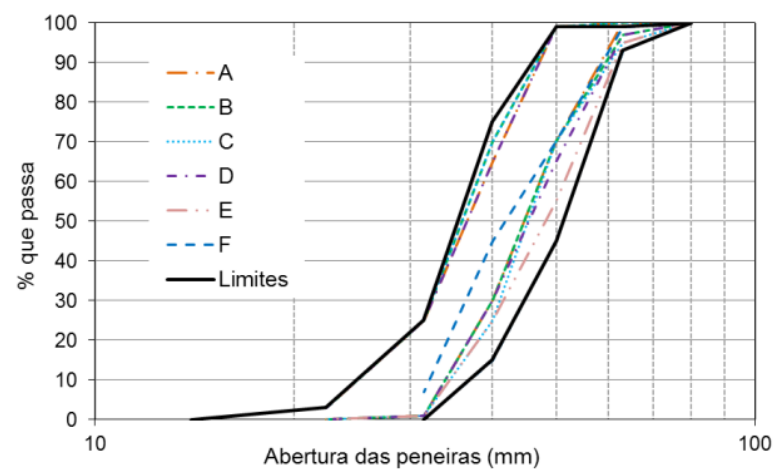

(a)

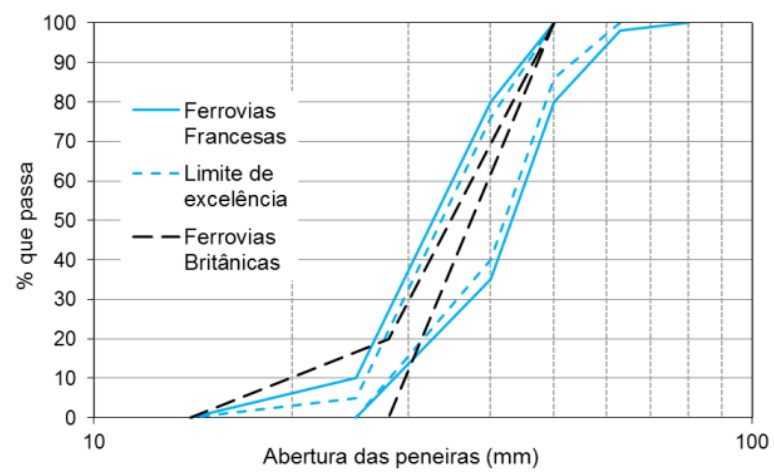

(b)

Figura 17 - Distribuições granulométricas (a) EN 13450 (2002); (b) British Railways; SNCF (Profillidis, 2006)

Para fins de comparação, a Tabela 1 aponta quais são as exigências nas especificações ABNT e AREMA, para diferentes propriedades do material de lastro. Cabe mencionar que o manual AREMA (2009) especifica diferentes limites em função do tipo de composição mineralógica do material a ser utilizado no lastro (granito, basalto, quartzito, calcário, calcário dolomítico, escória de alto forno e escória de aciaria), já a normatização brasileira cita apenas que o lastro ferroviário deve ser constituído de fragmentos britados extraídos de rocha dura e sã, reconhecida como de característica petrográfica própria ao uso em lastro de via férrea. 
Tabela 1 - Limite de aceitabilidade para diversas propriedades do lastro - AREMA (para granito) e ABNT

\begin{tabular}{|c|c|c|}
\hline \multirow{2}{*}{ Parâmetro } & ABNT & AREMA \\
\hline & \multicolumn{2}{|c|}{ Limites } \\
\hline Partículas não cúbicas & máx. $15,0 \%$ & - \\
\hline Partículas lamelares e/ou alongadas & - & máx. 5,0\% \\
\hline Forma das partículas & Cúbica & Cúbica \\
\hline Porcentagem passante na peneira $n^{\circ} 200$ & - & máx.1,0\% \\
\hline Material pulverulento & máx. $1,0 \%$ & - \\
\hline Massa específica aparente & mín. 2500 kg/m³ & - \\
\hline Densidade & - & mín. 2,60 \\
\hline Absorção de água & máx. 0,8\% & máx. $1,0 \%$ \\
\hline Porosidade aparente & mín. $1,5 \%$ & - \\
\hline $\begin{array}{l}\text { Resistência à intempérie }{ }^{\mathrm{a}} \text { (ABNT)/ Sanidade } \\
\text { (AREMA) }\end{array}$ & máx. $10,0 \%{ }^{c}$ & máx. $5,0 \%{ }^{d}$ \\
\hline Resistência à compressão axial & mín. $100 \mathrm{MPa}$ & - \\
\hline $\begin{array}{l}\text { Resistência ao choque (Índice de tenacidade Treton } \\
\text { máximo) }\end{array}$ & máx. 25,0\% & - \\
\hline Resistência ao desgaste Los Angeles & máx. 30,0\% & máx. 35,0\% \\
\hline Teor de fragmentos macios e friáveis ${ }^{a, b}$ & máx. 5,0\% & - \\
\hline Torrões de argilab $^{b}$ & máx. $0,5 \%$ & máx. 0,5\% \\
\hline Limite de massa unitária no estado solto & $1,25 \mathrm{~g} / \mathrm{cm}^{3}$ & - \\
\hline
\end{tabular}

(a) Verificação opcional, segundo a ABNT

(b) A AREMA considera a avaliação de torrões de argila e de partículas friáveis, em conjunto

(c) Após 40 ciclos

(d) Após 5 ciclos

\subsubsection{Comportamento Mecânico}

Sob carregamento cíclico, as deformações de materiais granulares são divididas em deformações elásticas (recuperáveis) e deformações plásticas (permanentes) (LEKARP et al., 2000), como apresentado na Figura 18. Tanto deformações elásticas quanto plásticas são em grande parte, dependentes da relação entre a tensão aplicada e da máxima tensão que o material pode ser submetido. $O$ comportamento elasto-plástico do lastro ferroviário caracteriza-se como a acumulação gradual de deformação permanente a cada aplicação de carga. A taxa de acumulação da deformação plástica geralmente diminui à medida que o número de ciclos aplicados aumenta (SELIG; WATERS, 1994). 


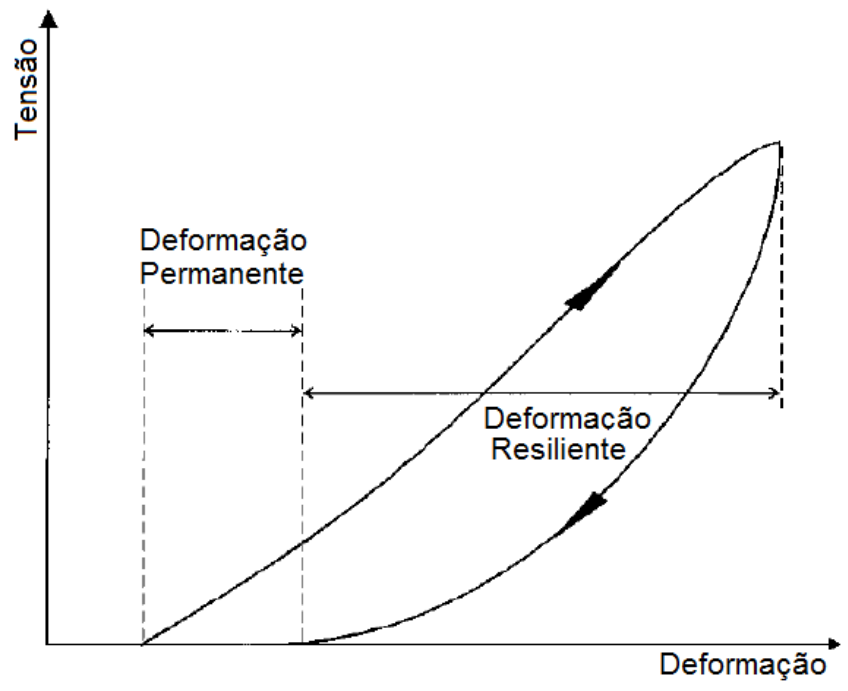

Figura 18 - Deformações de materiais granulares durante um ciclo de aplicação de carga (Lekarp et al., 2000)

De acordo com Lekarp et al. (2000), o comportamento elasto-plástico de materiais granulares depende de vários fatores que podem ser relacionados em duas categorias: a primeira relativa ao material e outra caracterizada pelo carregamento imposto. As principais propriedades que influenciam o comportamento do lastro quanto ao material são: densidade, distribuição granulométrica, porcentagem de finos, teor de umidade, tamanho máximo dos agregados, tipo de agregado, forma dos agregados. Com relação ao carregamento os principais elementos são: nível de tensões, história de tensões, número de ciclos, frequência, duração e sequência de carregamento.

\subsubsection{Comportamento Resiliente}

Hveem e Carmany (1948) e Hveem (1955) introduziram o conceito de resiliência e destacaram a importância deste parâmetro em pavimentos, particularmente na compreensão do trincamento por fadiga de revestimento asfáltico. O módulo de resiliência (MR) de um material é definido como a tensão-desvio (diferença entre a tensão principal maior pela menor), sob carregamento cíclico, dividida pela deformação específica axial resiliente durante o carregamento no ensaio triaxial (Seed et al., 1962), definido na Equação 2. 


$$
M R=\frac{\left(\sigma_{1}-\sigma_{3}\right)}{\varepsilon_{a}}
$$

Onde:

$$
\begin{gathered}
\sigma_{1}=\text { Tensão principal maior } \\
\sigma_{3}=\text { Tensão principal menor } \\
\varepsilon_{a}=\text { Deformação específica axial resiliente }
\end{gathered}
$$

No caso do lastro de ferrovias, o comportamento resiliente é importante para compreender as características dos materiais da subestrutura (subleito, sublastro e lastro) que afetam a degradação e a deformação da via (BATHURST; RAYMOND, 1987).

O módulo de resiliência do lastro geralmente aumenta gradualmente com o número de aplicações de carga, devido ao enrijecimento pela acomodação do material (SEVI, 2008; INDRARATNA; SALIM, 2005). Em determinados níveis de tensão, o módulo de resiliência finalmente chega a um valor aproximadamente constante após certo número de aplicações de carga e o material comporta-se de maneira quase puramente elástica, como mostrado na Figura 19 (SELIG; WATERS, 1994). Kalcheff e Hicks (1973) indicam que algumas centenas de ciclos são necessárias para esta estabilização, enquanto que Morgan (1966) relata que somente em alguns milhares de ciclos esta estabilização ocorre. 


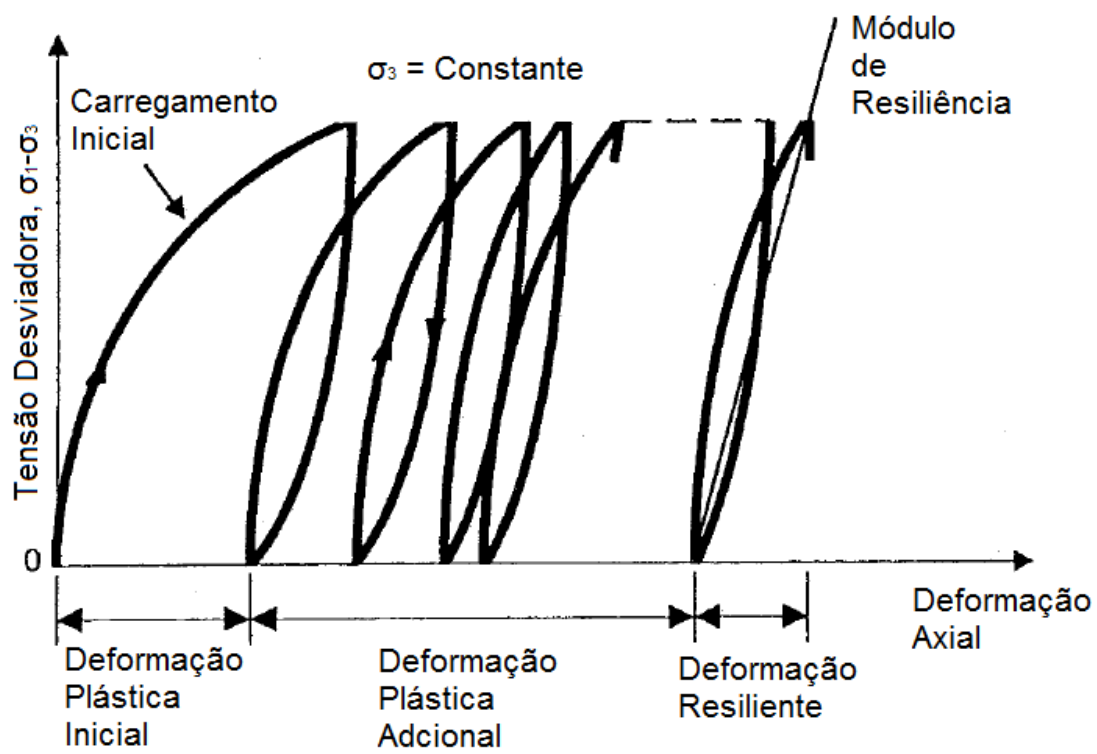

Figura 19 - Representação da curva tensão/deformação de um ensaio triaxial drenado de carga cíclica com material de lastro (Selig e Waters, 1994)

\subsubsection{Deformação Permanente}

A camada de lastro depende da história de carregamento, em que o incremento de deformação plástica diminui geralmente com o aumento de ciclos, para uma razão de tensões específica (LIM, 2004). Quando o lastro é submetido abaixo desta relação de tensões, as deformações plásticas se mantêm estabilizadas. Entretanto, quando a relação de tensões é aumentada para níveis nunca antes aplicados, a deformação plástica continua se acumulando até atingir um novo ponto de equilíbrio ou alcançar a ruptura (AURSUDKIJ, 2007).

Segundo Sevi (2008), existem três formas para a previsão do acúmulo de deformação plástica em materiais granulares submetidos a carregamento cíclico. Estas previsões são geralmente divididas de três formas: a primeira relaciona a deformação permanente ao número de aplicações de cargas, a segunda ao estado de tensões do material e a terceira utiliza a teoria do Shakedown. As previsões que relacionam as deformações permanentes com base no número de aplicações de carga se separam em situações onde a carga repetida pode ser considerada de menor ou maior magnitude. O método que utiliza o estado de tensões relaciona resultados de ensaios de carga estática (monotônicos) com a magnitude do carregamento repetido para prever deformações plásticas. O conceito shakedown prevê que, no caso de uma carga cíclica baixa, incrementos de deformação plástica 
do material granular diminuem para um valor assimptótico, enquanto que no caso de elevadas tensões cíclicas, o método prediz um efeito de ruptura, onde as deformações plásticas persistem e a amostra é rapidamente destruída (colapso).

\section{Teoria do Shakedown}

Collins e Boulbibane (2000) explicam que o conceito do shakedown tem sido utilizado frequentemente para descrever as características de deformação plástica do material de lastro submetido ao carregamento cíclico. Neste caso, quatro zonas podem ser caracterizadas, de acordo com diferentes níveis de tensão, Figura 20.

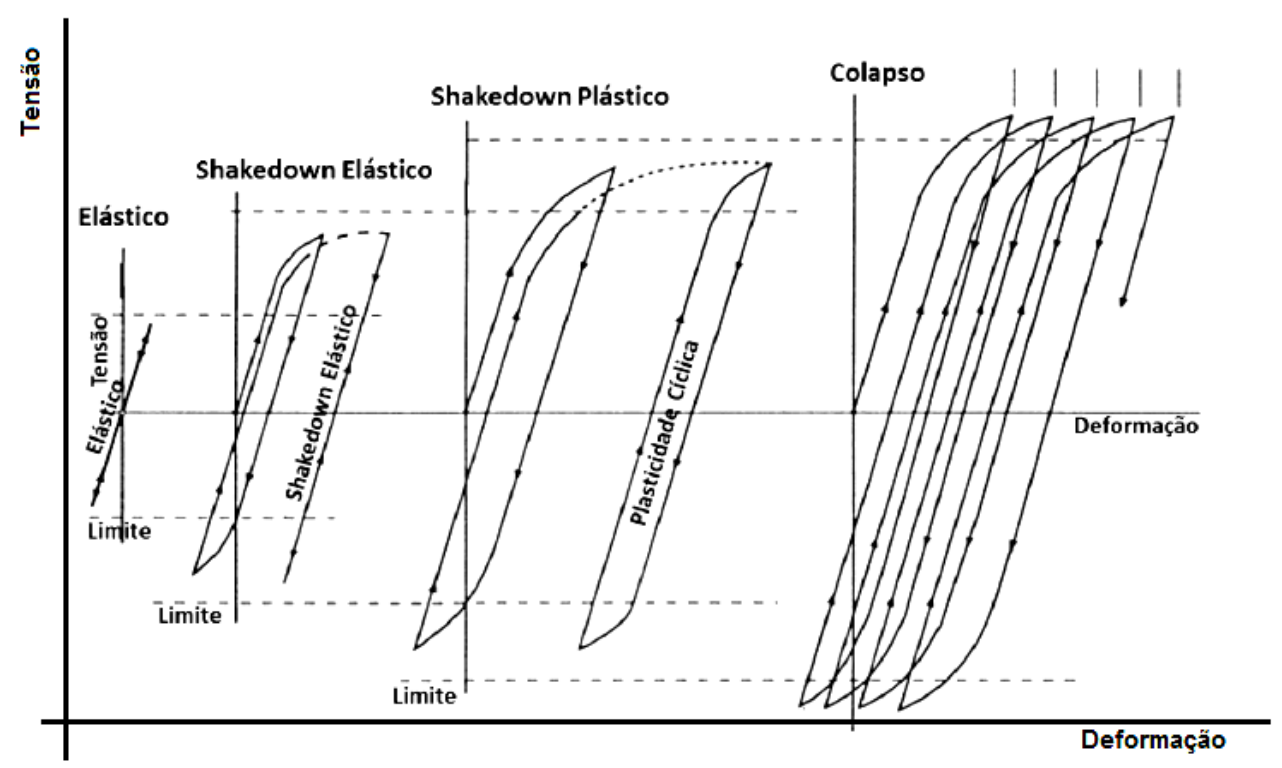

Figura 20 - Quatro tipos do comportamento elasto-plástico de materiais granulares submetidos à carga cíclica (Johnson, 1986)

(1) - Elástica: Nesta zona as tensões aplicadas não são suficientemente elevadas ao ponto de provocar reacomodação ou deformações plásticas, ou seja, todas as deformações sofridas pelo material são recuperáveis quando cessado o carregamento.

(2) - Shakedown elástico: Nesta zona o material sofre deformações plásticas até um número finito de aplicações de carga durante um período inicial de rearranjo. Em seguida, o material passa a se comportar como elástico, sofrendo apenas deformações recuperáveis. As tensões, para esta condição, são superiores às tensões que provocaram o comportamento elástico. Nesta situação, os agregados atingem uma condição estável de intertravamento, que permite sua estabilidade. 
(3) - Shakedown plástico: No comportamento conhecido como shakedown plástico as tensões são superiores ao limite do shakedown elástico e inferiores às tensões que provocam a ruptura. Neste caso, após a fase inicial de acomodação dos agregados, o material apresenta taxas decrescentes ou constantes de deformação plástica. O limite do shakedown plástico é, portanto, a máxima tensão que provoca uma taxa constante de deformação permanente no material.

(4) - Colapso: Na faixa que corresponde ao colapso, se as tensões ultrapassarem o limite do shakedown plástico, o material acumulará deformações plásticas, crescentes a cada ciclo, até a ruptura.

\subsubsection{Avaliação do comportamento mecânico em campo e laboratório}

A análise do comportamento mecânico da estrutura ferroviária foi realizada por diversos autores, tanto em campo como em laboratório. Selig (1975, 1980), Anderson e Rose (2008), Yang et al. (2009), Indraratna et al. (2010) são alguns exemplos de pesquisadores que se utilizaram de trechos experimentais para estudar o comportamento elasto-plástico da camada de lastro.

No Brasil, destacam-se os trabalhos experimentais de campo realizados por Muniz (2002) e Spada (2003) que tratam de uma abordagem ao comportamento tensão-deformação da via férrea e a um sistema de gerência aplicado à manutenção da via permanente, respectivamente.

A Figura 21 mostra detalhes de uma parte da instrumentação realizada por Anderson e Rose (2008) em um trecho experimental de ferrovia de tráfego pesado localizado entre as cidades norte-americanas de Cincinnati (Ohio) e Atlanta (Georgia). Estudo similar ao que será abordado por esta pesquisa no Capítulo 3, apresentou bons resultados de análise dinâmica, tanto de deslocamento quanto de tensões na via, medidas em interfaces críticas. As deflexões sob as cargas dinâmicas dos vagões foram registradas usando transdutores de deslocamento linear variável (LVDT). Uma dificuldade ao uso de LVDT's para medir deslocamentos na via foi estabelecer um ponto fixo de referência, sem que as leituras do aparelho sofressem influência do ruído causado pela passagem do trem. A Figura 22 apresenta algumas das medidas obtidas em trecho com espessura de lastro de 
$450 \mathrm{~mm}$, sublastro asfáltico de $125 \mathrm{~mm}$ e dormente de madeira (ANDERSON; ROSE, 2008).
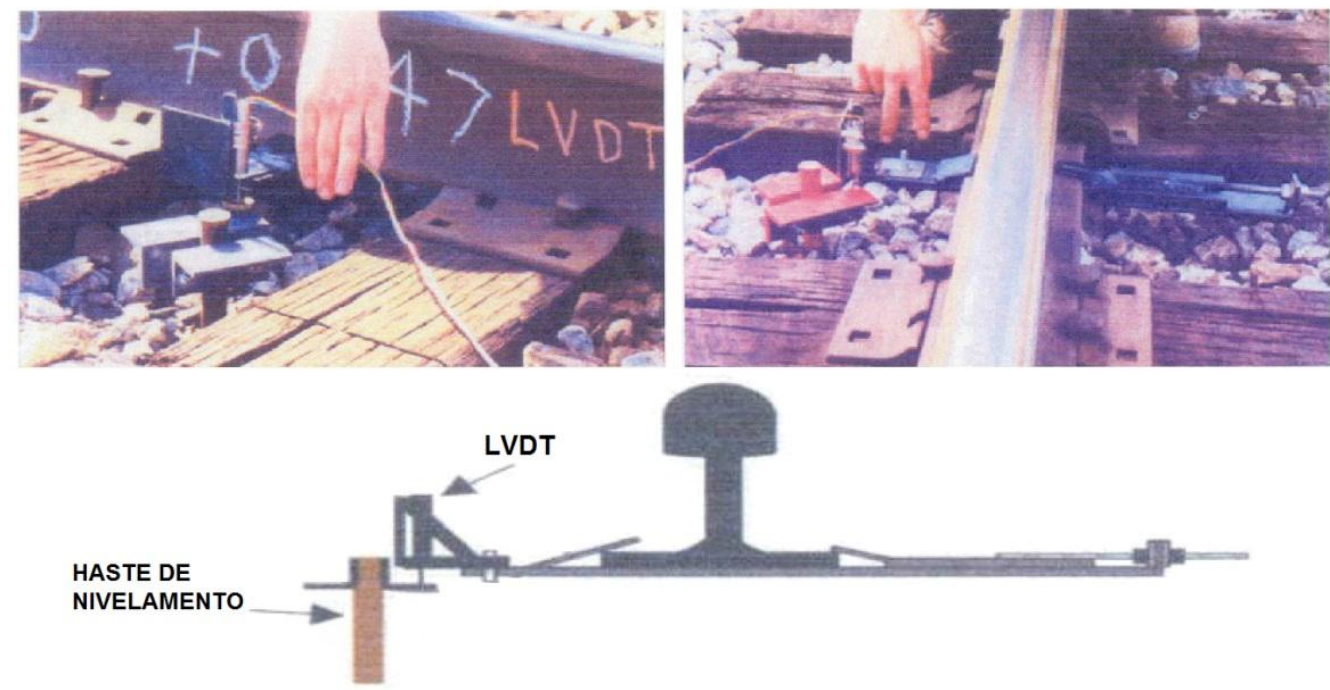

Figura 21 - Detalhes da instalação de LVDT para medidas de deflexão (Anderson e Rose, 2008)

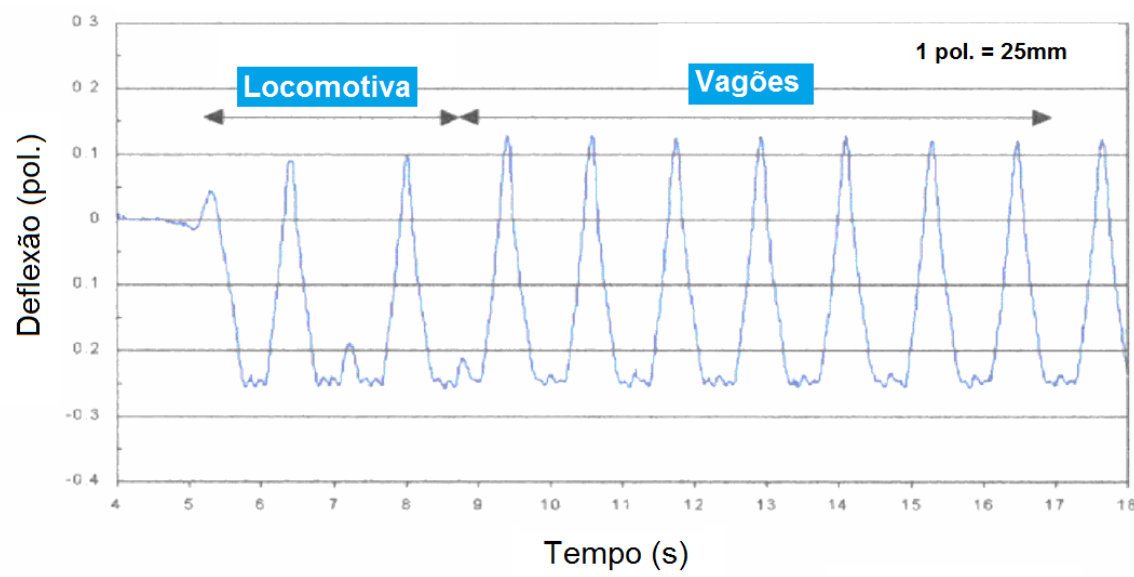

Figura 22 - Medidas de deflexão por LVDT realizada em trecho experimental nos EUA (Anderson e Rose, 2008)

Em laboratório, o comportamento deformacional de materiais granulares é geralmente investigado por meio de ensaios triaxiais, conforme estudos de AlvaHurtado et al. (1981); Stewart (1986); Diyaljee (1987); Indraratna et al. (1997); Nalsund (2010). Segundo Indraratna et al. (1998), o equipamento de ensaio triaxial é um dos mais versáteis e úteis para a determinação das propriedades de resistência e deformação de materiais geotécnicos. Outro equipamento laboratorial desenvolvido para a análise do lastro é o ensaio em câmara prismática (Box test), 
com estudos realizados, por exemplo, por Selig e Waters (1994); Han e Selig (1997); Anderson e Key (2000); Ebrahimi et al. (2010).

No ensaio triaxial, a aplicação da carga vertical é feita através de uma célula de carga e o confinamento de corpos de prova cilíndricos (envolvidos por uma membrana) é obtido por meio de um fluido (água, ar ou óleo) sob pressão. A Figura 23 mostra uma representação esquemática do equipamento utilizado para ensaios triaxiais, como o do LTP-PTR-EPUSP, onde foi desenvolvida a presente pesquisa. Como a tensão de confinamento é aplicada por um fluido, a tensão principal intermediária $\left(\sigma_{2}\right)$ é igual à tensão principal menor $\left(\sigma_{3}\right)$, recebendo o nome de tensão confinante. A tensão principal maior $\left(\sigma_{1}\right)$ é então obtida pela soma da tensão confinante $\left(\sigma_{c}\right)$ com a tensão imposta pelo pistão $\left(\sigma_{d}\right)$. Uma representação destas tensões é ilustrada também na Figura 23.

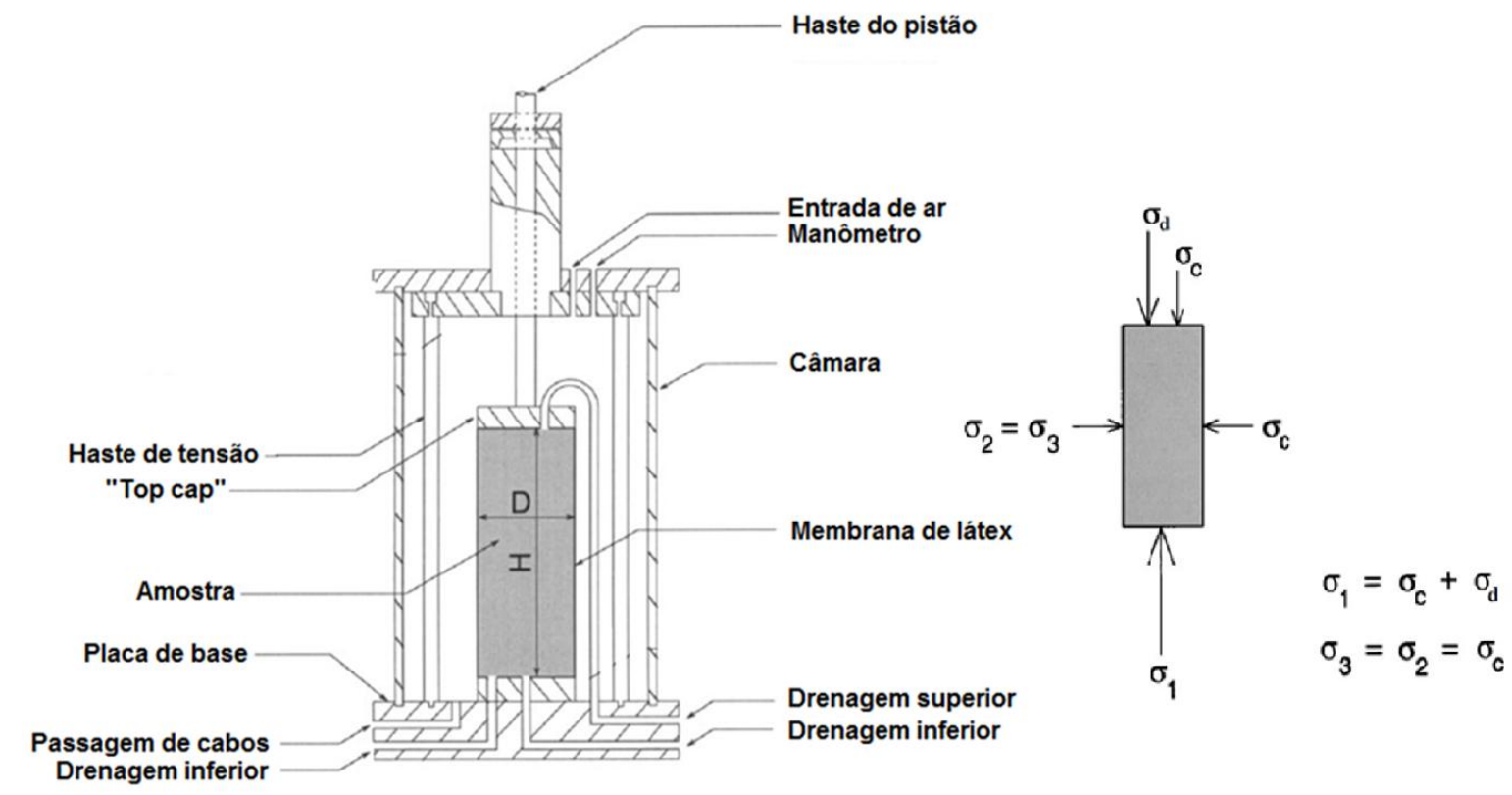

Figura 23 - Componentes de equipamento de ensaio triaxial e estado de tensão assimétrico em um teste convencional (Suiker et al., 2005)

Para o estudo de lastros ferroviários em laboratório, a maior dificuldade encontrada é relativa à dimensão do material, cujos diâmetros máximos dos agregados chegam a ser da ordem de $63,5 \mathrm{~mm}$, impedindo a utilização do equipamento triaxial convencional que é usualmente empregado para solos e outros materiais granulares utilizados no meio rodoviário (menor dimensão). Outro fator que dificulta ensaios 
destes tipos e materiais é a manipulação de amostras de grandes dimensões, sendo necessário o uso de equipamentos não habituais nos laboratórios.

A fim de contornar este problema, duas abordagens são utilizadas: (i) ensaios triaxiais de verdadeira grandeza (grande escala); ou (ii) translação da curva granulométrica para ensaiar o material em escala reduzida (decalada), porém ressalta-se que resultados divergentes entre amostras decaladas e de grandes dimensões foram evidenciadas por Indraratna et al. (1998). Desta forma, a realização de ensaios em verdadeira grandeza é importante, pois os corpos de prova com material de lastro são preparados com curvas granulométricas similares àquelas reais de campo e são submetidos a tensões características de ferrovias.

\section{Grande escala}

De acordo com Skoglund (2002), os valores típicos da relação D/dmáx (onde: $\mathrm{D}$ = diâmetro do corpo de prova; e $d_{\text {máx }}=$ diâmetro máximo do agregado) variam de 5 a 7 , demonstrando que o diâmetro do corpo de prova deve ser considerável para que haja uma distribuição suficientemente representativa de agregados ao longo de sua dimensão. Este cuidado permite que o comportamento do conjunto de agregados seja testado como um todo, e não de um grupo reduzido, até não representativo, do conjunto integral.

Outros autores como, por exemplo, Suiker et al. (2005) e Sevi (2008) trabalharam com ensaios em grande escala no âmbito ferroviário e recomendam que o diâmetro do maior agregado seja menor que $1 / 6$ do diâmetro do corpo de prova, para que os efeitos do equipamento possam ser desprezados. Tal relação também está descrita na norma ASTM D5311 (2004) para solos; para que as dimensões do corpo de prova sejam consideradas adequadas para ensaios de módulo de resiliência, a AASHTO T292-91 recomenda que 90\% dos agregados tenham diâmetro máximo seis vezes menor do que o diâmetro dos corpos de prova, e que todos os agregados tenham diâmetro máximo inferior a um quarto do diâmetro do corpo de prova. Por outro lado, considerando a relação entre H/D (altura e diâmetro), Bishop e Green (1965) recomendam que a proporção seja de 2. Neste caso, os autores relatam que este valor é ideal para eliminar o efeito de atrito nas extremidades da amostra. 
Em função das dimensões citadas, poucos são os laboratórios no mundo que conseguem realizar estes ensaios, porém não somente devido ao tamanho graúdo dos agregados, mas também pela grande capacidade de carga necessária ao equipamento que impõe os carregamentos. Ensaios com lastros ferroviários, principalmente aqueles que serão submetidos a tráfego de trens carga, requerem equipamento de reação (atuador) com capacidade de carga elevada, visto que existem ferrovias que operam com carregamentos, por exemplo, que chegam a 40 toneladas/eixo, como na Austrália. Além da robustez necessária à prensa atuadora, é de fundamental importância que o equipamento esteja calibrado e execute a simulação dos ciclos de carregamento de forma precisa, pois sob elevadas frequências, diversos ensaios de grande escala já evidenciaram instabilidade (AURSUDKIJ, 2007; FORTUNATO, 2005).

A Tabela 2 mostra alguns locais onde foram realizados estudos de lastros por meio de ensaios triaxiais de grande escala. Cabe mencionar ainda uma pesquisa nacional em que Malysz (2009) desenvolveu equipamento traiaxial de grande porte (250 mm x $500 \mathrm{~mm}$ ) com o objetivo de avaliar o comportamento mecânico de agregados utilizados como camada de pavimentos. Entretanto, o estudo do lastro ferroviário por meio de equipamento triaxial de grande escala é inexistente no Brasil.

Tabela 2 - Locais onde foram realizados ensaios triaxiais de grande escala em estudos de lastro

\begin{tabular}{cccccc}
\hline Pesquisadores & Ano & $\begin{array}{c}\text { Diâmetro do } \\
\text { equipamento } \\
(\mathrm{mm})\end{array}$ & $\begin{array}{c}\text { Altura do } \\
\text { equipamento } \\
(\mathrm{mm})\end{array}$ & $\begin{array}{c}\mathrm{d}_{\text {máx }} \\
(\mathrm{mm})\end{array}$ & Local \\
\hline Raymond e Diyaljee & 1979 & 230 & 460 & 38 & Canadá \\
\hline Alva-Hurtado et al. & 1981 & 305 & 610 & 30 & EUA \\
\hline Suiker et al. & 2005 & 254 & 645 & 38 & EUA \\
\hline Sekine et al. & 2005 & 300 & 600 & 63,5 & Japão \\
\hline Lackenby et al. & 2007 & 300 & 600 & 53 & Austrália \\
\hline Anderson e Fair & 2008 & 236 & 455 & 50 & Inglaterra \\
\hline Sevi et al. & 2009 & 419 & 864 & 63,5 & EUA \\
\hline Aursudkij et al. & 2009 & 300 & 450 & 50 & Inglaterra \\
\hline Nalsund & 2010 & 300 & 600 & 63 & Noruega \\
\hline Ebrahimi et al. & 2010 & 305 & 610 & 60 & EUA \\
\hline
\end{tabular}


Atualmente ainda não existem ensaios triaxiais normatizados para material de lastro, referentes a módulo de resiliência e deformação permanente, o que leva a uma adaptação do ensaio triaxial empregado para solos granulares, em função da necessidade do pesquisador. Em geral, varia-se a tensão de confinamento $\left(\sigma_{c}\right)$ e a tensão-desvio $\left(\sigma_{d}\right)$ para ensaios de módulo de resiliência, enquanto essas tensões não variam ou variam em poucas combinações no estudo de deformação permanente, cujos resultados são usualmente expressos em função do número de aplicações de carga. Cabe mencionar que quanto ao confinamento de corpos de prova desta dimensão, este pode ser realizado por meio da aplicação de vácuo, como mostram os exemplos da Figura 24.

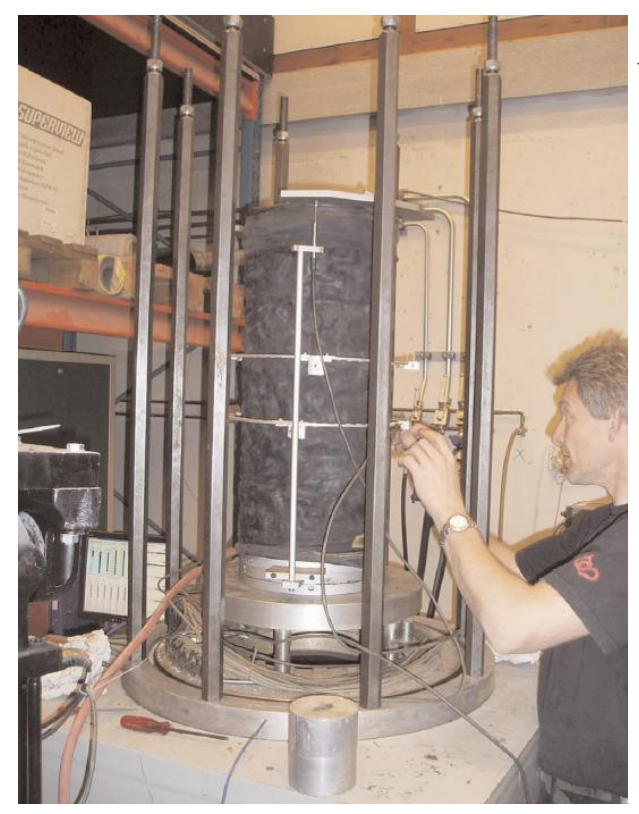

(a)

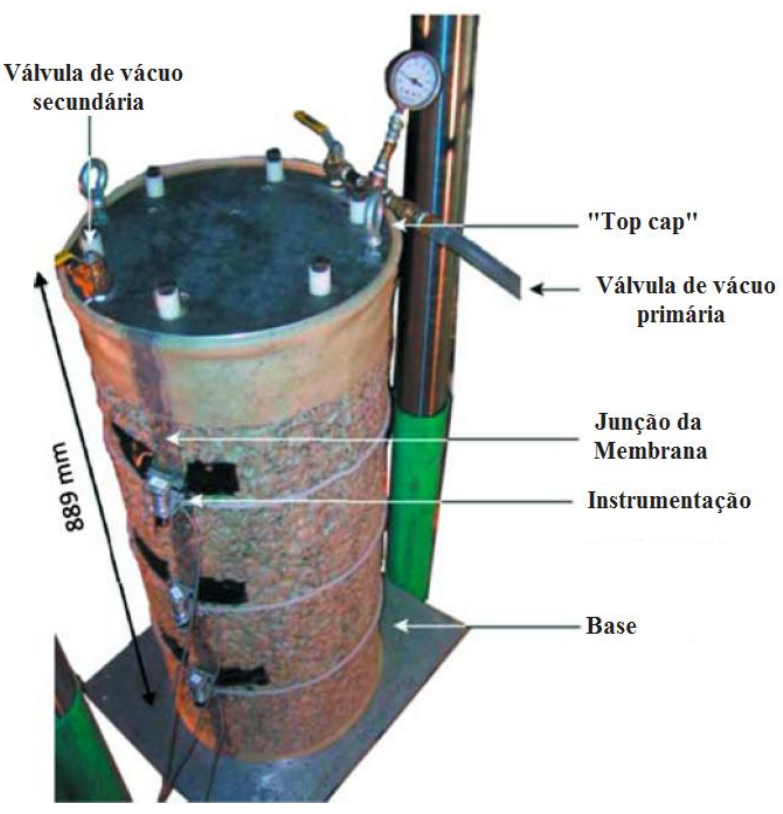

(b)

Figura 24 - Exemplos de ensaios triaxiais em grande escala com confinamento aplicado por vácuo (a) Nalsund, 2010; (b) Sevi, 2009

\section{Escala reduzida}

Na granulometria típica de lastro, os agregados têm dimensão que varia de 30 a $70 \mathrm{~mm}$, fazendo com que haja a necessidade de adoção de ensaios em grande escala para realizar o estudo das propriedades mecânicas destes materiais. Contudo, a manipulação de amostras de grandes dimensões é difícil, devido à utilização de diversos equipamentos não habituais nos laboratórios. Com o objetivo de contornar estas dificuldades e estudar o efeito de diferentes tamanho de agregados, pesquisadores como Lowe (1964), Jernigan (1998) e 
Varadarajan et al. (2003) desenvolveram e utilizaram a graduação paralela (decalada).

Lowe (1964) propôs, para um conjunto de esferas perfeitas, que independentemente do tamanho, tanto as tensões de contato como o índice de vazios de uma amostra inicial poderiam ser representados por uma amostra de menor dimensão. Ou seja, esferas de menores tamanhos poderiam ser utilizadas para o estudo do comportamento mecânico de um conjunto de esferas maiores, se as demais propriedades do material fossem mantidas constantes.

Varadarajan et al. (2003) relataram que existem quatro técnicas utilizadas para redução do tamanho dos agregados de pedra britada, onde a técnica de graduação paralela foi encontrada a mais adequada. O modelo de decalagem de graduação sugere, então, que é possível testar o comportamento mecânico de materiais granulares em escala reduzida. Para que isso seja possível, é necessário que a curva granulométrica do material reduzido seja paralela à curva original, e que os materiais utilizados tenham as mesmas características como mineralogia, forma e rugosidade superficial.

Entretanto, Sevi (2008) realizou ensaios triaxiais para três curvas granulométricas paralelas. Os conjuntos de agregados menores apresentaram deformações permanentes axiais e volumétricas, além de módulos de resiliência, diferentes da curva original.

Segundo Klincevicius (2011), estudos para a viabilidade de métodos de redução de escala foram geralmente realizados para materiais de enrocamento de barragens, cujo estado de tensões é muito diferente daquele de uma ferrovia. Agregados britados com diferentes tamanhos podem apresentar variações na microestrutura do material, devido ao processo de britagem que sofreram e, com isso, a representatividade fica comprometida. Durante o ensaio com lastro, quando as tensões são suficientes para quebrar os agregados, tais diferenças influenciam no comportamento mecânico, onde a diminuição do tamanho dos agregados alterará o comportamento do conjunto.

Indraratna et al. (1998) acreditam que resultados de ensaios em escala reduzida não são confiáveis para a previsão de parâmetros de deformação. Para eles, é 
necessária a realização de ensaios de verdadeira grandeza, nos quais os corpos de prova são preparados conforme lastros em campo, sendo submetidos a tensões características de ferrovias. No entanto, a técnica de decalagem de graduação, sendo válida, contribuiria muito para os estudos de lastros ferroviários, e possibilitaria a realização de ensaios em equipamentos triaxiais convencionais (menor escala).

\subsubsection{Elementos que afetam o comportamento mecânico}

Como já visto anteriormente no item 2.2.2, vários são os fatores que influenciam o comportamento mecânico do lastro, estando estes divididos em dois grupos: (i) material (características individuais dos grãos e do conjunto de grãos) e; (ii) carregamento. Dentre todos os fatores já citados, nos próximos parágrafos estarão destacados apenas os elementos que serão analisados por esta pesquisa, como: distribuição granulométrica, porcentagem de finos (contaminação), teor de umidade, influência da tensão confinante, nível de tensões e número de ciclos.

Com o objetivo de avaliar o efeito da distribuição granulométrica no comportamento mecânico do lastro, Indraratna et al. (2004) realizaram ensaios triaxiais cíclicos, em verdadeira grandeza, com quatro diferentes graduações (Figura 25a). As amostras estavam sujeitas a um confinamento de $45 \mathrm{kPa}$ e tensões axiais cíclicas máximas de $300 \mathrm{kPa}$. Os testes revelaram que as amostras de graduação uniforme obtiveram maiores deformações, tanto volumétrica quanto axial (Figura 25b), enquanto o oposto ocorreu com as outras duas amostras com distribuição bem graduada (que proporcionaram melhor imbricamento, maior resistência ao cisalhamento e menores deformações). No mesmo estudo, os autores ainda associaram a quebra dos agregados ao coeficiente de uniformidade e observaram que a quebra do lastro diminui com o aumento de $C_{u}$. 


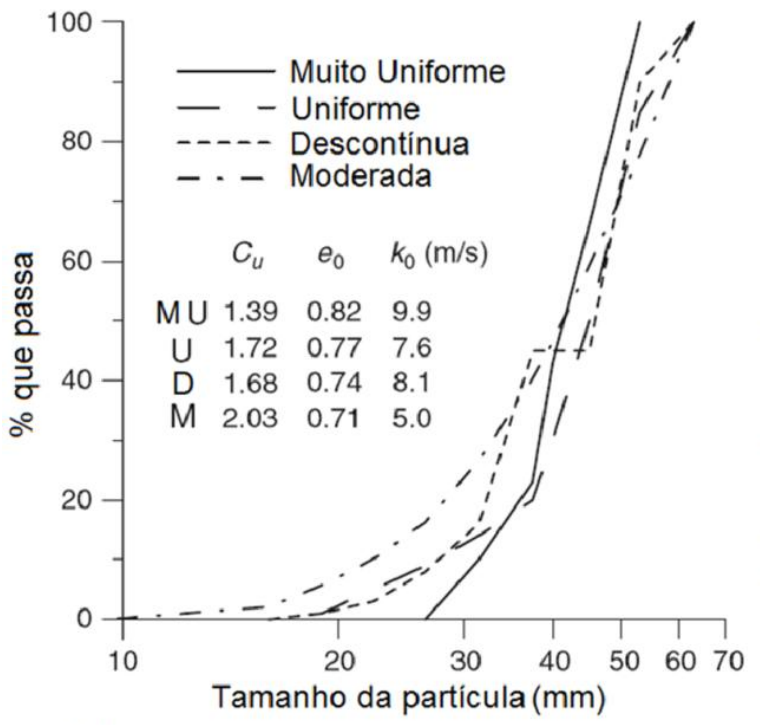

(a)

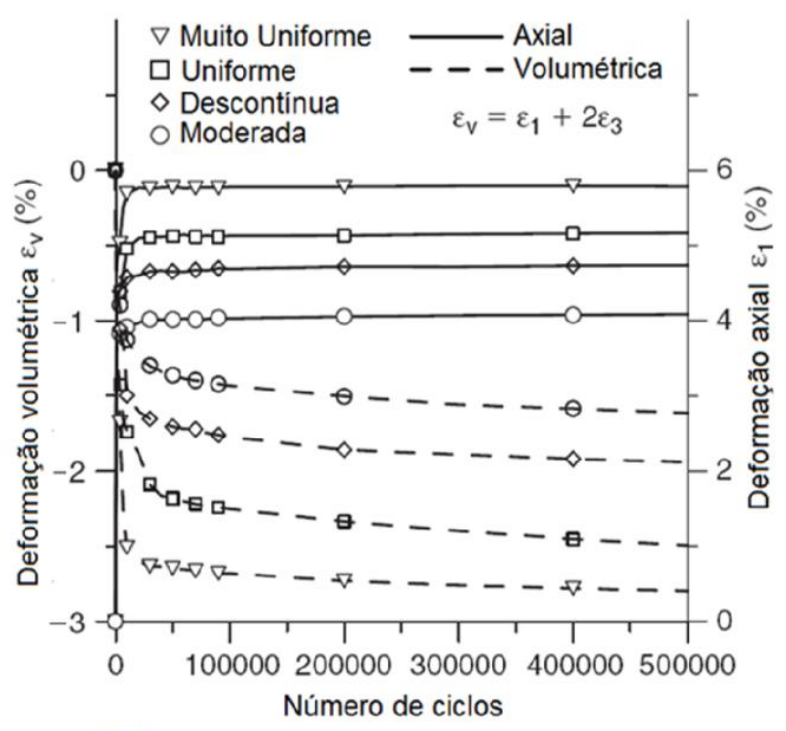

(b)

Figura 25 - (a) Distribuições granulométricas usadas em testes triaxiais cíclicos; (b) deformação axial e volumétrica obtida em testes triaxiais cíclicos (Indraratna et al., 2004)

Na Figura 25(a) nota-se ainda que foi feita a análise da permeabilidade para cada tipo de amostra $\left(k_{0}\right)$, onde observa-se que a curva de graduação moderada possui permeabilidade inicial $50 \%$ menor que uma de distribuição muito uniforme. Os pesquisadores destacam que havendo a ausência de contaminação e a correta manutenção do sistema de drenagem, a permeabilidade de uma graduação melhor distribuída é considerada como suficiente para a drenagem da via permanente, além de apresentarem deformação e resistência mais satisfatórias que no caso das graduações uniformes empregadas atualmente pelas especificações de lastro (Indraratna et al., 2001).

O efeito da contaminação sobre a camada de lastro e, consequentemente, ao comportamento mecânico do sistema ferroviário está relacionado basicamente com três fatores: (i) tipo de material contaminante presente, (ii) quantidade de contaminação e; (iii) teor de água nas camadas geotécnicas (INDRARATNA; SALIM, 2005). Segundo Cocunato (1998), os diferentes tipos de contaminação podem aumentar ou diminuir a rigidez do lastro, impedindo assim, a camada de cumprir plenamente suas funções. A contaminação com materiais finos podem formar bolsões de lama, que aceleram a deterioração da camada, dificulta sensivelmente a drenagem e causa instabilidade da estrutura. Quando os vazios do lastro são preenchidos com materiais menos graúdos ocorre um aumento da rigidez 
e da estabilidade, porém redução da resiliência, ocasionando problemas nas operações de manutenção e danos ao trem.

Ebrahimi et al. (2010) realizaram ensaios triaxiais de grande escala para analisar o efeito dos diferentes tipos de contaminação com diferentes umidades. Em uma primeira análise, feita apenas com um tipo contaminante (material oriundo da quebra do lastro), os pesquisadores sugerem que a contaminação mineral até $20 \%$, por si só, não afeta a deformação plástica quando o material está quase seco (com umidade de até 5\%). Entretanto, quando o teor de umidade se eleva, para valores de 5 a 15\%, as deformações axiais plásticas crescem consideravelmente com o aumento do número de ciclos. Os autores comentam que o aumento da contaminação, pela quebra dos agregados de lastro ou advindas de outras fontes, altera o comportamento do lastro de uma taxa de deformação crescente, porém controlada, para taxas cada vez maiores, até o colapso (teoria do shakedown).

Além da contaminação pela quebra do lastro, Ebrahimi et al. (2010) analisaram, em uma segunda etapa de ensaios, a influência da contaminação por minério de carvão, conforme apresentando na Figura 26 (a) e (b). Para ambos os materiais contaminantes, o aumento da quantidade de água eleva a magnitude da taxa de deformação plástica, mostrando comportamentos similares. Vale ressaltar que a diferença entre a massa específica, do material de lastro $\left(2,6 \mathrm{~g} / \mathrm{cm}^{3}\right)$ e do minério de carvão $\left(1,3 \mathrm{~g} / \mathrm{cm}^{3}\right)$ resultou em diferentes porcentagens de materiais utilizados nos ensaios. A percentagem em peso de contaminação mineral produz a metade do volume da contaminação por pó carvão e, portanto, $20 \%$, em peso, de material de lastro e $10 \%$, de minério foram testados, com isso foi alcançada a mesma relação de contaminação para os ensaios. Os autores utilizaram nos gráficos da Figura 26 (a) e (b), uma representação do limite de correção geométrica, adotada pela Federal Railroad Administration (FRA), para comparar as diferentes taxas de deformação e o processo de manutenção da via, onde se considera que a metade das deformações acontece na camada de lastro. Percebe-se então que, para valores de contaminação e umidade elevados, os processos de alinhamento e manutenção da via são cada vez mais recorrentes. 


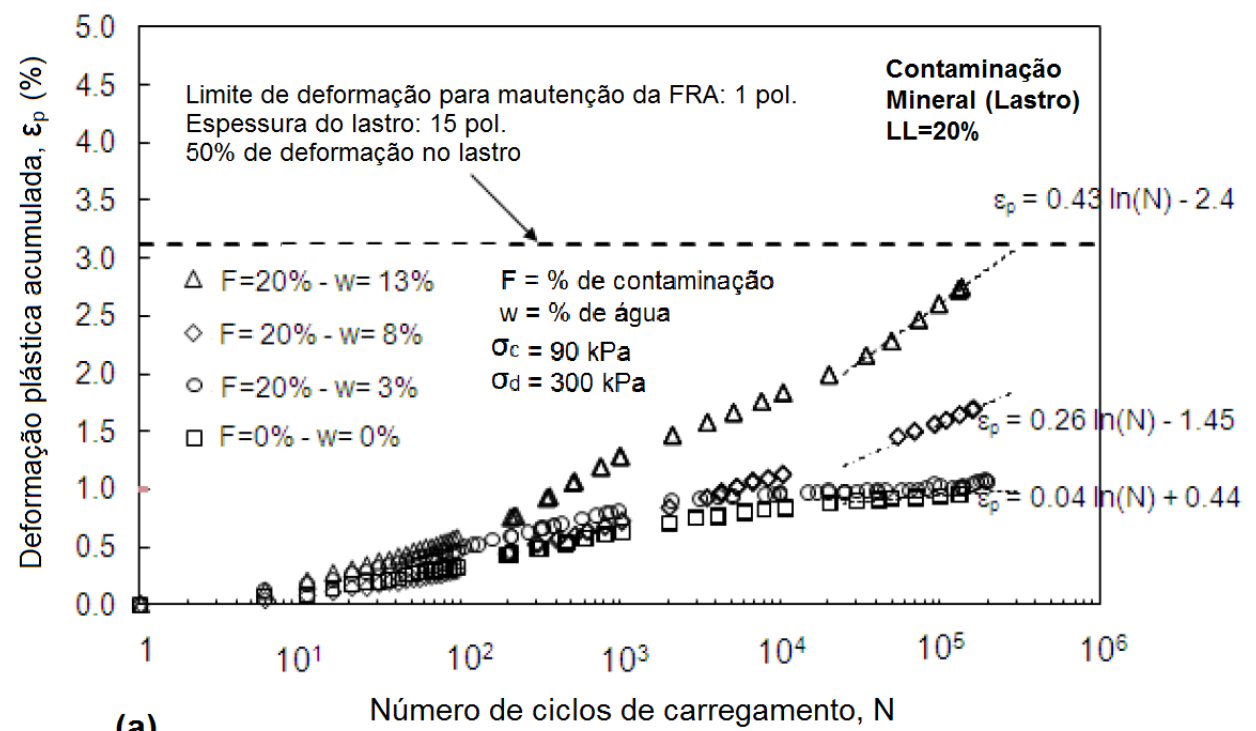

(a)

ou $30 \times \mathrm{N}$ (TBT)

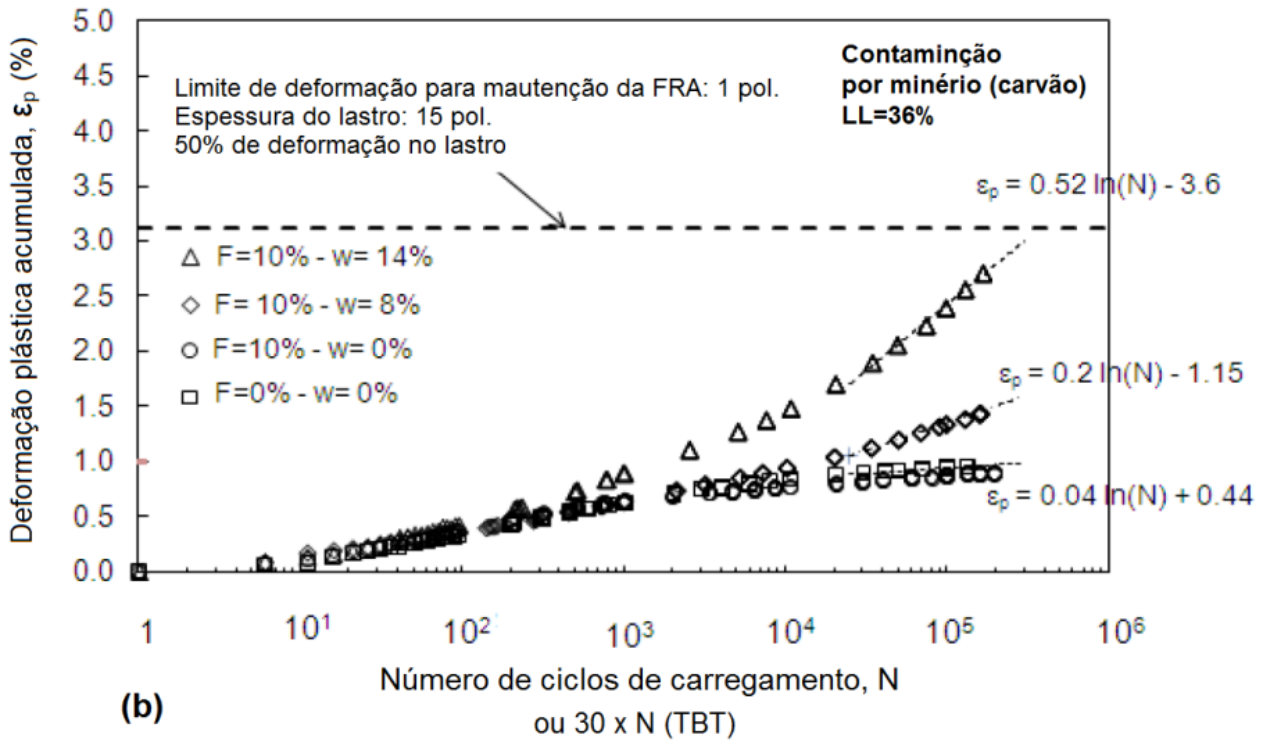

Figura 26 - Comportamento deformacional de lastro contaminado por diferentes materiais em ensaios triaxiais cíclicos (a) Contaminação por material do próprio lastro (quebra) e, (b) Contaminação por minério de carvão (Ebrahimi et al., 2010)

Segundo Hicks e Monismith (1971), a magnitude do módulo de resiliência de materiais granulares é muito dependente do estado de tensões. Bernucci et al. (2007) destacam que o módulo de resiliência deste tipo de material é fortemente influenciado pela tensão de confinamento, onde valores maiores são obtidos quanto maior for a tensão confinante. Estes mesmos autores também relatam que tal efeito acontece com o aumento das tensões desviadoras, porém em menor proporção. Alva-Hurtado (1980) destaca que, dependendo da magnitude da tensão desvio aplicada, como por exemplo, quando se aplica tensões desviadoras próximas à tensão de ruptura do material, elevados valores de módulo de resiliência 
são obtidos, como verificado na Figura 27. Esta mesma imagem apresenta a relação típica para materiais granulares, correlacionando o módulo de resiliência com a somatória das tensões principais aplicadas no ensaio triaxial (invariante de tensões), usando a Equação 3. Outro modo de representar a variação do módulo de resiliência, permitindo a visualização da influência apenas da tensão confinante, é a da Equação 4.

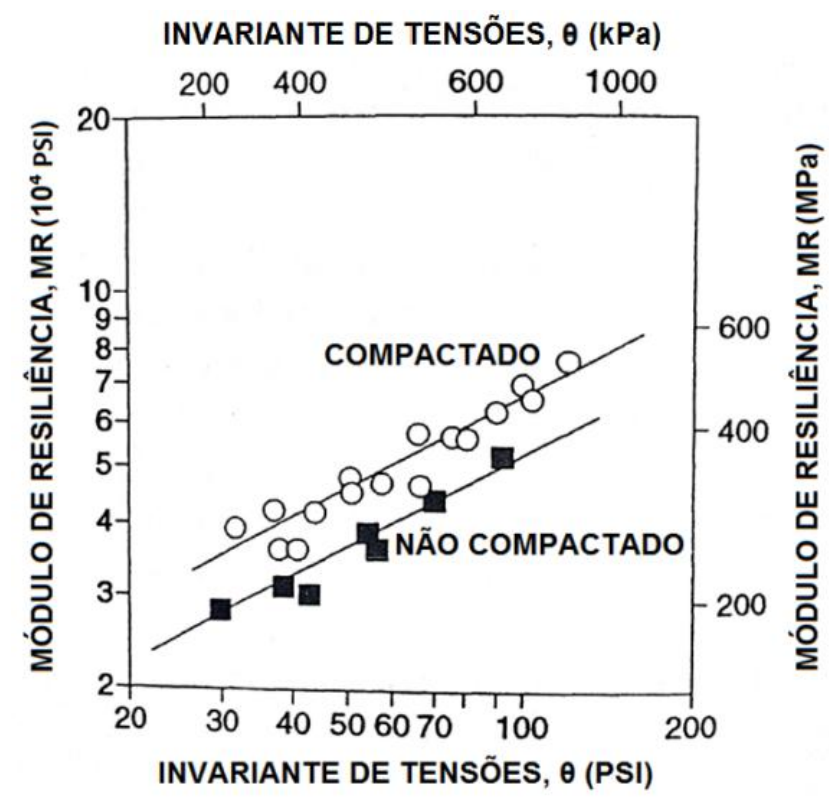

Figura 27 - Relação entre o módulo de resiliência e o estado de tensões (Selig e Waters, 1994)

$$
\begin{gathered}
M R=K_{1}(\theta)^{K_{2}} \\
M R=K_{1}\left(\sigma_{3}\right)^{K_{2}}
\end{gathered}
$$

Onde:

MR = Módulo de Resiliência

$\mathrm{K}_{1}$ e $\mathrm{K}_{2}=$ Constantes determinadas pelos ensaios

$\theta=$ invariante de tensões

$\sigma_{3}=$ Tensão confinante

A compreensão de dois fatores ligados ao carregamento é fundamental para a correta análise do comportamento elasto-plástico do material granular: o nível de carregamento e o número de ciclos, também conhecidos conjuntamente como 
histórico de tensão. Seus efeitos podem ser observados pelo acúmulo de deformação permanente e enrijecimento gradual do material granular, após cada ciclo de carregamento (LEKARP et al., 2000), entretanto, a aplicação de tensões próximas à tensão de ruptura ocasionará o colapso da estrutura em determinado número de ciclos. Desta forma, compreende-se que a escolha da magnitude de tensões, juntamente com o acertado número de ciclos, proporcionará o correto entendimento do comportamento deformacional do material.

lonescu et al. (1998) realizaram uma série de ensaios triaxiais em lastro de basalto em escala real e concluíram que o comportamento de lastro é altamente não-linear, sob carga cíclica (Figura 28). Eles também relataram um aumento rápido nos deslocamentos (semelhante a Indraratna et al. (2004), Figura 25b, e Ebrahimi et al. (2010), Figura 26), durante os primeiros 20 mil ciclos de carga, seguido de uma fase de consolidação até cerca de 100 mil ciclos. Verificou-se que a camada de lastro se estabilizou durante os primeiros 100.000 ciclos de carga, após o qual a deformação aumentou a uma taxa inferior.

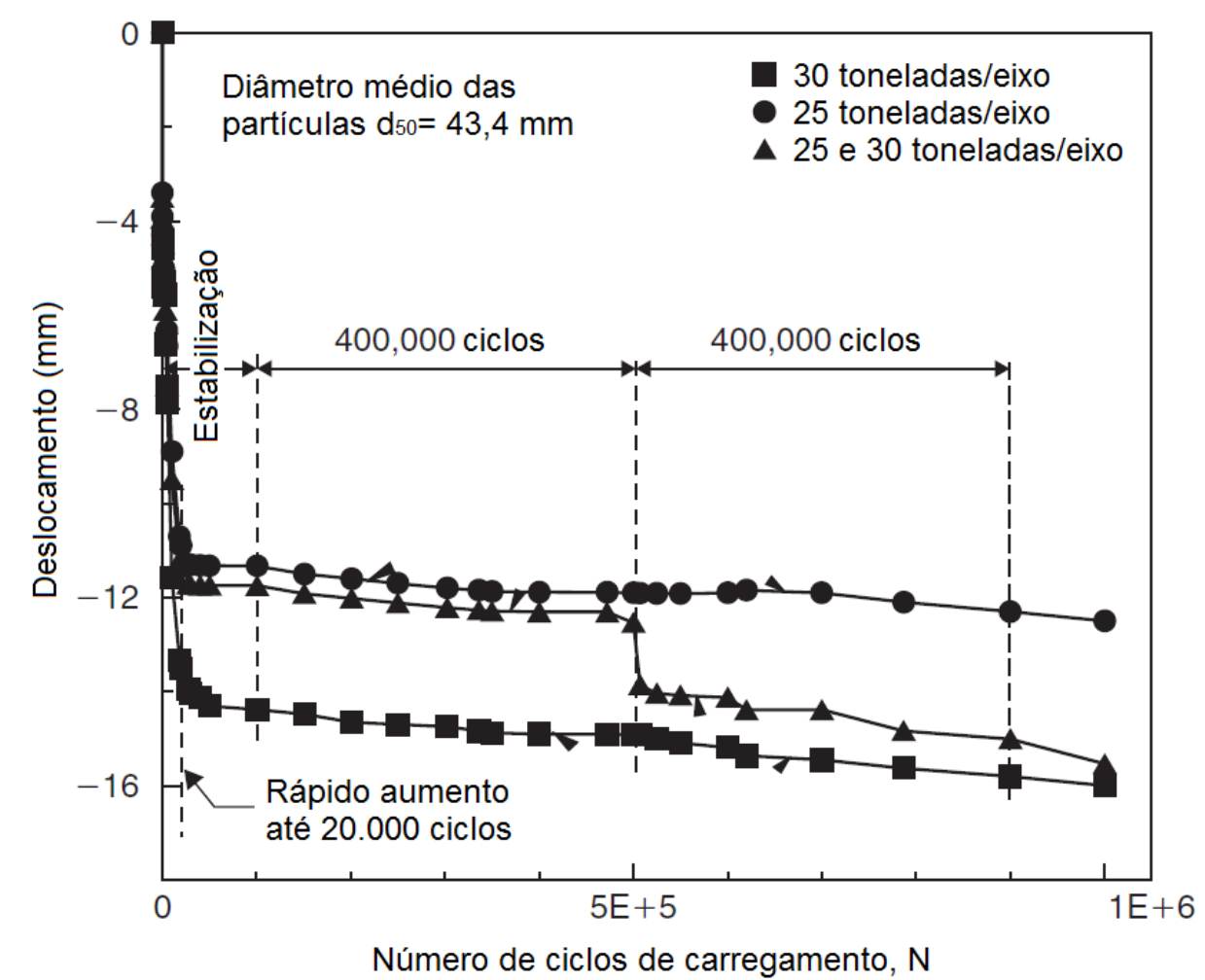

Figura 28 - Ensaios triaxiais, em escala real, realizados em lastro sob carga cíclica (lonescu et al., 1998) 
Outro fato que pode ser percebido pela Figura 26, e já estudado por Stewart (1986), Diyaljee (1987) e Selig e Waters (1994), é que a deformação permanente axial não depende da sequência dos carregamentos, mas sim da tensão máxima aplicada. Este fato fica claro quando ocorre a mudança na aplicação de tensão, passando de valor que representava eixos de 25 toneladas, para nível de tensão de 30 toneladas. Ao final de um milhão de ciclos, os deslocamentos axiais para os dois ensaios, tanto o de tensões combinadas quanto de apenas uma tensão, apresentaram resultados muito próximos.

Stewart (1986) e Selig e Waters (1994) destacam ainda que, se o estado de tensões atual de um material de lastro for menos elevado que algum estado de tensão anterior, as deformações permanentes observadas serão menores do que seriam caso as tensões mais elevadas não tivessem sido aplicadas, pois as deformações terão ocorrido principalmente durante a aplicação dos carregamentos elevados.

\subsubsection{Vida útil e manutenção}

A questão econômica para ferrovias está intimamente ligada com a frequência de intervenções para a manutenção da via, daí importância do conhecimento sobre as condições do lastro como elemento vital para encontrar a faixa ideal de manutenção (ESVELD, 2001). O aumento das cargas transportadas por eixo e da velocidade em que os trens trafegam acarretam em redução da vida útil do lastro, ocasionando uma degradação mais rápida da camada, que está relacionada à geometria e um desgaste maior dos componentes. Como resultado, há necessidade de maior frequência de intervenções para manutenção. No entanto, devido ao desgaste dos agregados pela vida útil e pela socaria, o lastro suporta apenas certo número limite de sessões de manutenção, sendo que o período entre estes processos tornam-se cada vez menores.

A Figura 29 abaixo representa o efeito da contaminação progressiva no processo de manutenção da via, bem como apresenta a contribuição das diferentes camadas da subestrutura (lastro, sublastro e subleito) para a deformação da via. 


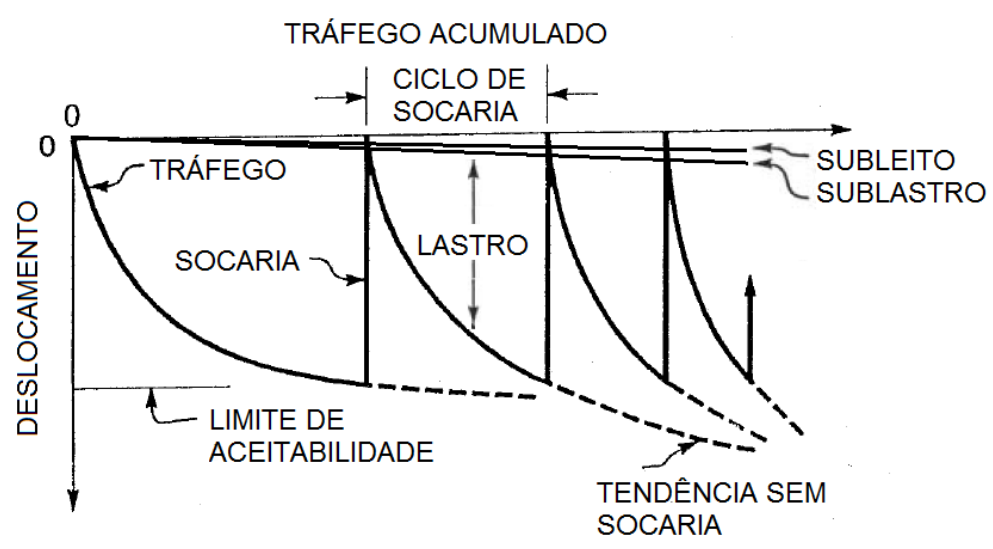

Figura 29 - Efeito da contaminação progressiva no processo de manutenção da via (Selig e Waters, 1994 modificado)

A via convencional deforma vertical e lateralmente sob cargas cíclicas resultantes do tráfego, causando desvio da geometria de projeto. Embora estes desvios sejam aparentemente pequenos, eles causam irregularidades que aumentam a deterioração da via e elevam a carga dinâmica que, por sua vez, prejudica ainda mais o nivelamento e a qualidade do sistema.

Quanto à periodicidade de manutenção, Aursudkij (2007) retrata que, no Reino Unido, os intervalos entre manutenção para a linha principal e secundária acontecem de um a dois anos e de três a quatro anos, respectivamente. No Japão, por exemplo, a linha de alta velocidade de Shinkansen requer processos de manutenção de duas a três vezes por ano, enquanto que a substituição completa do lastro ocorre apenas após cinco anos de operação (IONESCU, 2004).

Segundo Profillidis (2006), a estabilidade e segurança da via depende fundamentalmente de dois parâmetros: de um lado estão os parâmetros geométricos, dos quais a degradação é reversível; e de outro lado, os parâmetros mecânicos que não podem, em geral, ser reparados sem a substituição de componentes (trilhos, fixações, dormentes, etc.).

As variações entre as características geométricas atuais da via e os valores de projeto dependem de certos limites de segurança e aceitabilidade. Qualquer desvio dos padrões estabelecidos classificam essas variações em defeitos, que devem ser reparados através de processo de manutenção e nivelamento do lastro. Três são os tipos mais comuns de defeitos geométricos: defeito vertical, transversal e horizontal. 
O defeito vertical é definido como a diferença entre o valor real do nível da via em relação ao greide de projeto. A determinação do defeito transversal é definida entre o valor teórico e real do nivelamento entre trilhos, por exemplo, em uma seção retilínea, onde a curvatura é zero, onde tal defeito é medido pela diferença entre o trilho externo e interno. Já o defeito horizontal é definido como a alteração planimétrica do perfil da via, e depende fortemente dos efeitos transversais e de características do material rodante (PROFILLIDIS, 2006). Os três tipos de defeitos são apresentados na Figura 30.

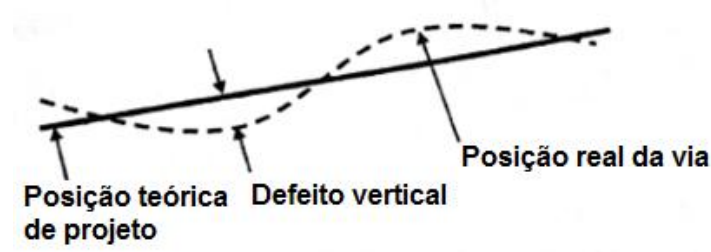

(a)

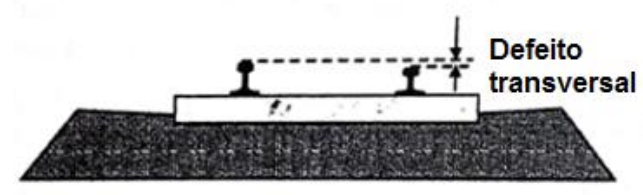

(b)

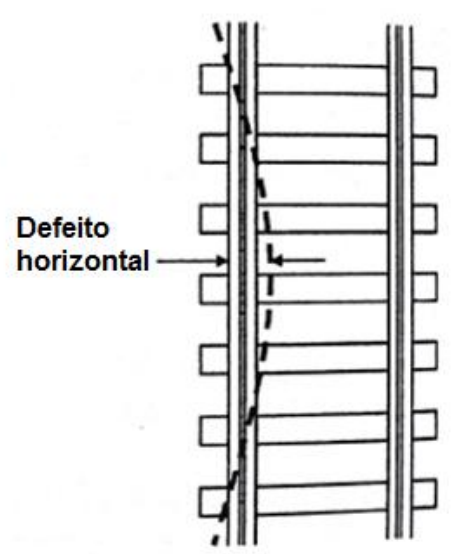

(c)

Figura 30 - (a) Defeito vertical, (b) horizontal e (c) transversal (Profillidis, 2006)

Profillidis (2006) destaca que a classificação das irregularidades está relacionada à velocidade de operação da via, e que a decisão sobre o processo de manutenção está subdividida em três níveis:

- Limite de intervenção: Valores os quais alguma intervenção de manutenção deve ser realizada para reaver a estabilidade do sistema, caso contrário os níveis de segurança caem e a confiabilidade no sistema diminui (Tabela 3);

- Limite emergência: Se os defeitos ultrapassarem este limite uma imediata redução da velocidade de operação deve ser imposta e a qualidade da via pode estar definitivamente comprometida (Tabela 4).

- Limite de aceitação: São valores que após os ciclos de manutenção as irregularidades devem se enquadrar, caso contrário dificilmente ocorrerá o posicionamento ideal da via novamente (Tabela 5). 
Tabela 3 - Valores limites de defeitos para intervenção e manutenção de ferrovias de alguns países ${ }^{5}$ (Profillidis, 2006).

\begin{tabular}{|c|c|c|c|c|c|c|c|c|c|c|}
\hline $\begin{array}{c}\text { Velocidade } \\
\text { da via }\end{array}$ & \multicolumn{4}{|c|}{$\begin{array}{c}\text { Defeito vertical }(\mathrm{mm}) \\
\text { transversal } \\
(\mathrm{mm})\end{array}$} & \multicolumn{4}{|c|}{$\begin{array}{c}\text { Defeito horizontal } \\
(\mathrm{mm})\end{array}$} \\
\hline$(\mathrm{km} / \mathrm{h})$ & DB & SNCF & NS & UIC & DB & NS & DB & SNFC & NS & UIC \\
\hline 140 a 160 & 9 & 12 & 10 & 10 & 6 & 7 & 9 & 9 & 5 & 8 \\
\hline 120 a 140 & 11 & 13 & 11 & 10 & 7 & 7 & 11 & 10 & 6 & 8 \\
\hline 100 a 120 & 11 & 15 & 11 & 12 & 7 & 7 & 11 & 12 & 6 & 10 \\
\hline 80 a 100 & 11 & 17 & 12 & 12 & 7 & 8 & 11 & 14 & 8 & 10 \\
\hline 60 a 80 & 14 & 19 & 12 & 16 & 11 & 8 & 14 & 17 & 8 & 14 \\
\hline$<60$ & 14 & 21 & 12 & 16 & 11 & 8 & 14 & 20 & 8 & 14 \\
\hline
\end{tabular}

Tabela 4 - Valores de emergência para defeitos de acordo com a velocidade máxima permitida (Profillidis, 2006).

\begin{tabular}{|c|c|c|}
\hline $\begin{array}{c}\text { Velocidade } \\
\text { máxima da } \\
\text { via }(\mathrm{km} / \mathrm{h})\end{array}$ & $\begin{array}{c}\text { Defeito } \\
\text { vertical } \\
(\mathrm{mm})\end{array}$ & $\begin{array}{c}\text { Defeito } \\
\text { horizontal } \\
(\mathrm{mm})\end{array}$ \\
\hline 140 & $\geq 18$ & $\geq 15$ \\
\hline 120 & $\geq 20$ & $\geq 17$ \\
\hline 100 & $\geq 23$ & $\geq 19$ \\
\hline 80 & $\geq 25$ & $\geq 22$ \\
\hline 60 & $\geq 27$ & $\geq 25$ \\
\hline 40 & $\geq 30$ & $\geq 28$ \\
\hline
\end{tabular}

Tabela 5 - Valores aceitáveis para defeitos, após execução de manutenção (Profillidis, 2006).

\begin{tabular}{|c|c|c|c|c|c|}
\hline Velocidade da via $(\mathrm{km} / \mathrm{h})$ & $>250$ & 200 a 250 & 120 a 200 & $>80$ & $<80$ \\
\hline Defeito vertical $(\mathrm{mm})$ & 2 & 3 & 3 & 4 & 5 \\
\hline Defeito horizontal $(\mathrm{mm})$ & 2 & 3 & 3 & 4 & 5 \\
\hline
\end{tabular}

Segundo Indraratna et al. (2011), existem dois métodos de manutenção geometria da via: socaria e stoneblowing. Socaria é o método tradicional e é frequentemente utilizado em todo o mundo para corrigir a geometria da via. Consiste em elevar os componentes da subestrutura, até o nível de projeto, e pressionar o lastro lateralmente por baixo do dormente, até minimizar os espaços vazios gerados pela operação de elevação. Na técnica do stoneblowing, a máquina ergue o dormente e injeta, com auxílio de ar comprimido, uma quantidade predeterminada de pequenos fragmentos de rocha de tamanho único no vazio criado, a fim de propiciar uma base estável para cada dormente.

5 DB: Ferrovias alemãs; SNFC: Ferrovias francesas; NS: Ferrovias holandesas; UIC: International Union of Railways 
Em um estudo, Wright (1983) mostrou que tanto os processos de socaria quanto stoneblowing deterioram os agregados do lastro, durante a inserção do equipamento para dentro da camada. No entanto, o stoneblowing produziu até oito vezes menos agregados finos do que a socaria. No mesmo estudo, relata-se que após o stoneblowing a qualidade da pista não só melhorou, mas também foi mantida durante um período mais longo de tempo. 


\section{PROGRAMA DE ENSAIOS}

O programa experimental está dividido em duas etapas: (i) caracterização física completa dos materiais de acordo com a ABNT 5564 (2011) e AREMA (2009); (ii) e ensaios triaxiais de grande e pequena escala, com o intuito de analisar o comportamento mecânico dos materiais para lastro ferroviários.

\subsection{MATERIAIS ANALISADOS}

Para a realização dos ensaios de caracterização física e de comportamento mecânico, utilizou-se basicamente de materiais oriundos do pátio de armazenamento de agregados da Vale S.A., em Cariacica (ES), que, segundo informações fornecidas pela empresa, é abastecido semanalmente com aproximadamente $5.000 \mathrm{~m}^{3}$ de agregados da Pedreira Brasitália (também em Cariacica). Vale ressaltar que, para a amostragem em pilha no pátio, utilizou-se do anexo G da norma ABNT 5564 (2011), que especifica os detalhes para este tipo de coleta, Figura 31.
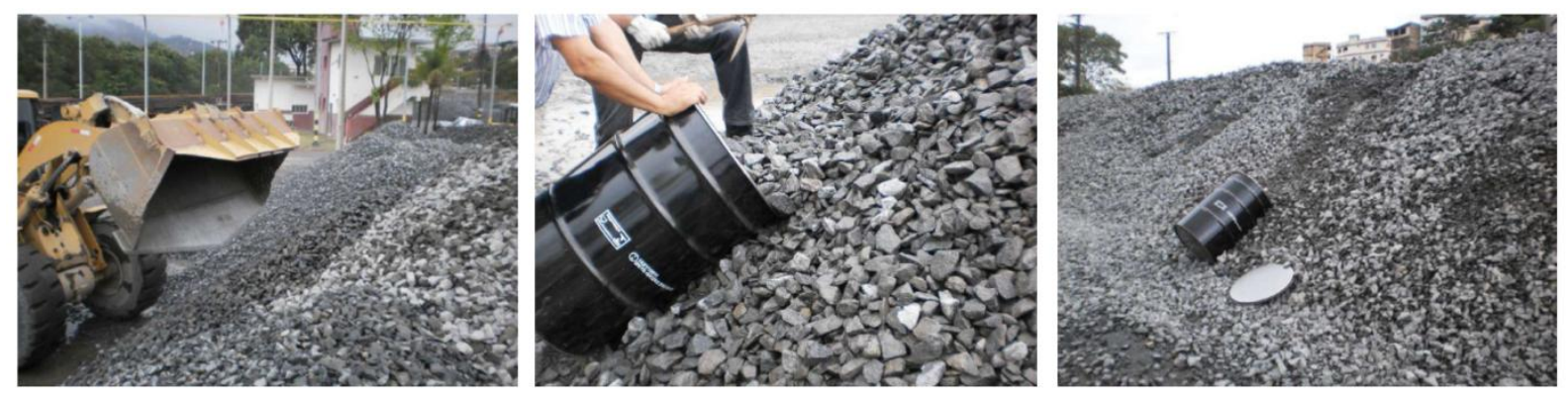

Figura 31 - Coleta realizada no pátio de estocagem da Vale S.A., em Cariacica (ES)

Para a realização de ensaios mecânicos de forma decalada nesta pesquisa, foi necessário fazer uma nova amostragem especial, junto à Pedreira Brasitália, fornecedora de lastro para a Estrada de Ferro Vitória Minas (EFVM), para a obtenção de agregados de menores dimensões, pois os materiais no pátio de estocagem continham dimensões entre $12,5 \mathrm{~mm}$ e $63 \mathrm{~mm}$ e não eram suficientes para compor a granulometria decalada comparativa, Figura 32. 

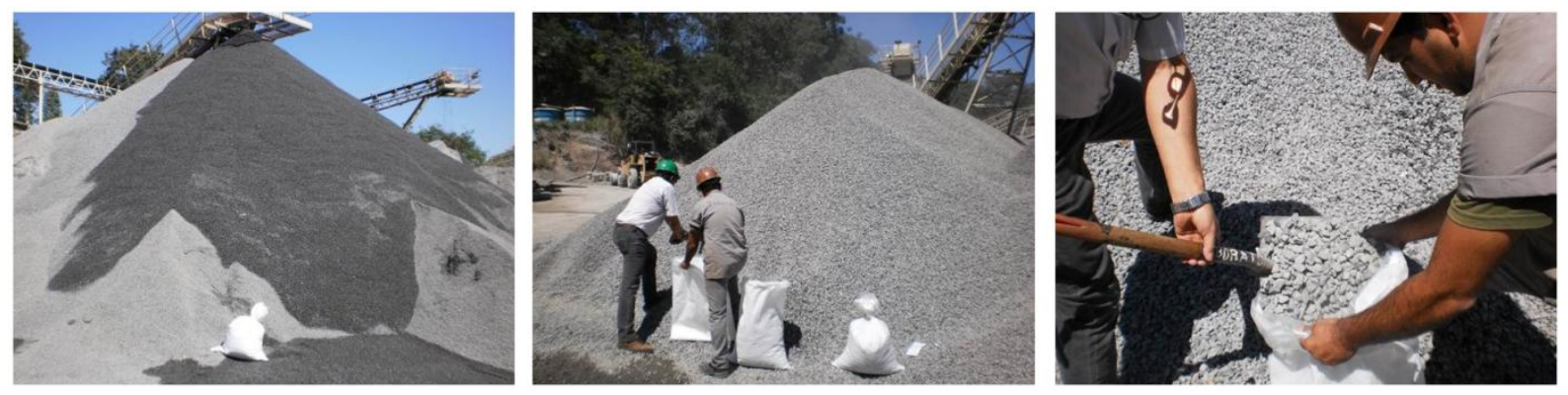

Figura 32 - Detalhe da coleta realizada na pedreira Brasitália

\subsection{CARACTERIZAÇÃO FÍSICA}

Esta etapa visou verificar se os agregados de lastro desta pesquisa atendiam às especificações brasileira e norte americana, adotadas pela Vale S.A. Os resultados, por ensaio, juntamente com uma descrição sucinta do teste estarão apresentados neste capítulo, subitem 3.4.1. Os ensaios de caracterização estão programados em função dos limites estabelecidos pelas duas especificações supracitadas, para lastros ferroviários, sintetizados na Tabela 1 (subitem 2.2.1). Tanto a normatização brasileira quanto o manual americano elencam em qual anexo ou norma cada ensaio deve se basear.

\subsection{ANÁLISE DAS PROPRIEDADES MECÂNICAS}

\subsubsection{Ensaios Triaxiais}

Os ensaios mecânicos foram divididos em dois grupos, por tamanho do corpo de prova: (i) grande escala ou verdadeira grandeza, com 400×800 mm; e (ii) de pequena escala, com $150 \times 300 \mathrm{~mm}$. Desta forma, esperava-se constatar a viabilidade de execução de ensaios em grande escala, realizar um estudo comparativo entre corpos de prova de diferentes tamanhos para investigar a técnica de decalagem por graduação paralela, e estudar a influência de mudanças de carregamento combinadas às características do material no comportamento mecânico do lastro. A distribuição dos ensaios, de acordo com a proposta de análise, está exposta na Figura 33 a seguir. Na Tabela 6 estão descritos todos os detalhes de cada condição. 
Tabela 6 - Detalhes de cada condição avaliada

\begin{tabular}{|c|c|c|c|c|c|c|c|c|}
\hline Amostra & $\begin{array}{c}\text { Dimensão } \\
(\mathrm{mm})\end{array}$ & $\begin{array}{l}\text { Graduação } \\
\text { (AREMA) }\end{array}$ & Material & \begin{tabular}{|l|} 
Tipo de \\
ensaio
\end{tabular} & $\begin{array}{l}\text { № de } \\
\text { ciclos }\end{array}$ & Tipo de ciclo & $\begin{array}{c}\sigma_{3} \\
(\mathrm{kPa})\end{array}$ & $\sigma_{1 / \sigma_{3}}$ \\
\hline GE I & $400 \times 800$ & 24 & limpo & $\mathrm{DP}$ & 290.000 & Indraratna* & 65 & $3 ; 4 ; 5 ; 6$ \\
\hline GE ॥ & $400 \times 800$ & 3 & limpo & DP & 290.000 & Indraratna* & 65 & $3 ; 4 ; 5 ; 6$ \\
\hline GE III & $400 \times 800$ & 24 & contaminado & $\mathrm{DP}$ & 290.000 & Indraratna* & 65 & $3 ; 4 ; 5 ; 6$ \\
\hline PE I & $150 \times 300$ & 24 & limpo & DP & 290.000 & Indraratna* & 65 & $3 ; 4 ; 5 ; 6$ \\
\hline PE II & $150 \times 300$ & 3 & limpo & DP & 290.000 & Indraratna* & 65 & $3 ; 4 ; 5 ; 6$ \\
\hline PE III & $150 \times 300$ & 24 & contaminado & $\mathrm{DP}$ & 290.000 & Indraratna* & 65 & $3 ; 4 ; 5 ; 6$ \\
\hline PE IV & $150 \times 300$ & 24 & $\begin{array}{l}\text { contaminado } \\
\text { úmido }\end{array}$ & DP & 290.000 & Indraratna* & 65 & $3 ; 4 ; 5 ; 6$ \\
\hline PE V & $150 \times 300$ & 24 & limpo & $\mathrm{DP}$ & 250.000 & Medido & 65 & 5 \\
\hline PE VI & $150 \times 300$ & 24 & limpo & DP & 250.000 & Indraratna* & 65 & 5 \\
\hline PE VII & $150 \times 300$ & 3 & limpo & DP & 250.000 & Medido & 65 & 5 \\
\hline PE VIII & $150 \times 300$ & 3 & limpo & DP & 250.000 & Indraratna* & 65 & 5 \\
\hline PE IX & $150 \times 300$ & 24 & limpo & DP & 160.000 & Indraratna* & $65 ; 50$ & $3 ; 4 ; 5 ; 6 ; 7$ \\
\hline PEX & $150 \times 300$ & 3 & limpo & DP & 160.000 & Indraratna* & $65 ; 50$ & $3 ; 4 ; 5 ; 6 ; 7$ \\
\hline PEXI & $150 \times 300$ & 24 & limpo & MR & - & - & variável & variável \\
\hline
\end{tabular}

* Indraratna et al. (2010b)

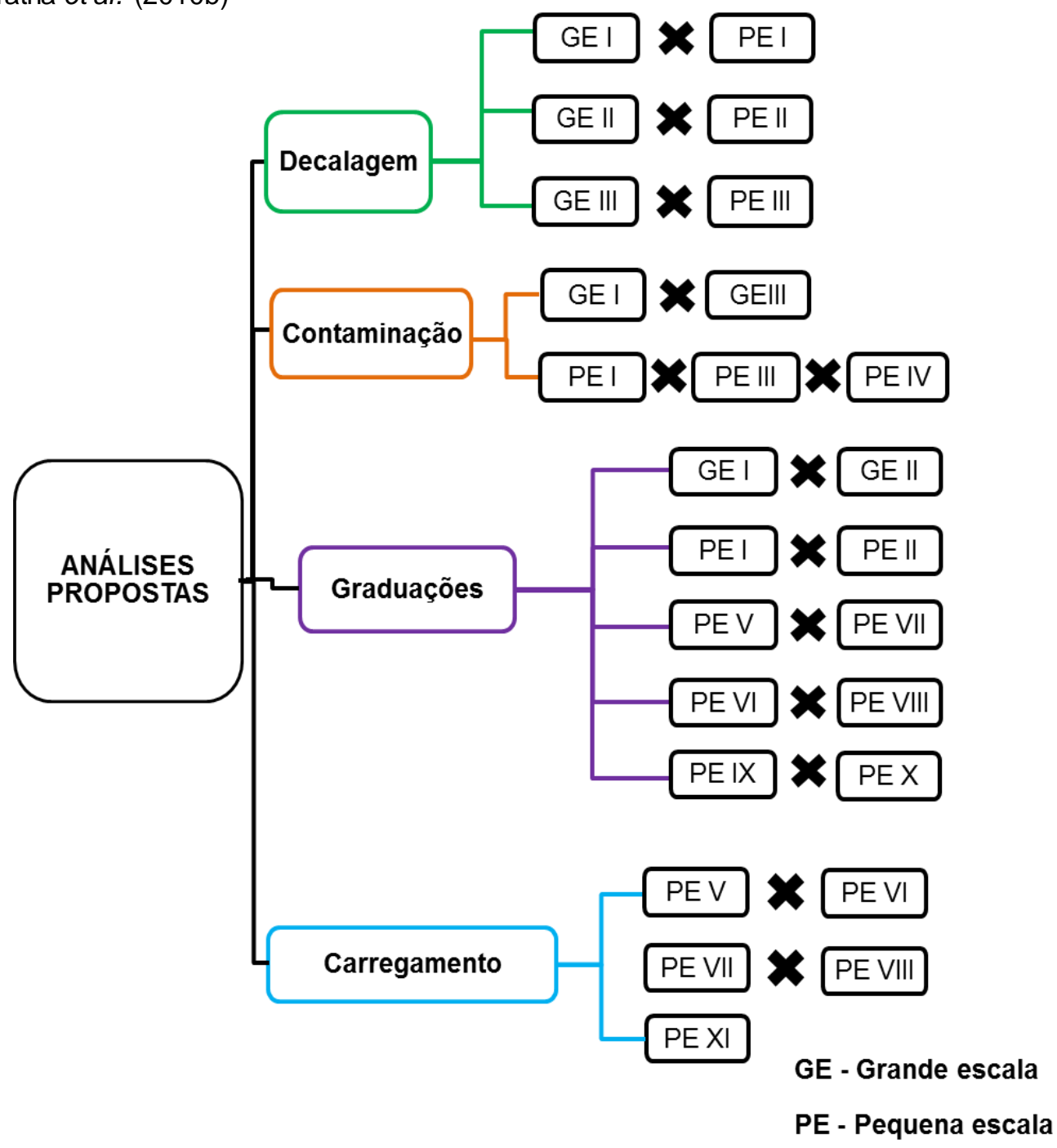

Figura 33 - Distribuição dos ensaios, por análise proposta 
Foram realizados ensaios de deformação permanente e de módulo de resiliência, embora não exista normatização específica para estes ensaios. Os procedimentos adotados para cada análise estarão descritos antes da apresentação dos resultados, pois desta forma, espera-se proporcionar melhor compreensão dos dados.

\subsubsection{Triaxial de verdadeira grandeza - LTP}

Um equipamento triaxial, capaz de ensaiar agregados de grande dimensão, foi desenvolvido no LTP, com capacidade para testar corpos de prova de $400 \mathrm{~mm}$ de diâmetro e $800 \mathrm{~mm}$ de altura, tendo sido concebido para realizar testes cíclicos em diferentes pressões confinantes, frequências, formas de pulso e condições de drenagem. O corpo de prova com tais dimensões proporciona ensaios em agregados com diâmetro máximo de até $63 \mathrm{~mm}$ com uma relação de $\mathrm{D} / d_{\text {máx }}$ de 6,35 sendo esta proporção adequada e citada por diversos autores (como descrito no subitem 2.2.2.3).

Alguns detalhes importantes também fizeram parte da concepção do equipamento, como: (i) confecção de um molde em aço (pesando cerca de $235 \mathrm{~kg}$ ), composto de duas bases (superior e inferior) e quatro subdivisões laterais, conferindo robustez necessária ao conjunto e facilidade de desmoldagem. Ressalta-se que tanto a base inferior quanto à superior possuem orifícios que permitem a aplicação do confinamento à vácuo, diferentemente de triaxiais tradicionais em que a pressão confinante é fornecida por um fluido contido no interior da câmara triaxial. Este sistema de vácuo foi escolhido devido ao tamanho do corpo de prova, onde a adoção de uma abordagem semelhante a uma célula triaxial tradicional com fluido teria que ser demasiadamente robusta para os padrões do laboratório.

O sistema de vácuo é capaz de aplicar tensões confinantes de até $80 \mathrm{kPa}$, sendo este valor suficiente para o estudo de agregados empregados em ferrovias (SEVI, 2008); (ii) confecção de uma grua de transporte com sistema de içamento hidráulico para movimentação de amostras de grandes dimensões no laboratório, com capacidade para comportar um corpo de prova (molde + material) de até $600 \mathrm{~kg}$; e (iii) aquisição de um aparelho elétrico de vibração, próprio para as dimensões do 
equipamento, para compactar o material no molde, em camadas, por vibração. Os detalhes de toda a aparelhagem podem ser vistos na Figura 34.
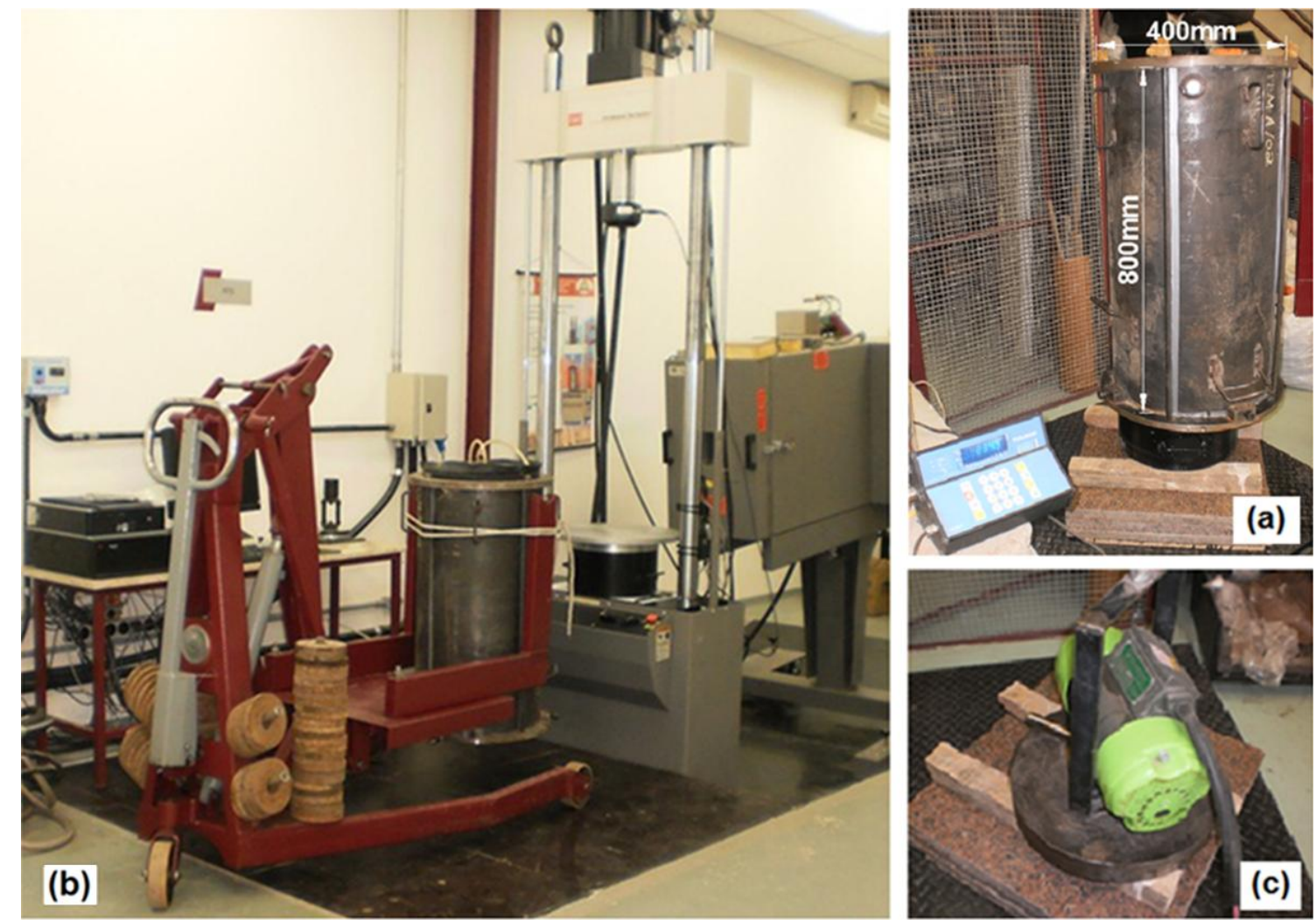

Figura 34 - Aparato triaxial de verdadeira grandeza no LTP (a) pesagem do molde, (b) grua de transporte e bancada de ensaio, e (c) vibrador elétrico

O carregamento é imposto pelo atuador Material Test System (MTS 810), que é capaz de aplicar cargas de até $100 \mathrm{kN}$. Nos testes iniciais para o desenvolvimento deste equipamento, foi atingida uma frequência de ensaio de $9 \mathrm{~Hz}$ (que corresponde à velocidade de um trem de carga típico de 60 a $70 \mathrm{~km} / \mathrm{h}$ ), sem que houvesse nenhum desequilíbrio hidráulico (observou-se que, em frequências superiores, havia perda de harmonia entre as tensões solicitadas e as aplicadas, por conta da instabilidade hidráulica que um corpo de prova de grandes dimensões ocasiona quando levado a tensões elevadas). De qualquer forma, foi atingida a frequência típica de carregamento para um trem de carga, que é da ordem de 8 a $10 \mathrm{~Hz}$ (segundo Aursudkij, 2007), tornando o ensaio que foi realizado como sendo representativo da situação para trens de carga.

Outro ponto fundamental para a realização do ensaio em grande escala é a colagem da membrana de látex que envolve o material. Pelo fato de não existir a 
comercialização de membranas com tamanhos personalizadas com $400 \mathrm{~mm} \times 800$ $\mathrm{mm}$ e $2 \mathrm{~mm}$ de espessura, houve a necessidade de confeccionar uma membrana cilíndrica para o teste, a partir de um rolo com dimensões superiores à dimensão requerida, para que não houvesse mais de um ponto de emenda. No local de colagem, que corresponde a uma geratriz do corpo de prova, foi deixada uma faixa de $100 \mathrm{~mm}$ em cada extremidade, formando uma área de sobreposição para a emenda. Estas áreas de emenda foram lixadas e limpas antes da aplicação da cola, para permitir melhor aderência (Figura 35a). A secagem foi realizada com a membrana sendo mantida em um molde plástico, com a mesma largura do corpo de prova, até a aderência entre as partes (Figura 35b).
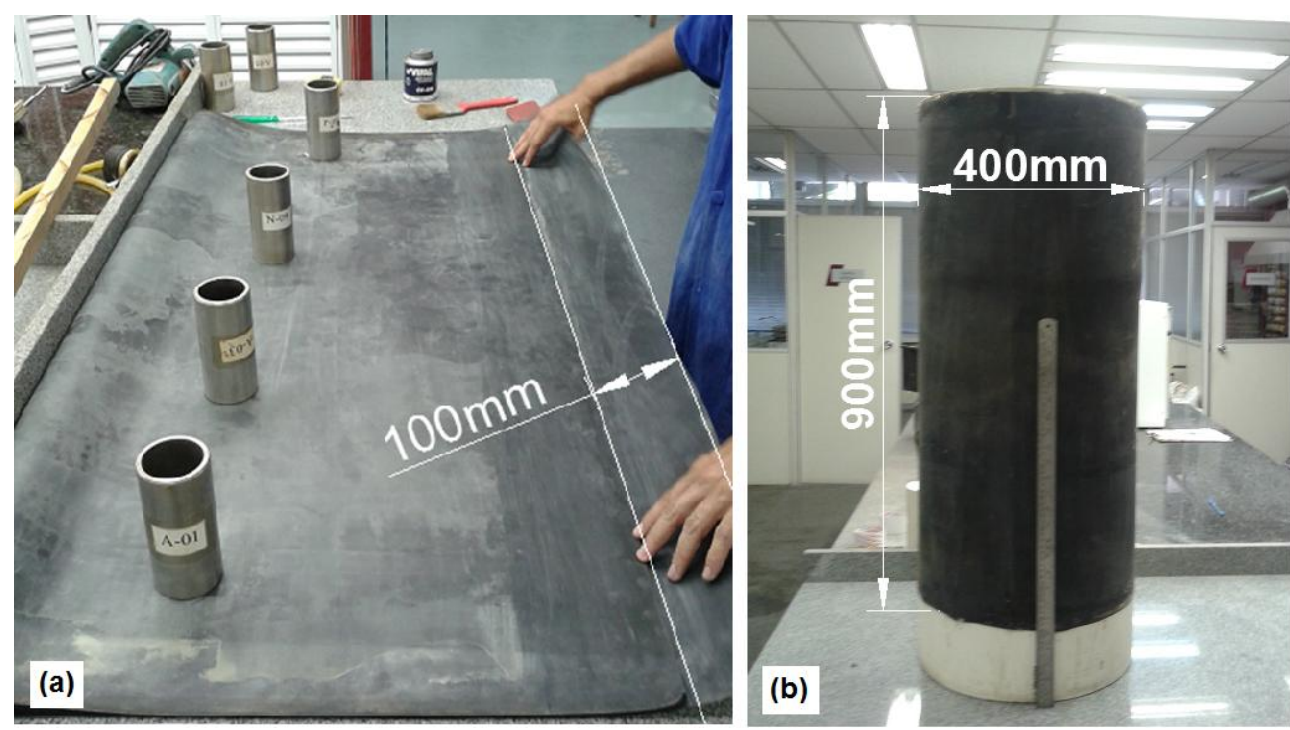

Figura 35 - (a) Detalhe da colagem da membrana e (b) Detalhe da membrana mantida no molde plástico para a secagem

\subsubsection{Triaxial em escala reduzida}

O equipamento triaxial com $150 \mathrm{~mm}$ de diâmetro e $300 \mathrm{~mm}$ de altura com molde tripartido que é usualmente utilizado para realização dos ensaios mecânicos dos materiais estudados pelo Laboratório de Pavimentação, foi utilizado para os ensaios em escala reduzida (Figura 36). Conforme citado anteriormente, foi empregada a técnica de decalagem granulométrica por graduação paralela, a fim de tentar representar, em amostras de menor dimensão, o comportamento de agregados maiores. A translação da curva granulométrica visa respeitar os limites sugeridos pela AASTHO T292 - 91, onde se procura manter o paralelismo da granulometria, 
tanto pela porcentagem acumulada quanto pela porcentagem individual de cada fração.
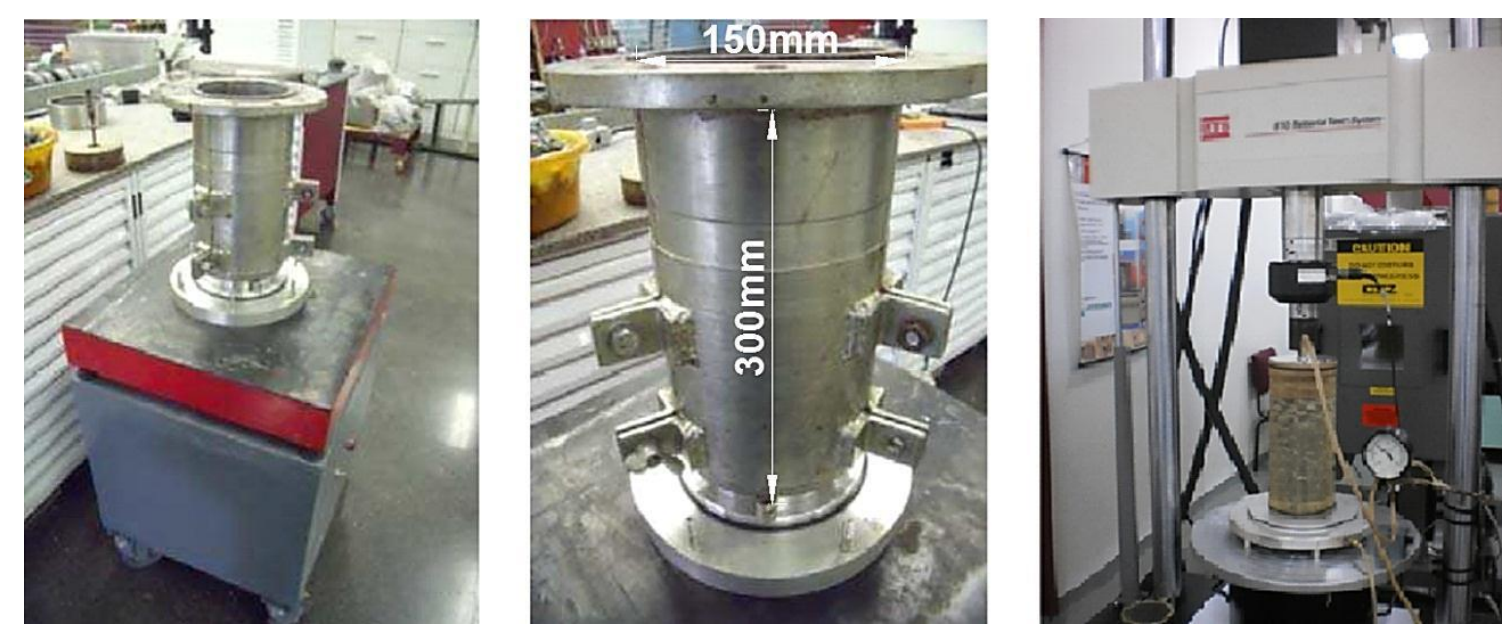

Figura 36 - Detalhes do triaxial 150x300 mm

Assim como para as amostras de maior dimensão, a prensa atuadora utilizada será a MTS 810. Nestas amostras, o método de aplicação de tensão confinante também foi por vácuo. Os ensaios decalados seguiram os mesmos valores de tensão axial, tensão confinante e frequência daqueles em escala real, permitindo a comparação entre os resultados.

\section{Ciclo de carregamento}

O cálculo da tensão a ser empregada nos ensaios seguiu os padrões citados por Talbot (1920) e Selig e Waters (1994), que se fundamentam em soluções de uma viga com apoio contínuo e elástico em análises de Winkler (Equação 1). Os parâmetros adotados para o cálculo são apresentados na Tabela 7, cujos valores de referência foram obtidos na literatura (ALVES; SINAY, 2005; STEWART, 1986; ESVELD, 2001). 
Tabela 7- Valores de referência adotados para o cálculo das tensões atuantes

\begin{tabular}{|c|c|}
\hline Parâmetro & $\begin{array}{c}\text { Valor de } \\
\text { Referência }\end{array}$ \\
\hline Espaçamento entre dormentes & $0,6 \mathrm{~m}$ \\
\hline Módulo de via $(\mathbf{u})$ & $40 \mathrm{MPa}$ \\
\hline Carga por eixo $\left(\mathbf{Q}_{\mathbf{0}}\right)$ & Variável \\
\hline Fator de incremento dinâmico (FID) & 1,0 \\
\hline Momento de inércia dos trilhos (I) & $2,04 \times 10^{-5} \mathrm{~m}^{4}$ \\
\hline Comprimento do dormente & $2,0 \mathrm{~m}$ \\
\hline Largura do dormente & $0,24 \mathrm{~m}$ \\
\hline
\end{tabular}

No cálculo, foram consideradas diferentes cargas por eixo, representando ferrovias que transportam 15, 22, 27,5, 32,5 e 40 t/eixo. Assim, foram obtidas as tensões abaixo dos dormentes (no eixo do trilho), correspondentes à tensão principal maior $\left(\sigma_{1}\right)$ que atua na direção vertical da via permanente (sendo que se a esta for subtraída a tensão confinante tem-se a tensão-desvio $\left(\sigma_{d}\right)$ com valores de 195, 260, 325,390 e $455 \mathrm{kPa}$ para cada tipo de ferrovia supracitada, respectivamente). A combinação a ser escolhida para cada ensaio será descrita nos itens referentes aos resultados de cada análise.

A forma de carga cíclica típica a ser aplicada no ensaio triaxial é apresentada na Figura 37, segundo o modelo usado por Indraratna et al. (2010b). A tensão axial mínima cíclica $\left(q_{\text {mín }}\right)$ foi mantida em $45 \mathrm{kPa}$, a qual representa o estado da via sem a passagem do trem, consistindo assim no peso da superestrutura.

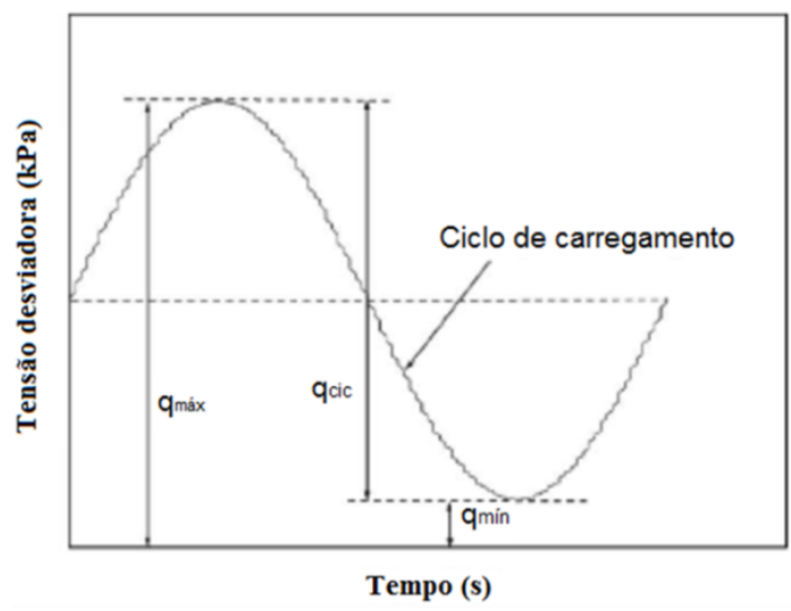

Figura 37 - Ciclo de carregamento típico utilizado nos ensaios triaxiais (Indraratna et al., 2010b) 
Outro modelo de carregamento com base em medidas de campo realizadas pelos técnicos do Laboratório Tecnologia de Pavimentação na Estrada de Ferro Vitória Minas, foi testado em algumas amostras, com o objetivo de entender a influência do carregamento no comportamento elasto-plástico do material. Este levantamento de deslocamentos verticais foi realizado através de equipamento LVDT (linear variable differential transformer) em um ponto da via permanente, com o intuito de entender os efeitos dinâmicos causados pela passagem do trem (Figura 38).

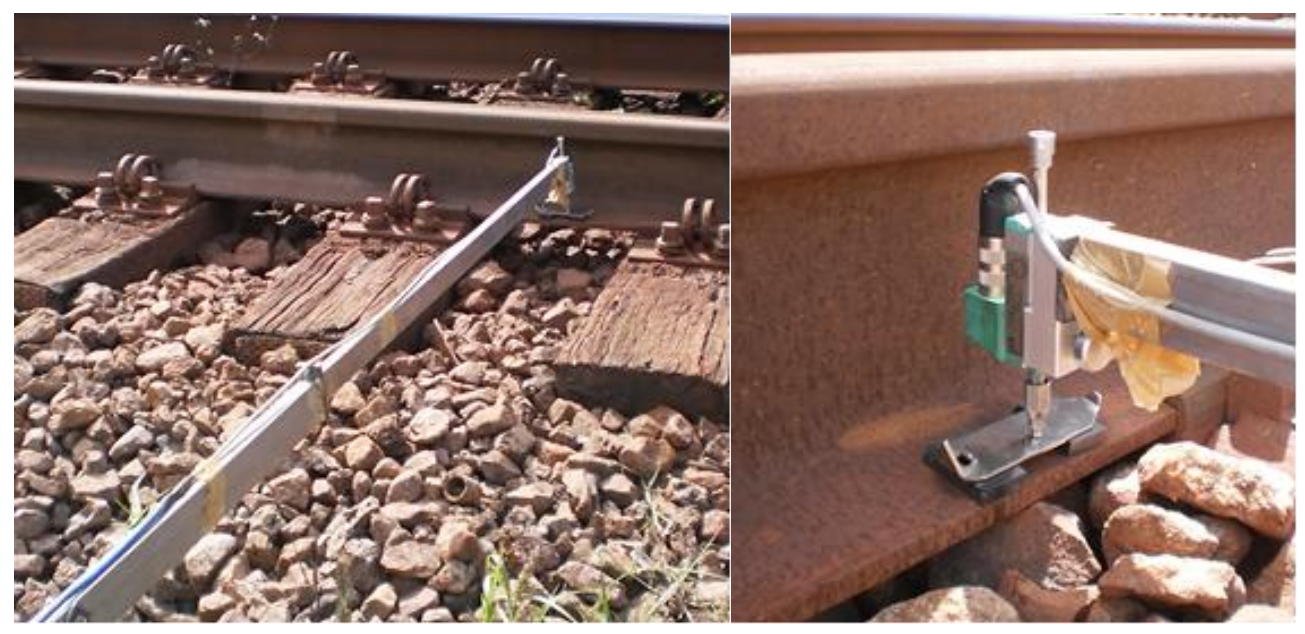

(a)

(b)

Figura 38 - (a) Braço de sustentação do equipamento; e (b) detalhe do posicionamento LVDT

O equipamento baseia-se na leitura, de deslocamento vertical com precisão da ordem de 0,01 $\mathrm{mm}$, cujo registro é feito através de um sistema de coleta por computador. Quanto à frequência de leitura, o aparelho capta os dados em $100 \mathrm{~Hz}$, com possibilidade de aumento do registro de leitura. A seguir, têm-se os detalhes do sinal captado, juntamente com o tratamento deste pela Transformada Discreta de Fourier (Figura 39), além do ciclo de carregamento obtido com base nestas medidas. 


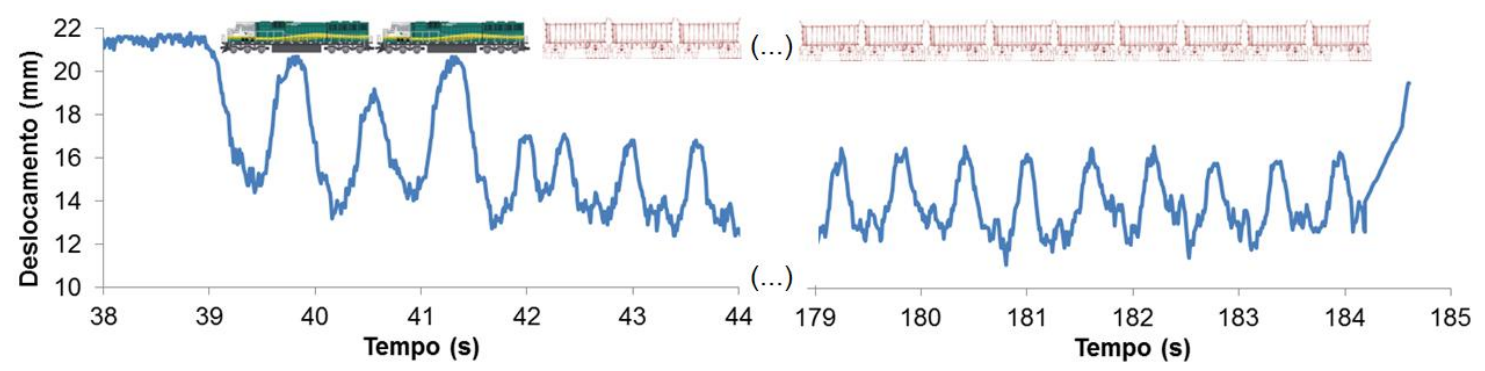

(a)

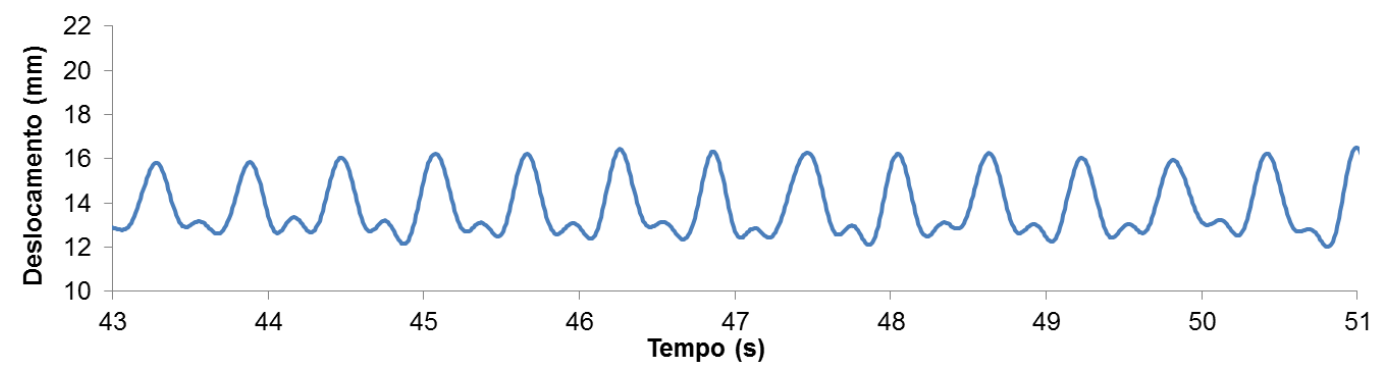

(b)

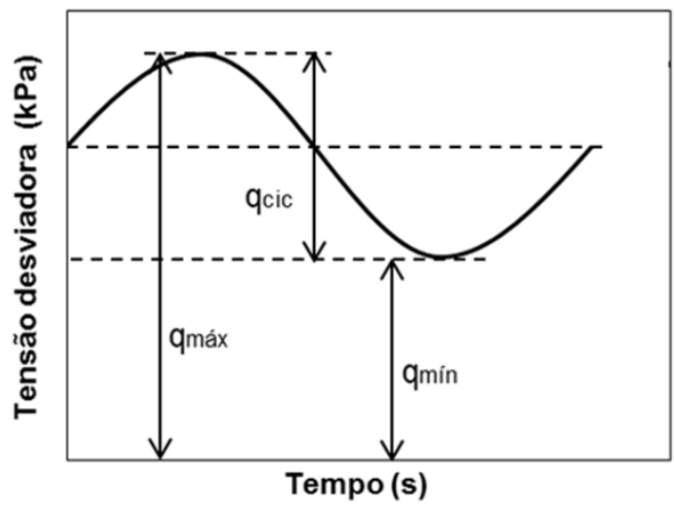

(c)

Figura 39 - (a) Sinal do LVDT bruto; (b) sinal tratado pela Transformada Discreta de Fourier; (c) ciclo de carregamento baseado no sinal

A quantidade mínima de ciclos para cada análise foi determinada a partir de Indraratna e Salim (2005) e Selig e Waters (1994), que descrevem que as maiores deformações acontecem logo nos primeiros ciclos de carregamento, em torno de 20.000 ciclos. Já o número máximo de ciclos de carregamento foi condicionado de modo que o tempo de ensaio não ultrapassasse um dia (evitando-se, desta maneira, que a prensa funcionasse durante a noite sem acompanhamento). Vale ressaltar que nem sempre era necessário executar ensaios durante todo o dia, pois determinadas análises não necessitam de um número tão elevado de ciclos. Cabe mencionar que nos ensaios de deformação permanente foram realizadas diferentes combinações de tensões, sempre se iniciando pelo menor valor escolhido de $\sigma_{d}$ até o 
maior, pois desta forma seria possível ensaiar diferentes condições sem a necessidade de moldar vários corpos de prova (SELIG; WATERS, 1994).

Além da tensão vertical, também foi preciso determinar a tensão de confinamento, tensão esta que influencia de maneira expressiva o comportamento mecânico do lastro, por este se tratar de um material granular. Procurou-se determinar a pressão confinante como sendo um valor coerente com a bibliografia, como o que foi obtido no estudo de campo realizado por Indraratna et al. (2010a), por exemplo. O valor da tensão de confinamento que atua na camada de lastro é difícil de mensurada e, da mesma forma, simulada nos ensaios, devido ao comportamento geostático do material e à ação dinâmica causada pelos trens. Sendo assim, adotou-se uma tensão de confinamento de $65 \mathrm{kPa}$ (que simularia o caso de uma ferrovia com transporte de 27,5 toneladas por eixo), estando tal valor de acordo com relatos de Alva-Hurtado e Selig (1981), Indraratna e Salim (2005) e Indraratna et al. (2010a). Valores de tensão confinante diferentes foram adotados nos ensaios de deformação permanente, que analisaram a variação desta tensão e no ensaio de módulo de resiliência. 


\subsection{RESULTADOS}

\subsubsection{Caracterização física}

Todos os materiais coletados foram homogeneizados e quarteados, conforme descrito na ASTM C702 (2003), sendo dividido em amostras de cerca de $35 \mathrm{~kg}$, com cuidado para que não houvesse perda de finos. A Figura 40 ilustra o aspecto final dos agregados após a homogeneização e o quarteamento.
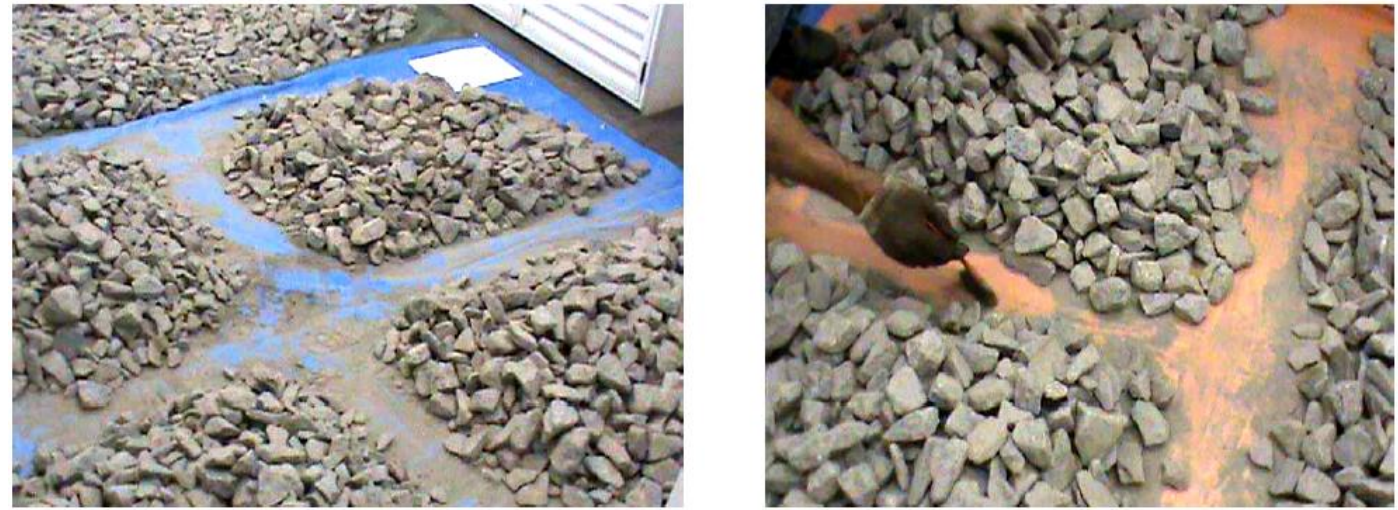

Figura 40 - Homogeneização e quarteamento do material

Após o quarteamento das amostras, procedeu-se aos ensaios para caracterização dos agregados, cujos resultados são apresentados a seguir. Cabe mencionar que estes testes foram realizados de maneira triplicada, permitindo a obtenção de uma média de valores com maior precisão de resultados.

\section{Granulometria}

O ensaio para determinação da distribuição granulométrica foi realizado por peneiramento a seco, após lavagem dos agregados nas peneiras $2 \mathrm{~mm}$ e $0,075 \mathrm{~mm}$ e posterior secagem em estufa, segundo recomendação da ASTM C136 (2006). A Figura 41 apresenta a análise granulométrica dos agregados bem como os limites especificados pela AREMA, para as curvas 24 e 3 . 


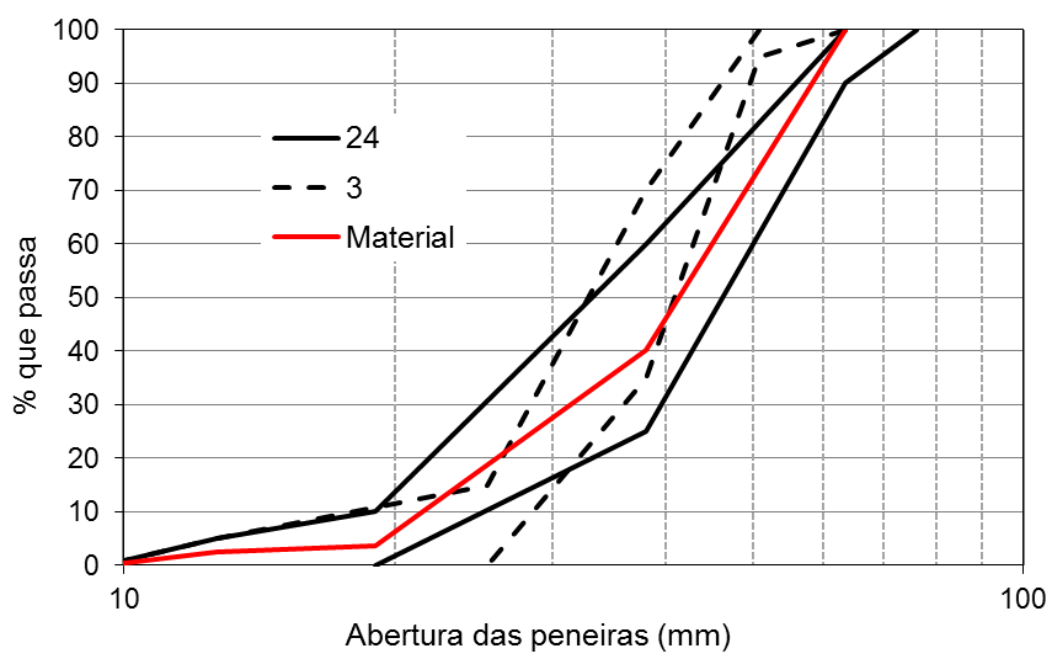

Figura 41 - Curva granulométrica dos agregados coletados no pátio da Vale

Outros parâmetros obtidos com base na análise granulométrica foram o Coeficiente de Uniformidade e o Coeficiente de Curvatura, que correspondem a relações entre os diâmetros de peneiras em que passam 60\%, 30\% e 10\% dos agregados. Nesta pesquisa, os valores de $C_{u}$ e $C_{c}^{6}$ médios encontrados foram de 2,11 e 1,01, respectivamente.

\section{Forma dos agregados}

A determinação da forma dos agregados coletados no pátio da Vale foi feita por duas metodologias, ABNT de acordo com a norma NBR 5564 (2011), e AREMA segundo a norma ASTM D4791. Desta forma todos os agregados de três amostras foram submetidos a ambos os métodos e os resultados exibidos são a média de três análises.

Como estes dois métodos têm diferenças quanto à razão entre dimensões dos grãos sendo 1:2 ou 0,5 para a ABNT e 1:3 ou 0,33 na ASTM, o ensaio foi realizado em ambas as proporções. No total foram avaliados 600 agregados pela ABNT e 1800 pela ASTM.

\footnotetext{
${ }^{6}$ Definição: $\mathrm{C}_{\mathrm{c}}=\frac{(\% \text { pass.D30) })^{2}}{\% \text { pass. } \mathrm{D} 10 . \% \text { pass.D60 }}$
} 
É importante ressaltar que a norma ASTM D4791-10 classifica apenas os fragmentos como: (i) lamelares; (ii) alongados; (iii) alongados-lamelares; e (iv) não alongados e não lamelares. Diferentemente da especificação brasileira que denomina como cúbico o agregado diferente de lamelar e/ou alongado.

A Figura 42 apresenta os resultados médios obtidos quanto à forma dos agregados pela metodologia ABNT e AREMA.

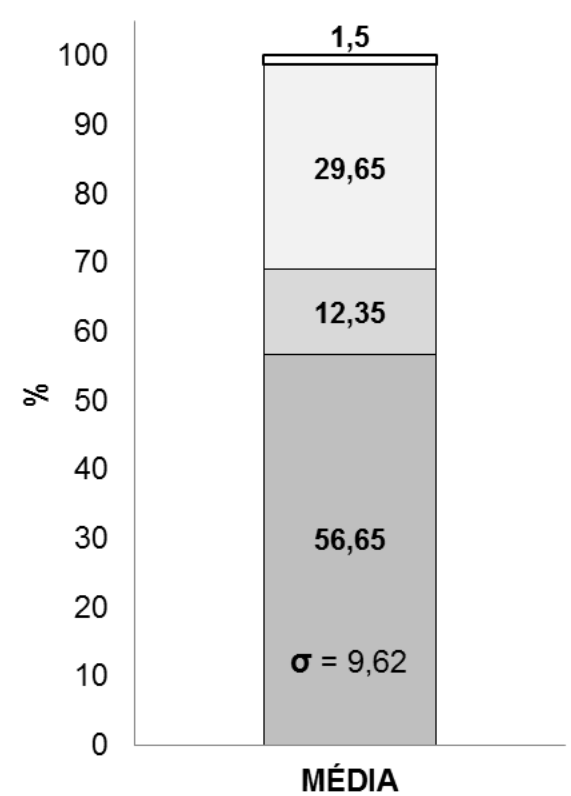

(a)

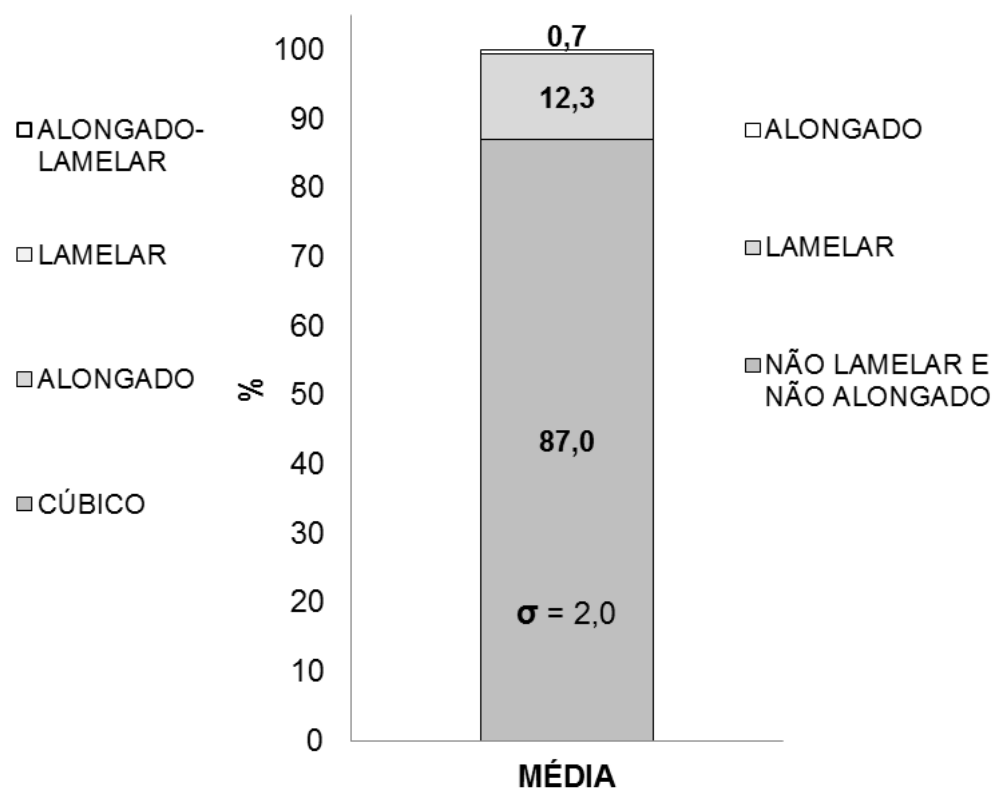

(b)

Figura 42 - (a) Resultado do ensaio de forma dos agregados pela norma ABNT (b) Resultado do ensaio pela norma ASTM

Pelo ensaio realizado pela ABNT, o valor médio de agregados cúbicos foi de $56,25 \%$, com desvio padrão $(\sigma)$ de $9,62 \%$. Tal variação pode estar associada à falta de representatividade do material analisado, seja pelo número reduzido de agregados exigidos para o ensaio (apenas 100 fragmentos da amostra inicial), seja pelo processo de seleção destas amostras, já que esta norma não especifica como deve ser feita esta amostragem, o que pode levar o operador a ser parcial na escolha dos agregados.

Pelo manual da AREMA, as medidas devem ser realizadas por um paquímetro especial que relaciona as medidas de maneira indireta, com os resultados expressos em distribuição quantitativa. Diferentemente dos valores obtidos segundo a norma brasileira, pela ASTM houve uma similaridade de resultados entre as três amostras 
avaliadas, com percentual médio de agregados cúbicos de $87 \%$ e desvio padrão de 2,0\%, o que já era esperado devido à maior representatividade do espaço amostral e ao cuidado tomado na etapa de homogeneização e quarteamento do material para o ensaio, situação que não ocorre na ABNT.

De qualquer modo, deve-se atentar para o fato de que os materiais não cúbicos (lamelares, alongados e alongados-lamelares) compõem uma parte muito significativa da amostra. A ABNT especifica que a fração não cúbica seja no máximo $15 \%$, enquanto a AREMA preconiza que os agregados com forma lamelar e/ou alongada sejam no máximo $5,0 \%$ da amostra. Com isto, conclui-se que a forma dos agregados coletados no pátio da Vale não é adequada.

O material coletado de menor dimensão, utilizado para compor a granulometria decalada, na segunda amostragem junto à pedreira Brasitália, também foi submetido à análise de forma conforme as especificações. O objetivo desta análise era investigar uma possível alteração na forma do material, pois agregados provenientes de rochas de mesma origem mineralógica, mas obtidos por processos de britagem diferentes podem apresentar características distintas (KLINCEVICIUS, 2011).

Como a forma do agregado é um fator que influencia o comportamento mecânico dos materiais granulares, pode haver distinção de resultados entre os ensaios de grande e pequena escala. Agregados com forma cúbica garantem ao conjunto maior resistência ao cisalhamento, pois proporcionam melhor imbricamento (SOUSA PINTO, 2000). Na Figura 43 seguem os resultados da análise de forma, tanto pela norma brasileira como pela especificação norte-americana da segunda amostragem. 


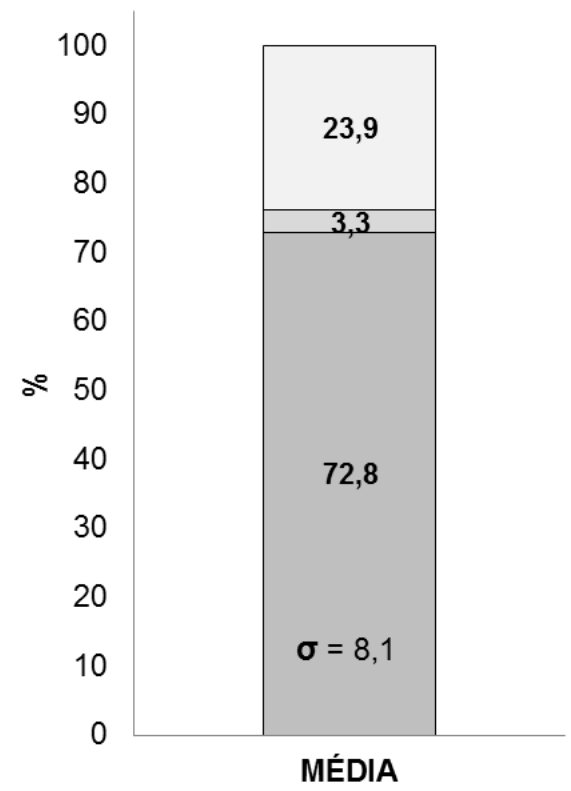

(a)

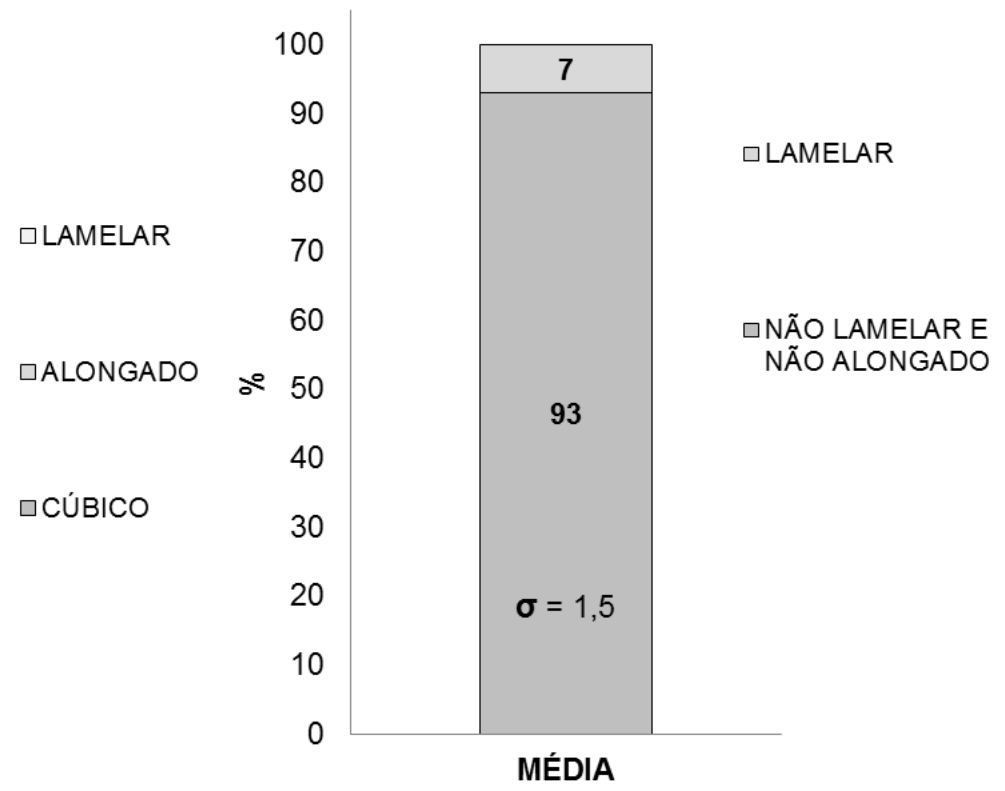

(b)

Figura 43 - Segunda amostragem de agregados (a) Resultado do ensaio de forma pela norma ABNT (b) Resultado do ensaio pela norma ASTM

Pelos resultados percebe-se que os agregados ainda não se enquadram nos limites de aceitabilidade das duas especificações, porém o percentual de agregados cúbicos é superior ao da amostragem ocorrida no pátio da VALE em Cariacica (ES). Esta diferenciação de forma entre os grupos de agregados utilizados é um fator provável que distinguirá os resultados entre os corpos de prova de diferentes dimensões. Entretanto, esta questão poderia ser contornada se a composição dos corpos de prova, em escala real e reduzida, tivesse agregados exatamente com a mesma forma. Contudo, a construção destes corpos de prova exigiria um volume de material muito grande, pois seria necessária a seleção de cada agregado para compor cada amostra. Mesmo assim, considerou-se a composição dos corpos de prova nestas condições, pois se objetiva estudar em laboratório condições similares as de campo (EFVM) e pela diferença de resultado de forma entre o grupo de amostras não ter sido tão distinto.

\section{Porcentagem passante na peneira $n^{\circ} 200$ ou teor de material pulverulento}

A AREMA determina que a porcentagem de material passante na peneira de abertura $0,075 \mathrm{~mm}$ seja de, no máximo, 1,0\%. A especificação ABNT também recomenda este limite, mas se refere a este parâmetro como material pulverulento. $A$ porcentagem passante na peneira 200 ou material pulverulento foi determinada com 
base nas normas ASTM C117 (2004) e ABNT NM 46 (2003) cujos métodos são similares. O resultado médio obtido foi de $0,45 \%$, atendendo assim às especificações.

\section{Massa específica aparente e densidade}

Na especificação da ABNT este parâmetro é tido como massa específica aparente, enquanto na AREMA o mesmo deve ser obtido na forma de densidade (adimensional). Quanto aos valores mínimos recomendados, a ABNT exige $2500 \mathrm{~kg} / \mathrm{m}^{3}$, enquanto a AREMA requer 2,60 respectivamente. Os métodos de ensaio na NBR 5564 (2011) para massa específica e na ASTM C127 (2007) para densidade são bastante similares e diferem somente no que se refere à forma de adição de água aos agregados. Particularmente neste item foram analisadas duas amostras, cujo valor médio foi de $2796 \mathrm{~kg} / \mathrm{m}^{3}$ (massa específica) e 2,80 (densidade específica). Dentro deste contexto, nota-se que o material avaliado atende às especificações.

\section{Absorção de água}

A partir do ensaio de massa específica ou densidade é possível obter também outro parâmetro requisitado nas especificações empregadas: a absorção de água. $\mathrm{Na}$ especificação AREMA a absorção de água não deve ultrapassar 1,0\%, enquanto a norma da ABNT recomenda que este parâmetro não passe de $0,8 \%$. Com base nas normas NBR 5564 (2011) e ASTM C127 (2007), calculou-se o teor de absorção de água pelos agregados, tendo sido encontrado um valor médio de 0,35\% para ambas as normas. Dentro deste contexto, o material avaliado atende às especificações.

\section{Porosidade aparente}

A porosidade é uma propriedade que tem grande relação com a massa específica e com a absorção. Se por um lado, um maior nível de porosidade implica em menor massa específica aparente, a alta porosidade leva a uma maior absorção d'água, elevando a massa específica aparente saturada e diminuindo a resistência mecânica. Na norma ABNT NBR 5564 (2011), acredita-se que haja um equívoco no que se refere a esta questão, pois a mesma recomenda uma porosidade aparente mínima (e não máxima) de 1,5\%. Entende-se que a porosidade deva ser limitada a 
um valor máximo, o que de fato constava na versão anterior da norma da $A B N T$, em 1991 (porosidade aparente máxima =1\%). Neste caso, tendo-se o cálculo com base na norma NBR 5564 (2011), observou-se que a porosidade aparente média dos agregados foi de $0,9 \%$. Nota-se que o material estaria dentro do aceitável perante a especificação, se esta limitasse corretamente a porosidade aparente em no máximo $1,5 \%$.

\section{Resistência à intempérie (ou sanidade)}

Ainda que tenha nomes diferentes, o ensaio de resistência à intempérie na NBR 5564 (2011) e de sanidade na AREMA (ASTM C88, 2005) se refere ao mesmo teste. A diferença entre ambos fica por conta da quantidade de ciclos a que os agregados devem ser submetidos: 40 ciclos pela ABNT e 5 ciclos pela AREMA. Como requisitos, a ABNT exige que após os 40 ciclos o resultado seja inferior a $10 \%$, enquanto na AREMA este não deve ultrapassar $5 \%$ após 5 ciclos.

O resultado deste ensaio apontou que os agregados praticamente não sofreram perda de resistência à intempérie (ou sanidade), ao demonstrarem resultado de $0,1 \%$, para ambos os testes.

\section{Resistência ao choque (Índice de tenacidade Treton)}

O Índice de tenacidade Treton não é um parâmetro exigido pela AREMA, diferentemente da especificação ABNT (NBR 5564, 2011) que requer uma perda máxima de $25 \%$.

O resultado médio de três determinações apontou uma perda de $21 \%$ (com desvio padrão de 1,8\%), atendendo assim a especificação ABNT.

\section{Abrasão Los Angeles}

A determinação da abrasão Los Angeles dos agregados foi feita segundo a ABNT NM 51 (2001), que é equivalente à ASTM C535 (2009). A Tabela 8 apresenta o resultado médio de abrasão Los Angeles do material, bem como o desvio padrão $(\sigma)$. Além disso, também são apontados os limites estabelecidos nas especificações da ABNT e AREMA. 
Tabela 8 - Resultado do ensaio de Abrasão Los Angeles e limites máximos por norma

\begin{tabular}{|c|c|}
\hline Abrasão (\%) & Limite máximo (\%) \\
\hline \multirow{2}{*}{$26,5(\sigma=2,43)$} & ABNT $=30$ \\
\cline { 2 - 2 } & AREMA $=35$ \\
\hline
\end{tabular}

Pelos resultados obtidos nota-se que os agregados se enquadraram dentro dos limites de abrasão Los Angeles perante as normas da ABNT e da AREMA.

\section{Teor de fragmentos macios e friáveis / torrões de argila}

O manual AREMA (2009) recomenda a verificação de torrões de argila e de partículas friáveis em conjunto (ASTM C142, 2004), enquanto a NBR 5564 (2011) considera a análise de torrões de argila, mas a avaliação do teor de fragmentos macios e friáveis como sendo opcional.

A AREMA estipula que os torrões de argila e as partículas friáveis devem compor no máximo $0,5 \%$ do material. Já a ABNT especifica que os torrões de argila e os fragmentos macios e friáveis devem ser no máximo $5 \%$ e 0,5\%, respectivamente. $\mathrm{Na}$ presente pesquisa, a avaliação não apontou a presença de torrões de argila e de materiais friáveis no material coletado no pátio da Vale $(0 \%)$, estando este em acordo com as especificações ABNT e AREMA.

\section{Massa unitária no estado solto}

A especificação AREMA não contempla o ensaio de massa unitária no estado solto, tendo sido este teste introduzido na norma de lastro da ABNT em sua última versão (NBR 5564, 2011). Esta norma requer que o ensaio seja realizado de acordo com a ABNT NBR NM 45 (2006) e tenha como limite 1,25 g/dm³ , embora a unidade esteja erroneamente grafada, devendo ser $\mathrm{g} / \mathrm{cm}^{3}$ e não haja menção se este limite é mínimo ou máximo (acredita-se que seja o mínimo). Para a presente pesquisa foram avaliadas duas amostras, cujo resultado de massa unitária no estado solto médio foi de $1,43 \mathrm{~g} / \mathrm{cm}^{3}$.

Na Tabela 9 têm-se a síntese dos resultados de todos os ensaios de caracterização física que foram realizados, assim como os limites estabelecidos pelas especificações adotadas. 
Tabela 9 - Resumo dos resultados obtidos nos ensaios de caracterização

\begin{tabular}{|c|c|c|c|}
\hline \multirow[t]{2}{*}{ Parâmetro } & ABNT & $\begin{array}{l}\text { AREMA } \\
\text { (Granito) }\end{array}$ & \multirow[t]{2}{*}{ Resultados } \\
\hline & \multicolumn{2}{|c|}{ Limites } & \\
\hline Partículas não cúbicas (1ª coleta) & máx. $15,0 \%$ & - & $43,7 \%$ \\
\hline Partículas não cúbicas ( $2^{\underline{a}}$ coleta) & máx. $15,0 \%$ & - & $27,2 \%$ \\
\hline $\begin{array}{c}\text { Partículas lamelares e/ou alongadas } \\
\left.\text { (1 } 1^{\text {a }} \text { Coleta }\right)\end{array}$ & - & máx. 5,0\% & $13,0 \%$ \\
\hline $\begin{array}{c}\text { Partículas lamelares e/ou alongadas } \\
\text { ( } 2^{\mathrm{a}} \text { Coleta) }\end{array}$ & - & máx. 5,0\% & $7,0 \%$ \\
\hline Forma das partículas & Cúbica & Cúbica & Cúbica \\
\hline$\%$ passante na peneira $n^{\circ} 200$ & - & máx.1,0\% & $0,45 \%$ \\
\hline Material pulverulento & máx. $1,0 \%$ & - & $0,45 \%$ \\
\hline Massa específica aparente & mín. 2500 kg/m³ & - & $2796 \mathrm{~kg} / \mathrm{m}^{3}$ \\
\hline Densidade & - & mín. 2,60 & 2,8 \\
\hline Absorção de água & máx. $0,8 \%$ & máx. $1,0 \%$ & $0,35 \%$ \\
\hline Porosidade aparente & máx. $1,5 \%$ & - & $0,9 \%$ \\
\hline $\begin{array}{c}\text { Resistência à intempérie (ABNT)/ } \\
\text { Sanidade (AREMA) }\end{array}$ & máx. 10,0\% & máx. 5,0\% & $0,1 \%$ \\
\hline $\begin{array}{l}\text { Resistência ao choque (Índice de } \\
\text { tenacidade Treton máximo) }\end{array}$ & máx. 25,0\% & - & $21 \%$ \\
\hline Resistência ao desgaste Los Angeles & máx. 30,0\% & máx. 35,0\% & $26,5 \%$ \\
\hline Teor de fragmentos macios e friáveis & máx. $5,0 \%$ & - & $0 \%$ \\
\hline Torrões de argila & máx. $0,5 \%$ & máx. 0,5\% & $0 \%$ \\
\hline $\begin{array}{l}\text { Limite de massa unitária no estado } \\
\text { solto }\end{array}$ & $1,25 \mathrm{~g} / \mathrm{cm}^{3}$ & - & $1,43 \mathrm{~g} / \mathrm{cm}^{3}$ \\
\hline
\end{tabular}




\subsubsection{Ensaios triaxiais}

Neste item serão descritos os métodos de preparação para os corpos de prova de grande e pequena escala, assim como os resultados, que estão agrupados por análise proposta. Em geral, todos os ensaios seguiram a mesma forma de preparo, exceto os ensaios que tinham como objetivo analisar o efeito da contaminação. Os detalhes da preparação destas amostras contaminadas também seguem neste item.

\section{Preparação dos corpos de prova de verdadeira grandeza}

Os agregados foram divididos e homogeneizados em quatro partes, com massas iguais, de forma a ser executado um corpo de prova em quatro camadas, para minimizar uma possível segregação do material e conferir maior homogeneidade ao corpo de prova.

Após a homogeneização, cada parte era depositada no interior do molde e, posteriormente, vibrada a uma frequência de $20 \mathrm{~Hz}$ durante $40 \mathrm{~s}$. Este processo garantiria um estado de compactação e rearranjo dos agregados similar ao de campo (SELIG; WATERS, 1994; INDRARATNA et al. 2011). Após a compactação das quatro camadas, o corpo de prova tinha sua superfície regularizada para a colocação do top cap. Em seguida, as extremidades do corpo de prova eram vedadas com silicone, tanto na base como no topo.

Terminado o processo de vibração e vedação do corpo de prova, todo o aparato era transportado cuidadosamente pela grua até o atuador, visto que o posicionamento do corpo de prova na bancada é um processo crítico, devido à elevada massa do conjunto.

Por fim, eram colocados ainda dois o-rings de borracha, tanto na base como no topo, para impedir a entrada de ar entre a membrana e o corpo de prova. Em seguida, era feita a aplicação de vácuo para o confinamento, ressaltando-se que tanto a base como o topo possuem válvulas que permitem o controle de saída de ar, garantindo maior segurança ao sistema na ocorrência de algum problema de falta de confinamento. 
A Figura 44 ilustra algumas etapas de preparação do corpo de prova que foram descritas. Ao final deste processo, o corpo de prova já se encontrava preparado para a aplicação de carga.
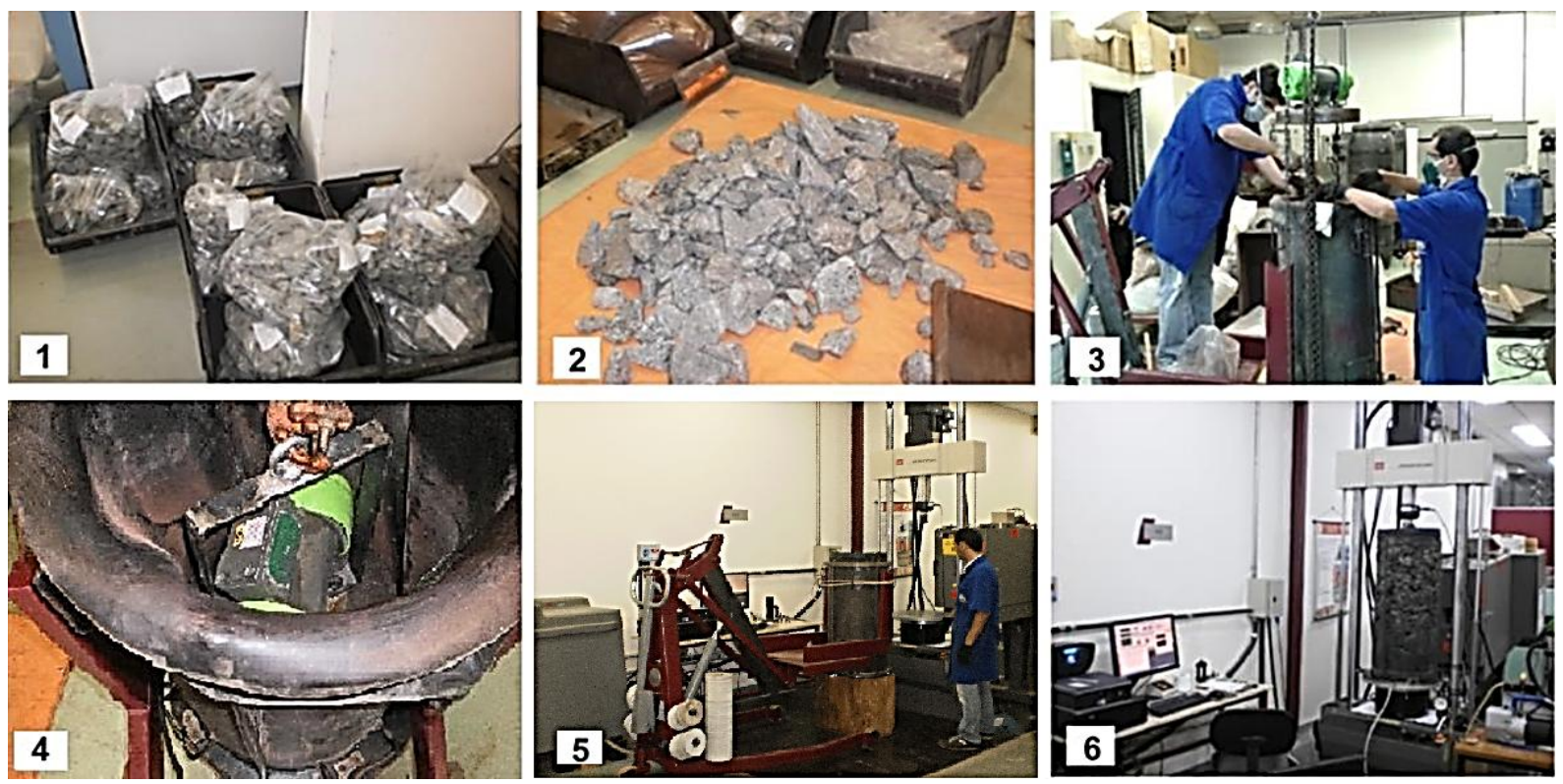

Figura 44 - Etapas de preparação do corpo de prova de grande escala

\section{Preparação dos corpos de prova de pequena escala}

A preparação dos corpos de prova de $150 \mathrm{~mm}$ de diâmetro por $300 \mathrm{~mm}$ de altura seguiu os mesmos princípios daqueles de maiores dimensões. A amostra foi homogeneizada e dividida em quatro camadas, sendo cada camada vibrada com uma frequência de $20 \mathrm{~Hz}$ durante $40 \mathrm{~s}$. A seguir, tem-se a sequência de preparação para estas amostras (Figura 45).
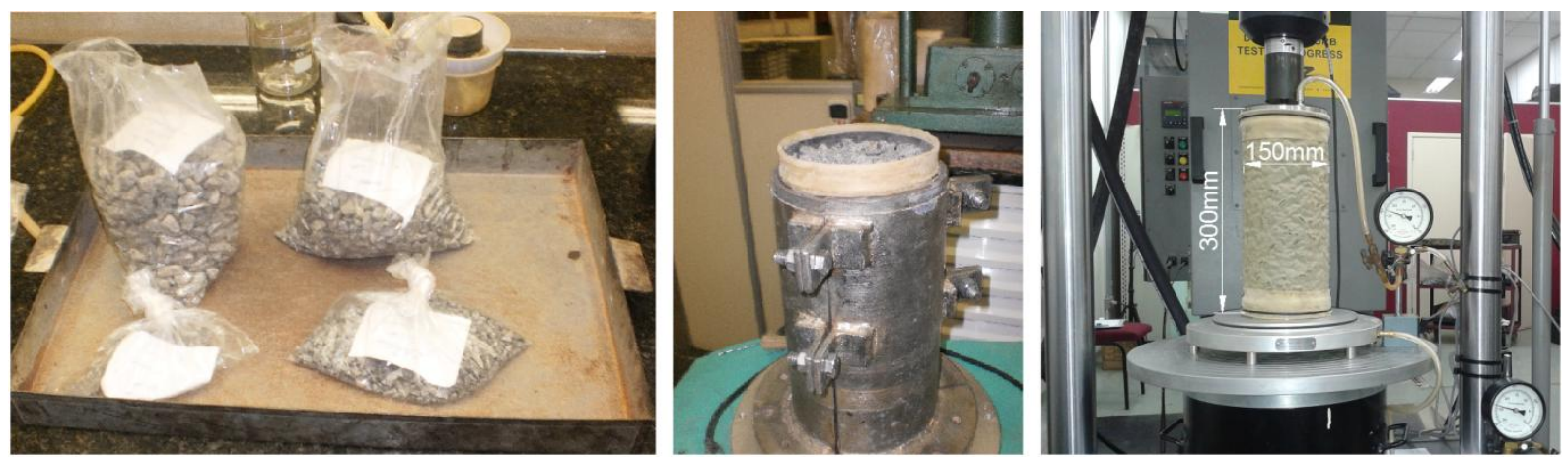

Figura 45 - Preparação da amostra decalada

Para a avaliação de amostras em situação contaminada, esta foi determinada com base na quantidade de finos existentes no lastro coletado na EFVM, na condição 
antes do desguarnecimento ${ }^{7}$, na qual foi verificado que o lastro em questão estava com $23 \%$ de finos. Deste modo, amostras de lastro novo foram contaminadas com $23 \%$ de finos oriundos da via permanente (do material da via), para então serem testadas nos ensaios mecânicos.

Ao preparar amostras de lastro contaminado, o método de introdução de contaminantes é crítico, como citado por Huang et al. (2009) e Ebrahimi (2010) em seus estudos. Embora estes últimos autores tenham adicionado a contaminação ao corpo de prova pré-compactado, nesta pesquisa empregou-se o método de Ebrahimi (2010), onde o material contaminante foi homogeneizado com os agregados de maiores dimensões, sendo então introduzidos por camada, antes da etapa de vibração (Figura 46), pois desta forma conseguiu-se boa homogeneização de todo o material por camada. Este foi o único procedimento adicional ao processo de preparação do corpo de prova, descrito anteriormente.
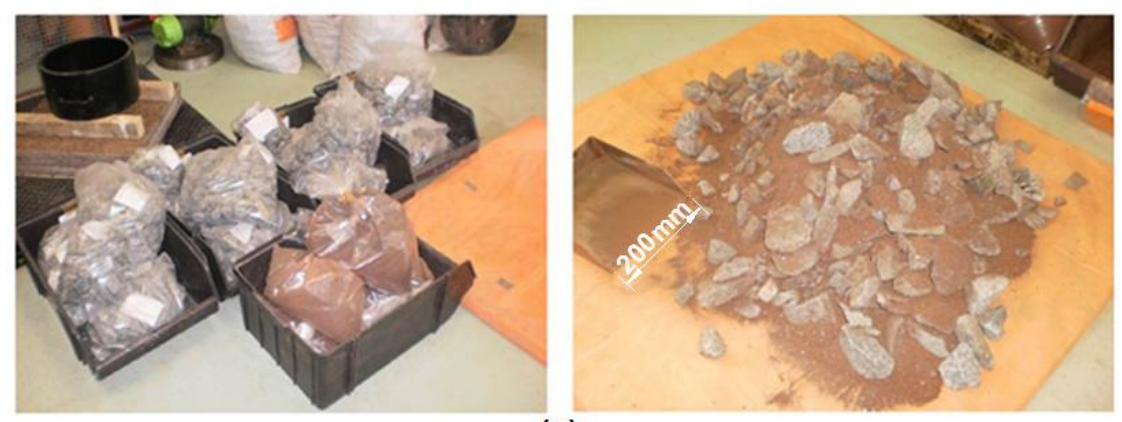

(a)
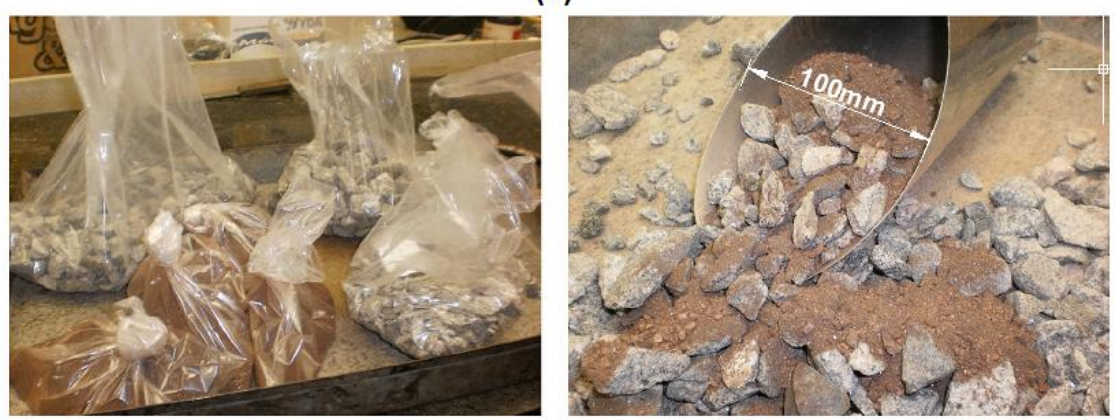

(b)

Figura 46 - Adição de contaminação na amostra (a) escala real; (b) escala reduzida

\footnotetext{
${ }^{7}$ Desguarnecimento - Processo de manutenção, manual ou mecanizado, que visa retornar o lastro ferroviário às características granulométricas adequadas para que as suas funções sejam atendidas. Nesta operação ocorre a retirada do lastro, seu peneiramento para correção granulométrica e retorno à via somente de parcela de material adequado ao reemprego.
} 


\subsubsection{Análise da decalagem}

Com objetivo de analisar a viabilidade de corpos de prova de menores dimensões, por meio da utilização da técnica da decalagem de granulometria, planejou-se a elaboração de três amostras de 150 × 300 mm e três amostras de 400 × 800 mm (Figura 33). Com esta quantidade de testes, espera-se esclarecer algumas questões referentes à técnica de translação de curvas e possibilitar a utilização confiável destes resultados, pois a realização de testes de menor tamanho é mais simplificada quando comparada a ensaios maiores.

Com o objetivo de compreender o comportamento mecânico do lastro com confiabilidade os ensaios desta análise foram programados para deformação permanente ao longo de 290.000 ciclos, subdivididos em quatro níveis de tensões diferentes, com 20.000 ciclos para as duas primeiras combinações ( $\sigma_{1} / \sigma_{3}=3$ e 4$)$, onde os níveis de tensão são baixos e as deformações estabilizam-se rapidamente, e 125.000 para as duas últimas $\left(\sigma_{1} / \sigma_{3}=5\right.$ e 6$)$. O tipo de ciclo aplicado nestes testes seguiu o modelo de Indraratna et al. (2010b). A Tabela 10 resume todos os detalhes dos corpos de prova como: graduação, tipo de material analisado, massa, índice de vazios, etc. A visualização completa das comparações entre amostras estão apresentadas na Figura 33, exibida anteriormente.

Tabela 10 - Detalhe dos corpos de prova

\begin{tabular}{|c|c|c|c|c|c|c|c|c|c|}
\hline Amostra & $\begin{array}{c}\text { Dimensão } \\
(\mathbf{m m})\end{array}$ & $\begin{array}{c}\text { Graduação } \\
\text { (AREMA) }\end{array}$ & Material & $\begin{array}{c}\text { Massa } \\
\mathbf{( k g )}\end{array}$ & $\begin{array}{c}\mathbf{\gamma n} \\
\left(\mathbf{g} / \mathbf{c m}^{3}\right)\end{array}$ & $\boldsymbol{e}$ & $\boldsymbol{n}$ & $\boldsymbol{c u}$ & $\boldsymbol{c} \boldsymbol{c}$ \\
\hline GE I & $400 \times 800$ & 24 & limpo & 172,10 & 1,71 & 0,64 & 0,39 & 2,02 & 0,94 \\
\hline GE II & $400 \times 800$ & 3 & limpo & 169,63 & 1,69 & 0,66 & 0,40 & 1,52 & 0,95 \\
\hline GE III & $400 \times 800$ & 24 & contaminado & 213,94 & 2,13 & 0,42 & 0,29 & 57,71 & 14,65 \\
\hline PE I & $150 \times 300$ & 24 & limpo & 8,52 & 1,61 & 0,74 & 0,43 & 1,98 & 0,99 \\
\hline PE II & $150 \times 300$ & 3 & limpo & 8,44 & 1,59 & 0,76 & 0,43 & 1,60 & 0,97 \\
\hline PE III & $150 \times 300$ & 24 & contaminado & 10,67 & 2,01 & 0,50 & 0,33 & 38,75 & 10,32 \\
\hline
\end{tabular}

Para os níveis de tensão escolhidos, a evolução da deformação permanente axial ao longo do carregamento e a variação do módulo de resiliência podem ser vistos nas Figuras 47 a 49 . Estes resultados foram obtidos para as amostras em escala real GE I e GE II e escala reduzida PE I e PE II, em pares correspondentes, de acordo com a distribuição granulométrica de cada amostra. Dois corpos de prova com as mesmas características, tanto em escala real (GE III) como na reduzida (PE III) 
foram preparados em situação contaminada, pois desta forma também poderia ser realizada além do estudo da decalagem, aqui proposta, a análise da influência da contaminação.

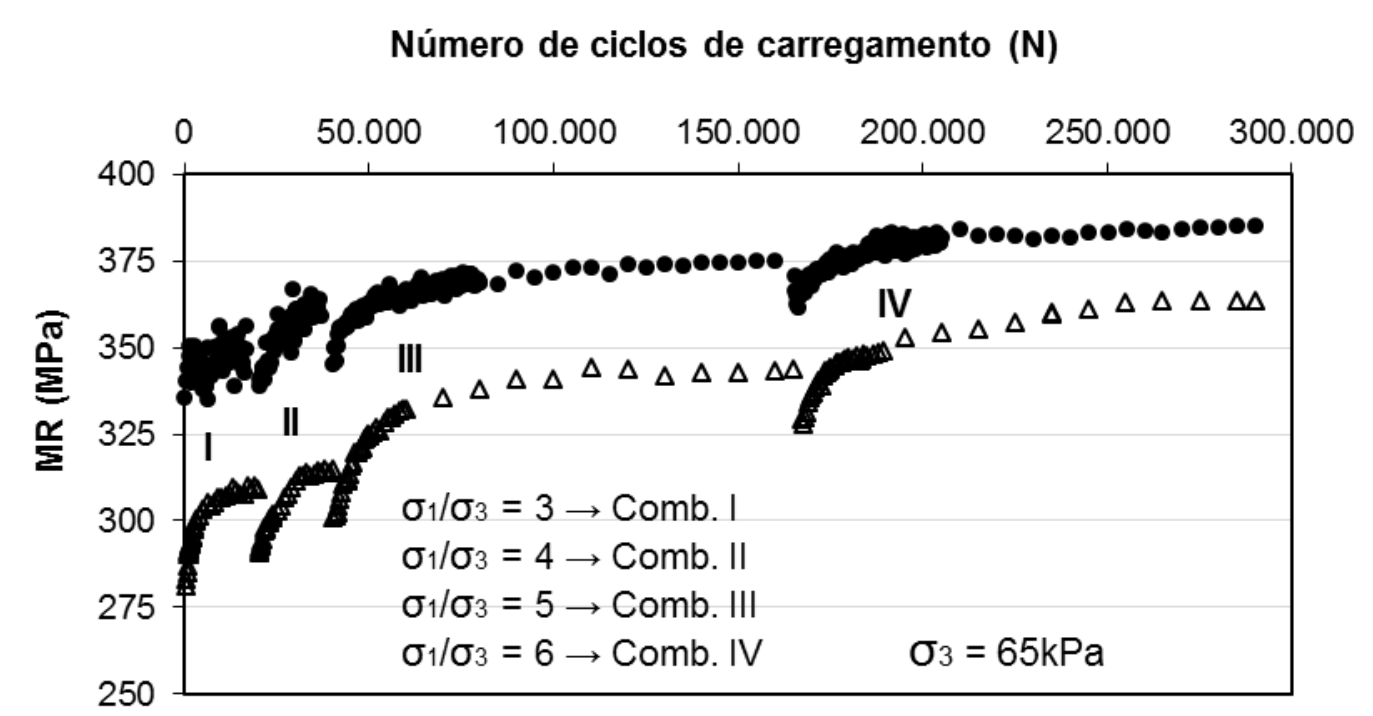

(a)

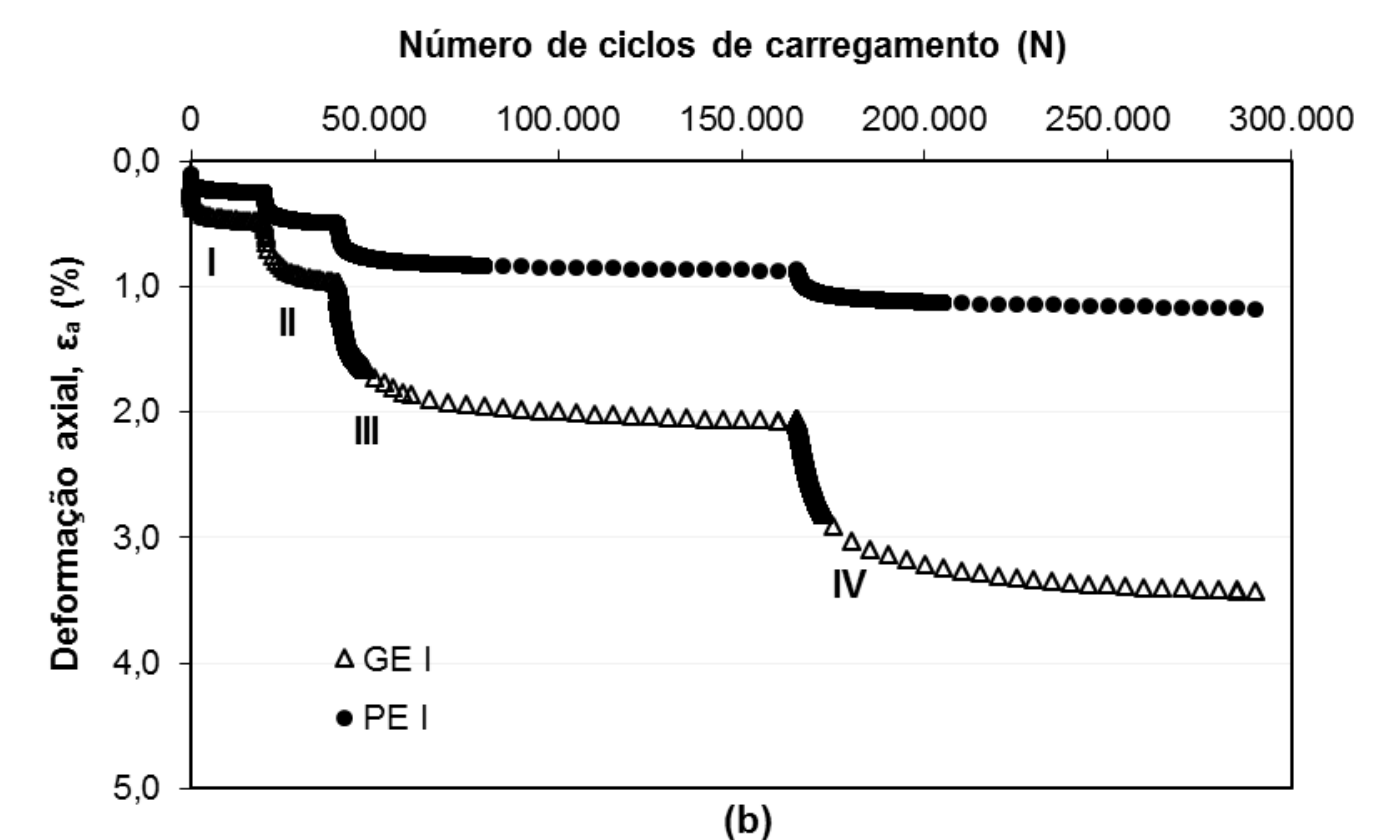

Figura 47 - Resultados dos ensaios cíclicos para amostras GE I X PE I (a) Módulo de resiliência (b) Deformação permanente 


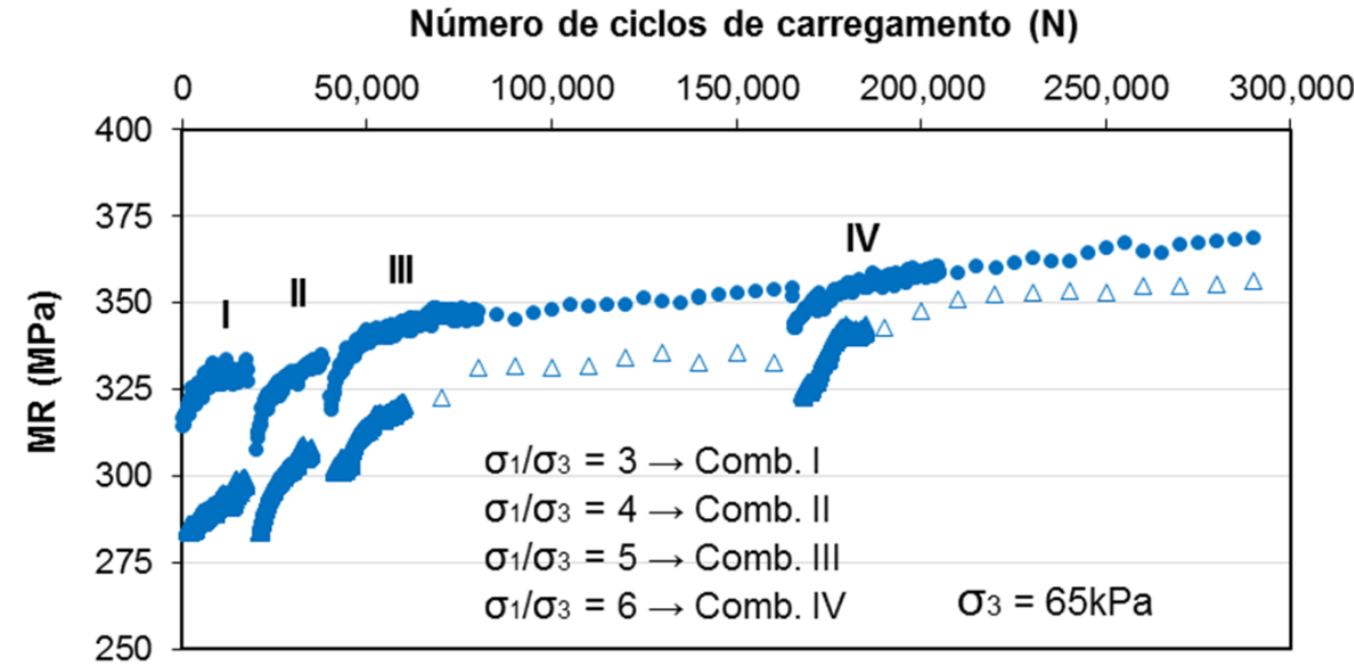

(a)

Número de ciclos de carregamento (N)

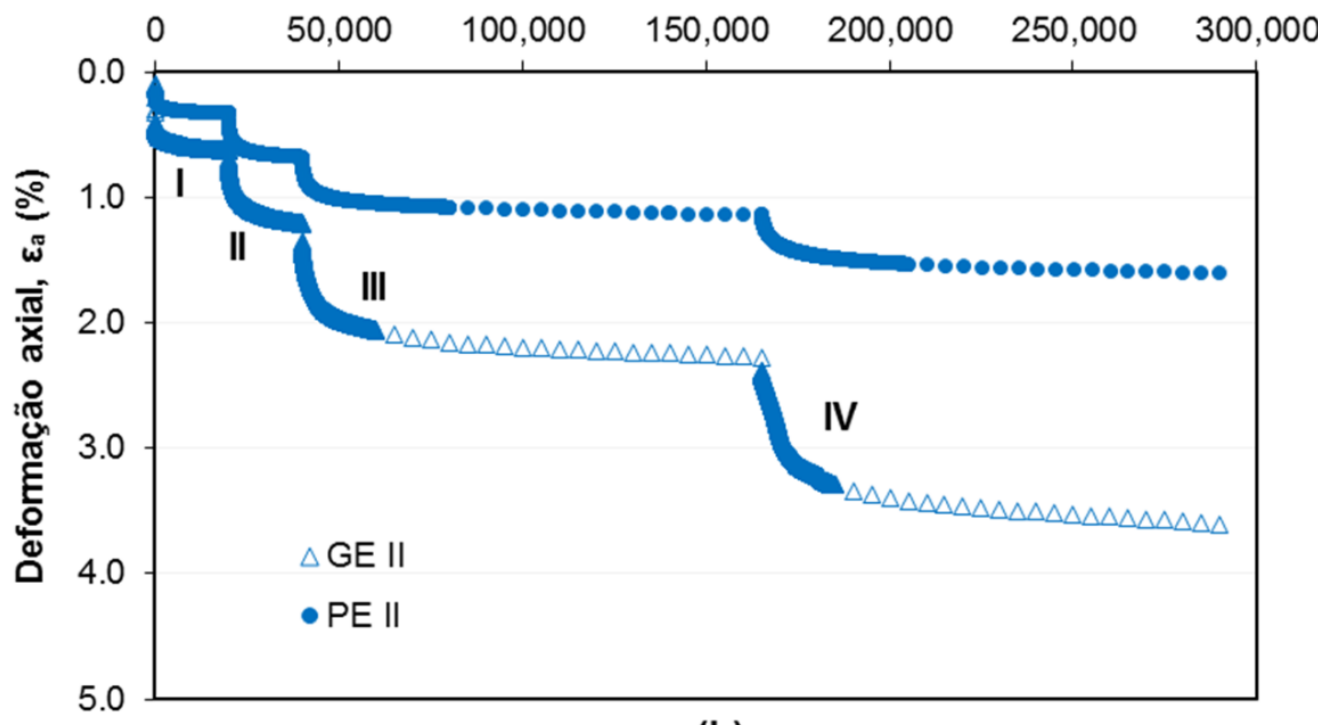

(b)

Figura 48 - Resultados dos ensaios cíclicos para amostras GE II X PE II (a) Módulo de resiliência (b) Deformação permanente 


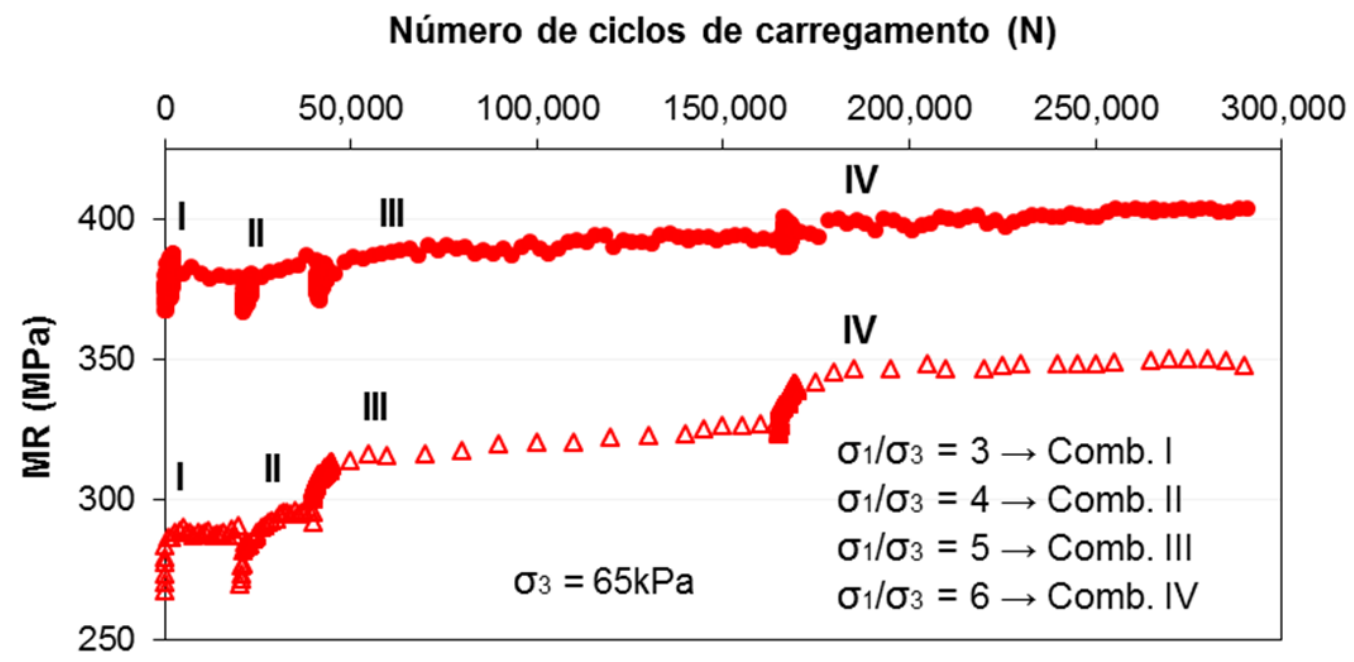

(a)

Número de ciclos de carregamento (N)

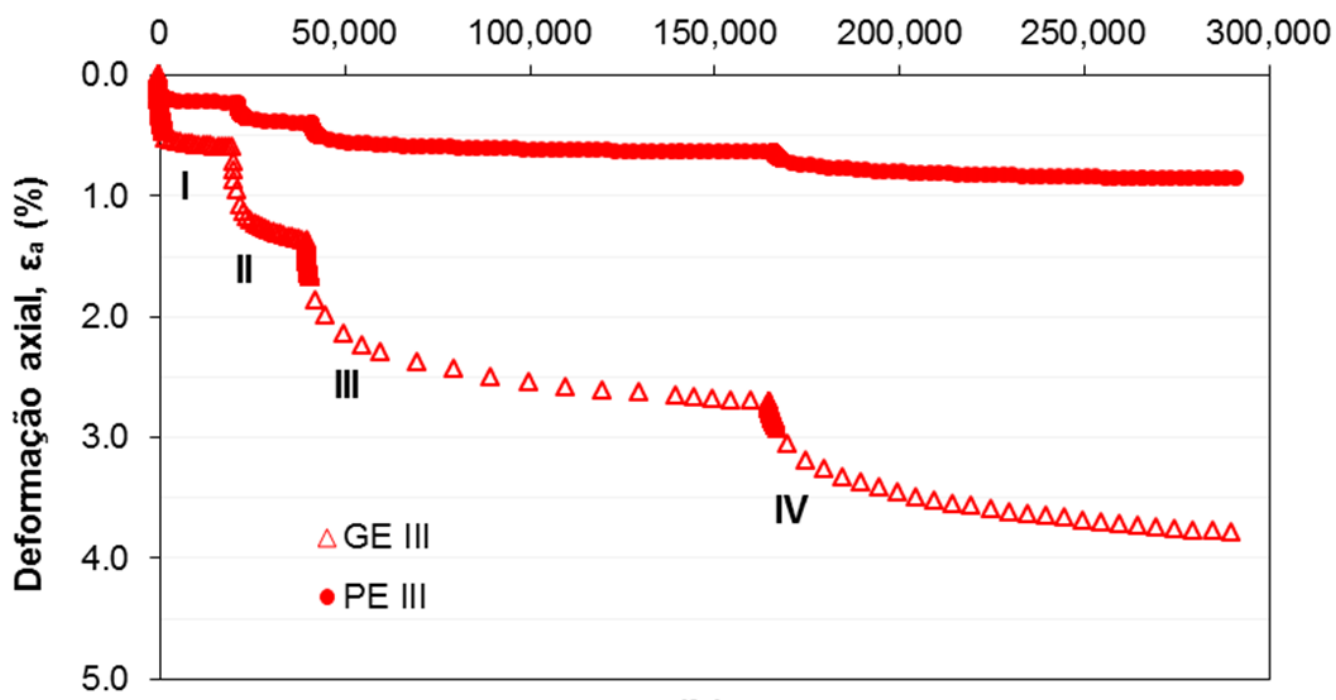

(b)

Figura 49 - Resultados dos ensaios cíclicos para amostras contaminadas GE III X PE III (a) Módulo de resiliência (b) Deformação permanente

Nas quatro combinações de tensões e em todas as amostras percebe-se que o material sempre mostrou estabilização de deformação plástica após os ciclos iniciais. Esta dependência do histórico de tensões, em que o incremento de deformação plástica diminui geralmente com o aumento de ciclos para uma razão de tensões específica, foi percebida por Lim (2004). Destaca-se que as deformações plásticas do lastro se mantêm estabilizadas abaixo desta relação de tensões, porém quando esta é aumentada para níveis nunca antes aplicados, a deformação plástica continua se acumulando até atingir um novo ponto de equilíbrio ou alcançar a ruptura (teoria do shakedown) (WERKMEISTER et al. 2001). 
O efeito direto da alteração da taxa de deformação pode ser percebido pela variação do módulo de resiliência que, em geral, aumenta gradualmente com o número de aplicações de carga, devido ao enrijecimento do material (SEVI, 2008; INDRARATNA; SALIM, 2005), como observado nas Figuras 47(a), 48(a) e 49(a). Nos primeiros ciclos de cada combinação, os módulos de resiliência foram mais baixos, pois é justamente nesta fase que as deformações são maiores por conta da "reacomodação" dos agregados. Após a fase de rearranjo, os valores de módulo de resiliência se elevaram ligeiramente até um nível de estabilização. Observa-se ainda que a tensão desviadora influencia nos resultados de módulo de resiliência, visto que quanto maiores as tensões aplicadas, maiores foram os valores de módulo de resiliência encontrados.

As Figuras 47, 48 e 49 também exibem os resultados obtidos nos ensaios em pequena escala. Percebe-se que a forma de comportamento mecânico se assemelhou às amostras de grande escala, com as maiores deformações acontecendo nos primeiros ciclos. Ressalta-se que as deformações permanentes axiais ocorreram em taxas bem menores que nos ensaios com corpos de prova em verdadeira grandeza. Este efeito já havia sido citado por autores como Sevi et al. (2009), Cambio e Ge (2007) e Varadarajan et al. (2003), e está relacionado a possíveis alterações nas características dos agregados.

Com relação ao comportamento resiliente do material, também foi percebida a mesma característica de redução no módulo de resiliência com aumento das deformações permanentes na etapa de rearranjo, além da estabilização gradual com o aumento do número de aplicações de carga, devido ao enrijecimento do material. Contudo, pela maior rigidez das amostras de escala reduzida, os valores de módulo de resiliência foram superiores, quando comparados às mesmas amostras em maior escala.

Como já relatado anteriormente, como provável causa para esta diferença na taxa de deformação está a forma dos grãos diferenciada entre as amostras, levando a um melhor intertravamento nos corpos de prova em escala reduzida, que possuem maior quantidade de agregados cúbicos. Tal efeito também é percebido pela diferença entre massa especifica $\left(\gamma_{n}\right)$, índice de vazios $(e)$ e porosidade $(n)$ das amostras em grande e pequena escala. Devido à maior resistência ao cisalhamento 
nos ensaios decalados, nestes não se conseguiu o nível de compactação similar às amostras maiores, com o risco de desgaste dos agregados caso um esforço de vibração maior fosse empregado.

De acordo com Lambe e Whitman (1969), o tamanho dos agregados tem influência na resistência dos mesmos. Segundo estes autores, a resistência dos agregados é inversamente proporcional ao tamanho, ou seja, quanto maior for o agregado menor a sua capacidade de resistir esforços. Portanto, a probabilidade de quebra se eleva com um aumento no tamanho do agregado.

Outro fator que justifica a diferença de rigidez entre amostras de diferentes tamanhos também pode ser visto em Lambe e Whitman (1969). Tais autores comentam que a quantidade de pontos de contatos entre agregados tem efeito na resistência final do conjunto. Desta forma, agregados menores proporcionam maior número de pontos de contato entre si e, com isto, amostras constituídas com estes agregados tendem a ser mais resistentes quando comparadas às amostras compostas por agregados maiores, pois os esforços são mais bem distribuídos.

Estudos para a viabilidade de métodos de redução de escalas foram geralmente realizados para materiais de enrocamento de barragens, cujo estado de tensões é muito diferente daquele de uma ferrovia. Quando as tensões são suficientes para quebrar o material, como no caso da via permanente, as diferenças nas características dos agregados influenciam o comportamento mecânico, o que significa que a diminuição de tamanho alterará o comportamento do conjunto.

Estes fatores sempre serão pontos desfavoráveis aos ensaios comparativos em escala reduzida, porém se todas as características físicas forem garantidas entre as amostras, poderá existir um fator de escala que deve ser ajustado com uma quantidade mínima de ensaios, pois boas correlações podem ser extraídas entre amostras em escala reduzida e real por estas apresentarem comportamento mecânico similar. Logo, a técnica de decalagem de graduação, colaboraria muito para o estudo de lastros ferroviários e possibilitaria a realização de ensaios em equipamentos triaxiais convencionais, de menores dimensões. As distribuições granulométricas de todas as amostras, antes e após a ciclagem, são exibidas nas Figuras 50 a 52. 


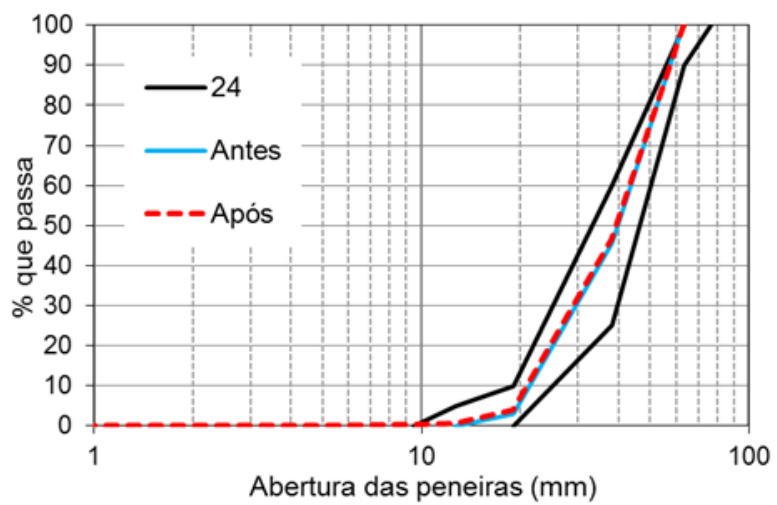

(a)

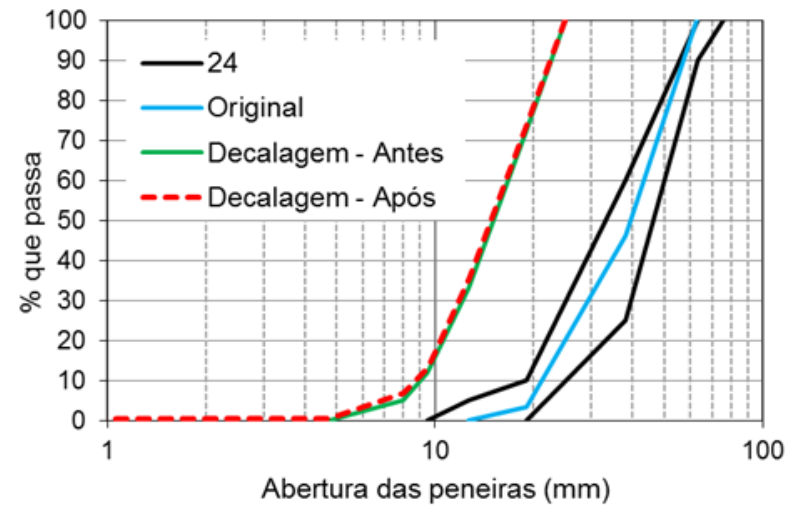

(b)

Figura 50 - Distribuições granulométricas das amostras GE I X PE I (a) escala real; (b) escala reduzida

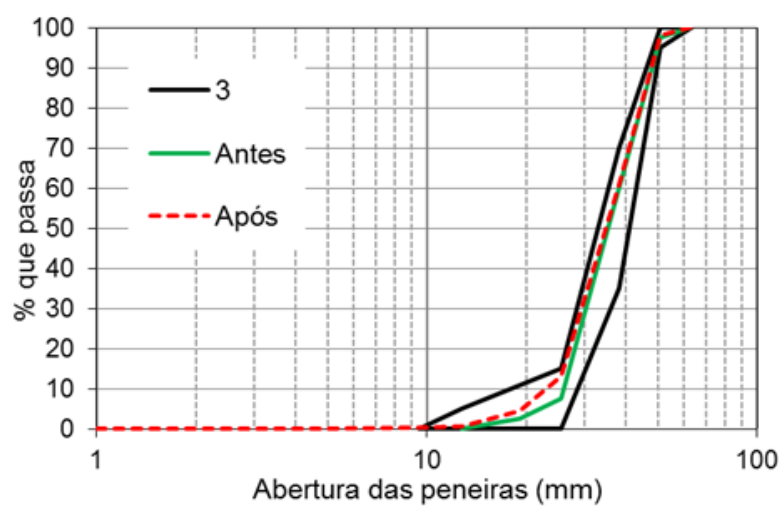

(a)

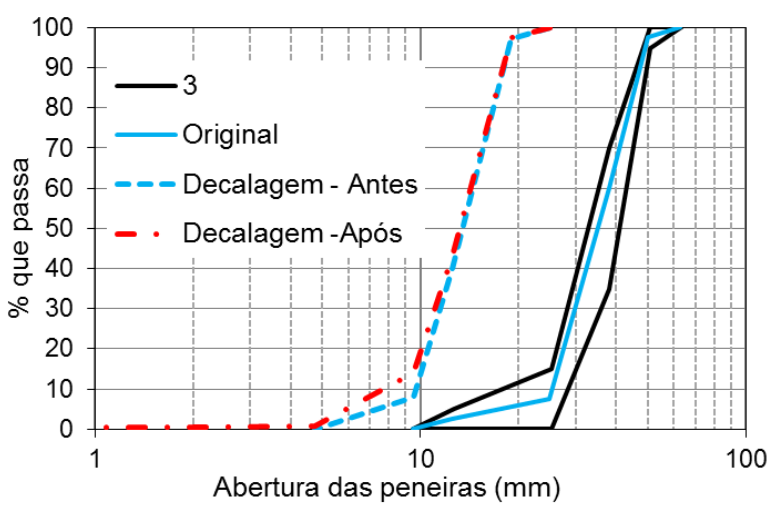

(b)

Figura 51 - Distribuições granulométricas das amostras GE II X PE II (a) escala real; (b) escala reduzida

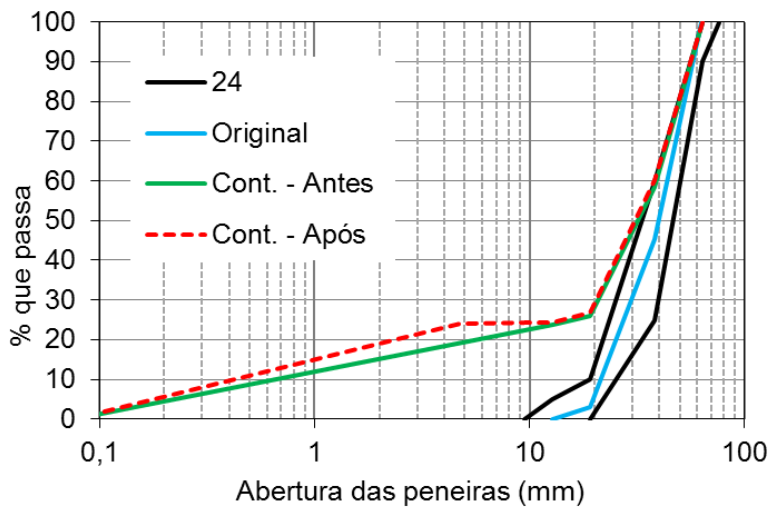

(a)

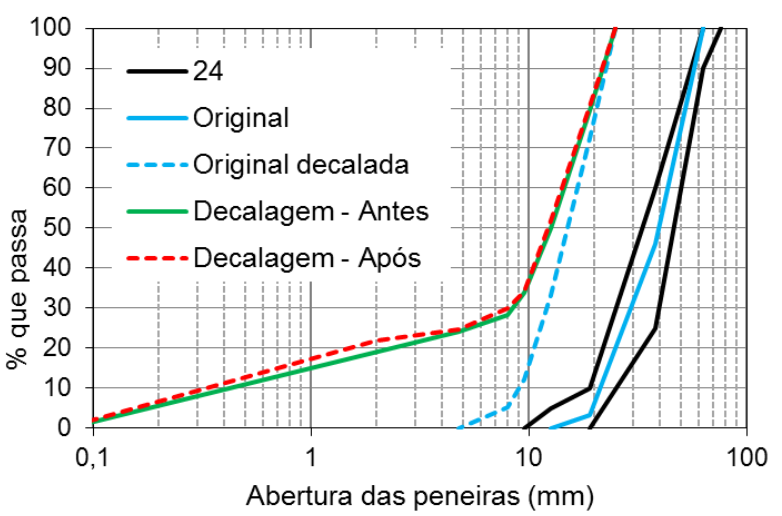

(b)

Figura 52 - Distribuições granulométricas das amostras contaminadas GE III X PE III (a) escala real; (b) escala reduzida 
Pelos resultados de granulometria das amostras após os ensaios, percebe-se que os corpos de prova da graduação AREMA 3 produziram maior fragmentação em comparação as amostras AREMA 24, havendo desgaste proporcional entre os ensaios das diferentes escalas, o que indica satisfatória representatividade entre os resultados das amostras, independentemente do tamanho do corpo de prova. Percebe-se que em todas as amostras houve aparecimento de agregados de dimensões menores, devido à deterioração causada pela ciclagem, entretanto nas amostras contaminadas os níveis foram maiores por causa da presença de finos, o que diminuiu a resistência ao cisalhamento, gerando maior desgaste.

Após os ensaios GE I e GE II, pode-se observar a deterioração do material pela fragmentação dos agregados, conforme ilustrado na Figura 53. Pela imagem, fica claro que o carregamento cíclico, além de causar o rearranjo dos agregados (situação citada anteriormente), também ocasionou quebra dos mesmos, demonstrando que o nível de tensão escolhido e as condições de ensaio são adequados e caracterizam satisfatoriamente o comportamento típico de uma ferrovia.
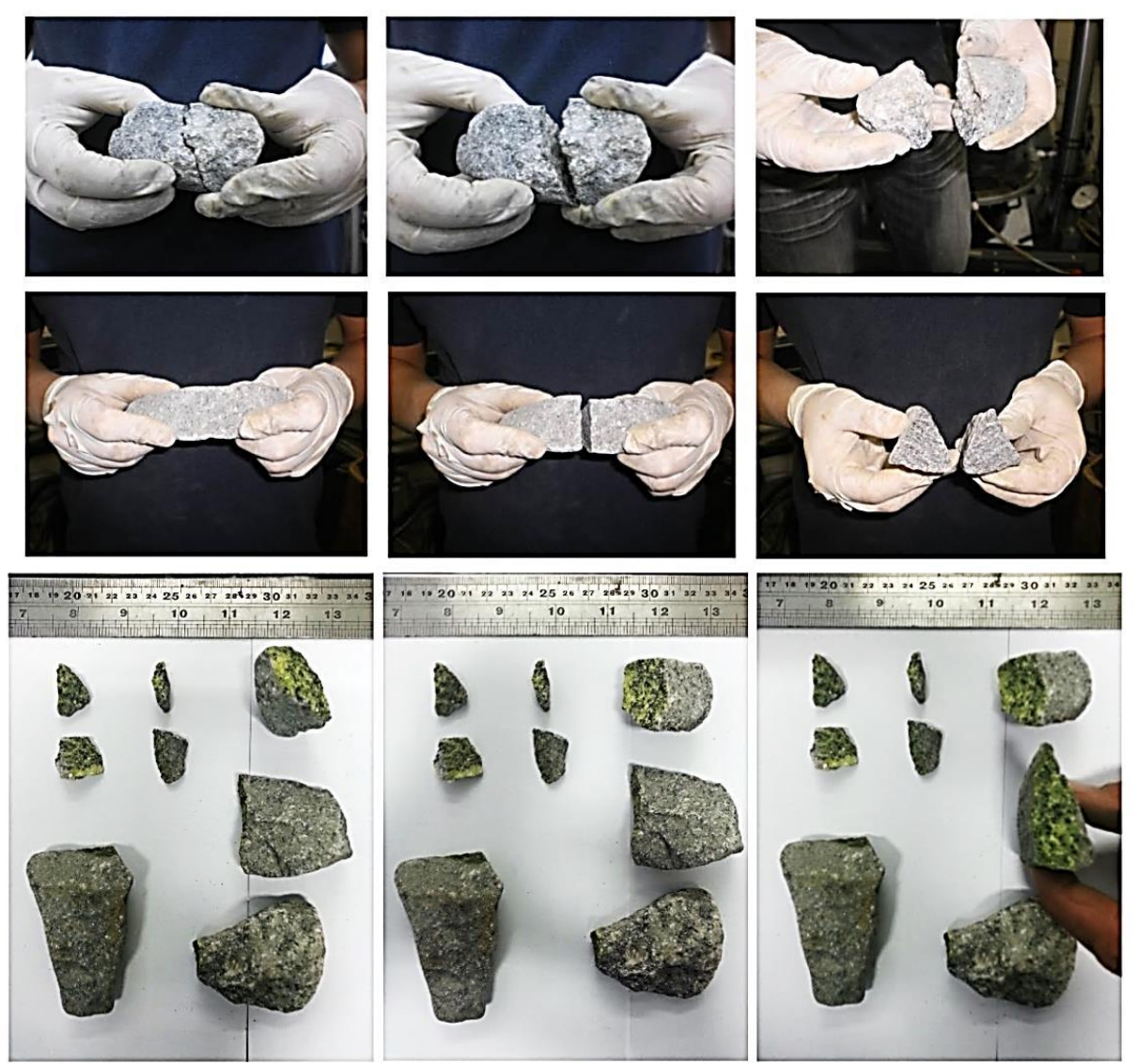

Figura 53 - Agregados deteriorados após os ensaios mecânicos GE I e GE II 
$\mathrm{Na}$ Figura 54, estão exibidos os corpos de prova GE I (AREMA 24) e GE II (AREMA 3). Estão também evidenciados os detalhes dos agregados envolvidos pela membrana de látex após a aplicação da tensão confinante.
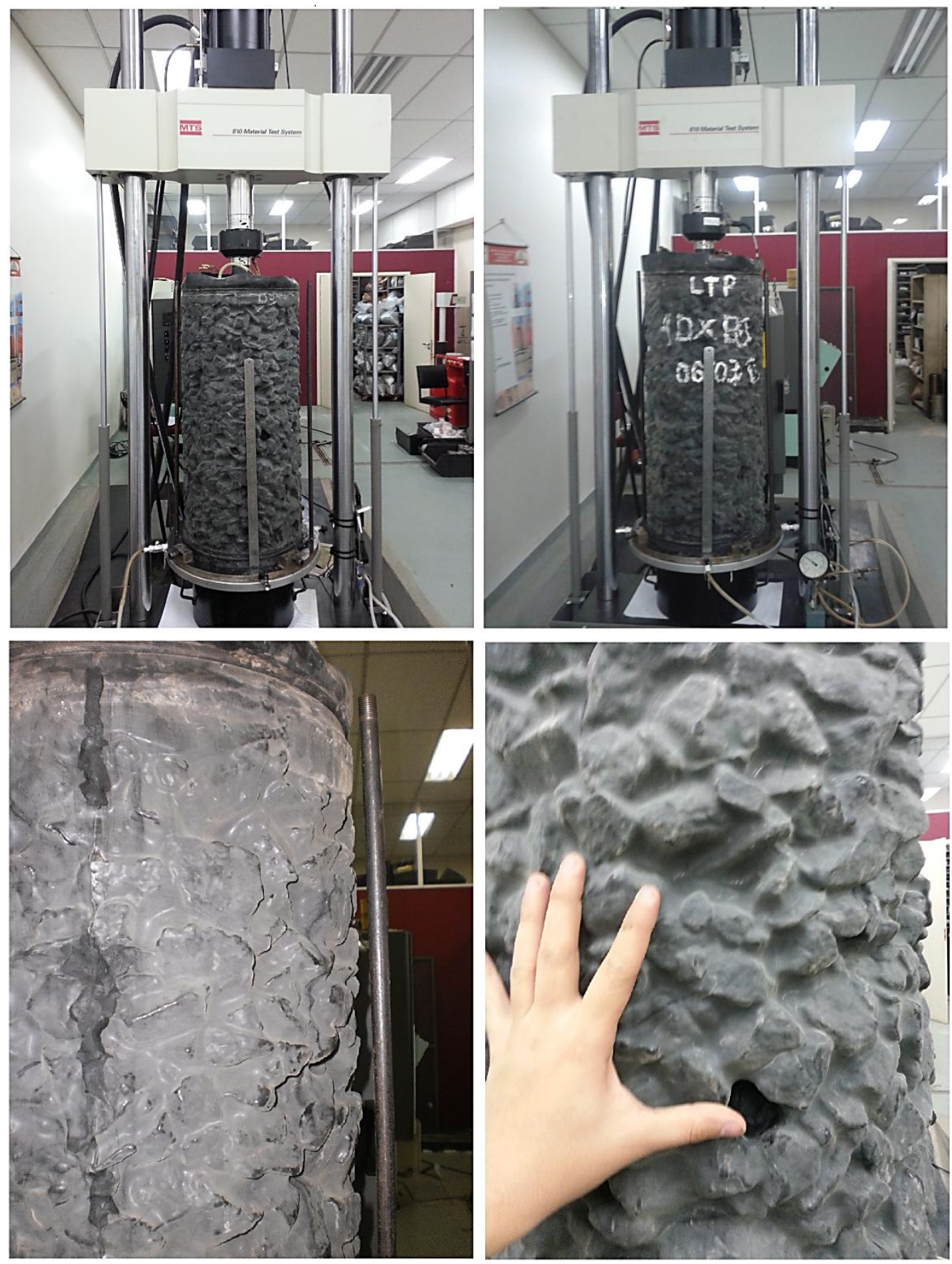

Figura 54 - Detalhe das amostras durante a ciclagem GE I (esquerda) e GE II (direita) 


\subsubsection{Efeito da contaminação}

Para a avaliação da influência da contaminação nos corpos de prova em grande escala, realizou-se dois ensaios, um com material limpo e outro com $23 \%$ de finos, como descrito anteriormente. O efeito da contaminação nas amostras pequenas seguiu o mesmo princípio da amostra em verdadeira grandeza, porém um corpo de prova adicional, com $3,5 \%$ de água, foi testado com o intuito de simular a condição de um lastro contaminado com umidade. A Tabela 11 abaixo resume todos dos detalhes dos corpos de prova para esta análise.

Tabela 11 - Detalhes dos ensaios para análise da contaminação

\begin{tabular}{|c|c|c|c|c|c|c|c|c|c|}
\hline Amostra & $\begin{array}{c}\text { Dimensão } \\
(\mathbf{m m})\end{array}$ & $\begin{array}{c}\text { Graduação } \\
\text { (AREMA) }\end{array}$ & Material & $\begin{array}{c}\text { Massa } \\
(\mathbf{k g})\end{array}$ & $\begin{array}{c}\boldsymbol{\gamma} \boldsymbol{n} \\
\left(\mathbf{g} / \mathbf{c m}^{3}\right)\end{array}$ & $\boldsymbol{e}$ & $\boldsymbol{n}$ & $\boldsymbol{C u}$ & $\boldsymbol{c} \boldsymbol{c}$ \\
\hline GE I & $400 \times 800$ & 24 & limpo & 172,10 & 1,71 & 0,64 & 0,39 & 2,02 & 0,94 \\
\hline GE III & $400 \times 800$ & 24 & contaminado & 213,94 & 2,13 & 0,42 & 0,29 & 57,71 & 14,65 \\
\hline PE I & $150 \times 300$ & 24 & limpo & 8,52 & 1,61 & 0,74 & 0,43 & 1,98 & 0,99 \\
\hline PE III & $150 \times 300$ & 24 & contaminado & 10,67 & 2,01 & 0,50 & 0,33 & 38,75 & 10,32 \\
\hline PE IV & $150 \times 300$ & 24 & $\begin{array}{c}\text { contaminado } \\
\text { úmido }\end{array}$ & 10,53 & 1,99 & 0,58 & 0,37 & 39,23 & 11,27 \\
\hline
\end{tabular}

Na Figura 55, segue a comparação entre as amostras GE I e GE III. Como já era previsto, o corpo de prova com material limpo mostrou menor desenvolvimento de deformações permanentes para todas as combinações de tensões analisadas. No caso do material contaminado, a predisposição a maiores deformações está relacionada à perda de resistência ao cisalhamento pela diminuição do intertravamento entre os agregados. Este fenômeno, provocado pela contaminação excessiva, é muito danoso à estrutura ferroviária e à vida útil do lastro, acarretando no aparecimento de defeitos geométricos, desgaste dos componentes da via e maior recorrência da necessidade de manutenção. 


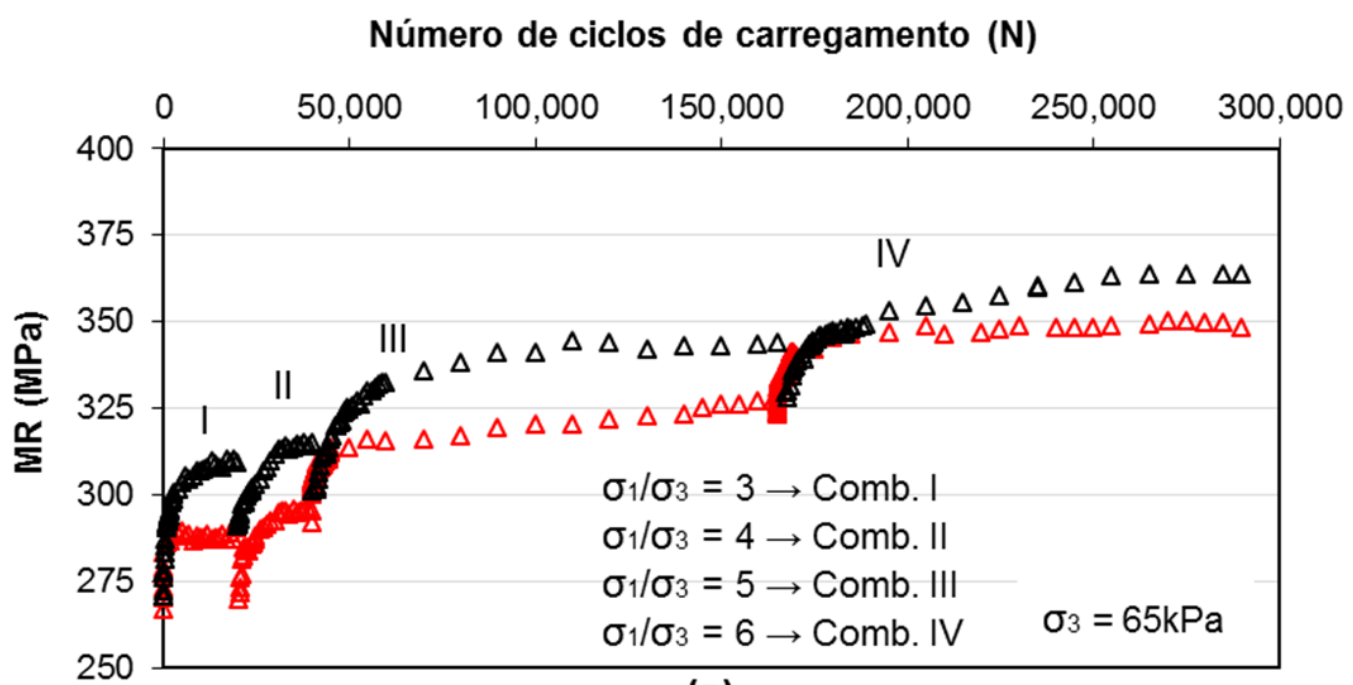

(a)

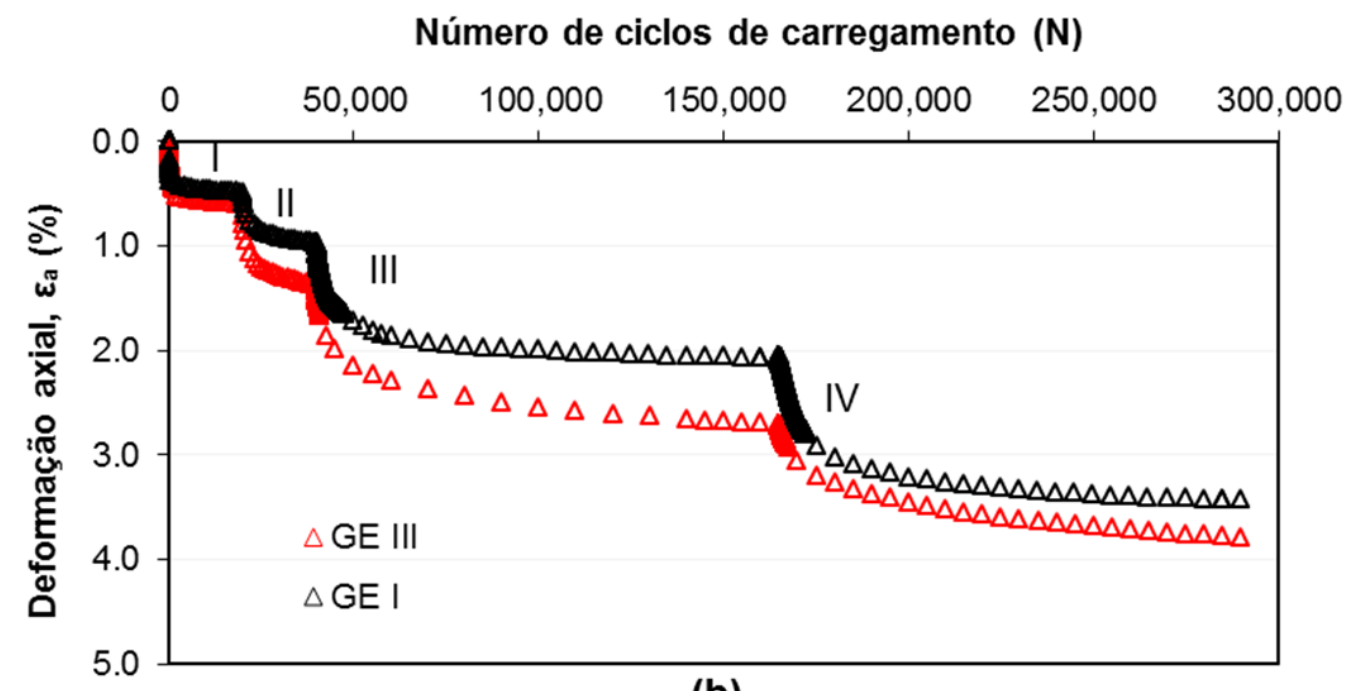

(b)

Figura 55 - Resultado dos ensaios GE I e GE III (a) módulo de resiliência (b) deformação permanente

Pela Figura 55(a) percebe-se um comportamento mecânico semelhante ao que ocorre na via permanente, no qual a camada se deforma com o passar do tempo, ficando cada vez mais rígida, com aumento do módulo de resiliência (INDRARATNA; SALIM, 2005). Contudo, é importante destacar que esta elevação no módulo de resiliência acontece até o ponto em que os finos ainda não comandam o comportamento da matriz do material, pois a partir do momento que esta última começa a reger o comportamento do conjunto, o módulo de resiliência cai por conta do aumento das deformações plásticas (SOUSA PINTO, 2000). Este fato ocorre quando há certa quantidade de finos, em torno de mais de $30 \%$ em massa, produzidos pela quebra do lastro e por contaminações diversas (solo do subleito, 
poeira do ambiente, material que cai dos vagões na via, etc.) (SELIG; WATERS, 1994). Este comportamento é percebido em campo e pode ser potencializado quando os finos entram em contato com água (considerando uma situação de má drenagem, por exemplo). Nestes casos, os finos agem como lubrificantes do contato agregado-agregado e promovem um maior deslocamento do conjunto sob carga, reduzindo o módulo de resiliência.

Em contrapartida, os valores de módulos de resiliência podem aumentar substancialmente caso a quantidade de finos que colmata os vazios do lastro seja expressiva e, assim, este último perca uma considerável quantidade de água, especialmente em períodos de seca. Nestes casos, o material incrustante presente nos vazios do lastro, ao perder umidade, tem sua tensão de sucção elevada, o que também culmina com um aumento no módulo de resiliência. Tal perda de umidade e elevação do módulo de resiliência do lastro é altamente indesejável, pois causam variações de cargas dinâmicas transmitidas à plataforma, desgastes irregulares nos trilhos por heterogeneidade de comportamento mecânico e aumento da rigidez do sistema.

Ainda na Figura 55, é possível notar que, após a fase de rearranjo e estabilização das deformações, o módulo de resiliência das amostras com e sem contaminação resultou em valores próximos entre si. Isto demonstra que o nível de contaminação não foi suficiente para a piora significativa do comportamento elástico após a etapa de rearranjo. Entretanto, vale observar que o material livre de finos exibiu melhor estabilidade ao longo da ciclagem.

Os efeitos da contaminação também foram analisados em amostras de escalas reduzidas, em condição limpa seca, contaminada seca e contaminada com umidade (ensaios PE I, PE III e PE IV, respectivamente) (Figura 56). Para avaliar o efeito da umidade no comportamento do lastro, determinou-se que a amostra seria umedecida com 3,5\% de água. Este valor se deve a questões executivas de ensaio, visto que maiores teores de umidade fariam com que houvesse sucção de água da amostra pela bomba de vácuo e interfeririam no andamento correto do ensaio cíclico. 


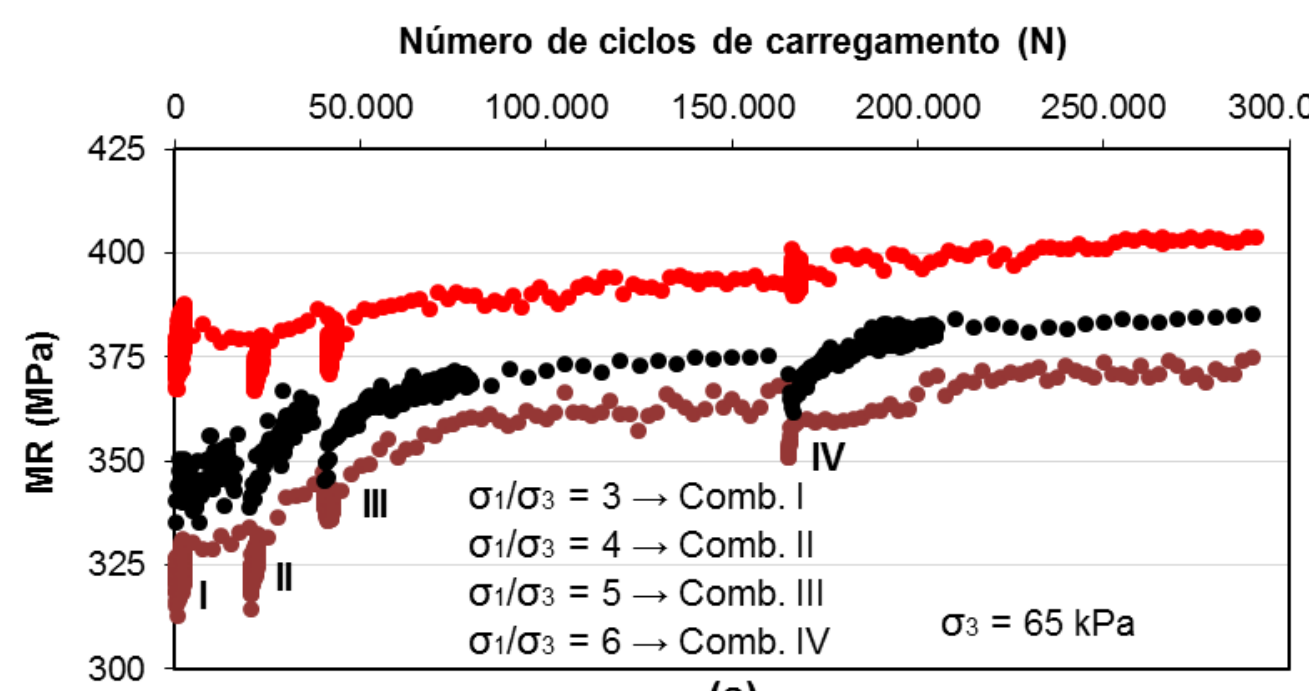

(a)

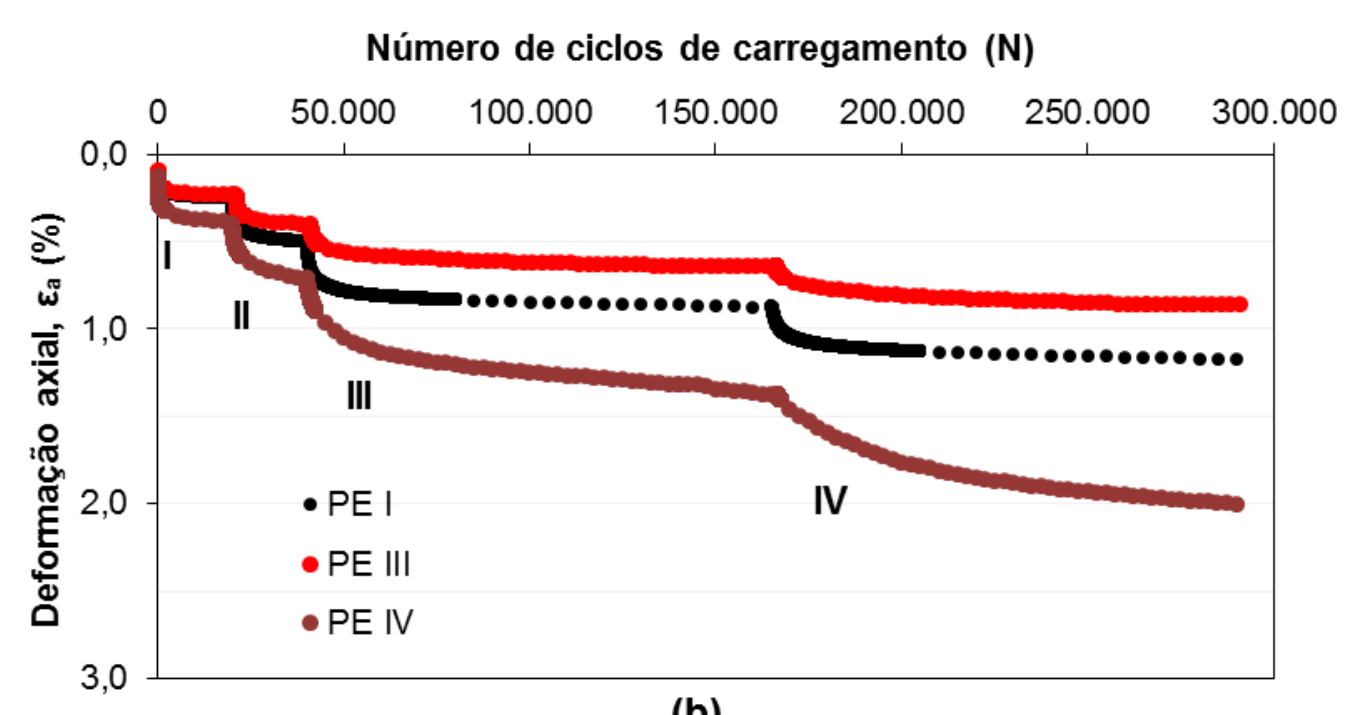

(b)

Figura 56 - Resultado dos ensaios PE I, PE III e PE IV (a) módulo de resiliência (b) deformação permanente

Com a adição de água, percebe-se que as deformações mais que duplicaram, da amostra sem umidade para o corpo de prova úmido (Figura 56b). Com isso, fica claramente evidenciada a mudança no comportamento mecânico de lastro incrustado, quando está submetido à umidade, conforme mencionado anteriormente. Segundo Indraratna et al. (2011), os finos retêm a água e, além de diminuir a rigidez do sistema, provocam um aumento da abrasão entre os agregados maiores. Estes autores também comentam que a situação saturada causa o aumento da pressão de água nos poros e a subsequente queda na resistência ao cisalhamento. A contaminação associada à umidade pode formar bolsões de lama, acelerando a deterioração da camada, dificultando sensivelmente a drenagem e causando 
instabilidade da estrutura. Já em períodos de baixos índices de umidade, quando os vazios do lastro são preenchidos com materiais menos graúdos, ocorre um aumento da rigidez e da estabilidade, porém redução da resiliência, tornando esta variação no comportamento mecânico da subestrutura um fato prejudicial às condições da via.

Outro fato percebido na Figura 56 é que os valores de deformação permanente axial da amostra contaminada seca (PE III) foram inferiores aos da amostra limpa (PE I), situação inversa ao acontecido nas amostras em grande escala. No âmbito do módulo de resiliência, a amostra contaminada apresentou valores superiores àquela limpa. Isto está relacionado ao preenchimento dos vazios pelo material contaminante, ocasionando um enrijecimento ainda maior deste corpo de prova, que já era mais rígido mesmo na situação sem contaminação (fato já discutido anteriormente no item 3.4.2.1). Tal situação evidencia que o estudo da contaminação em amostras em pequena escala fica comprometido, devido às condições físicas do corpo de prova.

A Figura 56(a) mostra ainda os resultados de módulo de resiliência das três amostras, através das quais se observa que a diminuição do módulo de resiliência para a amostra úmida, como ocorrido, era um fenômeno já esperado, pelo mesmo fato já explicado quanto à perda de resistência ao cisalhamento e aumento de deformações permanentes. Sobre o efeito da umidade, Lekarp et al. (2000) indicam que, sob baixos teores de umidade, o módulo de resiliência é pouco alterado, mas este diminui consideravelmente para elevados graus de saturação, tanto menor quanto mais próximo estiver da completa saturação. Entretanto, se percebe neste caso que, mesmo um valor não tão elevado de umidade, já foi o suficiente para alterar consideravelmente o comportamento elasto-plástico do material.

Abaixo seguem as distribuições granulométricas das amostras em grande escala limpa e contaminada, respectivamente (Figura 57). As granulometrias das amostras em escala reduzida utilizadas nesta análise podem ser vistas na Figura 58. 


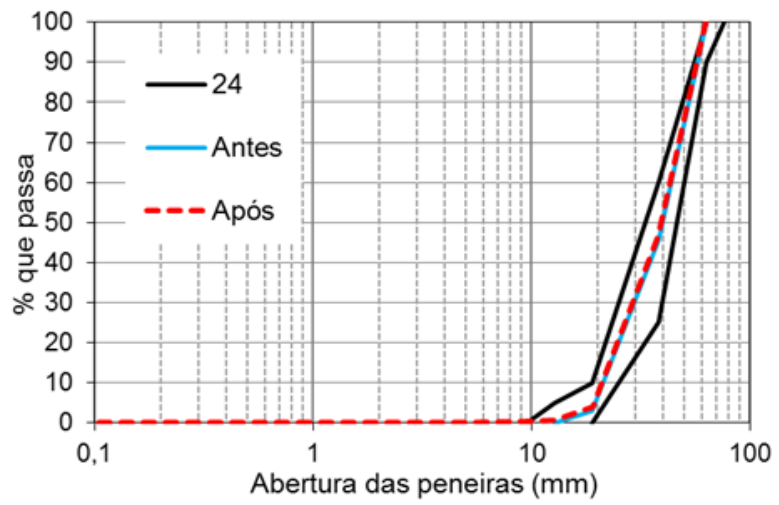

(a)

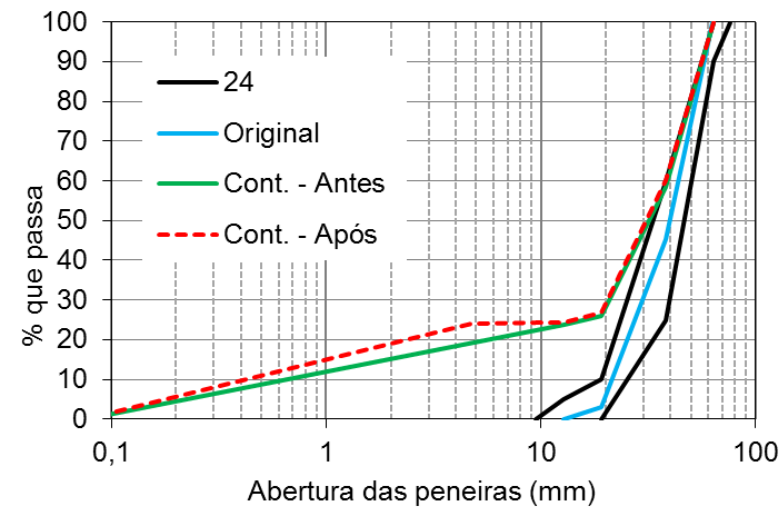

(b)

Figura 57 - Distribuições granulométricas das amostras GE I e GE III (a) escala real sem contaminação; (b) escala real contaminada

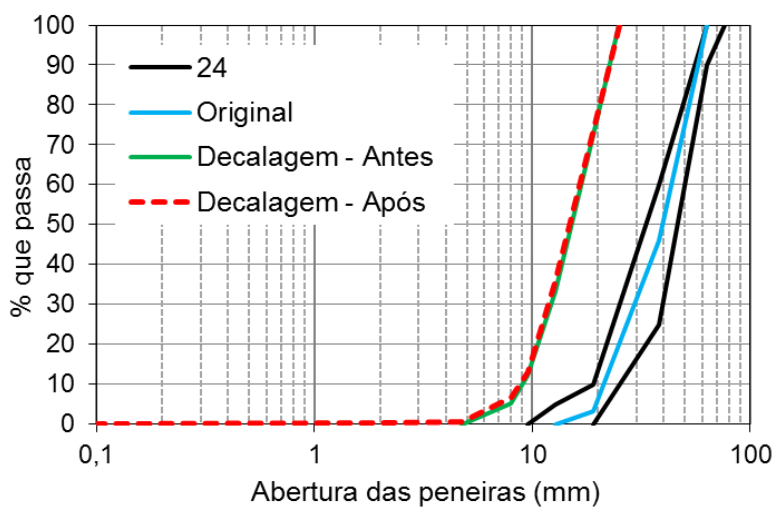

(a)

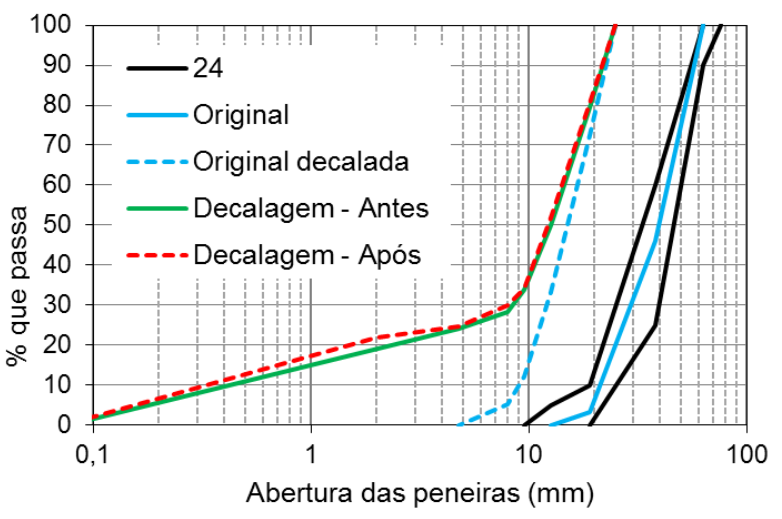

(b)

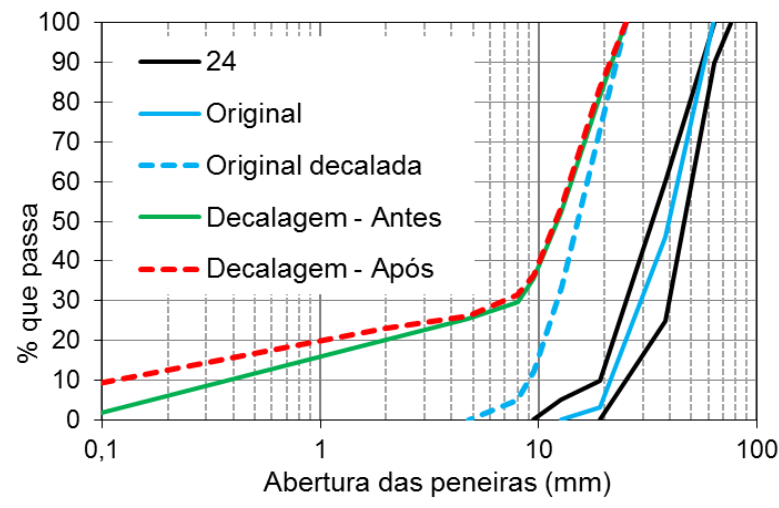

(c)

Figura 58 - Distribuições granulométricas das amostras em pequena escala (a) sem contaminação (PE I); (b) contaminada sem umidade (PE III); (c) contaminada úmida (PE IV) antes e após o ensaio

Com a abrasão aumentada pela presença dos finos, todas as amostras contaminadas apresentaram maior desgaste em todos os ensaios de granulometria realizados após a ciclagem. Ressalta-se que a amostra contaminada com umidade 
apresentou maior nível de deterioração após o ensaio, evidenciando o quão danoso é a associação dos finos com a água, mesmo em níveis relativamente baixos, como no caso deste trabalho. Este fato ocasiona um dos grandes problemas da contaminação dos lastros, que é o aumento da capacidade de retenção de água no interior dos mesmos e a mudança na deformabilidade elástica resultante da presença dos finos. 


\subsubsection{Estudo da granulometria}

A degradação do lastro ferroviário é um dos principais problemas que levam à instabilidade da via férrea, causando colmatação e redução da drenagem. Com isto, a granulometria do material que compõe o lastro torna-se um fator primordial para o correto funcionamento da estrutura da via. Ao se optar pela utilização de uma determinada graduação, consideram-se duas características principais: (i) resistência ao cisalhamento; e (ii) permeabilidade (INDRARATNA et al., 2011). No entanto, cada uma destas características é obtida com granulometrias diferentes. Desta maneira, o objetivo deste item é avaliar o efeito da granulometria na alteração do comportamento mecânico do lastro.

Com intuito de compreender as respostas à deformação de duas diferentes distribuições granulométricas, nōs 24 e 3 da AREMA (que são adotadas pela empresa VALE na EFVM) foram preparadas dez amostras, sendo duas destas em grande escala (detalhes do número de ciclos, tipo de material empregado, forma de ciclo de carregamento e relações de tensões aplicadas foram vistos anteriormente na Tabela 6). A Figura 33 exibe as combinações de ensaios que foram realizados, sempre aos pares, confrontando uma amostra de granulometria AREMA 3 com um de composição AREMA 24. A Tabela 12 resume os detalhes dos corpos de prova como: graduação, tipo de material analisado, massa, índice de vazios (e), porosidade, $C_{u}$ e $C_{c}$.

Tabela 12 - Detalhes dos ensaios para o estudo da granulometria

\begin{tabular}{|c|c|c|c|c|c|c|c|c|c|}
\hline Amostra & $\begin{array}{c}\text { Dimensão } \\
(\mathbf{m m})\end{array}$ & $\begin{array}{c}\text { Graduação } \\
(\text { AREMA) }\end{array}$ & Material & $\begin{array}{c}\text { Massa } \\
(\mathbf{k g})\end{array}$ & $\begin{array}{c}\boldsymbol{\gamma} \boldsymbol{n} \\
\left(\mathbf{g} / \mathbf{c m}^{\mathbf{3}}\right)\end{array}$ & $\boldsymbol{e}$ & $\boldsymbol{n}$ & $\boldsymbol{c u}$ & $\boldsymbol{c} \boldsymbol{c}$ \\
\hline GE I & $400 \times 800$ & 24 & limpo & 172,10 & 1,71 & 0,64 & 0,39 & 2,02 & 0,94 \\
\hline GE II & $400 \times 800$ & 3 & limpo & 169,63 & 1,69 & 0,66 & 0,40 & 1,52 & 0,95 \\
\hline PE I & $150 \times 300$ & 24 & limpo & 8,52 & 1,61 & 0,74 & 0,43 & 1,98 & 0,99 \\
\hline PE II & $150 \times 300$ & 3 & limpo & 8,44 & 1,59 & 0,76 & 0,43 & 1,60 & 0,97 \\
\hline PE V & $150 \times 300$ & 24 & limpo & 8,52 & 1,61 & 0,74 & 0,43 & 1,99 & 0,98 \\
\hline PE VI & $150 \times 300$ & 24 & limpo & 8,51 & 1,61 & 0,74 & 0,43 & 1,98 & 0,98 \\
\hline PE VII & $150 \times 300$ & 3 & limpo & 8,45 & 1,59 & 0,76 & 0,43 & 1,60 & 0,97 \\
\hline PE VIII & $150 \times 300$ & 3 & limpo & 8,44 & 1,59 & 0,76 & 0,43 & 1,59 & 0,98 \\
\hline PE IX & $150 \times 300$ & 24 & limpo & 8,52 & 1,61 & 0,74 & 0,43 & 1,98 & 0,98 \\
\hline PE X & $150 \times 300$ & 3 & limpo & 8,44 & 1,59 & 0,76 & 0,43 & 1,60 & 0,97 \\
\hline
\end{tabular}


Os quatro primeiros ensaios triaxiais cíclicos realizados para simular a passagem de trens, considerando duas distribuições granulométricas distintas, a fim de fornecer informações sobre o comportamento elasto-plástico do material de lastro, estão dispostos em uma comparação direta entre grande escala e outra em pequena escala. Os resultados de módulo de resiliência e deformação permanente axial em função do número de aplicações de carga são apresentados nas Figuras 59 e 60.
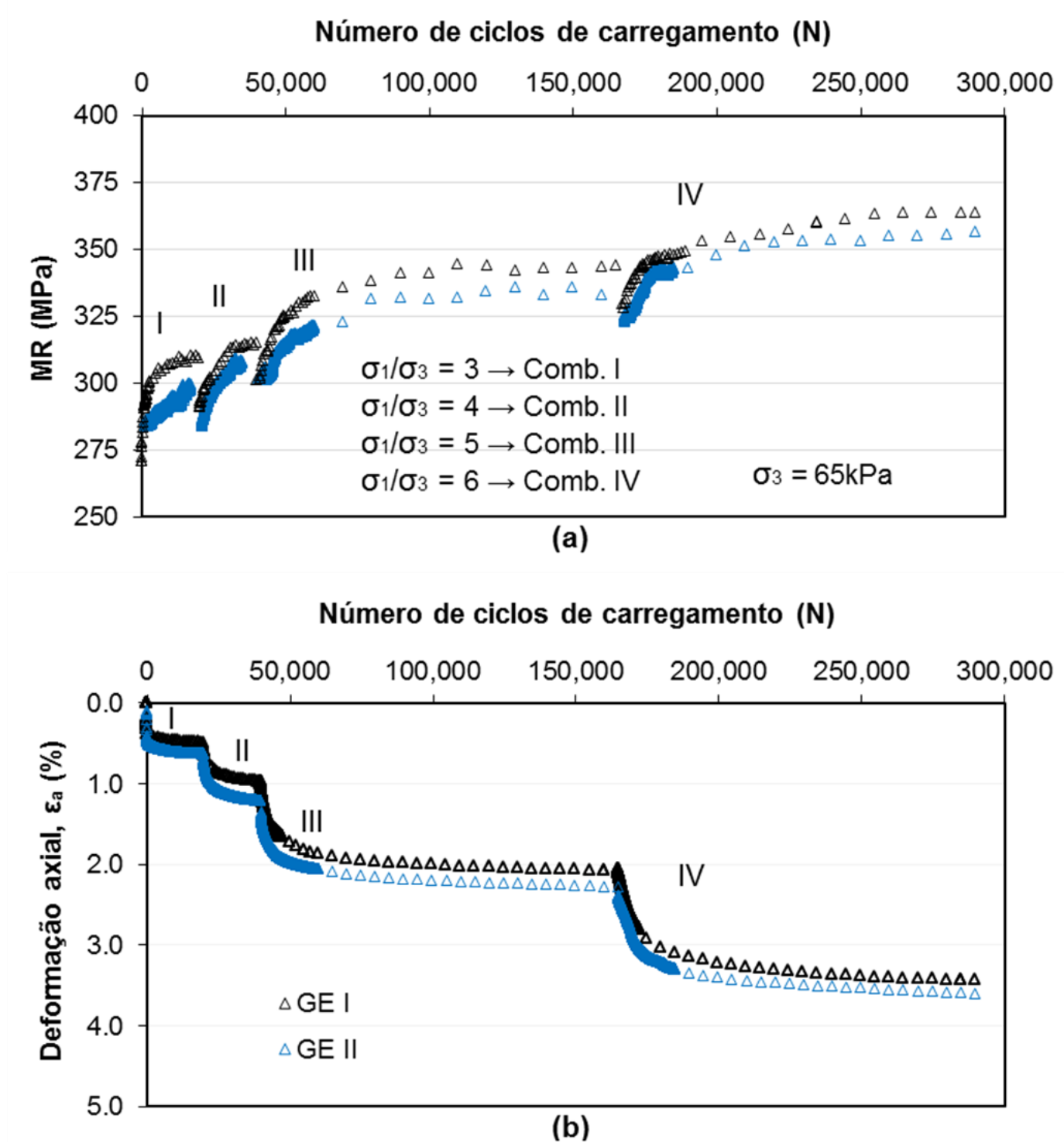

Figura 59 - Resultado dos ensaios GE I (AREMA 24) e GE II (AREMA 3) (a) módulo de resiliência (b) deformação permanente axial 


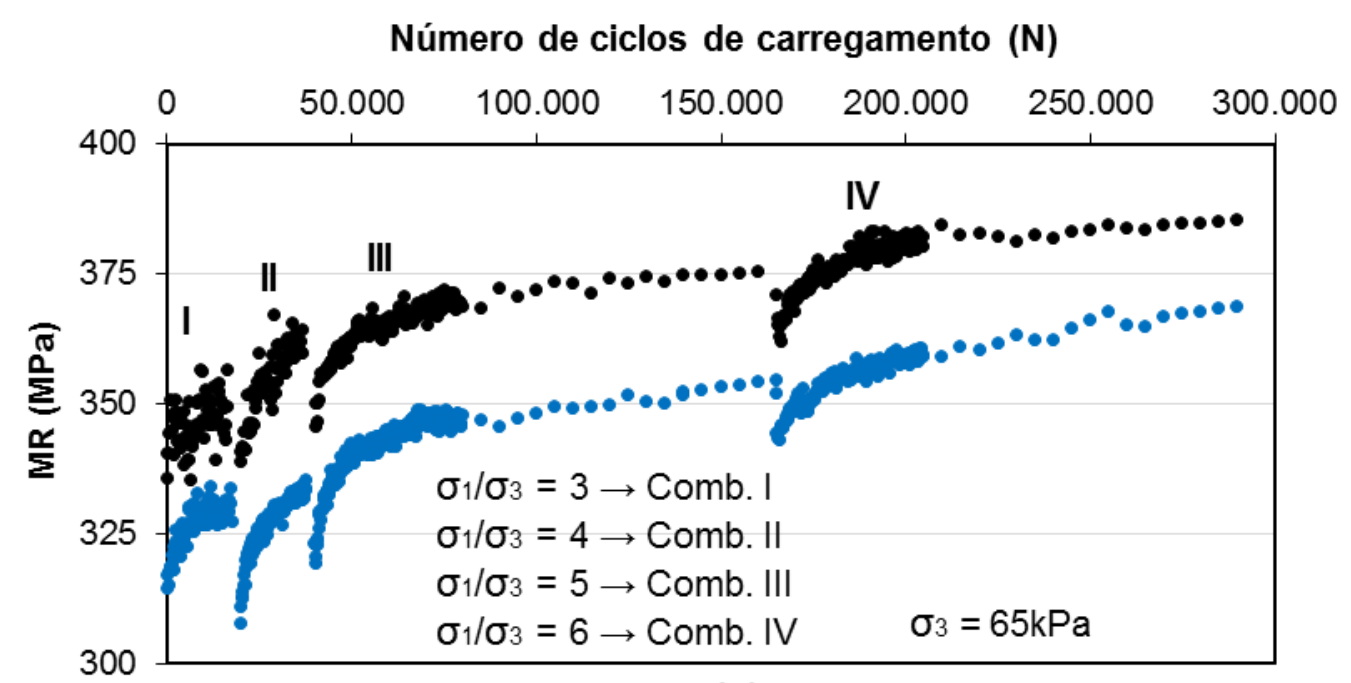

(a)

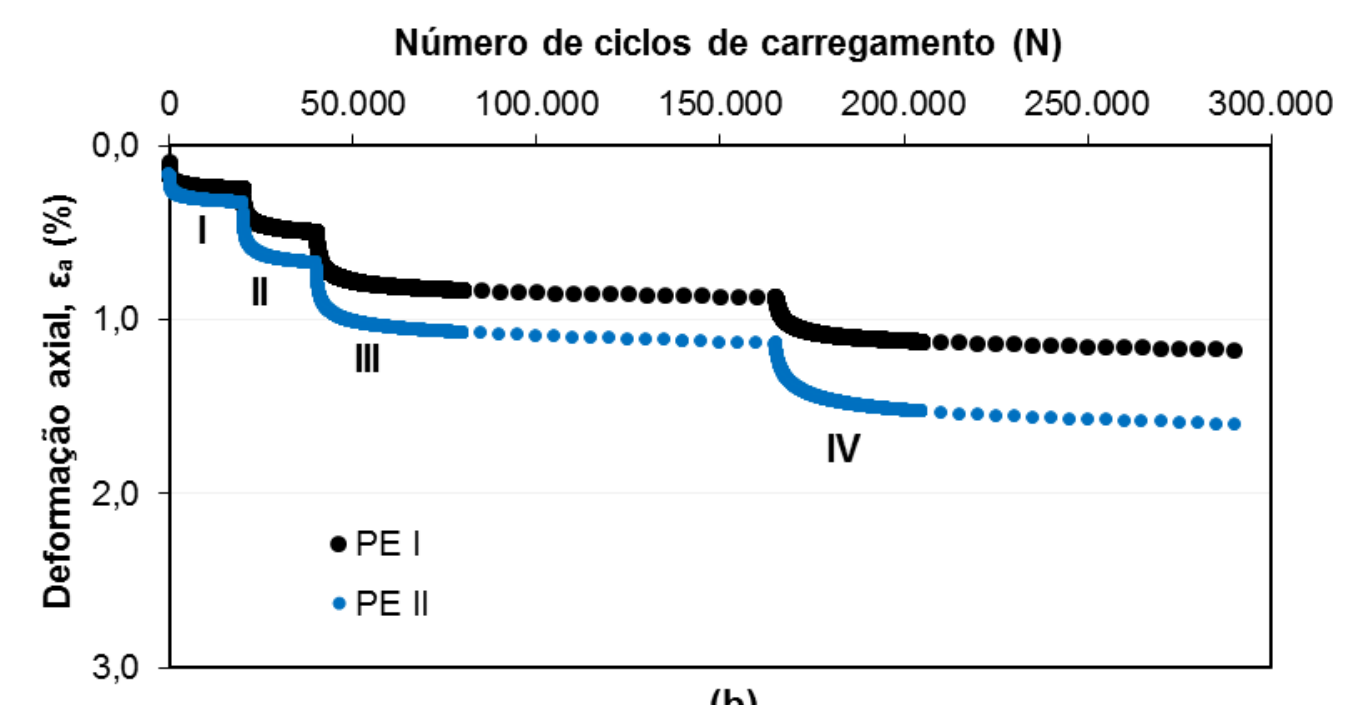

(b)

Figura 60 - Resultado dos ensaios PE I (AREMA 24) e PE II (AREMA 3) (a) módulo de resiliência (b) deformação permanente axial

Estes resultados revelam que as amostras de graduação uniforme (AREMA 3) apresentaram menor módulo de resiliência e maior deformação permanente axial. Por outro lado, pode-se notar que a graduação AREMA 24 gerou menor deformação axial permanente após 0 carregamento repetido. De acordo com Tutumluer et al. (2009), as granulometrias mais bem distribuídas, como AREMA 24, permitem melhor entrosamento dos agregados atingindo maior grau de compactação, apresentando, assim, maior resistência ao cisalhamento e menor deformação permanente. Quando graduação tende a ser mais uniforme, graduação AREMA 3, o lastro produz mais deformações plásticas sob carregamento (INDRARATNA et al., 2011). 
Para os quatro testes acima descritos, o carregamento de cada ensaio, tanto AREMA 3 como AREMA 24, foi dividido em quatro passos, no qual os corpos de prova foram submetidos a um total de 290.000 aplicações de carga (passos I e II, com 20,000 ciclos cada um, e as etapas III e IV, com 125.000 ciclos cada uma), como pôde ser visto nas Figuras 59 e 60. Os resultados de módulo de resiliência da etapa I para o ensaio PE I (AREMA 24) resultaram certa imprecisão, pois é justamente nesta fase de rearranjo em que acontecem as maiores deformações e estabilização da amostra, o que levou a problemas de captura dos dados relativos às deformações elásticas.

Ainda pelas Figuras 59 e 60 percebe-se que a relação entre a deformação permanente axial e o número de repetições de carga é bastante linear depois de certo número de aplicações de carga, dentro de todas as quatro fases, possuindo um comportamento assimptótico, após o período de rearranjo. De acordo com Selig e Waters (1994), a deformação permanente é caracterizada por um rápido aumento durante os primeiros ciclos, seguido de uma estabilização gradual, sendo que a quantidade de deformação depende das características do material e da carga aplicada.

Na sequência, estão apresentados os resultados para os testes PE V (AREMA 24) e PE VII (AREMA 3), tanto em escala linear como escala logarítmica (Figuras 61 e 62). Nestes dois ensaios, o modelo de carregamento aplicado foi baseado nas medidas de deslocamento realizadas na via permanente, fato já descrito anteriormente. A principal diferença para o modelo de Indraratna et al. 2010b, é que a tensão mínima aplicada durante todo o carregamento é a metade da tensão máxima, fazendo com que a amostra esteja sempre sob tensão, o que não permite a recuperação elástica total (usual para materiais a serem utilizados em pavimentos rodoviários) ou parcial (segundo modelo de carregamento de Indraratna et al. 2010b para lastros ferroviários). 


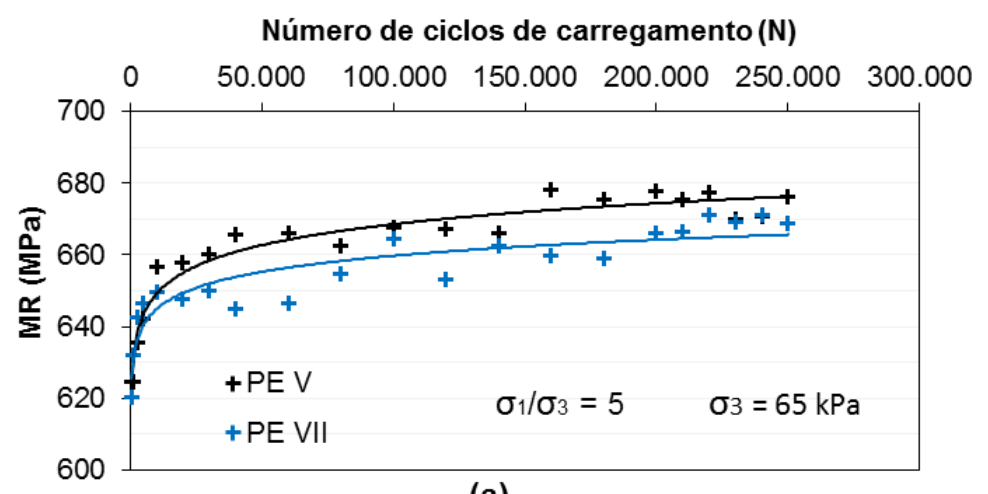

(a)

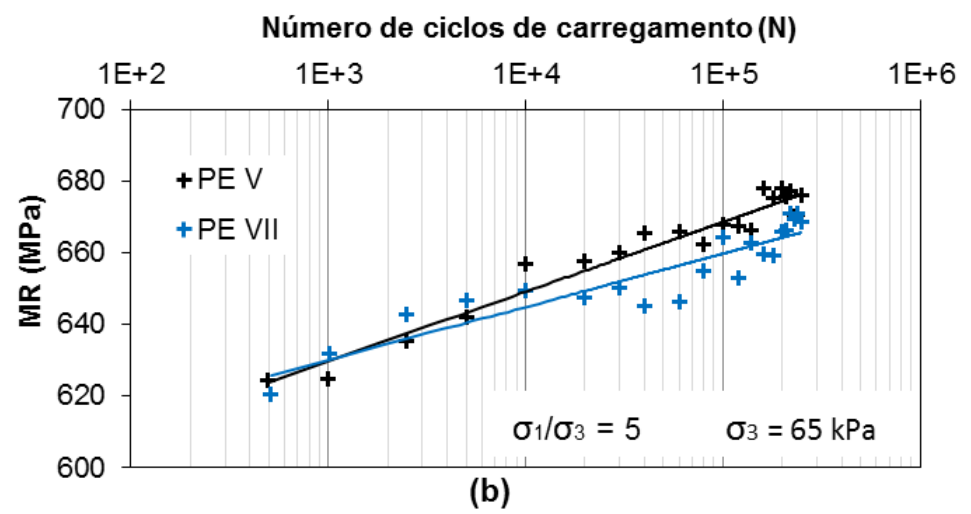

Figura 61 - Resultado dos ensaios PE V (AREMA 24) e PE VII (AREMA 3) de módulo de resiliência (a) escala linear (b) escala logarítmica
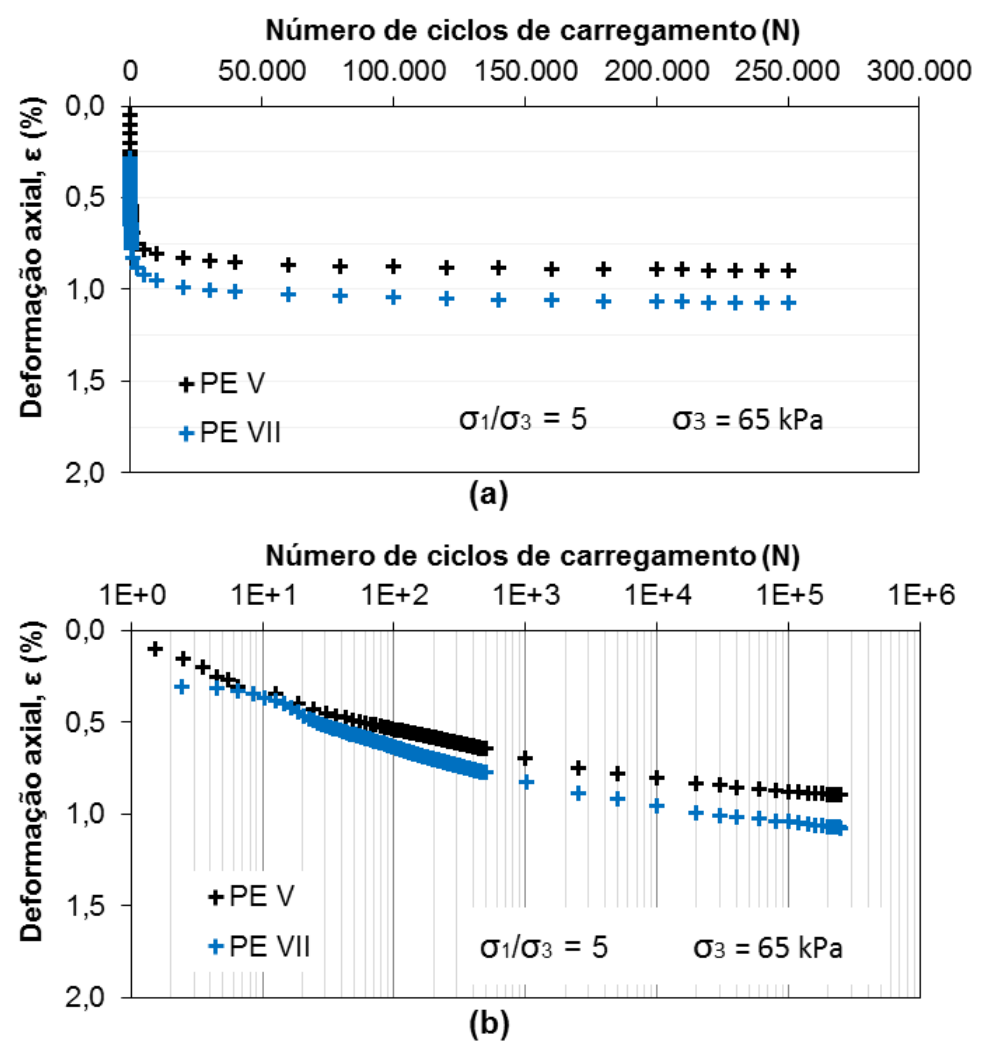

Figura 62 - Resultado de deformação permanente axial dos ensaios PE V (AREMA 24) e PE VII (AREMA 3) (a) escala linear (b) escala logaritmica 
Nos testes PE V e VII, o estado de tensão foi mantido constante durante toda a ciclagem, a fim de avaliar se o comportamento mecânico de ambas as graduações tinha o mesmo padrão encontrado nos testes anteriores. Percebeu-se um comportamento similar ao verificado nos outros testes, onde a graduação AREMA 24 apresentou melhor resposta mecânica.

É importante destacar o porquê dos elevados valores de módulo de resiliência que foram obtidos, cabendo mencionar que tais resultados já eram esperados, devido ao fato do material estar sempre em estado de tensão elevado. Simulando o que se ocorre em campo, não há descarregamento significativo entre a passagem dos eixos do trem, o que não permite que aconteçam deformações elásticas maiores, como no caso do outro modelo de carregamento aplicado descrito em Indraratna et al., 2010b.

Com relação aos resultados de deformação permanente, os valores encontram-se no mesmo nível dos outros ensaios, como por exemplo, PE VI e PE VIII que se utilizam do modelo de ciclo Indraratna et al. 2010b. Estes ensaios possuem a tensão máxima aplicada igual aos testes PE V e VII e, por isso, devem apresentar níveis de deformação permanente axial similar, devido ao fato deste tipo de material não depender da sequência de carregamentos aplicados, mas sim da tensão máxima imposta.

Os resultados para os testes PE VI (AREMA 24) e PE VIII (AREMA 3) estão apresentados na sequência, tanto em escala linear como escala logarítmica (Figuras 63 e 64). Nestes dois ensaios o modelo de ciclo aplicado foi baseado em Indraratna et al. 2010b, igual à maioria dos ensaios realizados nesta pesquisa. 


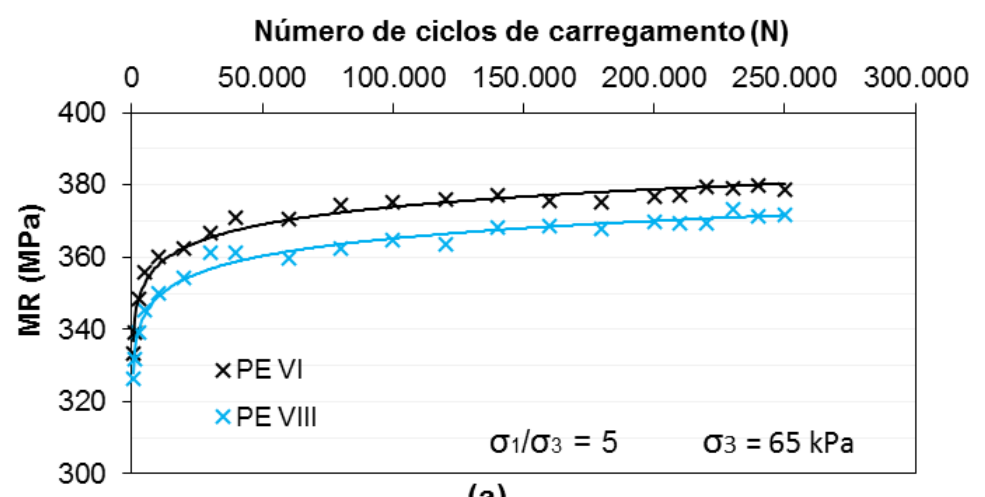

(a)

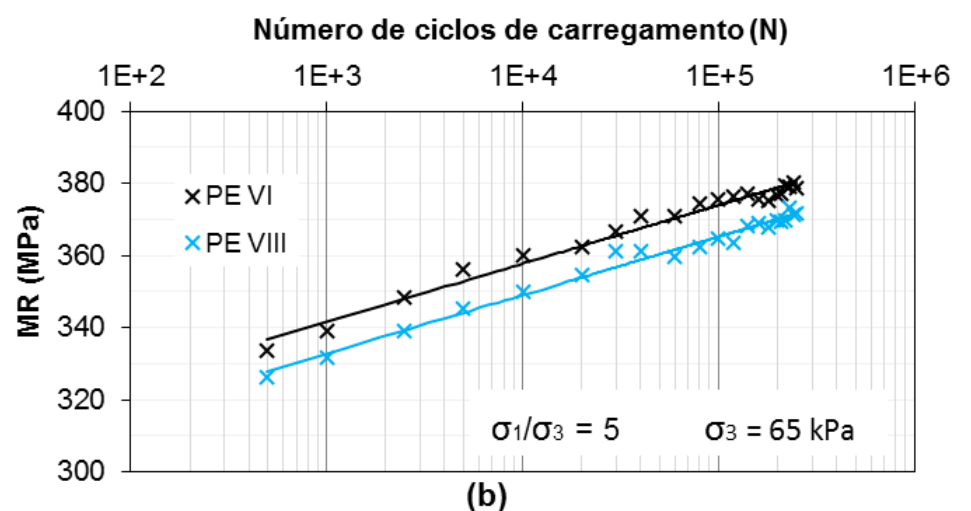

Figura 63 - Resultado dos ensaios PE VI (AREMA 24) e PE VIII (AREMA 3) de módulo de resiliência (a) escala linear (b) escala logarítmica
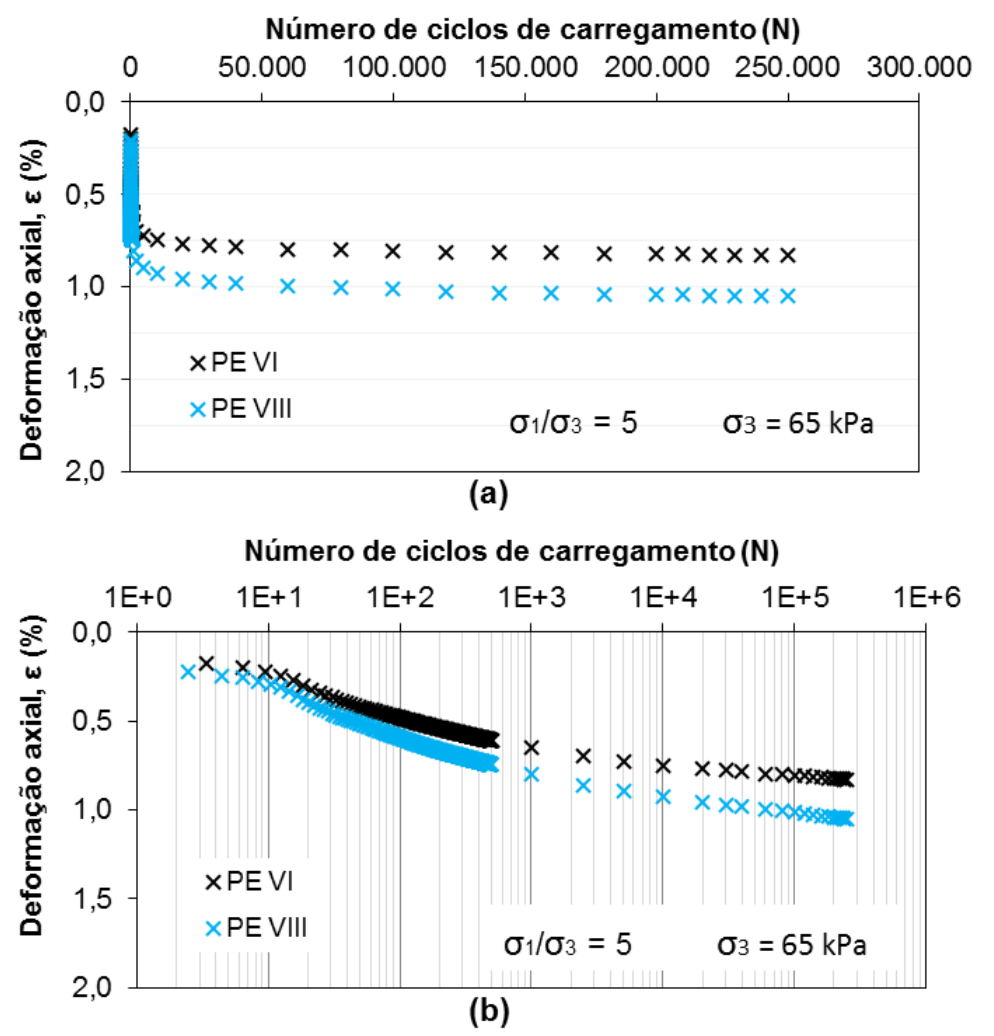

Figura 64 - Resultado de deformação permanente axial dos ensaios PE VI (AREMA 24) e PE VIII (AREMA 3) (a) escala linear (b) escala logarítmica 
Como indicado nas Figuras 63 e 64, os resultados para ambas as deformações elásticas e plásticas têm a mesma tendência, tal como apresentado nos testes anteriores (GE I, GE II, PE I e PE II). Não se variou o estado de tensão para estas duas amostras (PE VI e PE VIII), assim como nas amostras PE V e PE VII, a fim de avaliar se o comportamento mecânico de ambas as graduações seguiria a mesma tendência dos demais testes. Nota-se que AREMA 3 sempre apresenta uma maior taxa de deformação permanente axial e um menor valor do módulo de resiliência. Além disso, observou-se que os resultados obtidos para os ensaios PE VI e PE VIII foram semelhantes aos encontrados na etapa III, dos ensaios com as amostras PE I, PE II, PE IX e PE X, demonstrando que as respostas elásticas e plásticas do material não são dependentes da ordem de estado de tensão utilizado (crescente ou decrescente).

Por fim, os testes PE IX e PE $X$ foram submetidos ao ensaio de deformação permanente ao longo 160.000 ciclos, em cinco níveis de tensão desviadora diferentes (combinações I e II, com 20.000 ciclos cada um, e combinações III, IV e V, com 40.000 ciclos cada), cujos resultados estão apresentados na Figura 65. Na última combinação, que simula a via com carga de 40 t/eixo, foi alterada a tensão confinante de $65 \mathrm{kPa}$ para $50 \mathrm{kPa}$, a fim de se observar as mudanças nas deformações permanentes e resilientes das amostras. 


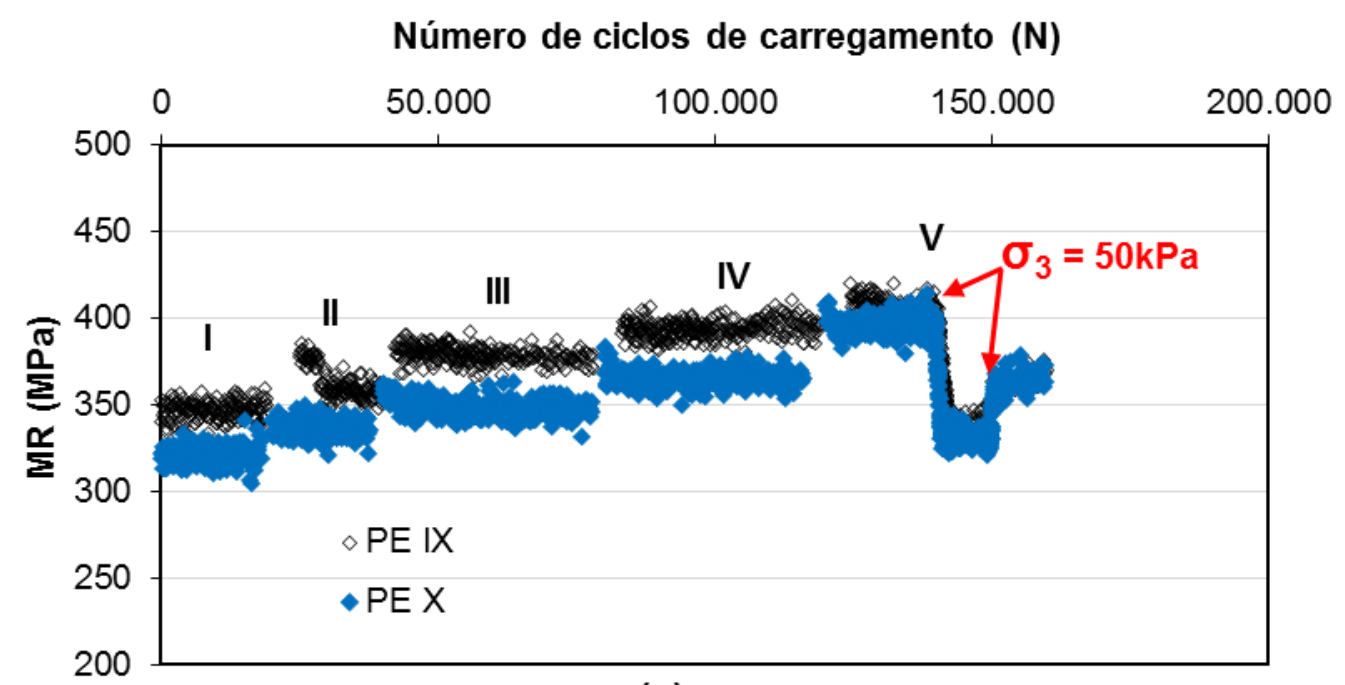

(a)

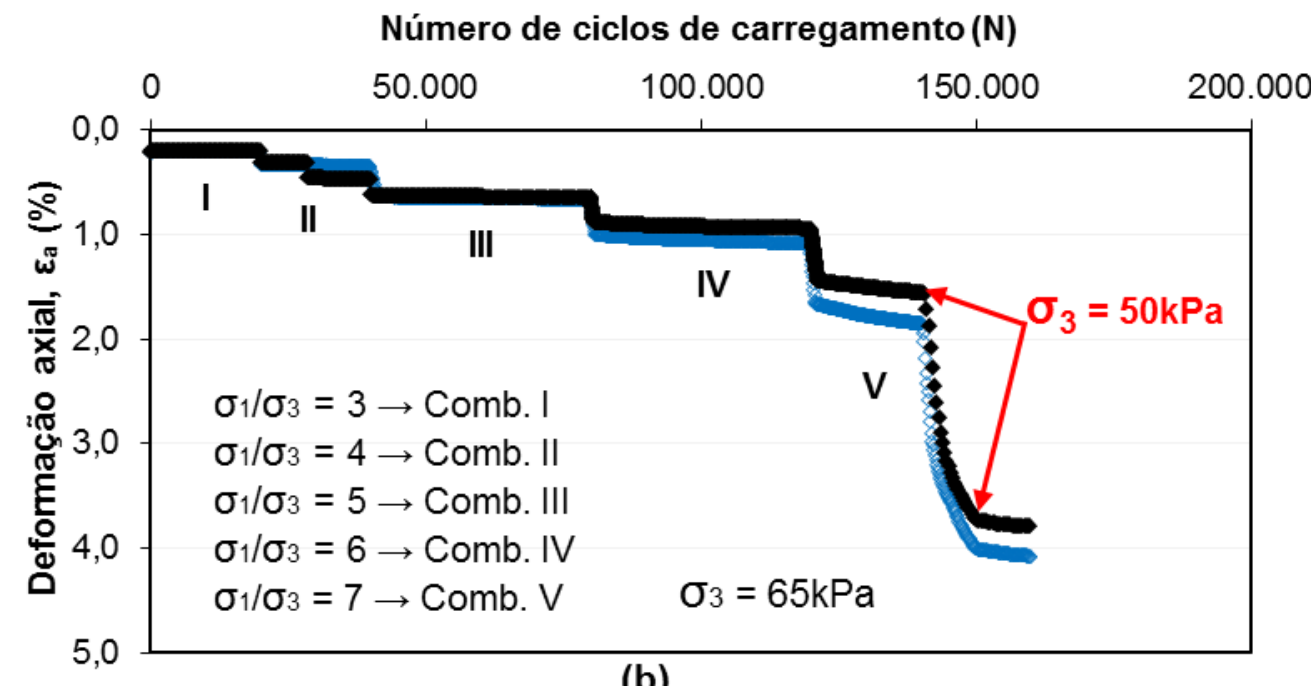

Figura 65 - Resultado dos ensaios PE IX (AREMA 24) e PE X (AREMA 3) (a) módulo de resiliência (b) deformação permanente axial

A Figura 65 mostra que a taxa de deformação permanente axial medida em cada combinação aumenta, a partir da etapa I, para ambas as graduações AREMA 3 e AREMA 24. No entanto, os resultados para AREMA 3 evidenciam maior taxa de deformação permanente axial em comparação à amostra de graduação AREMA 24 (PE IX). Tal comportamento demonstra que uma mudança granulométrica para uma curva mais bem distribuída pode levar à vantagem de se ter uma deformação permanente axial menor. Nota-se que na última etapa (entre ciclos de carga de 140.000 e 150.000) houve mudanças significativas em relação módulo de resiliência e deformações permanentes axiais devido à redução intencional da tensão confinante, de 65 a $50 \mathrm{kPa}$, imposta à amostra. Estes resultados experimentais 
mostraram que a deformação permanente é maior quando ocorre um aumento da tensão-desvio $\left(\sigma_{d}\right)$ ou redução da tensão confinante $\left(\sigma_{3}\right)$, assim, verifica-se que valores maiores de confinamento são benéficos para minimizar as deformações permanentes e resilientes do material de lastro. Se uma melhora no que diz respeito ao aumento da tensão confinante for implementada in situ, o comportamento das vias férreas com lastro pode ser melhorado em termos de degradação, resistência à deformação e resiliência (INDRARATNA et al., 2011).

As Figuras 66 a 70 exibem os resultados dos ensaios de granulometria realizados para cada amostra, antes e após o carregamento. Os resultados indicam que a quebra dos agregados do lastro e o consequente aparecimento de finos diminui com - aumento de $C_{u}$ (coeficiente de uniformidade), como observado por Indraratna et al. (2004). Além disso, em termos de deformação e resistência à quebra dos agregados, a graduação AREMA 24 se comporta melhor em comparação à graduação AREMA 3, devido ao arranjo do conjunto de agregados antes do carregamento cíclico (INDRARATNA et al., 2004). Tal degradação tende a ser mais elevada à medida que o número de ciclos de carga aumenta, levando a menores tamanhos de agregados e valores de angularidade e, por conseguinte, a resistência ao cisalhamento e a capacidade de drenagem da camada de lastro diminuem (INDRARATNA et al., 2011).

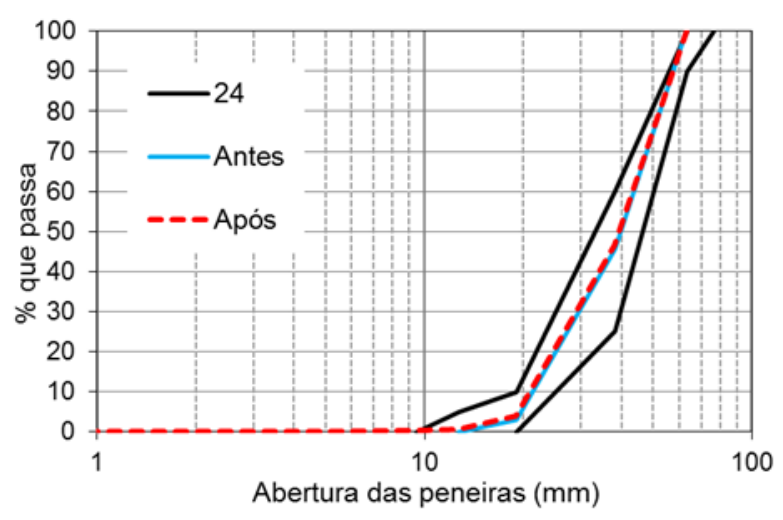

(a)

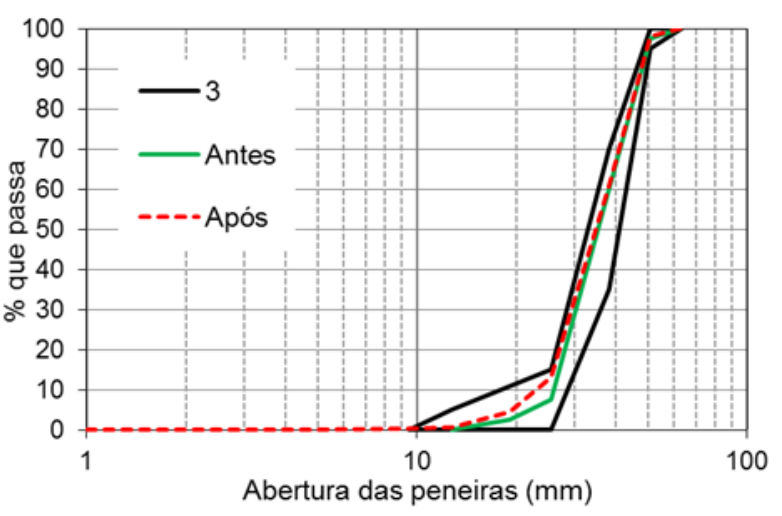

(b)

Figura 66 - Distribuições granulométricas das amostras GE I e GE II 


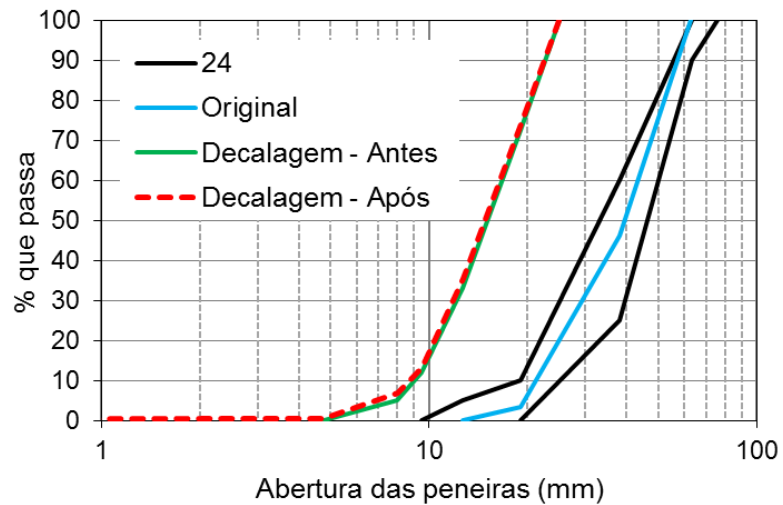

(a)

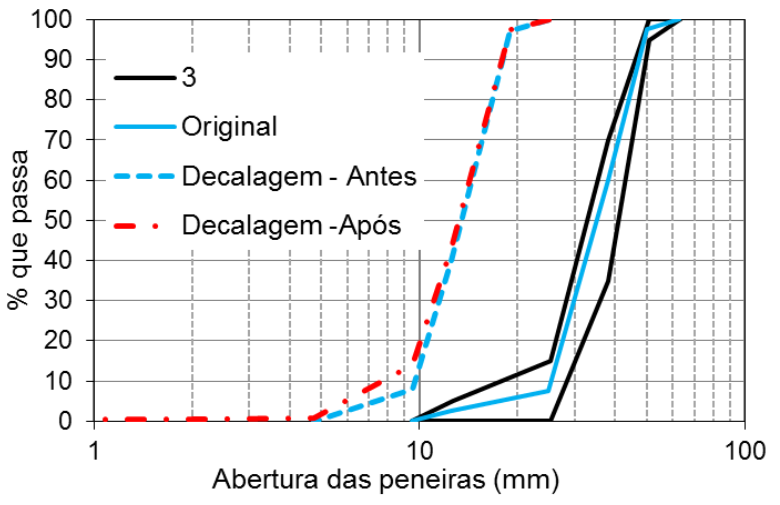

(b)

Figura 67 - Distribuições granulométricas das amostras PE I e PE II

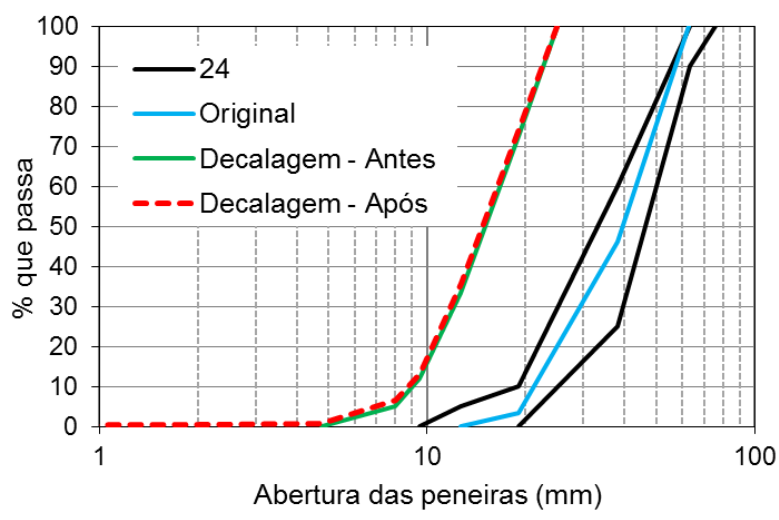

(a)

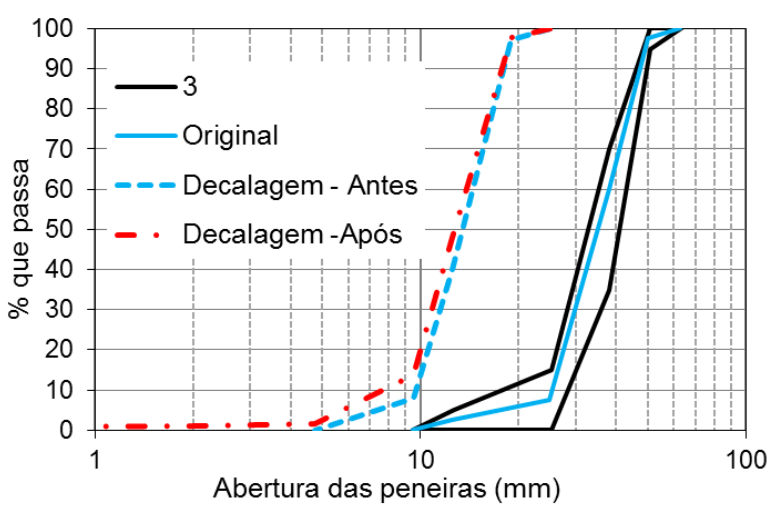

(b)

Figura 68 - Distribuições granulométricas das amostras PE V e PE VII

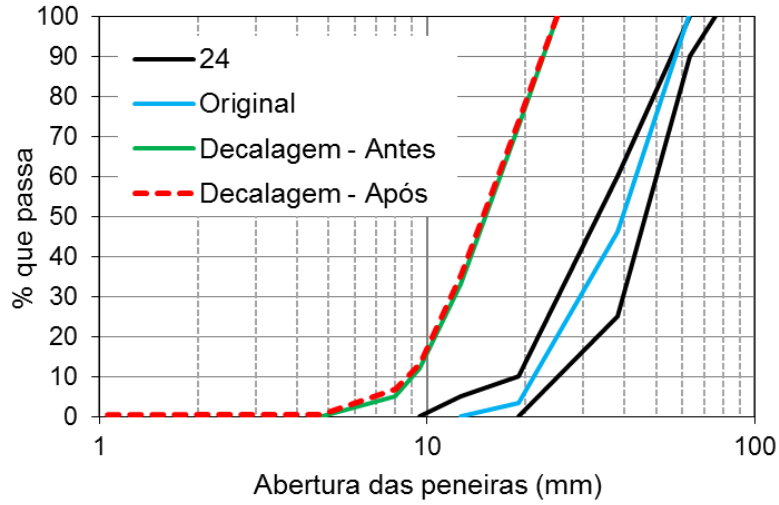

(a)

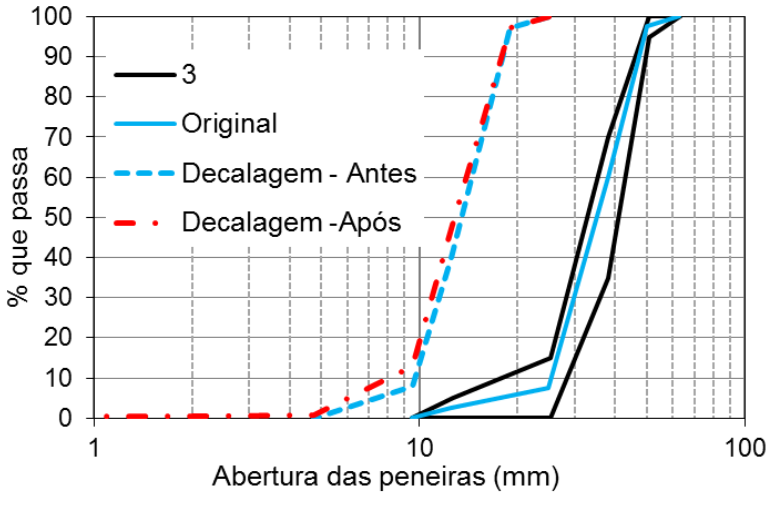

(b)

Figura 69 - Distribuições granulométricas das amostras PE VI e PE VIII 


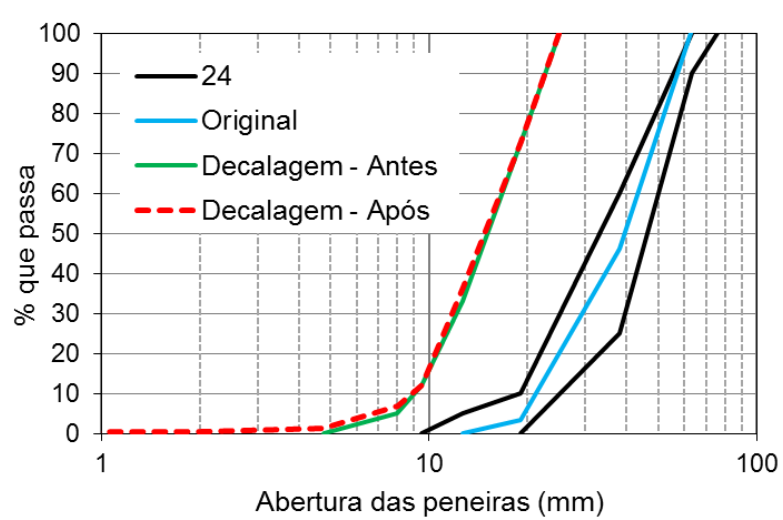

(a)

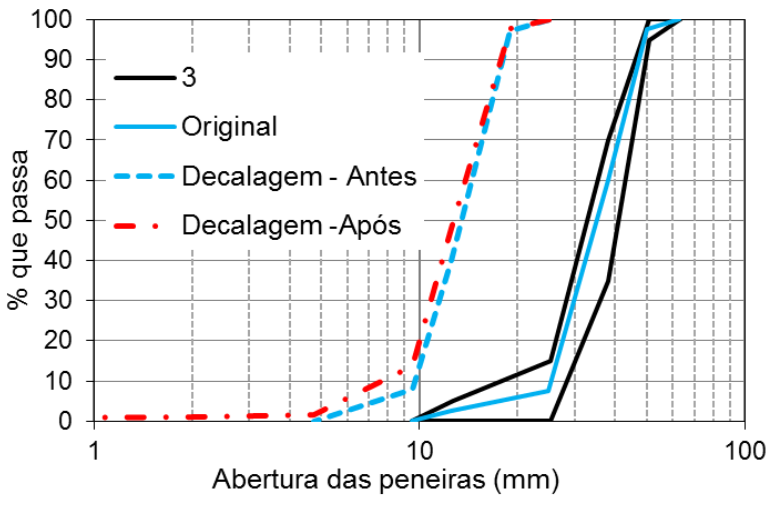

(b)

Figura 70 - Distribuições granulométricas das amostras PE IX e PE X

De acordo com Selig e Waters (1994) e Tutumluer et al. (2006), a distribuição granulométrica tem papel importante no comportamento do sistema, uma vez que tem influência direta nas forças de contato entre os agregados que, devido às solicitações, podem alterar a estrutura do lastro, com rearranjo dos mesmos. Em suma, estes movimentos ocasionados pelas solicitações são resistidos por forças de atrito entre os agregados, estando diretamente ligados às deformações. Curvas bem graduadas proporcionam melhor intertravamento dos agregados e composições mais densas (maior estado de compactação), levando à menor deformação. Entretanto, por outro lado, quase todas as especificações de lastro exigem graduações uniformes, a fim de permitir a drenagem livre. Dentro deste contexto, Indraratna et al. (2011) apontam que deve existir uma determinada graduação de lastro que garanta adequada estabilidade, sem causar significativo comprometimento à drenagem. 


\subsubsection{Influência do carregamento}

Esta análise compreendeu a comparação de quatro amostras divididas em pares. Cada par está composto por amostras de mesma granulometria e tipos de carregamento distintos. Dois tipos de carregamento foram adotados com intuito de entender possíveis alterações no comportamento do material ao longo da ciclagem. Foi ainda utilizado um modelo de ciclo harmônico de carregamento baseado em Indraratna et al. (2010b), que tem como tensão mínima $\left(q_{\text {mín }}\right) 45 \mathrm{kPa}$ (devido ao peso próprio da superestrutura), a qual é uma tensão que representa um estado de via descarregada, além de um outro tipo de carregamento, por sua vez, com tensão mínima $\left(q_{\text {minn }}\right)$ que corresponde à metade da tensão máxima aplicada $\left(q_{\text {máx }}\right)$. Este $q_{\text {min }}$ utilizado se baseou em medidas de deslocamentos registrados em campo pelo LTP. Por fim, foi realizado um ensaio de módulo de resiliência com o objetivo de analisar os efeitos da mudança de carregamento no comportamento elástico do material. A Tabela 13 resume os detalhes dos corpos de prova para esta análise.

Tabela 13 - Detalhes dos ensaios para o estudo da influência do carregamento

\begin{tabular}{|c|c|c|c|c|c|c|c|c|c|}
\hline Amostra & $\begin{array}{c}\text { Dimensão } \\
(\mathbf{m m})\end{array}$ & $\begin{array}{c}\text { Graduação } \\
\text { (AREMA) }\end{array}$ & Material & $\begin{array}{c}\text { Massa } \\
(\mathbf{k g})\end{array}$ & $\begin{array}{c}\boldsymbol{\gamma} \boldsymbol{n} \\
\left(\mathbf{g} / \mathbf{c m}^{3}\right)\end{array}$ & $\boldsymbol{e}$ & $\boldsymbol{n}$ & $\boldsymbol{C u}$ & $\boldsymbol{c} \boldsymbol{c}$ \\
\hline PE V & $150 \times 300$ & 24 & limpo & 8,52 & 1,61 & 0,74 & 0,43 & 1,99 & 0,98 \\
\hline PE VI & $150 \times 300$ & 24 & limpo & 8,51 & 1,61 & 0,74 & 0,43 & 1,98 & 0,98 \\
\hline PE VII & $150 \times 300$ & 3 & limpo & 8,45 & 1,59 & 0,76 & 0,43 & 1,60 & 0,97 \\
\hline PE VIII & $150 \times 300$ & 3 & limpo & 8,44 & 1,59 & 0,76 & 0,43 & 1,59 & 0,98 \\
\hline PE XI & $150 \times 300$ & 24 & limpo & 8,52 & 1,61 & 0,74 & 0,43 & 1,96 & 1,00 \\
\hline
\end{tabular}

Os ensaios PE V e PE VI, ambos de graduação AREMA 24, já foram descritos anteriormente (sempre com tensão confinante de $65 \mathrm{kPa}$ e uma única razão entre a tensão principal maior e a confinante, igual a 5). Tal fato também se estende à próxima comparação, entre os ensaios PE VII e PE VIII de graduação AREMA 3. O propósito desta análise é evidenciar possíveis diferenças de comportamento do material relativas à mudança no estado de tensão, que é reflexo da variação do carregamento ocasionada pela alteração das condições estruturais da via, juntamente com o efeito dinâmico da passagem dos trens. As Figuras 71 e 72 apresentam os valores de MR e as Figuras 73 e 74 os valores de deformação permanente axial, tanto em escala linear como logarítmica, respectivamente. 


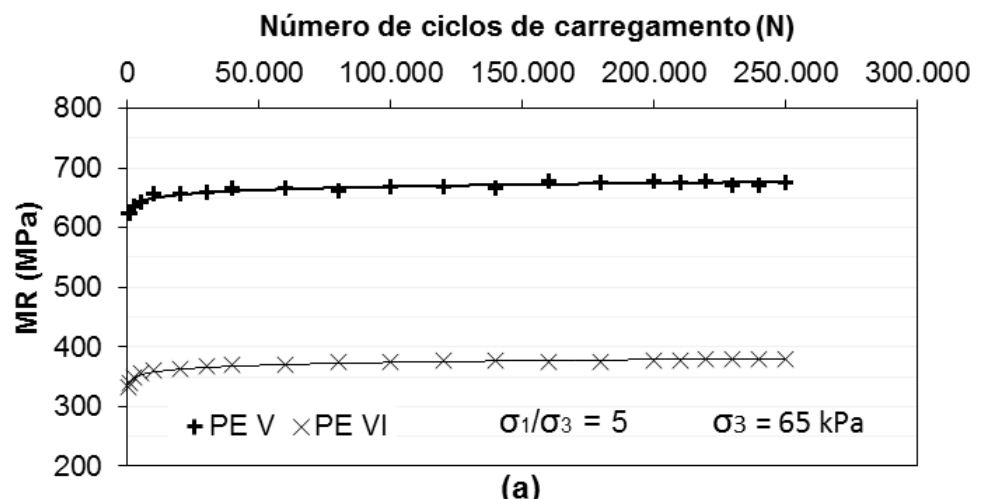

(a)

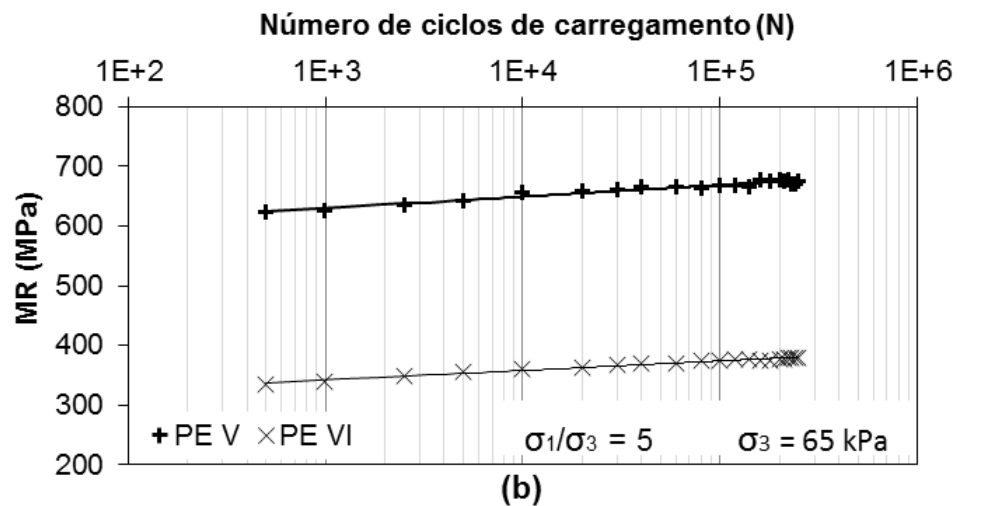

Figura 71 - Resultado dos ensaios PE V (AREMA 24) e PE VI (AREMA 24) de módulo de resiliência (a) escala linear (b) escala logarítmica

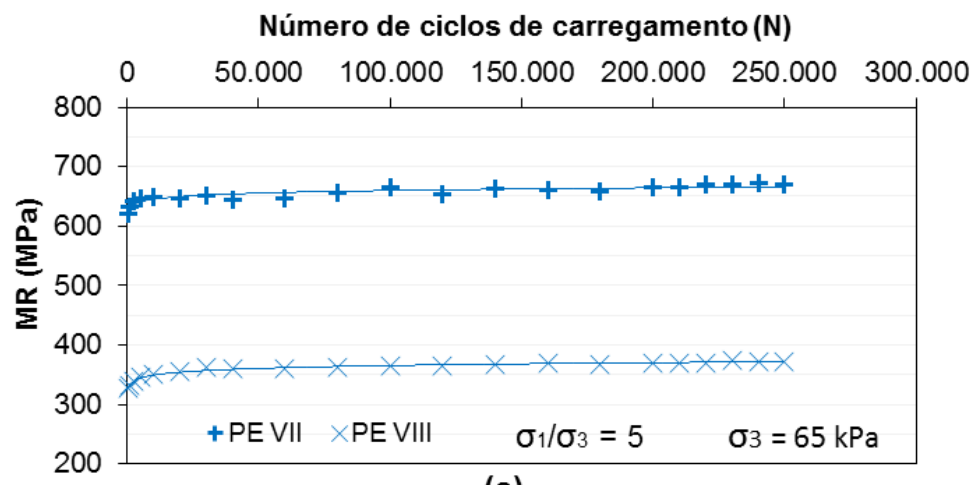

(a)

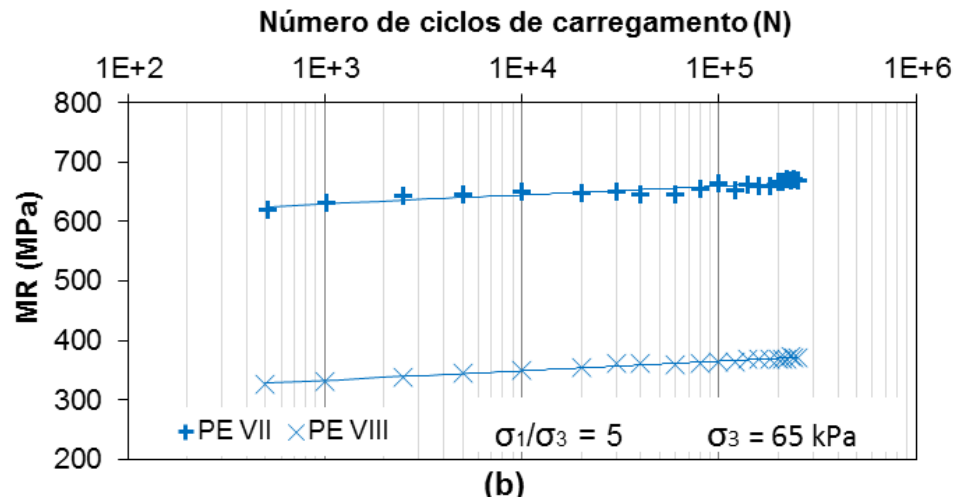

Figura 72 - Resultado dos ensaios PE VII (AREMA 3) e PE VIII (AREMA 3) de módulo de resiliência (a) escala linear (b) escala logarítmica 

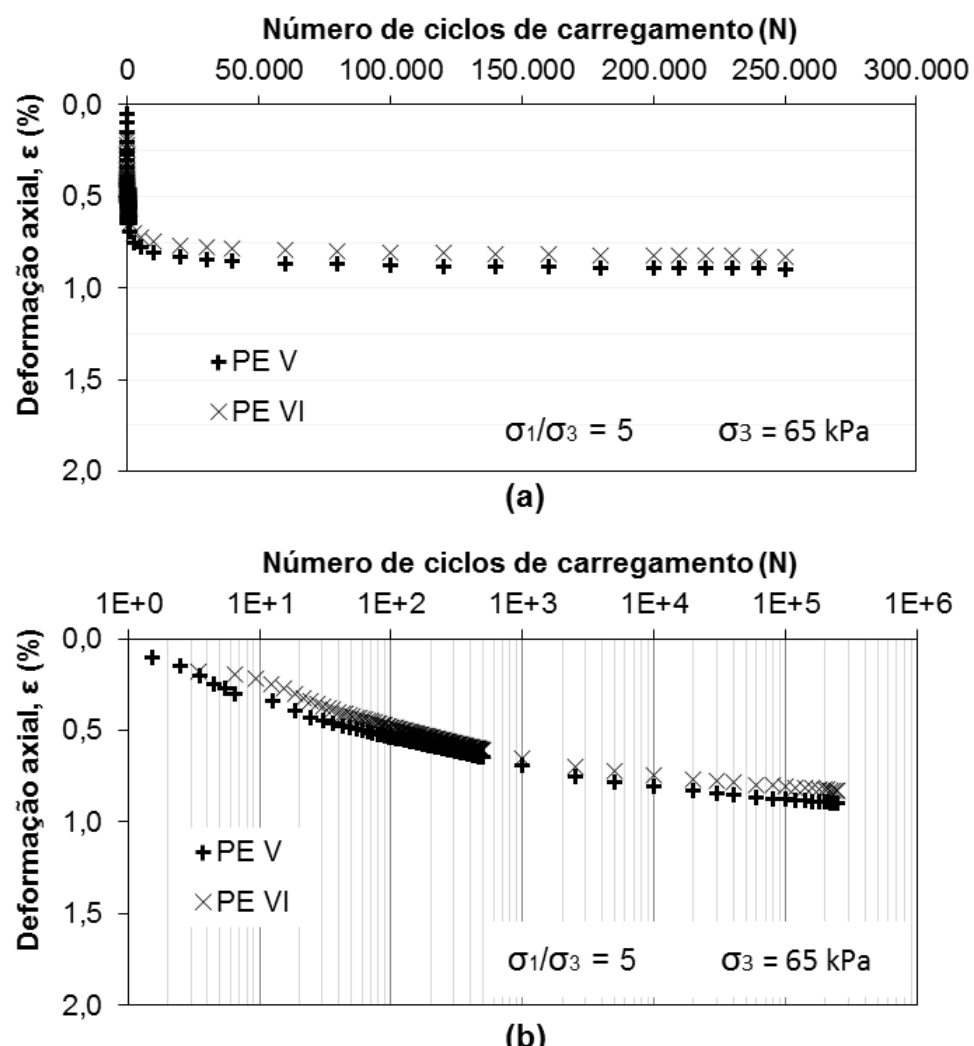

(b)

Figura 73 - Resultado de deformação permanente axial dos ensaios PE V (AREMA 24) e PE VI (AREMA 24) (a) escala linear (b) escala logarítmica

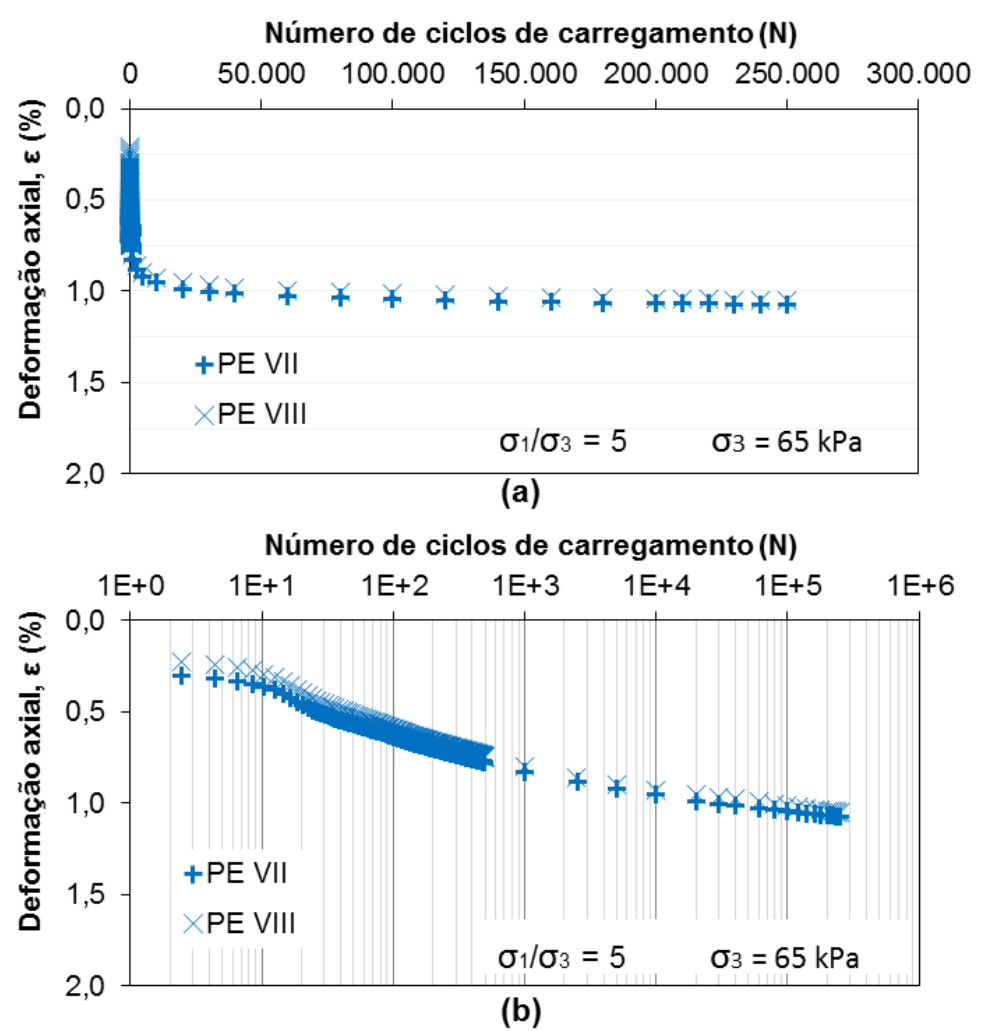

Figura 74 - Resultado de deformação permanente axial dos ensaios PE VII (AREMA 3) e PE VIII (AREMA 3) (a) escala linear (b) escala logarítmica 
Nas amostras PE V e PE VII, foi empregada a situação de carregamento tal qual medida em campo pelo LTP, enquanto que com as amostras PE VI e PE VIII fez-se uso do modelo adotado por Indraratna et al. (2010b). A diferença entre as duas condições de carregamento claramente evidenciam a mudança quanto ao comportamento das deformações elásticas, tanto para os corpos de prova de graduação AREMA 24 quanto AREMA 3. Em todos os casos, os corpos de prova que tiveram a ciclagem baseada no modelo medido pelo LTP resultaram em MR superiores, uma vez que este modelo de carregamento expõe o material a um estado de tensão que não permite alívio de carga e, assim, as deformações elásticas são limitadas pela tensão residual (que, neste caso, é a metade da tensão máxima aplicada). Contrariamente, as amostras que tiveram o carregamento fundamentado em Indraratna et al. (2010b) tiveram maiores deformações elásticas e menores valores de MR, pois a tensão residual neste modelo é mais baixa (45 kPa).

Com relação às deformações específicas axiais permanentes, o fato destas não dependerem da sequência de carregamento, mas sim da tensão máxima aplicada, faz com que o resultado entre os ensaios de mesma granulometria tenham valores similares, como observou-se nos ensaios PE V e PE VI, em torno de 0,8\%, e nos ensaios PE VII e PE VIII, chegando a 1,1\% de deformação específica axial permanente.

Pelas medições realizadas in situ pelo LTP, percebeu-se que no momento da passagem do trem a via permanente é carregada de forma que as deformações se situavam em um nível diferente do modelo de Indratana et al. 2010b (com tensão residual além do valor do peso próprio da superestrutura). Desta forma, o estado de tensão ao qual o material é submetido é alterado, o que muda o comportamento mecânico e as respostas das deformações elásticas. Vale ressaltar que o modelo de carregamento proposto pelas medidas de campo foi obtido com base em deformações, portanto uma resposta secundária, haja vista que tais deformações são geradas a partir da atuação da carga pela passagem do trem.

Durante a passagem de um mesmo trem as respostas deformacionais dos materiais da subestrutura, principalmente do lastro, alteram-se até o momento em que ocorre uma certa estabilização, quando as deformações entram em um nível constante. Esta transição no comportamento mecânico é reflexo direto da variação do estado 
de tensão, que é um efeito complexo devido à interação e à natureza dos componentes. A proposta de se utilizar um modelo de carregamento baseado em medidas de campo serve apenas como um primeiro passo para se entender a variabilidade de comportamento dos materiais geotécnicos da subestrutura ferroviária.

O estado de tensão no lastro decorre das condições de cada local da via permanente, portanto a resposta às deformações pode diferir de um ponto para outro. Com isto, as diferentes condições da subestrutura alteram as repostas mecânicas e, assim, a interação entre os componentes, situação similar à variação não linear do módulo de via, fato já citado por Muniz (2002). Entretanto, é importante realizar mais medições in situ, tanto de deformações quanto de tensões e, desta forma, se chegar ao modelo de carregamento similar à condição de uma determinada ferrovia.

O importante é minimizar o efeito da alteração brusca do estado de tensões que acontece a cada nova passagem de trens. É próprio deste tipo de estrutura que aconteça uma rápida variação entre as relações de tensões, porém deve-se garantir maior homogeneidade e estabilidade da camada de lastro a fim de que a mesma possua confinamento satisfatório para suportar as variações de tensão devido ao carregamento dinâmico. Uma disparidade muito grande entre uma situação descarregada e uma carregada causará desgaste intenso de todos os componentes, reduzindo a vida útil da estrutura.

As Figuras 75 e 76 exibem os resultados dos ensaios de granulometria realizados para cada amostra, antes e após o carregamento. Estes indicam que, assim como todos os outros ensaios já mencionados, houve quebra dos agregados do lastro, e o consequente aparecimento de finos. Entretanto, a mudança das condições de carregamento não gerou alteração quando se comparam composições granulométricas iguais, devido ao mesmo fato já mencionado no caso das deformações permanentes. 


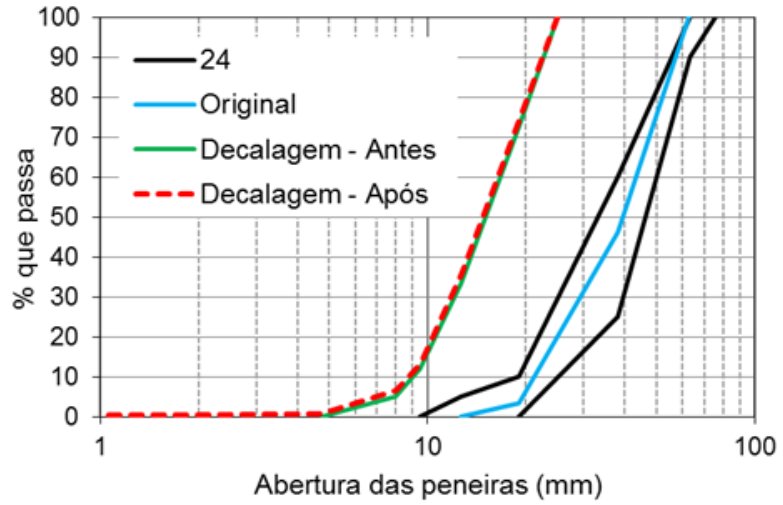

(a)

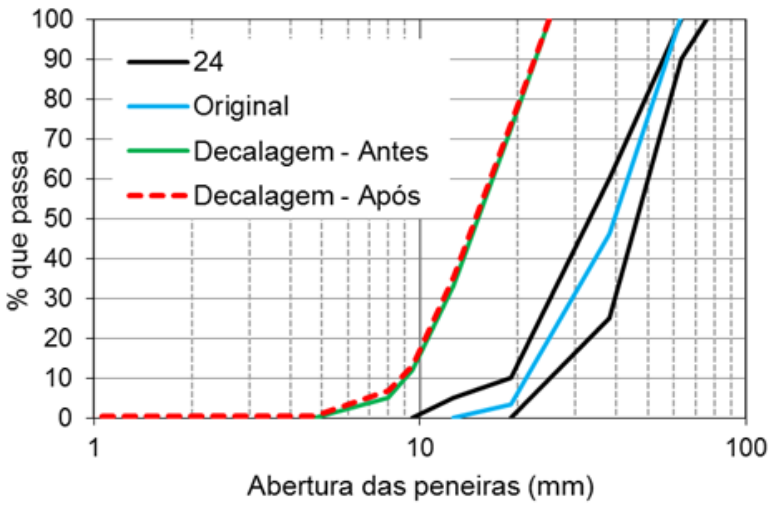

(b)

Figura 75 - Distribuições granulométricas das amostras PE V e PE VI

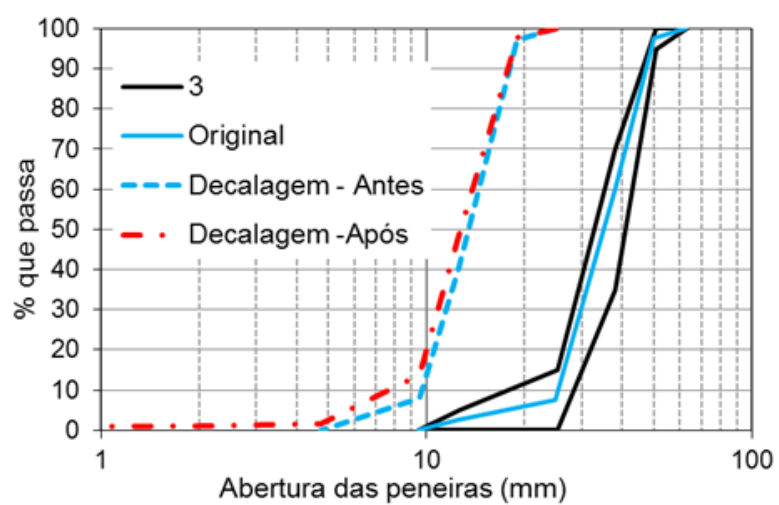

(a)

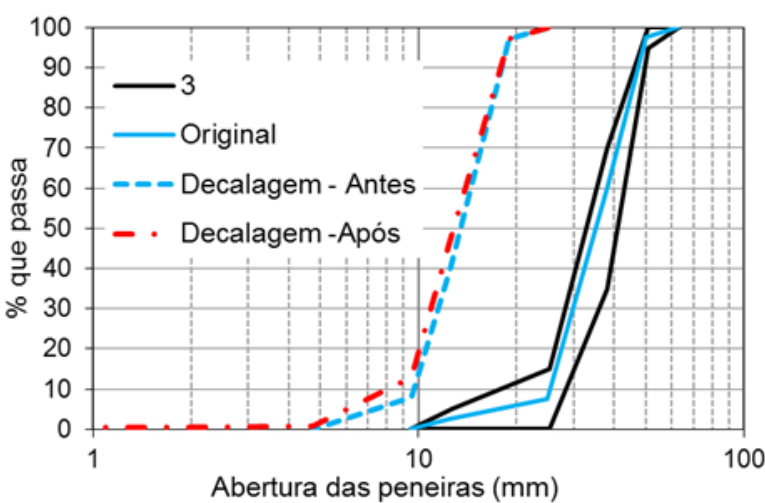

(b)

Figura 76 - Distribuições granulométricas das amostras PE VII e PE VIII

O ensaio de módulo de resiliência (amostra PE XI) foi elaborado de maneira a tentar não comprometer a estrutura da amostra durante a ciclagem, já que um único corpo de prova foi utilizado para diferentes estados de tensão, seguindo procedimento normalmente adotado para ensaios de resiliência.

A tensão $\sigma_{3}$ foi mantida constante para três valores de $\sigma_{d}$, com razões $\sigma_{d} / \sigma_{3}$ iguais a 0,5, 1,2 e 1,8 durante cada uma das cinco séries. Desta maneira a amostra é menos perturbada pelas tensões anteriormente aplicadas, já que o ângulo de atrito no qual o material está sendo solicitado é mantido distante do ângulo de atrito máximo do material. Vale ressaltar que não foram realizados ensaios monotônicos neste material para se encontrar o valor de ângulo atrito de pico, entretanto, buscou-se em Suiker et al. (2005), Sousa Pinto (2000) e Lambe e Whitman (1969) um valor de 
referência com material similar ao adotado nos ensaios, tendo sido considerado $46^{\circ}$ (Figura 77).

Neste ensaio, o objetivo é analisar a ação tanto da tensão confinante como da tensão desviadora e de entender a influência de dois tipos de carregamento. Para tanto, foi levado em conta um tipo de carregamento sem tensão residual, ou seja, similar aos ensaios para pavimento rodoviário (carregamento 1) e outro similar ao modelo de carregamento medido na EFVM (carregamento 2). Neste ensaio, o modelo de carregamento de Indraratna et al. 2010b não foi considerado, pois pretendia-se entender a variação das deformações elásticas entre dois extremos: uma situação sem nenhuma tensão de contato e outra com a metade da tensão máxima aplicada.

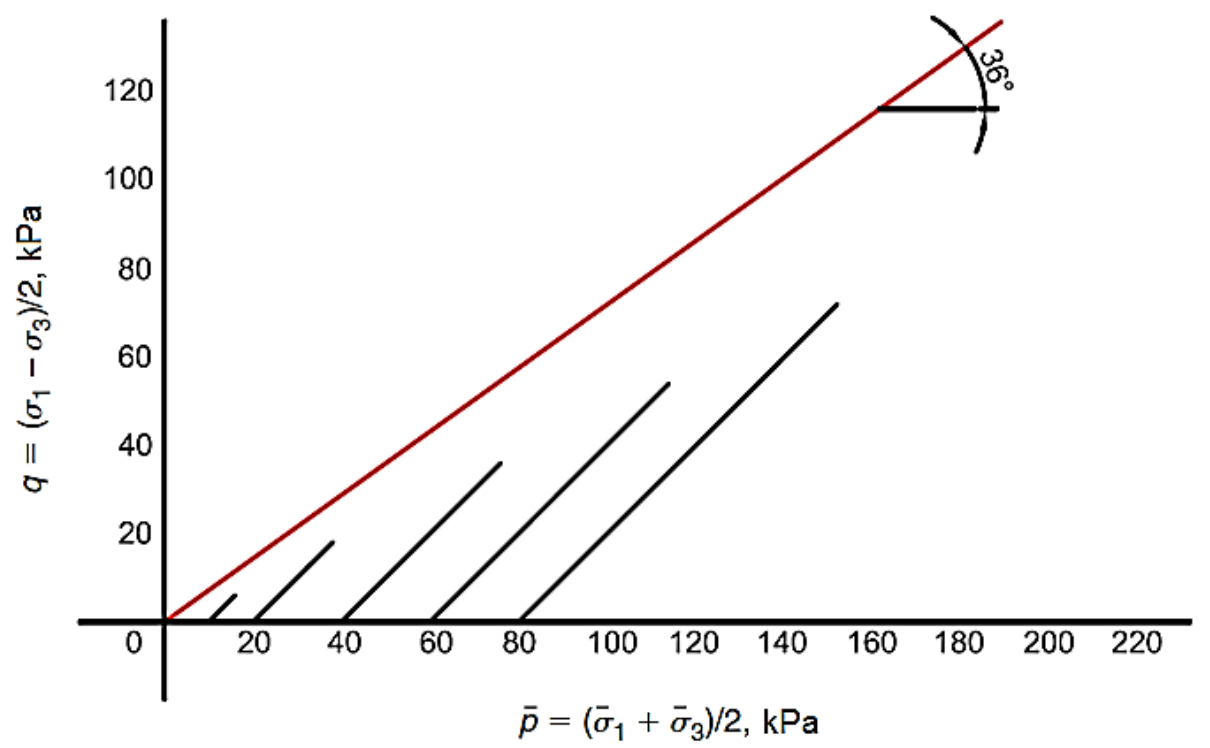

Figura 77 - Envoltória às trajetórias de tensão

As séries de tensões confinantes foram aplicadas em ordem decrescente, para se evitar que ocorressem deformações permanentes elevadas, o que levaria a um rearranjo dos agregados e, assim, a resposta resiliente poderia não corresponder ao arranjo inicial do material (Tabela 14). 
Tabela 14 - Combinações de tensões aplicadas no ensaio de módulo de resiliência

\begin{tabular}{|c|c|c|c|}
\hline Série & $\sigma_{3}(\mathrm{kPa})$ & $\sigma_{d}(k P a)$ & $\sigma_{3} / \sigma_{d}$ \\
\hline \multirow{3}{*}{1} & \multirow{3}{*}{80} & 40 & 0,5 \\
\hline & & 96 & 1,2 \\
\hline & & 144 & 1,8 \\
\hline \multirow{3}{*}{2} & \multirow{3}{*}{60} & 30 & 0,5 \\
\hline & & 72 & 1,2 \\
\hline & & 108 & 1,8 \\
\hline \multirow{3}{*}{3} & \multirow{3}{*}{40} & 20 & 0,5 \\
\hline & & 48 & 1,2 \\
\hline & & 72 & 1,8 \\
\hline \multirow{3}{*}{4} & \multirow{3}{*}{20} & 10 & 0,5 \\
\hline & & 24 & 1,2 \\
\hline & & 36 & 1,8 \\
\hline \multirow{3}{*}{5} & \multirow{3}{*}{10} & 5 & 0,5 \\
\hline & & 12 & 1,2 \\
\hline & & 18 & 1,8 \\
\hline
\end{tabular}

Nas Figuras 78 e 79 os valores de MR estão dispostos em relação à tensão de confinamento e desviadora, respectivamente. Ressalta-se que, ao final do ensaio, a deformação específica axial permanente máxima foi inferior a 0,2\%, caracterizando que o carregamento aplicado não alterou significativamente a estrutura da amostra, situação que poderia comprometer os resultados. 


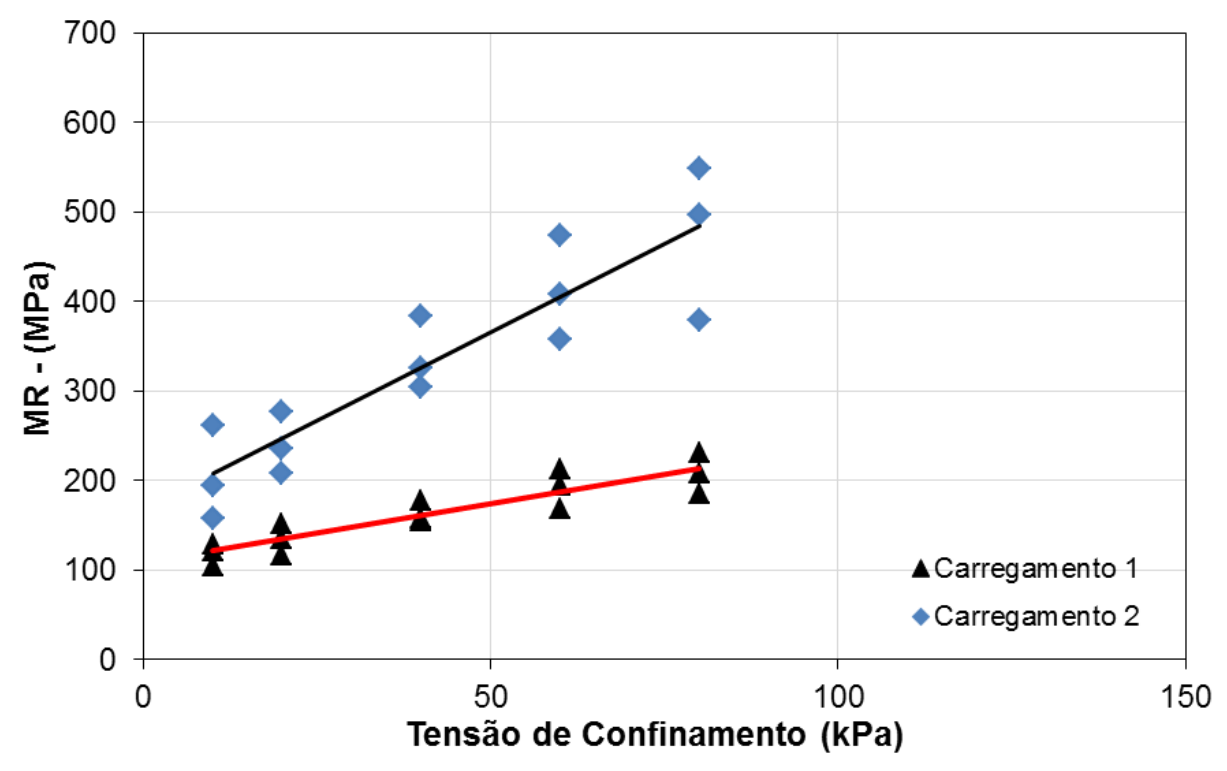

Figura 78 - Módulo de resiliência versus tensão confinante

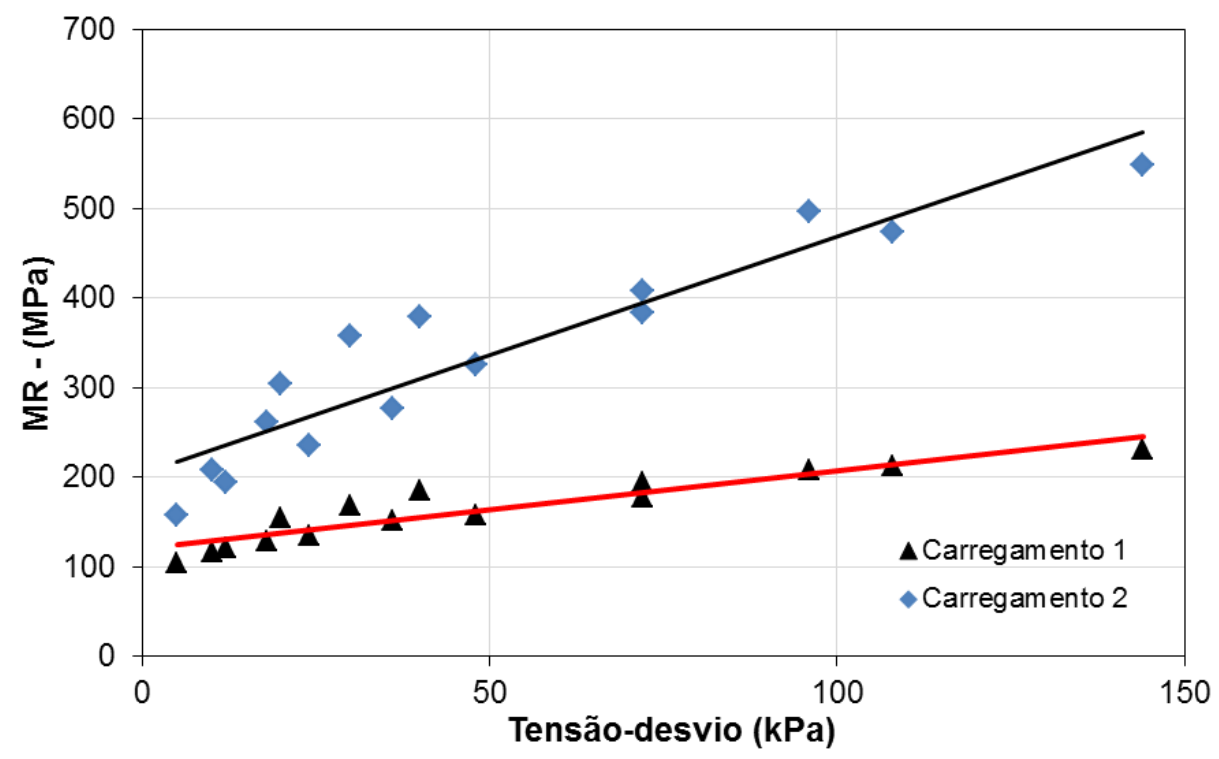

Figura 79 - Módulo de resiliência versus tensão-desvio

Assim como nos corpos de prova deste mesmo item, mostrados anteriormente, o carregamento que possui tensão residual resultou em valores de MR superiores aqueles que não tiveram tensão de contato. Além disto, ficou evidenciada a influência tanto da tensão confinante como da tensão-desvio para a rigidez do material. Os resultados demonstrados pelo lastro são próprios de um material granular e, portanto, de comportamento elasto-plástico. Para este tipo de material, a 
deformação resiliente axial depende consideravelmente da tensão confinante aplicada, Figura 78.

O efeito do aumento da tensão-desvio também é notado, como indicado pela Figura 79, porém em menor proporção. Segundo Alva-Hurtado (1980), a magnitude da tensão-desvio aplicada é um fator importante para alteração do comportamento elástico, pois quando se aplica tensões desviadoras próximas à tensão de ruptura do material, são obtidos elevados valores de módulo de resiliência.

Com relação à alteração do estado de tensão devido à reação dinâmica da passagem dos trens, existe uma dependência da interação entre os componentes para a resposta mecânica. A relação do carregamento com a deformação é não linear, assim o valor do módulo de via depende do nível de carregamento (SPADA, 2003). O projeto de uma via férrea com subestrutura resiliente deve passar pelo entendimento da magnitude das cargas que serão impostas sobre a estrutura durante a vida útil e das alterações inerentes ao desgaste dos componentes. As cargas impostas pela passagem dos trens aos trilhos geram uma complexa reação de cargas estáticas e dinâmicas. A carga estática é composta pelo peso do trem e da superestrutura, enquanto que o componente dinâmico é função das condições de via, características do trem e condições de operação. É o componente dinâmico que normalmente provoca um efeito adverso para a via, uma vez que pode ser muito maior do que a carga estática.

Na Figura 80 está exibido o resultado do ensaio de granulometria realizado após o carregamento, onde percebe-se que não houve alteração significativa da composição granulométrica quando se compara com todos os demais ensaios realizados (corroborando o objetivo de preservar ao máximo a estrutura da amostra e garantir o mesmo arranjo em todas as séries de carregamento). 


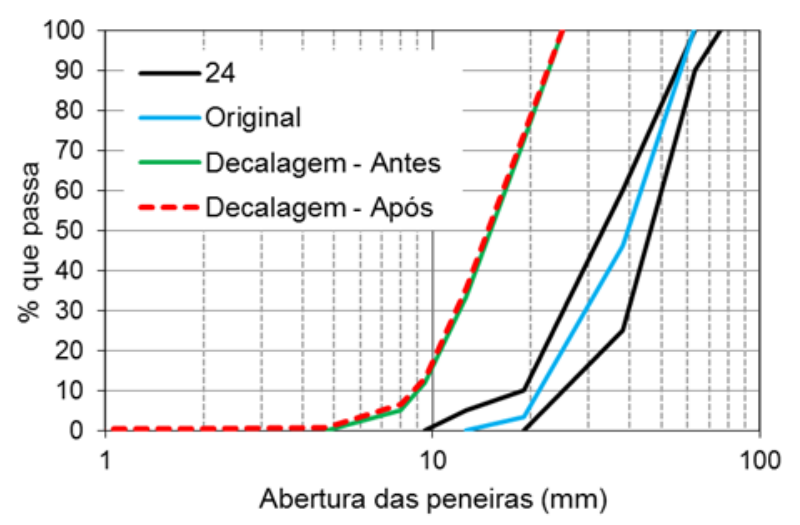

Figura 80 - Distribuição granulométrica da amostra PE XI

Por fim, vale ressaltar que qualquer que seja a associação entre ensaios laboratoriais, como no caso dos realizados por esta pesquisa, com as condições reais de vias férreas, é necessária a correta calibração campo-laboratório, com o objetivo de se analisar a resposta mecânica da via permanente. Com maior número de análises in situ, é possível se estabelecer uma correlação adequada entre o número de ciclos aplicados e a quantidade de carga transportada em uma dada ferrovia, a fim de se fazer uma análise para prever os ciclos de manutenção da via. Um exemplo disso é a simulação dos ciclos de correção geométrica na linha principal, estabelecendo-se faixas de intervenção relativas a defeitos verticais (recalques), permitindo a comparação de diferentes lastros, com diferentes granulometrias empregadas em ferrovias. Isto poderia proporcionar melhores correlações e a correta simulação das condições de campo, em laboratório. 


\section{CONCLUSÕES}

O comportamento elasto-plástico do material de lastro foi explorado por meio de ensaios triaxiais cíclicos, proporcionando uma visão sobre as características de deformação destes materiais sob um grande número de ciclos que simulam passagens de trem.

Neste trabalho, foi apresentado o desenvolvimento de um equipamento triaxial de grande escala para estudo de material de lastro ferroviário, capaz de testar com representatividade amostras com tamanho máximo de agregado de até $63 \mathrm{~mm}$. Este equipamento é inédito no Brasil e apresenta uma nova alternativa em pesquisas de lastro de ferrovias.

O método de preparação do corpo de prova mostrou-se satisfatório, pois os resultados obtidos no ensaio estão de acordo com a bibliografia pesquisada. Os ensaios de grande escala mostram boas correlações com o comportamento mecânico da camada de lastro. O nível de tensões escolhido mostrou-se satisfatório para simular a via permanente sob carregamento de trens de carga, como pôde ser visto pela deterioração dos agregados ao final do teste. Este equipamento permite a análise de diferentes materiais e granulometrias para lastros empregados em ferrovias.

Considerou-se válida a técnica de redução de granulometria do material, ou decalagem da curva granulométrica, para menores dimensões, apesar da diferença de resultados com o de grande escala. Boas correlações podem ser extraídas entre amostras de pequena e grande escala, considerando-se que ambas apresentaram a mesma forma de comportamento mecânico. Esta técnica facilita a execução de ensaios, porém pode ser menos representativa, visto que possíveis alterações nas propriedades dos agregados menores (como forma e resistência) em ensaios pequena escala podem ter efeito muito significativo no comportamento mecânico do conjunto, diferentemente da situação em grande escala.

Uma das causas para não se ter uma rigidez similar entre amostras em pequena e grande escala é o fato destas terem forma dos grãos diferentes entre si e, assim, os corpos de prova em escala reduzida tendem a ter melhor intertravamento (maior 
resistência), devido à maior quantidade de agregados cúbicos. Tal efeito também é percebido pela diferença entre massa especifica $\left(\gamma_{n}\right)$, índice de vazios $(e)$ e porosidade $(n)$ das amostras em grande e pequena escalas. Com maior resistência ao cisalhamento adquirida nos ensaios decalados, não se conseguiu obter nível de compactação similar às amostras maiores, com o risco de haver desgaste dos agregados, caso fosse empregado um esforço de vibração maior.

A resistência dos agregados é um fator que também caracteriza diferença de resultados entre amostras de diferentes tamanhos. Quanto maior for o agregado, menor será sua capacidade de resistir aos esforços, portanto a probabilidade de quebra se eleva com um aumento no tamanho dos grãos. Este fato já foi tratado em outras pesquisas e está relacionado, em alguns casos, com o processo de britagem pelo qual os diferentes agregados foram originados. Processos de britagem diferentes podem gerar variações na microestrutura do material, mesmo provenientes de rochas de mesma origem mineralógica. Assim, quando as tensões são suficientes para quebrar o material, como no caso de ferrovias, diferenças nas características dos agregados influenciam o comportamento mecânico, o que significa que a diminuição do tamanho dos mesmos alterará o comportamento do conjunto.

Outro fator que justifica a diferença de rigidez entre amostras de diferentes tamanhos é a quantidade de pontos de contatos entre agregados, onde os menores proporcionam maior número de pontos de contato entre si, e com isto, amostras constituídas com estes tendem a ser mais resistentes, quando comparadas às amostras compostas por agregados maiores, pois os esforços são mais bem distribuídos.

O estudo da decalagem em amostra contaminada em pequena escala não resultou em resultados satisfatórios, pois houve um aumento de rigidez, o que acarretou em menor deformação permanente axial e maior valor de módulo de resiliência, quando comparado às amostras limpas. Isto está relacionado ao preenchimento dos vazios pelo material contaminante, ocasionando um enrijecimento ainda maior deste corpo de prova, que já era mais rígido, mesmo na situação sem contaminação. Tal situação evidencia que o estudo da contaminação em amostras em pequena escala fica comprometido devido às condições físicas do corpo de prova. 
Estes fatores sempre serão um ponto negativo para ensaios em escala reduzida, entretanto os resultados dos testes cíclicos mostrados neste estudo demonstram que a obtenção de resultados de qualidade é possível neste caso, uma vez que se verificou que a técnica da graduação paralela funcionou satisfatoriamente, com certas limitações. Caso todas as características físicas forem garantidas entre as amostras, poderão existir curvas de graduação paralelas que representem equivalentemente os materiais utilizados nas camadas de lastro e, assim, ter-se-ia um fator de escala, que deveria ser ajustado com uma quantidade mínima de ensaios. Deste modo, poderiam ser obtidas boas correlações entre amostras em escalas reduzida e em tamanho real, por apresentarem comportamento mecânico similar.

Pelos ensaios mecânicos em grande escala apresentados, percebeu-se que um material livre de contaminação possui uma taxa de deformação mais baixa ao final dos ciclos de carregamento que aquele em condição contaminada, onde fica claro que um material contaminado está susceptível a maiores recalques. A predisposição de maiores deformações do material contaminado está relacionada à perda de resistência ao cisalhamento, ocasionada pela diminuição do intertravamento entre os agregados. Este fenômeno se agrava proporcionalmente à quantidade de material incrustante, chegando ao ponto da matriz final do conjunto ser mais representada pelo comportamento dos finos.

Além disso, a degradação da amostra contaminada foi mais acentuada que aquela sem finos, demonstrando que o aumento nos níveis de colmatação implica em perda da durabilidade do lastro, acarretando em necessidade de mais ciclos de manutenção para sua correção geométrica e em diminuição de sua vida útil.

A análise do impacto da contaminação também foi observada em amostras de escala reduzida, tanto em situação seca quanto úmida, o que corresponderia a um lastro colmatado e saturado. Com a adição de água ao material contaminado, percebeu-se que as deformações mais que duplicaram, ficando claramente evidenciada a mudança no comportamento mecânico do lastro em tal condição. Com relação ao módulo de resiliência do material contaminado em comparação com aquele em situação contaminada e saturada, percebe-se que a umidade causa uma diminuição de rigidez e, por consequência, também de módulo de resiliência. 
Como consequência da contaminação, ocorre uma aceleração no processo de deterioração na camada de lastro, que com a presença de água aumenta o processo de abrasão. Com isso, ocorre menor dissipação das tensões pelo lastro e maior transferência de esforços ao subleito, levando a maiores recalques e à criação de bolsões de lama. Tais bolsões afetam consideravelmente o alinhamento e a geometria da linha, pois acentuam o incremento dinâmico e comprometem o tráfego. De maneira geral, observou-se que a combinação de finos e água ao lastro afeta fortemente a resposta mecânica da via permanente, diminuindo sua rigidez e ocasionando instabilidade do sistema, devendo esta situação ser evitada.

A alteração da distribuição granulométrica, de uma graduação mais uniforme para uma mais densa, reduz a deformação axial permanente. A graduação AREMA 3 proporcionou menor resistência e maior taxa de deformação após a ciclagem, resultando em mais quebra em comparação com a graduação AREMA 24. Os resultados dos testes cíclicos com variação da graduação indicam que mesmo uma pequena alteração no coeficiente de uniformidade $\left(C_{u}\right)$ afeta diretamente 0 comportamento elásto-plástico do lastro.

A diferença entre as granulometrias, no que se refere à degradação, tende a ser mais elevada à medida que o número de ciclos e o nível de carregamento aumentam. Com isto, a degradação conduz a menores tamanhos de agregados e valores de angularidade, por conseguinte a resistência ao cisalhamento e a capacidade de drenagem da camada de lastro diminuem.

Curvas bem graduadas proporcionam melhor intertravamento dos agregados e composições mais densas (maior estado de compactação), acarretando em menor deformação. Entretanto, como a maioria das especificações de lastro exigem graduações uniformes, a fim de permitir a drenagem livre, deve-se existir determinada graduação de lastro que garanta adequada estabilidade, sem causar significativo comprometimento à drenagem.

Verificou-se que os materiais granulares revelam uma forte tendência para se compactarem sob níveis elevados de tensão, causando um aumento significativo na sua resistência e rigidez. Quanto mais denso for o lastro, maior será o seu módulo de resiliência. Dentro deste contexto, os resultados mostram que o aumento da 
amplitude de confinamento é benéfico para minimizar deformações elásticas e permanentes do lastro.

O lastro, como mostrado neste estudo, quando submetido a tensões mais elevadas apresenta acúmulo de deformação permanente que pode levar a estrutura ao colapso ou a condições ruins de utilização. O aumento de carga transportada por eixo contribui para uma degradação acelerada dos componentes da via, ocasionando a diminuição do período entre ciclos de manutenção. O efeito deste acréscimo de tensão para a via foi observado através da comparação entre as deformações ocorridas para diferentes níveis de tensão aplicados, e com isto, verificou-se a influência do aumento de carga nos ciclos de manutenção.

Com a aplicação de dois tipos de carregamento, observou-se a influência das condições de carga para o comportamento deformacional do material. O estado de tensão no lastro decorre das condições de cada local de uma via permanente, portanto a resposta às deformações pode ser diferente ao longo de sua trajetória. Diferentes condições da subestrutura alteram as repostas mecânicas e, assim, a interação entre os componentes. Entretanto, é importante realizar uma série de medições in situ, tanto de deformações quanto de tensões para se chegar ao modelo de carregamento similar às condições de operação de uma determinada ferrovia. A dificuldade de se definir as tensões que atuam nas camadas granulares é um fator importante, configurando um cenário rico para aprofundamento de inúmeras pesquisas. Destaca-se ainda como tema para ser estudado, a alteração com o tempo do contato entre os componentes como, por exemplo, dormente e lastro, pois a maneira como ocorre a transmissão de tensões entre estes elementos ainda não é completamente compreendida.

Pelos resultados satisfatórios demonstrados, de alguma forma o estudo realizado, serve como base bibliográfica para se entender as características do lastro ferroviário em condições de carga variadas, por meio da determinação da influência dos diversos parâmetros que afetam o comportamento deste material. As conclusões retiradas a partir desta pesquisa têm o intuito de contribuir para um projeto de vias férreas mais eficientes, pois ao se minimizar a deformação e a degradação da camada de lastro, permite-se o nivelamento adequado da via 
permanente por mais tempo e, consequentemente, reduzindo os custos de manutenção.

Finalmente, o propósito deste trabalho foi 0 de proporcionar uma melhor compreensão deste tema complexo para trazer uma melhoria no projeto e na manutenção da subestrutura da via, com a adoção de uma tecnologia de ponta, de forma a minimizar custos e promover vias de alta confiabilidade. Espera-se que o assunto gere mais interesse entre os pesquisadores e engenheiros no campo da geotecnia voltada às linhas férreas e auxilie no desenvolvimento ferroviário nacional. 


\section{REFERÊNCIAS}

AASHTO T 292. Interim method of test for resilient modulus of subgrade soils and untreated base/subbase materials. American Association of State Highway and Transportation Officials, Washington, D.C., 1991.

ABNT NBR 5564. Via férrea - Lastro ferroviário - Requisitos e métodos de ensaios. Associação Brasileira de Normas Técnicas, Rio de Janeiro, 2011.

ABNT NBR NM 45. Agregados - Determinação da massa unitária e do volume de vazios. Associação Brasileira de Normas Técnicas, Rio de Janeiro, 2006.

ABNT NBR NM 46. Agregados - Determinação do material fino que passa através da peneira $75 \mathrm{~mm}$, por lavagem. Associação Brasileira de Normas Técnicas, Rio de Janeiro, 2003.

ABNT NBR NM 51. Agregado graúdo - Ensaio de abrasão "Los Angeles". Associação Brasileira de Normas Técnicas, Rio de Janeiro, 2001.

ALVA-HURTADO, J. E., SELIG, E. T. Permanent strain behavior of railway ballast. Proceedings of 10th International Conference on Soil Mechanics and Foundation Engineering. Pergamon Press: New York, 543-546, 1981.

ALVA-HURTADO, J. E., MCMAHON, D. R., SteWART, H. E. Apparatus and techniques for static triaxial testing of ballast. Laboratory Shear Strength of Soil, ASTM STP 740, R.N. Yong and F.C. Townsend, EDS., American Society for Testing and Materials, 1981, pp.94-113.

ALVA-HURTADO, J.E. A methodology to predict the elastic and inelastic behavior of railroad ballast. PhD Dissertation, Report No. OUR80-240D, Department of Civil Engineering, University of Massachusetts, Amherst, Massachusetts, 1980.

ALVES, G. K. A., SINAY, M. C. F. Os dormentes ferroviários, seus tratamentos e o meio ambiente. [2005]. Disponível em: <http://www.cbtu.gov.br/estudos/pesquisa >. Acesso em:13/06/2012. 
ANDERSON, J. S., ROSE, J. G. In-Situ Test Measurement Techniques Within Railway Track Structures. University of Kentucky, Lexington, KY, 2008. Disponível em: <http://www.engr.uky.edu/>. Acesso em: 10/05/2012.

ANDERSON, W. F., FAIR, P. Behavior of railroad ballast under monotonic and cyclic loading. Journal of Geotechnical and Geoenvironmental Engineering, Vol. 134, No. 3, 2008.

ANDERSON, W.F, KEY, J. A. Model Testing of Two-Layer Railway Track Ballast. Journal of Geotechnical and Geoenvironmental Engineering, ASCE, Vol. 126, No. 4, 2000, pp 317-323.

ARAÚJO, M. P. Infraestrutura de transporte e desenvolvimento regional: uma abordagem de equilíbrio geral inter-regional. Tese (Doutorado em Economia Aplicada) - Universidade de São Paulo, Piracicaba, 2006.

AREMA. Manual for Railway Engineering. American Railway Engineering, 2009.

AS 2758.7. Aggregates and rock for engineering purposes, Part 7: Railway ballast, 1996.

ASTM C 117. Standard test method for materials finer than $75 \mathrm{~mm}$ (No. 200) sieve in mineral aggregates by washing, 2004.

ASTM C 127. Standard test method for density, relative density (specific gravity), and absorption of coarse aggregate, 2007.

ASTM C 136. Standard Test Method for sieve analysis of fine and coarse aggregates, 2006.

ASTM C 142. Standard Test Method for clay lumps and friable particles in agregates, 2004.

ASTM C 535-09. Standard Test Method for Resistance to Degradation for Small-Size Coarse Aggregate by Abrasion and Impact in the Los Angeles Machine, 2009.

ASTM C 702. Standard Practice for Reducing Samples of Aggregate to Testing Size. American Society for Testing and Materials, ASTM, 2003. 
ASTM C 88-05. Standard test method for soundness of aggregate by use of sodium sulfate or magnesium sulfate, 2005.

ASTM D 4791. Standard Test Method for flat particles, elongated particles, or flat and elongated particles in coarse aggregate. American Society for Testing and Materials, ASTM, 2010.

ASTM D 5311. Standard Test Method for load controlled cyclic triaxial strength of soil. American Society for Testing and Materials, 2004.

ASTM E11 Standard Specification for Woven Wire Test Sieve Cloth and Test Sieves. American Society for Testing and Materials, ASTM, 2009.

ATALAR, C., DAS, B.M., SHIN, E.C., KIM, D.H. Settlement of geogrid-reinforced railroad bed due to cyclic load. Proc. 15th International Conference on Soil Mechanics and Geotechnical Engineering, Istanbul, Vol. 3, 2001, pp. 2045-2048.

AURSUDKIJ, B., MCDOWELL, G. R., COLLOP, A. C. Cyclic Loading of Railway Ballast under Triaxial Condition in a railway test facility. In: Granular Matter, Vol. 11, No. 6, 2009, pp.391-401.

AURSUDKIJ, B. A Laboratory Study of Railway Ballast Behaviour under Traffic Loading and Tamping Maintenance. Thesis, The University of Nottingham, United Kingdom, 2007.

BATHURST, L. A., KERR, A. D. An improved analysis for the determination of required ballast depth. Proceedings, American Railway Engineering and Maintenance of Way Association, 1995, pp. 916-947.

BATHURST, R.J. AND RAYMOND, G.P.: Geogrid reinforcement of ballasted track. Transportation Research Record, TRB, Vol. 1153, 1987, pp. 8-14.

BAUMGARTNER, J.P. Prices and Costs in The Railway Sector, École Polytechnique Fédérale de Lausanne, 2001. 17p.

BERNUCCI, L. B., MOTTA, L. M. G., CERATTI, J. A. P., SOARES, J. B. Pavimentação Asfáltica. Formação básica para engenheiros. Rio de Janeiro: Petrobrás, ABEDA, 2007. 501p. 
BISHOP, A. W., GREEN, G. E. The influence of end restraint on the compression strength of a cohesionless Soil. Geotechnique15, 1965, pp. 243-266.

CAMBIO, D., GE, L. Effects of Parallel Gradation on Strength Properties of Ballast Materials. Advances in Measurement and Modeling of Soil Behavior, 2007.

COCUNATO, J. M. Estudo da Contaminação do Lastro Ferroviário e o uso de Geossintéticos no Controle do Fenômeno. Dissertação, Universidade Federal do Rio de Janeiro, 1998.

COLLINS, I. F., BOULBIBANE, M. Geomechanical Analysis of Unbound Pavements Based on Shakedown Theory. Journal of Geotechnical and Geoenviromental Engineering, Vol. 126, No. 1, 2000, p 50-59.

DIYALJEE, V. A. Effects of stress history on ballast deformation. Journal of the Geotechnical Engineering, ASCE, Vol. 113, No. 8, 1987, pp. 909-914.

EBRAHIMI, A. Mechanistic Behavior of Railroad Ballast, Preliminary Defense, University of Wisconsin-Madison, WI, 2010.

EBRAHIMI, A; TINJUM, J. M.; EDIL, T. B. Large-Scale, cyclic triaxial testing of rail ballast. AREMA Annual Conference e Exposition, Orlando, 2010.

EN 13450. Aggregates for Railway Ballast. European Standard - European Committee for Standardization, Brussels, 2002.

ESVELD, C. Modern railway track. MRT Productions, 2001, 654p.

FORTUNATO, E. Renovação de Plataformas Ferroviárias. Estudos Relativos à Capacidade de Carga. PhD Thesis. Porto: University of Porto. 2005.

GUASCH J. L. Logistics Costs and their Impact and Determinants in Latin America and Caribbean. The World Bank. Washington, DC. Mimeo, 2002.

HAN, X., SELIG, T. Effects of fouling on ballast settlement. 6th International Heavy Haul Conference. St Louis; Int. Heavy Haul Association; Spoornet Vol. 1, 1997, pp. 257-268.

HAY, W. W. Railroad Engineering. 2nd Edition. Wiley Interscience, 1982. 758p. 
HICKS, R. G, MONISMITH, C. L.: Factors influencing the resilient response of granular materials. Highway Research Record No. 345, 1971, pp. 15-31.

HUANG, H., TUTUMLUER, E., DOMBROW, W. Laboratory Characterization of Fouled Railroad Ballast Behavior. 88th annual Meeting of Transportation Research Board, 2009.

HVEEM, F. N., CARMANY, R. M. The factors underlying the rational design of pavements. Proc. Highway Research Board 28, Washington, DC, 1948, pp. 101-136.

HVEEM, F. N. (1955). Pavement deflections and fatigue failures. Highway Research Board Bulletin, No. 114, Washington, DC, pp. 43-87.

INDRARATNA, B., IONESCU, D., CHRISTIE, D., CHOWDHURY, R. Compression and degradation of railway ballast under one-dimensional loading. Australian Geomechanics, 1997, pp 48-61.

INDRARATNA, B., KHABBAZ, H., SALIM, W., LACKENBY, J. AND CHRISTIE, D. Ballast characteristics and the effects of geosynthetics on rail track deformation. International Conference on Geosynthetics and Geoenvironmental Engineering, Mumbai, India, 2004, pp. 3-12.

INDRARATNA, B., NIMBALKAR, S., CHRISTIE, D., RUJIKIATKAMJORN, C., VINOD, J. Field assessment of the performance of a balasted rail track with and without geosynthetics. Journal of the Geotechnical and Geoenvironmental Engineering, Vol. 136, No. 7, 2010a, pp. 907-917.

INDRARATNA, B., SALIM, W. Mechanics of ballasted rail tracks: a geotechnical perspective. Taylor \& Francis Group plc.Londres, 2005, 248 pp.

INDRARATNA, B., SALIM, W., IONESCU, D. AND CHRISTIE, D. Stress-strain and degradation behaviour of railway ballast under static and dynamic loading, based on large-scale triaxial testing. Proc. 15th International Conference on Soil Mechanics and Geotechnology Engineering, Istanbul, Vol. 3, 2001, pp. 2093-2096. 
INDRARATNA, B., THAKUR, P., VINOD, J. Experimental and Numerical Study of Railway Ballast Behavior under Cyclic Loading. International Journal of Geomechanics, Vol. 10, No. 4, 2010b, pp 136-144.

INDRARATNA, B.; IONESCU, D.; CHRISTIE. H. D. Shear Behavior of Railway ballast based on large-scale triaxial tests. Journal of Geotechnical and Geoenvironmental Engineering, Vol. 124, No. 5, 1998, p. 439-449.

INDRARATNA, B.; SALIM, W.; RUJIKIATKAMJORN, C. In: Advanced rail geotechnology ballasted track. Taylor \& Francis Group, London, UK, 2011.

INTERNATIONAL RAILWAY JOURNAL, Vol. 51, No. 12, 2011, p. 16.

IONESCU, D., INDRARATNA, B. AND CHRISTIE, H.D. Behaviour of railway ballast under dynamic loads. Proc. 13th Southeast Asian Geotechnical Conference, Taipei, 1998, pp. 69-74.

IONESCU, D. Evaluation of the engineering behaviour of railway ballast. PhD thesis, University of Wollongong, 2004.

JEFFS, T., TEW, G.P. A review of track design procedures, Vol. 2, Sleepers and Ballast, Railways of Australia, 1991.

JERNIGAN, R. L. The Physical Modeling of Soils Containing Oversized Particles. Ph.D. thesis, University of Colorado at Boulder, 1998.

JOHNSON, K. L. Plastic Flow, Residual Stresses, and Shakedown in Rolling Contact. Proc., 2nd International Conference on Contact Mechanics and Wear of Rail/Wheel Systems, University of Rhode Island, Kingston, University of Waterloo Press, Ontario, Canada, 1986.

KALCHEFF, I. V., HICKS, R.G. A test procedure for determining the resilient properties of granular materials. Journal of Testing and Evaluation, American Society for Testing Materials, Vol. 1, No. 6,pp. 472-479, November, 1973.

KERR, A. D. On the Stress Analysis of Rails and Ties. Bulletin 659, in: Proceedings of the American Railway Engineering Association, Vol. 78, 1977, pp. 19-43. 
KLINCEVICIUS, M. G. Y. Estudo de Propriedades, de Tensões e do Comportamento Mecânico de Lastros Ferroviários. Dissertação, Escola Politécnica da Universidade de São Paulo, São Paulo, 2011.

LACKENBY, J., INDRARATNA, B., KHABBAZ, H. The effect of particle size distribution and compaction on ballast degradation. Technical Report No. 4, RAILCRC Project No. 6, University of Wollongong, Australia, 2003.

LACKENBY, J.; INDRARATNA, B.; MCDOWELL, G.; CHRISTIE, D. Effect of confining pressure on ballast degradation and under cyclic triaxial loading. In: Géotechnique 57, №. 6, 2007, pp. 527-536.

LAMBE, T.W., WHITMAN, R.V. Soil Mechanics - New York: John Willey \& Sons, 1969. 553 p.

LEKARP, F., ISACSSON, U. AND DAWSON, A. State of the art I: Resilient response of unbound aggregates. Journal of Transportation Engineering, ASCE. Vol. 126, No.1, 2000, pp. 66-75.

LIM, W. L. Mechanics of Railway Ballast Behaviour. PhD Thesis. University of Nottingham. 2004, 216 p.

LOWE, J. Shear strength of coarse embankment dam materials. In: Huitième congress des grands barrages, Èdimbourg, pp.745-761, 1964.

MALYSZ, R. Desenvolvimento de um equipamento triaxial de grande porte para a avaliação de agregados utilizados como camada de pavimentos. 2009. 350p. Tese (Doutorado) - Programa de Pós-graduação em Engenharia Civil, Universidade Federal do Rio Grande do Sul. Porto Alegre, 2009.

MORGAN, J. R. The response of granular materials to repeated loading Proceedings, Third Conference of the Australian Road Research Board, pp. 11781192, Sydney, Australia, 1966.

MUNIZ DA SILVA, L. F. Fundamentos teórico-experimentais da mecânica dos pavimentos ferroviários e esboço de um sistema de gerência aplicado à manutenção 
da via permanente. Tese de doutorado. Universidade Federal do Rio de Janeiro. Rio de Janeiro. 2002. 347 pp.

NALSUND, R. Effect of grading on degradation of crushed-rock Railway Ballastand on Permanent Axial Deformation. Transportation Research Record, Washington, D. C., No. 2154, 2010, p.149-155.

SOUSA PINTO, C. Curso básico de mecânica dos solos em 16 aulas. 3a Edição, São Paulo: Oficina de Textos, 2000. 247 p.

PLANO NACIONAL DE LOGística E TRANSPORTES (PNLT). Projeto de Reavaliação de Estimativas e Metas do PNLT, 2012. 260p.

PLANO NACIONAL DE LOGÍSTICA E TRANSPORTES (PNLT). Relatório executivo, 2009. 100p.

PROFILLIDIS, V.A. Railway Management and Engineering. Avebury Technical, Ashgate Publishing Ltd, UK, 2006.

RAYMOND, G. P., DIYALJEE, V. A. Railroad ballast sizing and grading. Journal of Geotechnical Engineering, ASCE, 105(5), 676-681, 1979.

RAYMOND, G.P., DAVIES, J.R. Triaxial tests on dolomite railroad ballast. Journal of Geotechnical Engineering, ASCE, Vol. 104, No. GT6, pp. 737-751,1978.

RAYMOND, G.P., WILLIAMS, D.R. Repeated load triaxial tests on dolomite ballast. Journal of the Geotechnical Engineering Division, ASCE, Vol. 104 (GT 7), 1978, pp. 1013-1029.

RAYMOND, G.P. Research on railroad ballast specification and evaluation. Transportation Research Record 1006, TRB, 1985, pp. 1-8.

SEED, H. B., CHAN, C. K., LEE, C. E. Resilience characteristics subgrade soils and their relation to fatigue failures. Proc. Int. Conf. Structural Design of Asphalt Pavements, Ann Abor, Michigan, 1962. pp. 611-636. 
SEKINE, E.; KONO, A.; KITO, A. Strength and deformation characteristics of railroad ballast in ballast particle abrasion process. Railway Technical Research Institute, Japanese National Railways, Vol. 46, pp 256-261, 2005.

SELIG, E. T., ALVA-HURTADO, J. E. Predicting effects of repeated wheel loading on track settlement. Proceeding of the 2nd International Heavy Haul Conference, Colorado Springs, 1982. pp. 476-487.

SELIG, E. T., WATERS, J. M. Track geotechnology and substructures Management. Thomas Telford Services Ltd., Londres, 1994. 446 pp.

SELIG, E. T. Soil measurement using inductance coil method, ASTM-STP584. Performance Monitoring for Geotechnical Costruction, 1975. Pp. 141-158.

SELIG, E. T. Fast substructure dynamic stresses, strains and deflections from 3 to 300 MGT. Report No. TSC80-270I, Department of Civil Engineering, University of Massachusetts, Amhert, Massachusetts prepared for U.S. DOT, Transportation Systems Center, Cambridge, Massachusetts, 1980.

SEVI, A. S. Physical modelling of railroad ballast using parallel gradation scaling technique within the cyclical triaxial framework. Tese de doutorado. Missouri University of science and Technology. 2008. 137p.

SEVI, A. S.; GE, L.; TAKE, W. A. A large-scale triaxial apparatus for prototype railroad ballast testing. Geotechnical testing journal, Vol. 32, No. 4, 2009, pp.1- 8.

SHENTON, M.J. Deformation of railway ballast under repeated loading conditions. In: Kerr (ed.): Railroad Track Mechanics and Technology. Proc. of a symposium held at Princeton Univ., 1975, pp. 387-404.

SKOGLUND, K. A. A study of Some Factors in Mechanistic Railway Track Design, Ph.D. dissertation, Norwegian University of Science and Technology, 2002.

SOUZA, V. H. P. Dos grandes projetos de desenvolvimento aos projetos pontuais no Brasil e a influência do modal rodoviário. Revista Geografia e Pesquisa, Ourinhos, 2009. 
SPADA, J. L. G. Uma Abordagem de Mecânica dos Pavimentos Aplicada ao Entendimento do Mecanismo de Comportamento Tensão-Deformação da Via Férrea. Tese de doutorado. Universidade Federal do Rio de Janeiro. Rio de Janeiro. 2003. $251 \mathrm{pp}$.

STEWART, H.E. Permanent strains from cyclic variable amplitude loadings. J. of Geotechnical Engineering, ASCE, Vol. 112, No. 6, 1986, pp. 646-660.

SUIKER, A. S. J. The mechanical behavior of ballasted railway tracks. Dissertation, Delft University of Technology. Netherlands, 2002.

SUIKER, A. S. J.; SELIG, E. T.; FRENKEL, R. Static and cyclic triaxial testing of ballast and subballast. Journal of Geotechnical and Geoenvironmental Engineering, Vol. 131, No. 6, 2005.

TALBOT, A. N. Second progress report of the Special Committee on Stresses in Railroad Track. Proceedings of the AREA, Vol. 21, 1920, pp. 645-814.

VARADARAJAN, A., SHARMA, K.G., VENKATACHALAM, K., AND GUPTA, A.K. Testing and modeling two rockfill materials. Journal of Geotechnical and Geoenvironmental Engineering, ASCE, 129(3), 2003, p 206-218.

WERKMEISTER, S., DAWSON, A. R., WELLNER, F. Permanent Deformation Behavior of Granular Materials and the Shakedown Concept, Transportation Research Record, Washington, D. C., No. 1757, 2001, p.75-81.

WHEAT, P., SMITH, A. Assessing the marginal infrastructure maintenance wear and tear costs of Britain's railway network. Journal of Transport Economics and Policy, Vol. 42, 2008, pp. 189-224.

WRIGHT, S. E. Damage caused to ballast by mechanical maintenance techniques. British Rail Research Technical Memorandum TM TD 15, May 1983.

YANG, L. A., POWRIE, W., J. A. PRIEST. Dynamic Stress Analysis of a Ballasted Railway Track Bed during Train Passage. Journal of Geotechnical and Geoenvironmental Engineering, ASCE, Vol. 135, No. 5, 2009, pp,680-689. 